\title{
Representation of Regional Urban Development Conditions Using a Watershed-Based Gradient Study Design
}

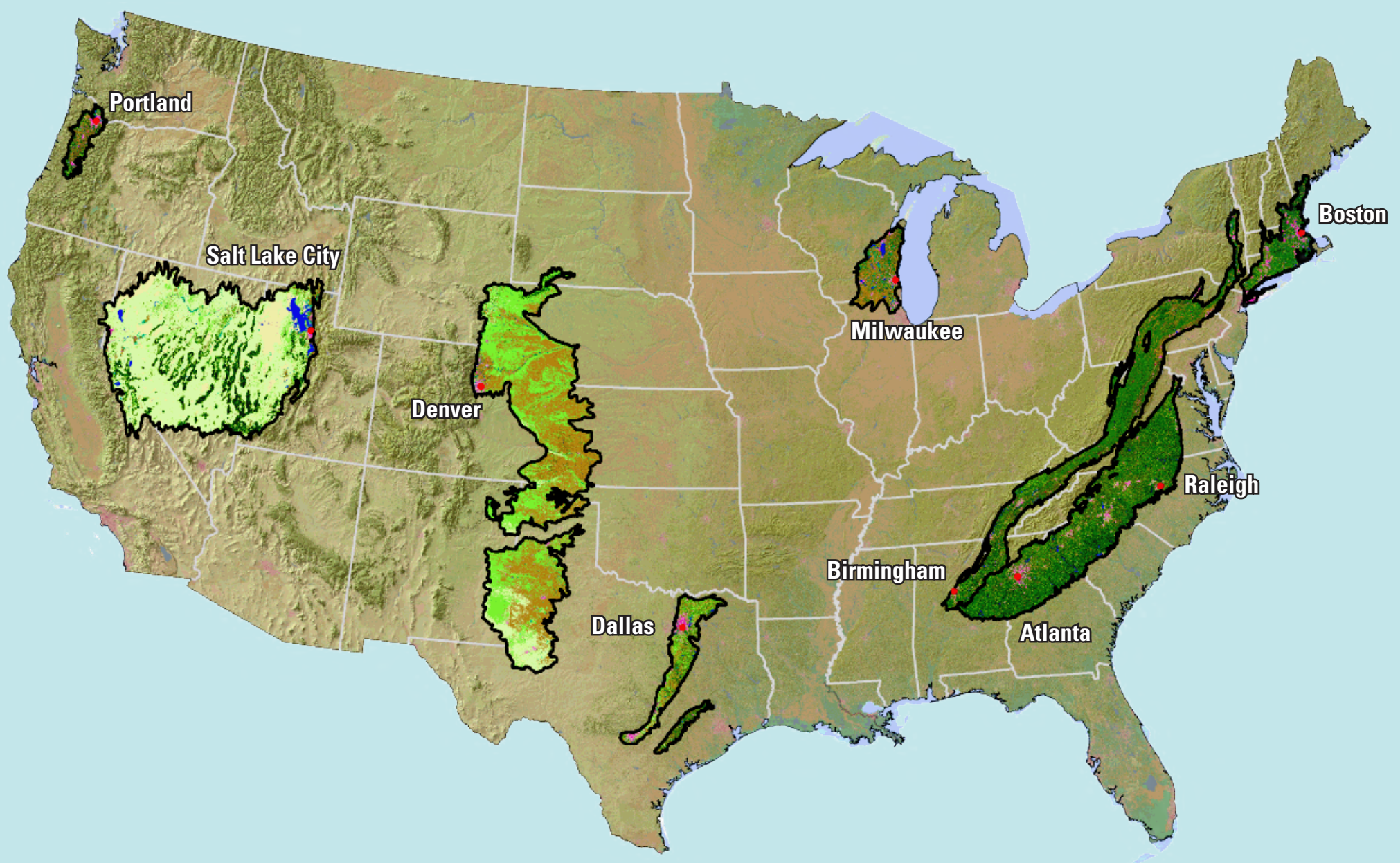

Scientific Investigations Report 2012-5070 



\section{Representation of Regional Urban Development Conditions Using a Watershed-Based Gradient Study Design}

By Silvia Terziotti, Gerard McMahon, and Amanda H. Bell

National Water-Quality Assessment Program

Scientific Investigations Report 2012-5070 


\title{
U.S. Department of the Interior \\ KEN SALAZAR, Secretary \\ U.S. Geological Survey \\ Marcia K. McNutt, Director
}

\author{
U.S. Geological Survey, Reston, Virginia: 2012
}

For more information on the USGS - the Federal source for science about the Earth, its natural and living resources, natural hazards, and the environment, visit http://Www.usgs.gov or call 1-888-ASK-USGS.

For an overview of USGS information products, including maps, imagery, and publications, visit $h t t p: / / w w w . u s g s . g o v / p u b p r o d$

To order this and other USGS information products, visit http://store.usgs.gov

Any use of trade, product, or firm names is for descriptive purposes only and does not imply endorsement by the U.S. Government.

Although this report is in the public domain, permission must be secured from the individual copyright owners to reproduce any copyrighted materials contained within this report.

Suggested citation:

Terziotti, Silvia, McMahon, Gerard, BCEBell, A.H., 2012, Representation of regional urban development conditions using a watershed-based gradient study design: U.S. Geological Survey Scientific Investigations Report 2012-5070, $109 \mathrm{p}$.

(Available only online at http://pubs.usgs.gov/sir/2012/5070/ 


\section{Foreword}

The U.S. Geological Survey (USGS) is committed to providing the Nation with reliable scientific information that helps to enhance and protect the overall quality of life and that facilitates effective management of water, biological, energy, and mineral resources (http://www.usgs.gov/. Information on the Nation's water resources is critical to ensuring long-term availability of water that is safe for drinking and recreation and is suitable for industry, irrigation, and fish and wildlife. Population growth and increasing demands for water make the availability of that water, measured in terms of quantity and quality, even more essential to the long-term sustainability of our communities and ecosystems.

The USGS implemented the National Water-Quality Assessment (NAWQA) Program in 1991 to support national, regional, State, and local information needs and decisions related to water-quality management and policy (http://water.usgs.gov/nawqa). The NAWQA Program is designed to answer: What is the quality of our Nation's streams and groundwater? How are conditions changing over time? How do natural features and human activities affect the quality of streams and groundwater, and where are those effects most pronounced? By combining information on water chemistry, physical characteristics, stream habitat, and aquatic life, the NAWQA Program aims to provide science-based insights for current and emerging water issues and priorities. From 1991 to 2001, the NAWQA Program completed interdisciplinary assessments and established a baseline understanding of water-quality conditions in 51 of the Nation's river basins and aquifers, referred to as Study Units (http://water.usgs.gov/nawqa/studies/study_units.html.

National and regional assessments are ongoing in the second decade (2001-2012) of the NAWQA Program as 42 of the 51 Study Units are selectively reassessed. These assessments extend the findings in the Study Units by determining water-quality status and trends at sites that have been consistently monitored for more than a decade, and filling critical gaps in characterizing the quality of surface water and groundwater. For example, increased emphasis has been placed on assessing the quality of source water and finished water associated with many of the Nation's largest community water systems. During the second decade, NAWQA is addressing five national priority topics that build an understanding of how natural features and human activities affect water quality, and establish links between sources of contaminants, the transport of those contaminants through the hydrologic system, and the potential effects of contaminants on humans and aquatic ecosystems. Included are studies on the fate of agricultural chemicals, effects of urbanization on stream ecosystems, bioaccumulation of mercury in stream ecosystems, effects of nutrient enrichment on aquatic ecosystems, and transport of contaminants to public-supply wells. In addition, national syntheses of information on pesticides, volatile organic compounds (VOCs), nutrients, trace elements, and aquatic ecology are continuing.

The USGS aims to disseminate credible, timely, and relevant science information to address practical and effective water-resource management and strategies that protect and restore water quality. We hope this NAWQA publication will provide you with insights and information to meet your needs, and will foster increased citizen awareness and involvement in the protection and restoration of our Nation's waters.

The USGS recognizes that a national assessment by a single program cannot address all water-resource issues of interest. External coordination at all levels is critical for cost-effective management, regulation, and conservation of our Nation's water resources. The NAWQA Program, therefore, depends on advice and information from other agencies—Federal, State, regional, interstate, Tribal, and local—as well as nongovernmental organizations, industry, academia, and other stakeholder groups. Your assistance and suggestions are greatly appreciated.

William H. Werkheiser

USGS Associate Director for Water 



\section{Contents}

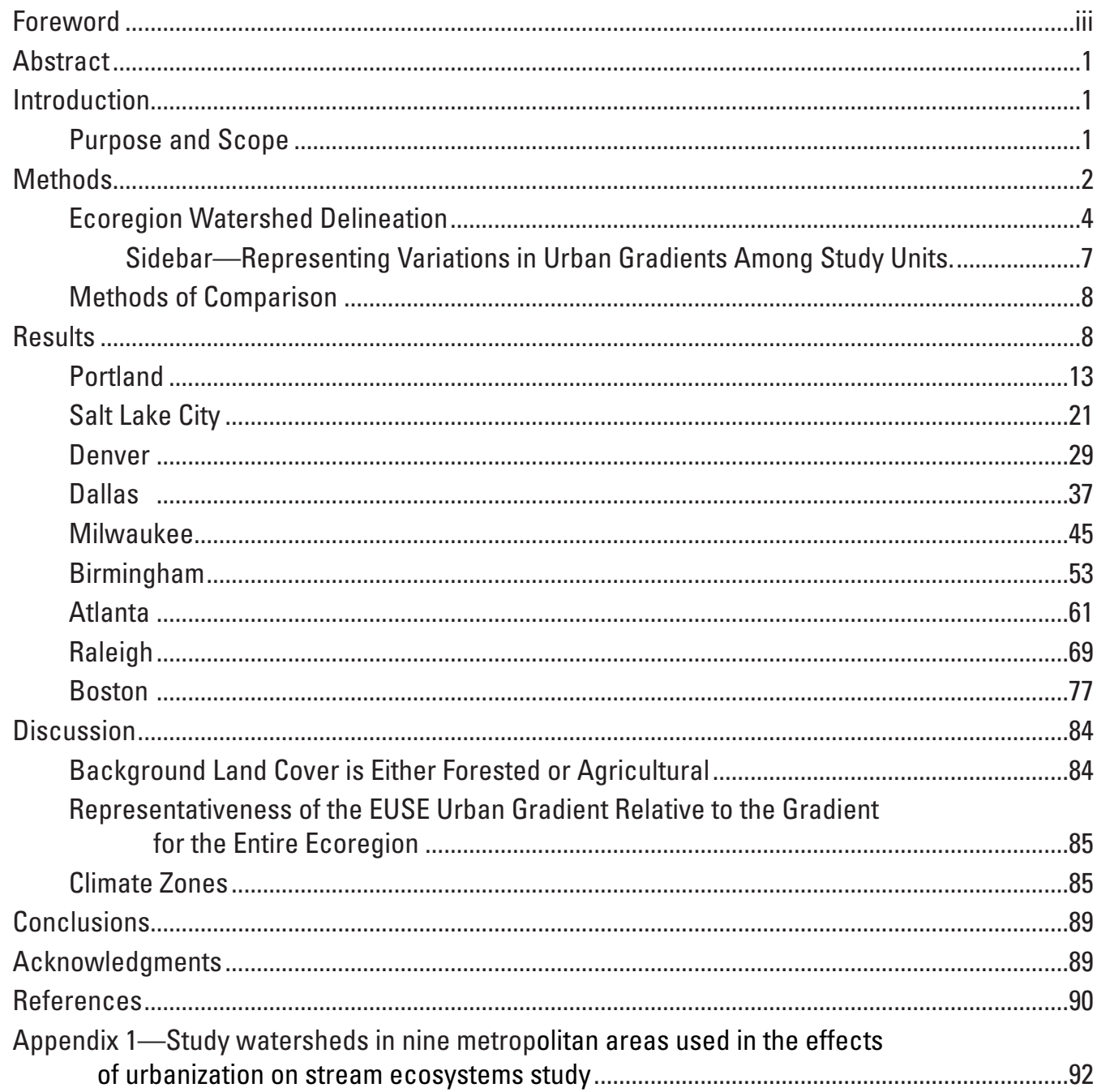

\section{Figures}

1. Map showing effects of urbanization on stream ecosystems (EUSE) study areas and associated U.S. Environmental Protection Agency Level III ecoregions...................2

2. Map showing NHDPlus nested catchment areas, Raleigh, North Carolina, metropolitan area.

.5

3. Maps showing examples of aggregated NHDPlus watersheds used for analysis of basin characteristics.

4. Graphs showing summary of Willamette Valley Level III ecoregion and Portland EUSE watershed characteristics ...........................................................................14

5. Map summary of Willamette Valley Level III ecoregion watershed characteristics......15

6. Graphs showing summary of Willamette Valley Level III ecoregion and Portland EUSE study watershed characteristics by percentage of urban development class.....19 
7. Cumulative distribution plot of the percentage of urban development, forested, and agricultural land cover in the Willamette Valley Level III ecoregion watersheds, and the percentage of the same land-cover types in the Portland EUSE study watersheds

8. Graphs showing summary of Central Basin and Range Level III ecoregion and Salt Lake City EUSE study watershed characteristics.

9. Map summary of Central Basin and Range Level III ecoregion watershed characteristics

10. Graphs showing summary of Central Basin and Range Level III ecoregion and Salt Lake City EUSE study watershed characteristics by percentage of urban development class.

11. Cumulative distribution plot of the percentage of urban development, forested, and agricultural land cover in the Central Basin and Range Level III ecoregion watersheds, and the percentage of the same land-cover types in the Salt Lake City EUSE study watersheds

12. Graphs showing summary of High Plains Level III ecoregion and Denver EUSE study watershed characteristics.

13. Map summary of High Plains Level III ecoregion watershed characteristics.

14. Graphs showing summary of High Plains Level III ecoregion and Denver EUSE study watershed characteristics by percentage of urban development class

15. Cumulative distribution plot of the percentage of urban development, forested, and agricultural land cover in the High Plains Level III ecoregion watersheds, and the percentage of the same land-cover types in the Denver EUSE study watersheds..........36

16. Graphs showing summary of Texas Blackland Prairie Level III ecoregion and Dallas EUSE study watershed characteristics

17. Map summary of Texas Blackland Prairie Level III ecoregion watershed characteristics

18. Graphs showing summary of Blackland Prairie Level III ecoregion and Dallas EUSE study watershed characteristics by percentage of urban development class

19. Cumulative distribution plot of the percentage of urban development, forested, and agricultural land cover in the Texas Blackland Prairie Level III ecoregion watersheds, and the percentage of the same land-cover types in the Dallas EUSE study watersheds

20. Graphs showing summary of Southeastern Wisconsin Till Plains Level III ecoregion and Milwaukee EUSE study watershed characteristics.

21. Map summary of Southeastern Wisconsin Till Plains Level III ecoregion watershed characteristics

22. Graphs showing summary of Southeastern Wisconsin Till Plains Level III ecoregion and Milwaukee EUSE study watershed characteristics by percentage of urban development class.

23. Cumulative distribution plot of the percentage of urban development, forested, and agricultural land cover in the Southeastern Wisconsin Till Plains Level III ecoregion watersheds, and the percentage of the same land-cover types in the Milwaukee EUSE study watersheds 
24. Graphs showing summary of Ridge and Valley Level III ecoregion and Birmingham EUSE study watershed characteristics.

25. Map summary of Ridge and Valley Level III ecoregion watershed characteristics .......55

26. Graphs showing summary of Ridge and Valley Level III ecoregion and Birmingham EUSE study watershed characteristics by percentage of urban development class.....59

27. Cumulative distribution plot of the percentage of urban development, forested, and agricultural land cover in the Ridge and Valley Level III ecoregion watersheds, and the percentage of the same land-cover types in the Birmingham EUSE study watersheds.

28. Graphs showing summary of Piedmont Level III ecoregion and Atlanta EUSE study watershed characteristics

29. Map summary of Piedmont Level III ecoregion watershed characteristics in the vicinity of Atlanta

30. Graphs showing summary of Piedmont Level III ecoregion and Atlanta EUSE study watershed characteristics by percentage of urban development class.

31. Cumulative distribution plot of the percentage of urban development, forested, and agricultural land cover in the Piedmont Level III ecoregion watersheds, and the percentage of the same land-cover types in the Atlanta EUSE study watersheds.........68

32. Graphs showing summary of Piedmont Level III ecoregion and Raleigh EUSE study watershed characteristics

33. Map summary of Piedmont Level III ecoregion watershed characteristics in the vicinity of Raleigh.

34. Graphs showing summary of Piedmont Level III ecoregion and Raleigh EUSE study watershed characteristics by percentage of urban development class.

35. Cumulative distribution plot of the percentage of urban development, forested, and agricultural land cover in the Piedmont Level III ecoregion watersheds, and the percentage of the same land-cover types in the Raleigh EUSE study watersheds ........76

36. Graphs showing summary of Northeastern Coastal Zone Level III ecoregion and Boston EUSE study watershed characteristics

37. Map summary of Northeastern Coastal Zone Level III ecoregion watershed characteristics

38. Graphs showing wummary of Northeastern Coastal Zone Level III ecoregion and Boston EUSE study watershed characteristics by percentage of urban development class

39. Cumulative distribution plot of the percentage of urban development, forested, and agricultural land cover in the Northeastern Coastal Zone Level III ecoregion watersheds, and the percentage of the same land-cover types in the Boston EUSE study watersheds

40. Maps showing climate zones within the range of precipitation and temperature values of the corresponding EUSE study watersheds 


\section{Tables}

1. Watershed characteristics used in the analysis of similarity .............................................

2. Summary of EUSE study area and Level III ecoregion watersheds................................. 4

3. Descriptive statistics for the EUSE and Level III ecoregion watersheds...........................

4. Distribution within percent development quintile class for the EUSE and Level III

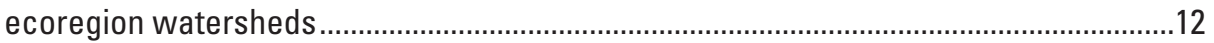

5. Kruskal-Wallis test for similarity between EUSE watersheds and Level III

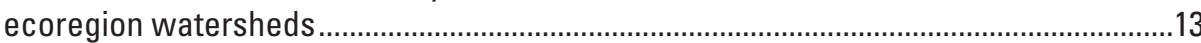

\section{Conversion Factors and Definitions}

\begin{tabular}{lcl}
\multicolumn{1}{c}{ SI to Inch/Pound } & \multicolumn{1}{c}{ Multiply } & To obtain \\
\hline & Length & \\
\hline centimeter (cm) & 0.3937 & inch (in.) \\
millimeter (mm) & 0.03937 & inch (in.) \\
meter (m) & 3.281 & foot (ft) \\
kilometer $(\mathrm{km})$ & 0.6214 & mile (mi) \\
meter $(\mathrm{m})$ & 1.094 & yard (yd) \\
\hline & Area & \\
\hline square kilometer $\left(\mathrm{km}^{2}\right)$ & 247.1 & acre \\
square kilometer $\left(\mathrm{km}^{2}\right)$ & 0.3861 & square mile $\left(\mathrm{mi}^{2}\right)$ \\
\hline
\end{tabular}

Temperature in degrees Celsius $\left({ }^{\circ} \mathrm{C}\right)$ may be converted to degrees Fahrenheit $\left({ }^{\circ} \mathrm{F}\right)$ as follows:

$$
{ }^{\circ} \mathrm{F}=\left(1.8 \times{ }^{\circ} \mathrm{C}\right)+32
$$

Vertical coordinate information is referenced to the North American Vertical Datum of 1988 (NAVD 88).

Horizontal coordinate information is referenced to North American Datum of 1983 (NAD 83).

Elevation, as used in this report, refers to distance above the vertical datum. 


\title{
Representation of Regional Urban Development Conditions Using a Watershed-Based Gradient Study Design
}

\author{
By Silvia Terziotti, Gerard McMahon, and Amanda H. Bell
}

\section{Abstract}

As part of the U.S. Geological Survey National WaterQuality Assessment Program, the effects of urbanization on stream ecosystems (EUSE) have been intensively investigated in nine metropolitan areas in the United States, including Boston, Massachusetts; Atlanta, Georgia; Birmingham, Alabama; Raleigh, North Carolina; Salt Lake City, Utah; Denver, Colorado; Dallas-Fort Worth, Texas; Portland, Oregon; and Milwaukee-Green Bay, Wisconsin. Each of the EUSE study area watersheds was associated with one ecological region of the United States. This report evaluates whether each metropolitan area can be generalized across the ecological regions (ecoregions) within which the EUSE study watersheds are located. Seven characteristics of the EUSE watersheds that affect stream ecosystems were examined to determine the similarities in the same seven characteristics of the watersheds in the entire ecoregion. Land cover (percentage developed, forest and shrubland, and herbaceous and cultivated classes), average annual temperature, average annual precipitation, average surface elevation, and average percentage slope were selected as human-influenced, climate, and topography characteristics. Three findings emerged from this comparison that have implications for the use of EUSE data in models used to predict stream ecosystem condition. One is that the predominant or "background" land-cover type (either forested or agricultural land) in each ecoregion also is the predominant land-cover type within the associated EUSE study watersheds. The second finding is that in all EUSE study areas, the watersheds account for the range of developed land conditions that exist in the corresponding ecoregion watersheds. However, six of the nine EUSE study area watersheds have significantly different distributions of developed land from the ecoregion watersheds. Finally, in seven of the nine EUSE/ecoregion comparisons, the distributions of the values of climate variables in the EUSE watersheds are different from the distributions for watersheds in the corresponding ecoregions.

\section{Introduction}

The U.S. Geological Survey's National Water-Quality Assessment (NAWQA) Program initiated a study in 1999 to investigate potential adverse effects of urban development on stream water quality. The effects of urbanization on stream ecosystems (EUSE) have been intensively investigated in nine metropolitan areas in the United States, including Boston, Massachusetts; Atlanta, Georgia; Birmingham, Alabama; Raleigh, North Carolina; Salt Lake City, Utah; Denver, Colorado; Dallas-Fort Worth, Texas; Portland, Oregon; and Milwaukee-Green Bay, Wisconsin (fig. 1; Brown and others, 2009). The primary objectives of the EUSE study were to examine the effects of urban development on physical, chemi$\mathrm{cal}$, and biological characteristics of streams and determine if the effects differ across the Nation.

A gradient design (Giddings and others, 2009) was used in the EUSE study in which approximately 30 watersheds were studied in each of the nine metropolitan areas. Together these watersheds represented a gradient of urbanization, ranging from low to high. To control for the effects on stream ecosystem condition of factors other than urban development (for example, climate and topography), EUSE watersheds in each metropolitan area were located within regions having relatively homogeneous environmental conditions, as defined by each U.S. Environmental Protection Agency (USEPA) Level III ecoregion (Omernik, 1995; fig. 1).

\section{Purpose and Scope}

The purpose of this report is to assess whether EUSE findings from each metropolitan area can be generalized across the Level III ecoregion within which the EUSE study watersheds are located. Seven characteristics of the EUSE watersheds that affect stream ecosystems were examined to determine the similarities in the same seven characteristics 


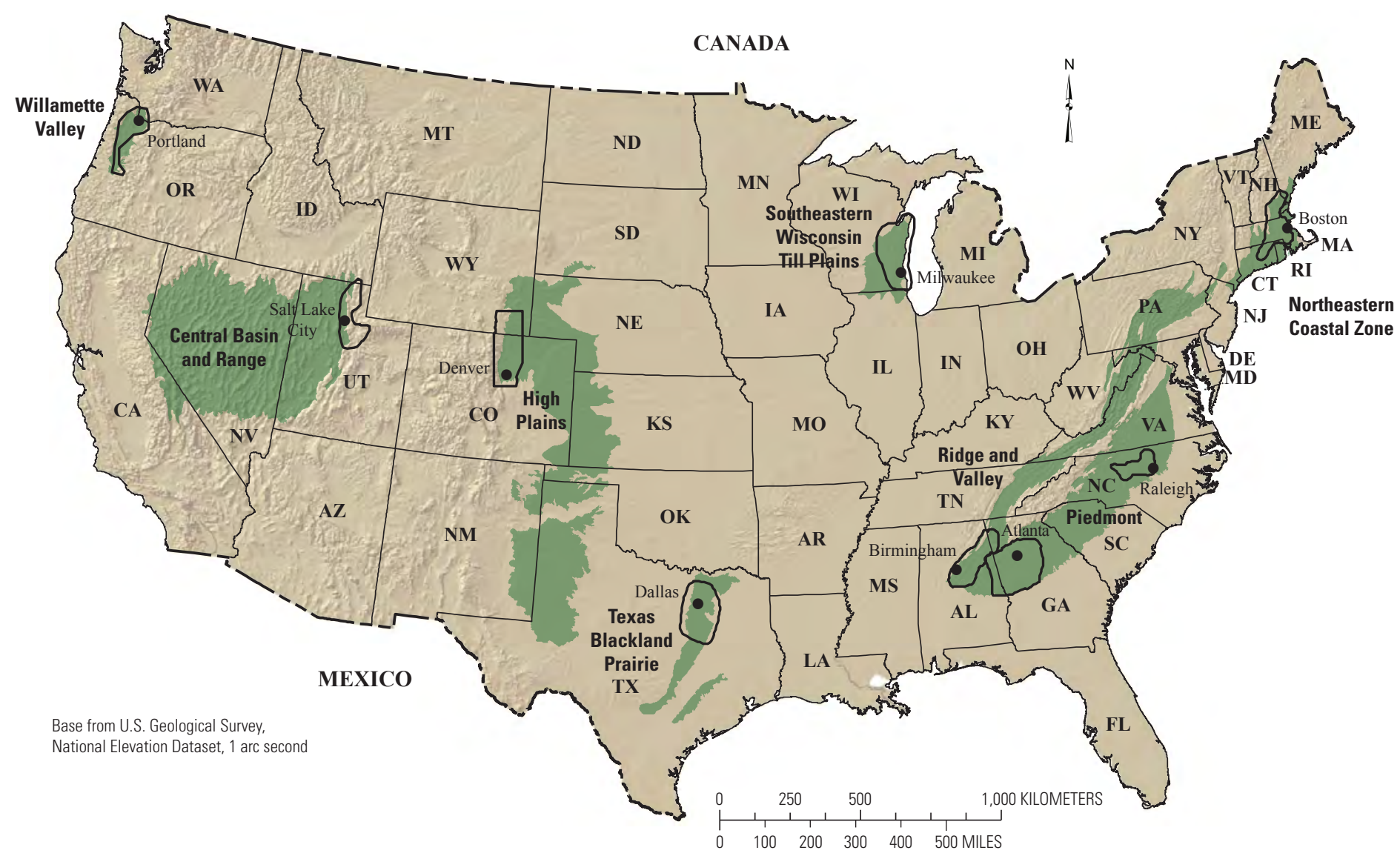

Figure 1. Effects of urbanization on stream ecosystems (EUSE) study areas and associated U.S. Environmental Protection Agency Level III ecoregions (from Falcone and others, 2007).

of the watersheds in the entire ecoregion-land cover (the percentage developed, forest and shrubland, and herbaceous and cultivated), average annual temperature, average annual precipitation, average elevation, and average percentage slope. If the EUSE study watershed characteristics have a similar distribution and range of values when compared to the same characteristics of watersheds in the corresponding ecoregion, the EUSE watersheds can be considered representative of other similarly sized watersheds across the ecoregion, thereby indicating each EUSE study can be generalized to other locations within an ecoregion.

The nine metropolitan areas in the EUSE study (Boston, Massachusetts; Atlanta, Georgia; Birmingham, Alabama; Raleigh, North Carolina; Salt Lake City, Utah; Denver, Colorado; Dallas-Fort Worth, Texas; Portland, Oregon; and Milwaukee-Green Bay, Wisconsin) were compared to the eight Level III ecoregions where they are located.

\section{Methods}

To minimize natural variations that may affect stream ecosystems, the majority of EUSE study watersheds for each metropolitan area were selected from within one Level III ecoregion, which have been delineated on the basis of relatively homogeneous environmental characteristics. For each of the nine metropolitan areas, a group of similarly sized watersheds was identified from within the associated ecoregion, and the following watershed characteristics were calculated using geographic information system (GIS) processes:

1. Percentage of developed land

2. Percentage of forest and scrub/shrubland

3. Percentage of agriculture and grassland/herbaceous land

4. Average annual precipitation

5. Average annual temperature

6. Average elevation

7. Average percentage slope 
The variables were selected because they capture a variety of anthropogenic, climatic, and surface topographic characteristics, which are important in stream ecosystem health. For each of these variables, characteristics of the EUSE study watersheds are compared to the same characteristics of similarly sized watersheds in the corresponding Level III ecoregion. This comparison is the basis for assessing the degree to which EUSE study watersheds are representative of the range and distribution of these characteristics across the entire ecoregion. Table 1 lists the source and variables used to characterize the ecoregion watersheds and the EUSE study watersheds.

Table 1. Watershed characteristics used in the analysis of similarity.

\begin{tabular}{|c|c|c|}
\hline Variable & Source & Dataset used \\
\hline \multicolumn{3}{|c|}{ Climate variables } \\
\hline $\begin{array}{l}\text { Average annual air temperature } \\
\text { (TEMP) }\end{array}$ & $\begin{array}{l}\text { University of Montana, Numerical Terradynamic } \\
\text { Simulation Group, http://www.daymet.org } \\
\text { (Daymet, 2005) }\end{array}$ & $\begin{array}{l}\text { Daymet, 18-year mean of daily average air } \\
\text { temperature, in degrees Celsius, 1980-1997 }\end{array}$ \\
\hline $\begin{array}{l}\text { Average annual precipitation } \\
\text { (PRECIP) }\end{array}$ & $\begin{array}{l}\text { University of Montana, Numerical Terradynamic } \\
\text { Simulation Group, http://www.daymet.org } \\
\text { (Daymet, 2005) }\end{array}$ & $\begin{array}{l}\text { Daymet, 18-year mean of total precipitation, } \\
\text { in centimeters, } 1980-1997\end{array}$ \\
\hline \multicolumn{3}{|c|}{ Topographic variables } \\
\hline Average elevation (ELEV) & $\begin{array}{l}\text { U.S. Geological Survey, http://ned.usgs.gov } \\
\text { (U.S. Geological Survey, 2005) }\end{array}$ & $\begin{array}{l}\text { National Elevation Dataset (NED), } 1 \text { arc-second } \\
\quad \text { data (projected to } 30 \text { meter) }\end{array}$ \\
\hline Average percent slope (SLOPE) & $\begin{array}{l}\text { U.S. Geological Survey, http://ned.usgs.gov } \\
\text { (U.S. Geological Survey, 2005) }\end{array}$ & $\begin{array}{l}\text { National Elevation Dataset (NED), } 1 \text { arc-second } \\
\text { data (projected to } 30 \text { meter), calculated to } \\
\text { percent slope }\end{array}$ \\
\hline \multicolumn{3}{|c|}{ Land-cover variables } \\
\hline $\begin{array}{l}\text { Percent forest, scrub/shrubland } \\
\text { (FOR) }\end{array}$ & $\begin{array}{l}\text { Multi-Resolution Land Characteristics (MRLC) } \\
\text { Consortium, http://www.mrlc.gov } \\
\text { (Homer and others, 2004) }\end{array}$ & $\begin{array}{l}\text { National Land Cover Database, 2001, land cover } \\
\text { class } 41,42,43,52\end{array}$ \\
\hline $\begin{array}{l}\text { Percent agricultural, and } \\
\text { grassland/herbaceous (AG) }\end{array}$ & $\begin{array}{l}\text { Multi-Resolution Land Characteristics (MRLC) } \\
\text { Consortium, http://www.mrlc.gov } \\
\text { (Homer and others, 2004) }\end{array}$ & $\begin{array}{l}\text { National Land Cover Database, 2001, land cover } \\
\text { class } 71,81,82\end{array}$ \\
\hline
\end{tabular}




\section{Ecoregion Watershed Delineation}

The minimum and maximum drainage areas for the EUSE study watersheds were used as the criteria to select the watersheds within each Level III ecoregion. In order to identify similarly sized watersheds within a Level III ecoregion, the National Hydrography Dataset Plus (NHDPlus) application was used. NHDPlus is an integrated suite of application-ready geospatial data products that can be used to calculate watershed characteristics linked to a hydrologic flow network for simulating watershed and stream-network processes (National Hydrography Dataset Plus, 2009). NHDPlus includes a stream network (currently based on the 1:100,000-scale NHD) and "value-added attribute" (VAA) tables. The stream networks and VAAs include greatly enhanced capabilities for upstream and downstream navigation, analysis, and modeling. The NHDPlus also includes a catchment layer, the drainage area associated with each stream segment, as well as stream segment, cumulative upstream segment, and watershed characteristics.
Catchment areas within the boundary of each ecoregion were selected from the NHDPlus datasets. These catchments were joined with the VAAs that define the cumulative drainage area. The minimum and maximum drainage area values of EUSE watersheds were used as the threshold values for the selection of catchments from the NHDPlus dataset. Because the catchments are defined at confluences of streams, a smaller catchment may be "nested" within a catchment that is above the minimum threshold and below the maximum threshold area (fig. 2). To reduce the number of nested watersheds used for comparison, the nested watersheds within the minimum and maximum values were aggregated, therefore weighting the selection toward the larger watershed size. To capture watersheds that may have topographic or land-cover characteristics specific to small watershed size, the minimum drainage area value was used to select a second set of catchments that was combined with the larger watersheds (fig. 3). The combination of these two sets of catchments, herein referred to as "ecoregion watersheds," composed the watersheds that were used in the comparison with the corresponding EUSE study watersheds. Because of the wide range of sizes in ecoregions, the number of selected watersheds ranged from 297 to more than 11,000 (table 2).

Table 2. Summary of EUSE study area and Level III ecoregion watersheds.

[EUSE, effects of urbanization on stream ecosystems; $\mathrm{km}^{2}$, square kilometer]

\begin{tabular}{|c|c|c|c|c|c|c|}
\hline $\begin{array}{l}\text { EUSE study } \\
\text { metropolitan } \\
\text { area }\end{array}$ & Level III ecoregion & $\begin{array}{c}\text { Number of } \\
\text { watersheds } \\
\text { in EUSE } \\
\text { study }\end{array}$ & $\begin{array}{c}\text { Range of } \\
\text { watershed size } \\
\text { in EUSE study } \\
\left(\mathbf{k m}^{2}\right)\end{array}$ & $\begin{array}{c}\text { Number of } \\
\text { watersheds in } \\
\text { ecoregion with } \\
\text { comparable } \\
\text { watershed area }\end{array}$ & $\begin{array}{c}\text { Range of } \\
\text { watershed size } \\
\text { in ecoregion } \\
\left(\mathbf{k m}^{2}\right)\end{array}$ & $\begin{array}{c}\text { Ecoregion } \\
\text { area } \\
\left(\mathbf{k m}^{2}\right)\end{array}$ \\
\hline Portland & Willamette Valley & 28 & $12.6-103.8$ & 297 & $12.6-102.8$ & $14,884.66$ \\
\hline Salt Lake City & Central Basin and Range & 30 & $0.1-28.9$ & 11,081 & $0.1-28.9$ & $309,971.94$ \\
\hline Dallas & Texas Blackland Prairie & 29 & $26.8-291.4$ & 435 & $26.8-289.5$ & $43,381.95$ \\
\hline Milwaukee & $\begin{array}{l}\text { Southeastern Wisconsin } \\
\text { Till Plains }\end{array}$ & 30 & $11.2-118.8$ & 616 & $11.2-117.9$ & $31,350.28$ \\
\hline Birmingham & Ridge and Valley & 30 & $4.7-54.4$ & 4,543 & $4.7-54.3$ & $116,715.91$ \\
\hline Atlanta & Piedmont & 30 & $43.2-146.3$ & 1,431 & $43.2-146.3$ & $166,117.40$ \\
\hline
\end{tabular}




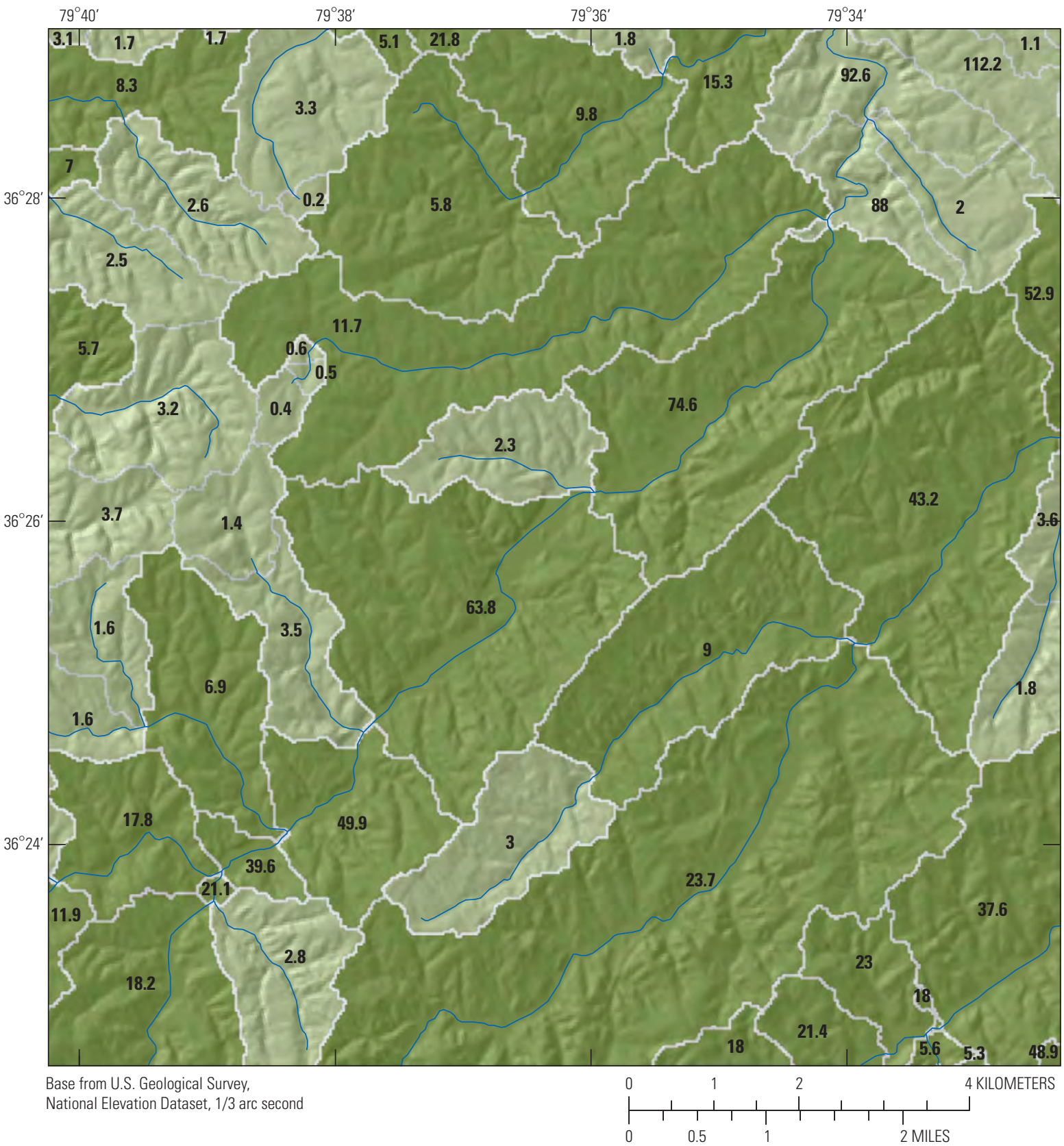

\section{EXPLANATION}

Raleigh metropolitan area, Piedmont Level III ecoregion Upstream catchment areas (drainage area smaller than 4.9 square kilometers)

Cumulative drainage area values between 4.9 and 82.5 square kilometers

Figure 2. National Hydrography Dataset Plus (NHDPlus) nested catchment areas, Raleigh, North Carolina, metropolitan area. 

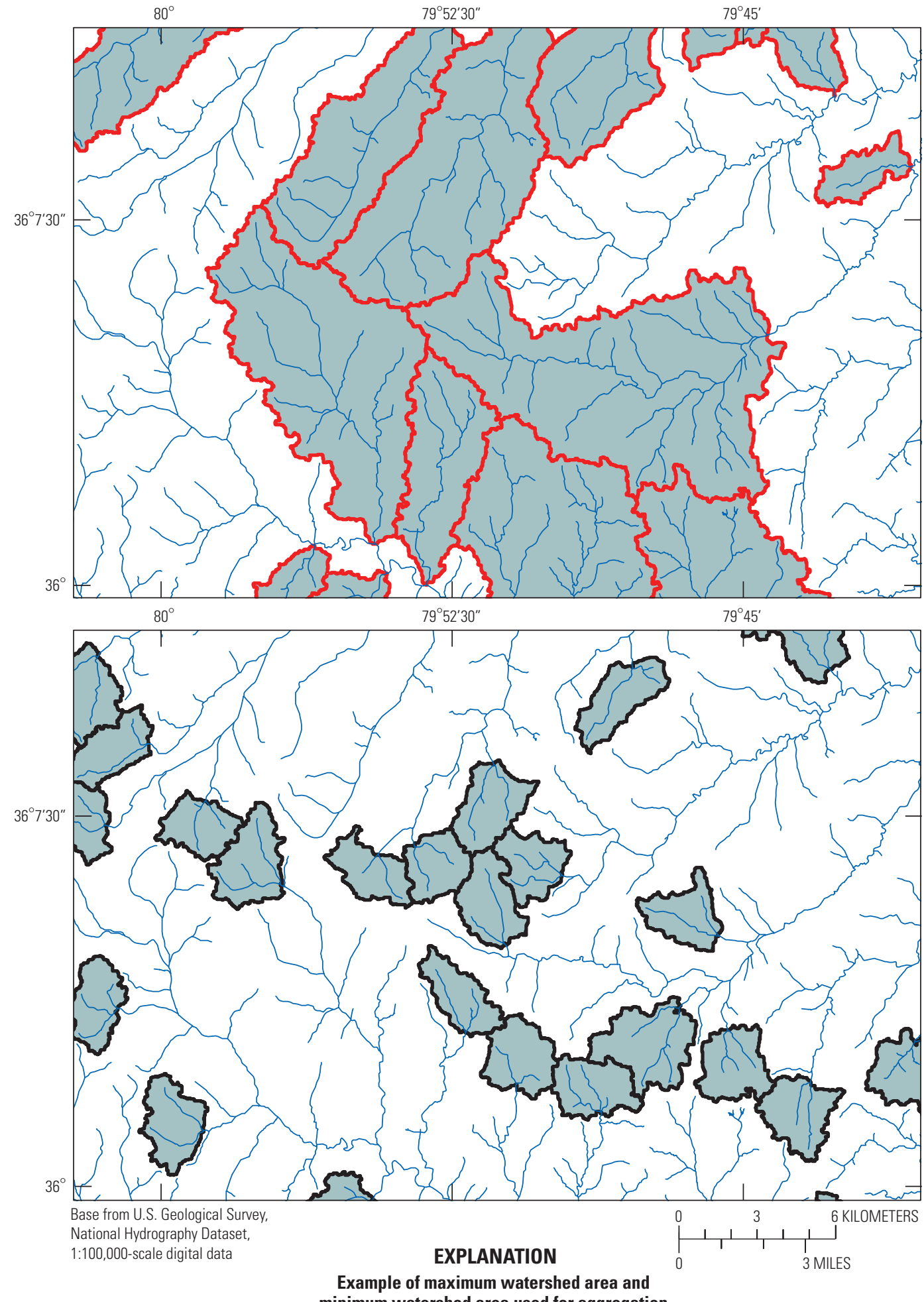
minimum watershed area used for aggregation

Watersheds aggregated on the basis of maximum drainage area

Watersheds aggregated on the basis of minimum drainage area

Figure 3. Examples of aggregated National Hydrography Dataset Plus (NHDPlus) watersheds used for analysis of basin characteristics. 


\section{Representing Variations in Urban Gradients Among Study Units}

The amount and spatial distribution of land that is classified as "urban" varies across the Level III ecoregions where the EUSE study areas are located (Omernik, 1995). When examining watersheds of a given size, some ecoregions, such as the Central Basin and Range ecoregion (Salt Lake City EUSE study area), have a relatively small proportion of watersheds with a medium to high percentage of developed land; other ecoregions, such as the Northeastern Coastal Zone (Boston study), have a larger proportion of watersheds with a medium to high percentage of developed land.

Cumulative distribution function (CDF) graphs can help visualize the skew within a population toward a characteristic. The blue line in the figure represents the cumulative percentage of ecoregion watersheds, sorted and ranked by the percentage of developed land cover. Any location along the blue line is interpreted in terms of the corresponding locations along the $\mathrm{X}$ - and $\mathrm{Y}$-axes. A straight line would indicate a uniform distribution, from 0 to 100 percent developed with an equal number of watersheds representing each percentage of development. In reality, most regions are more heavily weighted toward areas with little development and a few areas of high development. For example, more than 95 percent of the watersheds in the Central Basin and Range ecoregion (Salt Lake City) have less than 20 percent developed land (20 percent developed land on the $X$-axis intersects the blue line at a cumulative percentage on the $\mathrm{Y}$-axis at slightly greater than 95 percent). In the Northeastern Coastal Zone ecoregion (Boston), the blue line has a more gradual shape than in the other ecoregions; more than 60 percent of the watersheds in this ecoregion have at least 20 percent developed land cover.

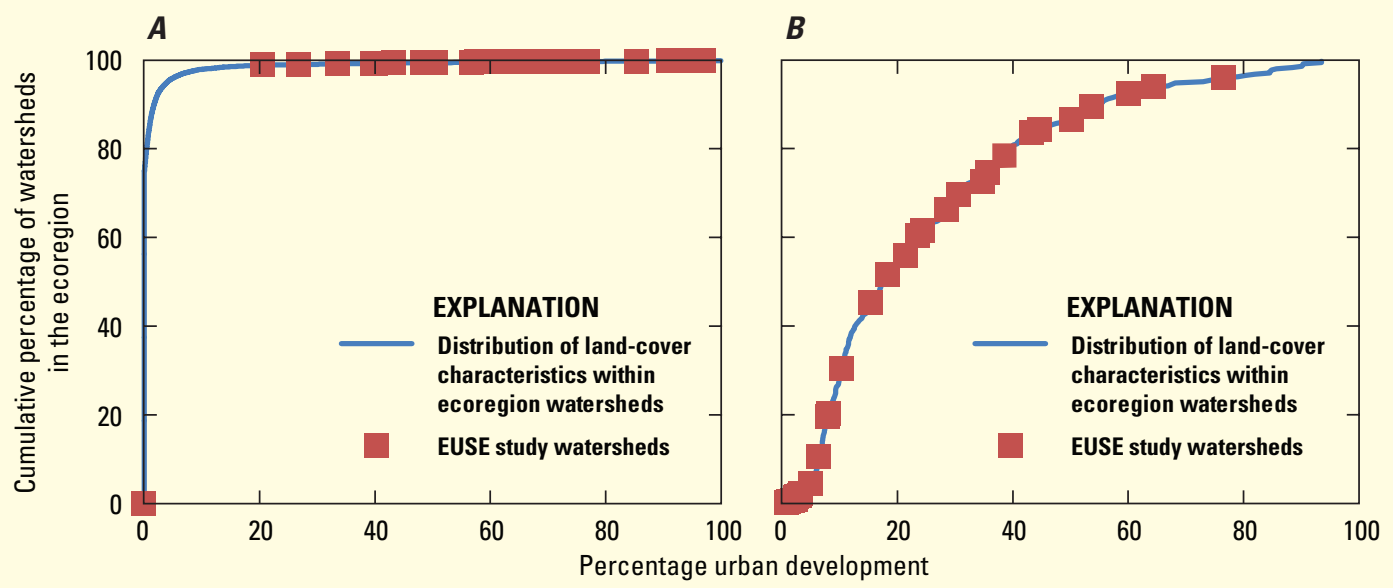

Percentage of urban land cover cumulative distribution function (CDF) for (A) Salt Lake City, Utah, and $(B)$ Boston, Massachusetts. Red squares indicate the actual amount of developed land in the approximately 30 EUSE study watersheds in a single ecoregion. The extent to which the EUSE study watersheds represents the urban gradient in an ecoregion can be seen in the CDF plots by how evenly the EUSE study watersheds (red squares) are spaced relative to the percentage developed land (X-axis), irrespective of the shape of the blue line. 


\section{Methods of Comparison}

Descriptive statistics were used to compare the similarities between the quantitative characteristics of ecoregion watersheds and the EUSE watersheds. The ranges of values for each of the watershed characteristics and the minimum, first quartile, median, third quartile, maximum, and mean values are presented in tabular form for all watersheds (table 3). Boxplots are used to visualize the distribution of watershed characteristics for the ecoregion watersheds and the EUSE study watersheds. A cumulative distribution function (CDF; Helsel and Hirsch, 2002) was compiled for the developed, forested, and agricultural land-cover percentages in the ecoregion watersheds; the respective land-cover percentages for the EUSE watersheds in each ecoregion are overplotted on the CDF to indicate which portions of the cumulative distribution are represented by the EUSE watersheds (sidebar, p. 7). A series of analytic maps are also presented to aid in visually evaluating the similarity between variable values of the EUSE study areas and different areas of the associated ecoregion. The Kruskal-Wallis (K-W) test, a nonparametric measure of similarity of medians between two populations, is used to test whether each of the basin characteristics have statistically similar distributions between the EUSE and ecoregion watersheds (Helsel and Hirsch, 2002). A secondary analysis was performed using boxplots to compare the EUSE and ecoregion watersheds that are within similar ranges of urban development. The ecoregion watersheds were subdivided into five development classes or quintiles: 0-20 percent, $20-40$ percent, $40-60$ percent, $60-80$ percent, and 80-100 percent developed (table 4). The number of watersheds within each of these classes was compared to the number of corresponding EUSE watersheds within the development class. Analysis by development class relied primarily on comparisons displayed on the boxplots. Limited statistical analysis could be done because of the scarcity of EUSE sites within some of the development classes.

\section{Results}

The nine EUSE study areas are located in eight different Level III ecoregions (table 2). The similarly sized watersheds in each ecoregion are one to three orders of magnitude greater than the number of watersheds actually assessed in each EUSE study area. 
Table 3. Descriptive statistics for the EUSE and Level III ecoregion watersheds.

[EUSE, effects of urbanization on stream ecosystems]

\begin{tabular}{|c|c|c|c|c|c|c|c|c|c|}
\hline Study area & & & $\begin{array}{c}\text { Average } \\
\text { annual } \\
\text { temperature, } \\
\text { degrees } \\
\text { Celsius }\end{array}$ & $\begin{array}{c}\text { Average } \\
\text { annual } \\
\text { precipitation, } \\
\text { centimeters }\end{array}$ & $\begin{array}{l}\text { Average } \\
\text { elevation, } \\
\text { meters }\end{array}$ & $\begin{array}{c}\text { Average } \\
\text { watershed } \\
\text { percent slope }\end{array}$ & $\begin{array}{c}\text { Percent } \\
\text { developed }\end{array}$ & $\begin{array}{c}\text { Percent } \\
\text { forest }\end{array}$ & $\begin{array}{c}\text { Percent } \\
\text { agriculture }\end{array}$ \\
\hline \multirow{7}{*}{$\begin{array}{l}\text { Willamette } \\
\text { Valley }\end{array}$} & \multirow{7}{*}{$\begin{array}{l}\text { Ecoregion } \\
\text { watersheds } \\
\text { (count=297) }\end{array}$} & minimum & 9.6 & 110.7 & 3.5 & 0.2 & 0.0 & 0.0 & 0.3 \\
\hline & & 1st quartile & 10.9 & 127.4 & 88.4 & 4.1 & 4.8 & 6.3 & 24.6 \\
\hline & & median & 11.3 & 138.7 & 142.3 & 9.7 & 7.7 & 26.9 & 44.2 \\
\hline & & 3rd quartile & 11.5 & 157.0 & 214.2 & 15.5 & 13.6 & 58.9 & 72.5 \\
\hline & & maximum & 11.9 & 199.0 & 455.4 & 32.0 & 92.0 & 93.8 & 94.4 \\
\hline & & mean & 11.2 & 142.9 & 160.1 & 10.4 & 14.7 & 33.8 & 47.6 \\
\hline & & range & 2.4 & 88.3 & 451.9 & 31.8 & 92.0 & 93.8 & 94.0 \\
\hline \multirow[t]{7}{*}{ Portland } & \multirow{7}{*}{$\begin{array}{l}\text { EUSE } \\
\text { watersheds } \\
(\text { count=28) }\end{array}$} & minimum & 8.9 & 116.3 & 52.7 & 1.0 & 0.2 & 0.1 & 1.9 \\
\hline & & 1st quartile & 10.2 & 126.8 & 114.5 & 8.3 & 3.4 & 17.7 & 7.6 \\
\hline & & median & 11.1 & 141.4 & 183.7 & 11.8 & 20.5 & 34.3 & 16.5 \\
\hline & & 3rd quartile & 11.4 & 173.1 & 282.7 & 16.6 & 60.1 & 72.4 & 33.7 \\
\hline & & maximum & 11.8 & 204.7 & 621.3 & 32.9 & 97.8 & 94.6 & 58.5 \\
\hline & & mean & 10.8 & 147.5 & 220.2 & 13.4 & 31.8 & 44.1 & 21.6 \\
\hline & & range & 2.9 & 88.3 & 568.6 & 31.9 & 97.7 & 94.5 & 56.6 \\
\hline \multirow{7}{*}{$\begin{array}{l}\text { Central Basin } \\
\text { and Range }\end{array}$} & \multirow{7}{*}{$\begin{array}{l}\text { Ecoregion } \\
\text { watersheds } \\
(\text { count }=11,081)\end{array}$} & minimum & -1.4 & 10.5 & 896.0 & 0.0 & 0.0 & 0.0 & 0.0 \\
\hline & & 1st quartile & 7.6 & 23.2 & $1,558.8$ & 6.3 & 0.0 & 90.7 & 0.0 \\
\hline & & median & 8.7 & 30.5 & $1,752.2$ & 12.9 & 0.0 & 98.4 & 0.5 \\
\hline & & 3rd quartile & 10.0 & 38.0 & $1,960.1$ & 21.1 & 0.0 & 99.9 & 5.3 \\
\hline & & maximum & 16.3 & 89.7 & $3,507.3$ & 77.5 & 100.0 & 100.0 & 100.0 \\
\hline & & mean & 8.8 & 31.5 & $1,777.2$ & 14.7 & 0.9 & 89.2 & 7.2 \\
\hline & & range & 17.7 & 79.3 & $2,611.2$ & 77.5 & 100.0 & 100.0 & 100.0 \\
\hline \multirow[t]{7}{*}{ Salt Lake City } & \multirow{7}{*}{$\begin{array}{l}\text { EUSE } \\
\text { watersheds } \\
(\text { count=30) }\end{array}$} & minimum & 4.1 & 51.9 & $1,369.6$ & 4.2 & 0.0 & 0.9 & 0.0 \\
\hline & & 1st quartile & 9.6 & 63.4 & $1,409.1$ & 9.3 & 44.5 & 7.1 & 0.7 \\
\hline & & median & 10.1 & 66.0 & $1,466.7$ & 12.3 & 65.3 & 17.0 & 5.3 \\
\hline & & 3rd quartile & 10.4 & 68.8 & $1,496.9$ & 22.7 & 73.8 & 35.0 & 9.5 \\
\hline & & maximum & 11.1 & 115.2 & $2,353.1$ & 57.8 & 96.9 & 99.8 & 32.7 \\
\hline & & mean & 9.7 & 68.0 & $1,486.8$ & 17.8 & 59.5 & 25.2 & 7.4 \\
\hline & & range & 7.0 & 63.3 & 983.5 & 53.7 & 96.9 & 99.0 & 32.7 \\
\hline \multirow[t]{7}{*}{ High Plains } & \multirow{7}{*}{$\begin{array}{l}\text { Ecoregion } \\
\text { watersheds } \\
(\text { count=2,881) }\end{array}$} & minimum & 6.5 & 31.4 & 712.8 & 0.2 & 0.0 & 0.0 & 0.0 \\
\hline & & 1st quartile & 8.9 & 42.5 & 989.8 & 1.5 & 1.2 & 0.0 & 88.3 \\
\hline & & median & 10.5 & 46.3 & $1,130.5$ & 2.9 & 2.5 & 0.3 & 95.4 \\
\hline & & 3rd quartile & 12.5 & 50.9 & $1,380.9$ & 5.3 & 3.7 & 4.9 & 97.3 \\
\hline & & maximum & 17.9 & 65.5 & $2,097.0$ & 22.5 & 100.0 & 99.9 & 100.0 \\
\hline & & mean & 10.8 & 46.7 & $1,191.2$ & 4.1 & 3.7 & 7.0 & 88.1 \\
\hline & & range & 11.5 & 34.0 & $1,384.1$ & 22.3 & 100.0 & 99.9 & 100.0 \\
\hline \multirow[t]{7}{*}{ Denver } & \multirow{7}{*}{$\begin{array}{l}\text { EUSE } \\
\text { watersheds } \\
(\text { count=28) }\end{array}$} & minimum & 6.5 & 38.1 & $1,535.4$ & 1.7 & 1.5 & 0.4 & 2.4 \\
\hline & & 1st quartile & 9.1 & 40.5 & $1,615.7$ & 4.1 & 15.1 & 1.8 & 28.0 \\
\hline & & median & 9.4 & 43.2 & $1,720.0$ & 5.8 & 35.6 & 2.5 & 57.7 \\
\hline & & 3rd quartile & 9.6 & 45.4 & $1,772.9$ & 8.3 & 64.8 & 4.1 & 79.8 \\
\hline & & maximum & 9.9 & 46.8 & $2,023.6$ & 12.4 & 90.4 & 15.7 & 95.0 \\
\hline & & mean & 9.2 & 43.0 & $1,704.3$ & 6.2 & 41.0 & 3.5 & 52.5 \\
\hline & & range & 3.4 & 8.6 & 488.2 & 10.8 & 89.0 & 15.3 & 92.6 \\
\hline
\end{tabular}


Table 3. Descriptive statistics for the EUSE and Level III ecoregion watersheds.-Continued

[EUSE, effects of urbanization on stream ecosystems]

\begin{tabular}{|c|c|c|c|c|c|c|c|c|c|}
\hline Study area & & & $\begin{array}{c}\text { Average } \\
\text { annual } \\
\text { temperature, } \\
\text { degrees } \\
\text { Celsius }\end{array}$ & $\begin{array}{c}\text { Average } \\
\text { annual } \\
\text { precipitation, } \\
\text { centimeters }\end{array}$ & $\begin{array}{c}\text { Average } \\
\text { elevation, } \\
\text { meters }\end{array}$ & $\begin{array}{c}\text { Average } \\
\text { watershed } \\
\text { percent slope }\end{array}$ & $\begin{array}{c}\text { Percent } \\
\text { developed }\end{array}$ & $\begin{array}{c}\text { Percent } \\
\text { forest }\end{array}$ & $\begin{array}{c}\text { Percent } \\
\text { agriculture }\end{array}$ \\
\hline Texas & Ecoregion & minimum & 17.1 & 71.0 & 60.2 & 0.8 & 0.4 & 0.0 & 0.1 \\
\hline Blackland & watersheds & 1st quartile & 18.1 & 91.8 & 132.6 & 1.8 & 4.7 & 7.0 & 55.1 \\
\hline \multirow[t]{5}{*}{ Prairie } & $($ count $=435)$ & median & 18.8 & 101.2 & 160.5 & 2.3 & 6.1 & 12.6 & 74.1 \\
\hline & & 3rd quartile & 20.0 & 109.4 & 184.7 & 2.9 & 9.6 & 20.8 & 82.6 \\
\hline & & maximum & 21.0 & 126.5 & 295.4 & 5.0 & 98.7 & 72.7 & 97.4 \\
\hline & & mean & 18.9 & 101.0 & 161.6 & 2.4 & 14.6 & 16.3 & 65.6 \\
\hline & & range & 3.9 & 55.5 & 235.2 & 4.2 & 98.2 & 72.7 & 97.3 \\
\hline \multirow[t]{7}{*}{ Dallas } & EUSE & minimum & 17.6 & 96.3 & 121.4 & 1.3 & 1.6 & 5.7 & 3.5 \\
\hline & watersheds & 1st quartile & 18.2 & 101.4 & 140.4 & 1.8 & 3.1 & 11.1 & 42.7 \\
\hline & $($ count $=29)$ & median & 18.4 & 104.4 & 168.9 & 2.1 & 6.9 & 15.1 & 70.3 \\
\hline & & 3rd quartile & 18.5 & 105.8 & 196.3 & 2.8 & 21.3 & 25.0 & 76.9 \\
\hline & & maximum & 18.7 & 111.3 & 220.3 & 3.7 & 88.8 & 34.4 & 85.7 \\
\hline & & mean & 18.3 & 104.3 & 170.3 & 2.3 & 24.1 & 17.4 & 57.1 \\
\hline & & range & 1.1 & 14.9 & 98.9 & 2.4 & 87.2 & 28.7 & 82.2 \\
\hline \multirow{7}{*}{$\begin{array}{l}\text { Southeastern } \\
\text { Wisconsin } \\
\text { Till Plains }\end{array}$} & Ecoregion & minimum & 6.7 & 76.9 & 191.4 & 0.1 & 1.2 & 0.0 & 0.0 \\
\hline & watersheds & 1st quartile & 7.4 & 85.3 & 246.4 & 1.9 & 4.6 & 5.0 & 56.1 \\
\hline & $($ count $=616)$ & median & 7.7 & 89.0 & 264.8 & 2.6 & 6.1 & 8.4 & 71.9 \\
\hline & & 3rd quartile & 8.1 & 91.2 & 282.5 & 3.6 & 11.3 & 14.1 & 81.3 \\
\hline & & maximum & 9.0 & 96.8 & 341.4 & 8.6 & 100.0 & 55.0 & 96.7 \\
\hline & & mean & 7.7 & 88.3 & 264.4 & 2.8 & 12.7 & 10.5 & 66.3 \\
\hline & & range & 2.3 & 19.9 & 150.0 & 8.5 & 98.9 & 55.0 & 96.7 \\
\hline \multirow[t]{7}{*}{ Milwaukee } & EUSE & minimum & 6.8 & 78.6 & 201.8 & 1.0 & 3.2 & 0.7 & 0.0 \\
\hline & watersheds & 1st quartile & 7.0 & 83.2 & 222.0 & 1.6 & 5.4 & 4.8 & 28.0 \\
\hline & $($ count $=30)$ & median & 7.4 & 85.2 & 234.2 & 2.1 & 16.9 & 5.9 & 66.0 \\
\hline & & 3rd quartile & 8.3 & 88.6 & 247.6 & 2.7 & 61.9 & 10.9 & 78.4 \\
\hline & & maximum & 8.7 & 90.6 & 272.9 & 3.3 & 99.1 & 23.0 & 88.0 \\
\hline & & mean & 7.6 & 85.5 & 236.1 & 2.2 & 33.5 & 8.3 & 53.3 \\
\hline & & range & 1.9 & 12.0 & 71.1 & 2.3 & 95.8 & 22.3 & 88.0 \\
\hline \multirow{7}{*}{$\begin{array}{l}\text { Ridge and } \\
\text { Valley }\end{array}$} & Ecoregion & minimum & 6.4 & 89.7 & 87.5 & 1.2 & 0.0 & 0.2 & 0.0 \\
\hline & watersheds & 1st quartile & 10.0 & 109.0 & 238.2 & 9.6 & 3.7 & 41.0 & 8.7 \\
\hline & $(\operatorname{coun}=4,543)$ & median & 11.5 & 119.4 & 332.4 & 16.0 & 6.1 & 63.2 & 23.4 \\
\hline & & 3rd quartile & 14.2 & 137.7 & 497.0 & 21.3 & 10.5 & 82.7 & 42.3 \\
\hline & & maximum & 17.2 & 160.0 & $1,199.5$ & 44.4 & 96.4 & 100.0 & 93.7 \\
\hline & & mean & 12.0 & 122.3 & 393.8 & 14.4 & 10.1 & 60.7 & 27.6 \\
\hline & & range & 10.8 & 70.3 & $1,112.1$ & 43.2 & 96.4 & 99.9 & 93.7 \\
\hline
\end{tabular}


Table 3. Descriptive statistics for the EUSE and Level III ecoregion watersheds.-Continued

[EUSE, effects of urbanization on stream ecosystems]

\begin{tabular}{|c|c|c|c|c|c|c|c|c|c|}
\hline Study area & & & $\begin{array}{c}\text { Average } \\
\text { annual } \\
\text { temperature, } \\
\text { degrees } \\
\text { Celsius }\end{array}$ & $\begin{array}{c}\text { Average } \\
\text { annual } \\
\text { precipitation, } \\
\text { centimeters }\end{array}$ & $\begin{array}{l}\text { Average } \\
\text { elevation, } \\
\text { meters }\end{array}$ & $\begin{array}{c}\text { Average } \\
\text { watershed } \\
\text { percent slope }\end{array}$ & $\begin{array}{c}\text { Percent } \\
\text { developed }\end{array}$ & $\begin{array}{l}\text { Percent } \\
\text { forest }\end{array}$ & $\begin{array}{c}\text { Percent } \\
\text { agriculture }\end{array}$ \\
\hline \multirow[t]{7}{*}{ Birmingham } & \multirow{7}{*}{$\begin{array}{l}\text { EUSE } \\
\text { watersheds } \\
(\text { count }=30)\end{array}$} & minimum & 14.7 & 141.2 & 161.5 & 2.9 & 2.8 & 3.7 & 0.6 \\
\hline & & 1st quartile & 15.7 & 145.6 & 193.4 & 8.6 & 13.5 & 36.4 & 3.3 \\
\hline & & median & 16.1 & 147.0 & 231.4 & 11.0 & 36.4 & 44.8 & 9.8 \\
\hline & & 3rd quartile & 16.5 & 148.1 & 273.7 & 12.8 & 57.2 & 64.1 & 19.0 \\
\hline & & maximum & 16.8 & 151.5 & 324.4 & 16.2 & 95.7 & 76.7 & 37.7 \\
\hline & & mean & 16.0 & 146.7 & 234.9 & 10.5 & 40.1 & 46.0 & 11.7 \\
\hline & & range & 2.1 & 10.3 & 162.9 & 13.2 & 92.9 & 73.0 & 37.1 \\
\hline \multirow[t]{7}{*}{ Piedmont } & \multirow{7}{*}{$\begin{array}{l}\text { Ecoregion } \\
\text { watersheds } \\
(\text { count=1,431) }\end{array}$} & minimum & 12.8 & 108.1 & 73.2 & 2.3 & 0.3 & 2.7 & 0.3 \\
\hline & & 1st quartile & 14.3 & 117.1 & 151.6 & 5.1 & 4.2 & 47.9 & 18.1 \\
\hline & & median & 15.5 & 121.4 & 202.7 & 6.2 & 6.3 & 60.3 & 25.8 \\
\hline & & 3rd quartile & 16.4 & 130.4 & 263.6 & 7.7 & 10.9 & 69.4 & 34.3 \\
\hline & & maximum & 17.7 & 168.6 & 504.6 & 20.4 & 96.4 & 97.6 & 62.0 \\
\hline & & mean & 15.4 & 124.5 & 213.1 & 6.8 & 11.6 & 58.2 & 26.5 \\
\hline & & range & 4.9 & 60.5 & 431.4 & 18.1 & 96.2 & 94.9 & 61.7 \\
\hline \multirow[t]{7}{*}{ Atlanta } & \multirow{7}{*}{$\begin{array}{l}\text { EUSE } \\
\text { watersheds } \\
(\text { count=30) }\end{array}$} & minimum & 15.6 & 122.0 & 178.3 & 4.2 & 2.3 & 11.5 & 2.1 \\
\hline & & 1st quartile & 15.9 & 128.9 & 255.2 & 5.3 & 6.3 & 39.6 & 12.4 \\
\hline & & median & 16.1 & 133.6 & 283.2 & 5.9 & 22.5 & 45.5 & 19.3 \\
\hline & & 3rd quartile & 16.6 & 138.3 & 309.1 & 6.6 & 41.8 & 62.1 & 25.9 \\
\hline & & maximum & 17.5 & 140.8 & 350.0 & 11.0 & 85.4 & 74.8 & 39.7 \\
\hline & & mean & 16.3 & 133.5 & 278.3 & 6.1 & 27.8 & 48.0 & 19.2 \\
\hline & & range & 2.0 & 18.8 & 171.6 & 6.8 & 83.1 & 63.2 & 37.7 \\
\hline \multirow[t]{7}{*}{ Piedmont } & \multirow{7}{*}{$\begin{array}{l}\text { Ecoregion } \\
\text { watersheds } \\
(\text { count }=6,512)\end{array}$} & minimum & 12.4 & 107.0 & 52.3 & 1.4 & 0.0 & 0.1 & 0.0 \\
\hline & & 1st quartile & 14.2 & 116.3 & 142.5 & 5.1 & 3.7 & 47.8 & 15.1 \\
\hline & & median & 15.4 & 120.7 & 200.7 & 6.3 & 5.7 & 61.5 & 24.8 \\
\hline & & 3rd quartile & 16.4 & 129.1 & 261.5 & 7.9 & 10.4 & 72.8 & 35.3 \\
\hline & & maximum & 17.9 & 171.3 & 544.7 & 29.6 & 99.9 & 100.0 & 77.6 \\
\hline & & mean & 15.3 & 123.9 & 207.9 & 7.0 & 11.4 & 59.6 & 25.9 \\
\hline & & range & 5.5 & 64.3 & 492.4 & 28.2 & 99.9 & 99.9 & 77.6 \\
\hline \multirow[t]{7}{*}{ Raleigh } & \multirow{7}{*}{$\begin{array}{l}\text { EUSE } \\
\text { watersheds } \\
(\text { count }=30)\end{array}$} & minimum & 14.3 & 115.0 & 89.3 & 2.9 & 3.0 & 1.1 & 0.2 \\
\hline & & 1st quartile & 14.6 & 118.2 & 139.9 & 4.7 & 18.7 & 16.7 & 4.1 \\
\hline & & median & 14.9 & 118.8 & 176.3 & 5.1 & 54.4 & 32.2 & 12.0 \\
\hline & & 3rd quartile & 15.3 & 120.0 & 210.4 & 6.3 & 78.3 & 55.8 & 17.2 \\
\hline & & maximum & 15.5 & 125.3 & 284.0 & 8.8 & 98.4 & 81.1 & 41.4 \\
\hline & & mean & 14.9 & 119.2 & 180.0 & 5.4 & 50.3 & 35.7 & 13.1 \\
\hline & & range & 1.2 & 10.4 & 194.7 & 5.9 & 95.4 & 80.0 & 41.2 \\
\hline \multirow{7}{*}{$\begin{array}{l}\text { Northeastern } \\
\text { Coastal Zone }\end{array}$} & \multirow{7}{*}{$\begin{array}{l}\text { Ecoregion } \\
\text { watersheds } \\
(\text { count=313) }\end{array}$} & minimum & 7.2 & 98.0 & 10.0 & 1.6 & 3.8 & 3.4 & 0.0 \\
\hline & & 1st quartile & 8.5 & 120.9 & 49.2 & 4.3 & 9.5 & 38.9 & 4.5 \\
\hline & & median & 9.3 & 124.3 & 85.3 & 5.8 & 17.4 & 53.2 & 7.4 \\
\hline & & 3rd quartile & 10.0 & 130.1 & 136.6 & 7.1 & 35.5 & 66.5 & 11.5 \\
\hline & & maximum & 12.0 & 139.6 & 288.7 & 12.1 & 93.5 & 84.8 & 62.9 \\
\hline & & mean & 9.2 & 124.5 & 99.2 & 5.9 & 25.0 & 51.1 & 9.7 \\
\hline & & range & 4.8 & 41.6 & 278.8 & 10.5 & 89.6 & 81.4 & 62.9 \\
\hline \multirow[t]{7}{*}{ Boston } & \multirow{7}{*}{$\begin{array}{l}\text { EUSE } \\
\text { watersheds } \\
(\text { count=30) }\end{array}$} & minimum & 7.3 & 115.4 & 30.9 & 2.9 & 0.9 & 16.2 & 1.9 \\
\hline & & 1st quartile & 8.1 & 120.6 & 64.4 & 4.8 & 3.7 & 42.2 & 4.2 \\
\hline & & median & 8.8 & 122.5 & 104.6 & 5.9 & 19.9 & 54.9 & 6.6 \\
\hline & & 3rd quartile & 9.4 & 126.0 & 150.0 & 7.3 & 37.8 & 75.5 & 9.4 \\
\hline & & maximum & 9.9 & 136.2 & 236.3 & 8.4 & 76.4 & 85.0 & 12.8 \\
\hline & & mean & 8.7 & 123.2 & 112.7 & 5.9 & 24.0 & 56.6 & 6.8 \\
\hline & & range & 2.5 & 20.8 & 205.4 & 5.5 & 75.5 & 68.8 & 10.8 \\
\hline
\end{tabular}




\section{Representation of Regional Urban Development Conditions Using a Watershed-Based Gradient Study Design}

Table 4. Distribution within percent development quintile class for the EUSE and Level III ecoregion watersheds.

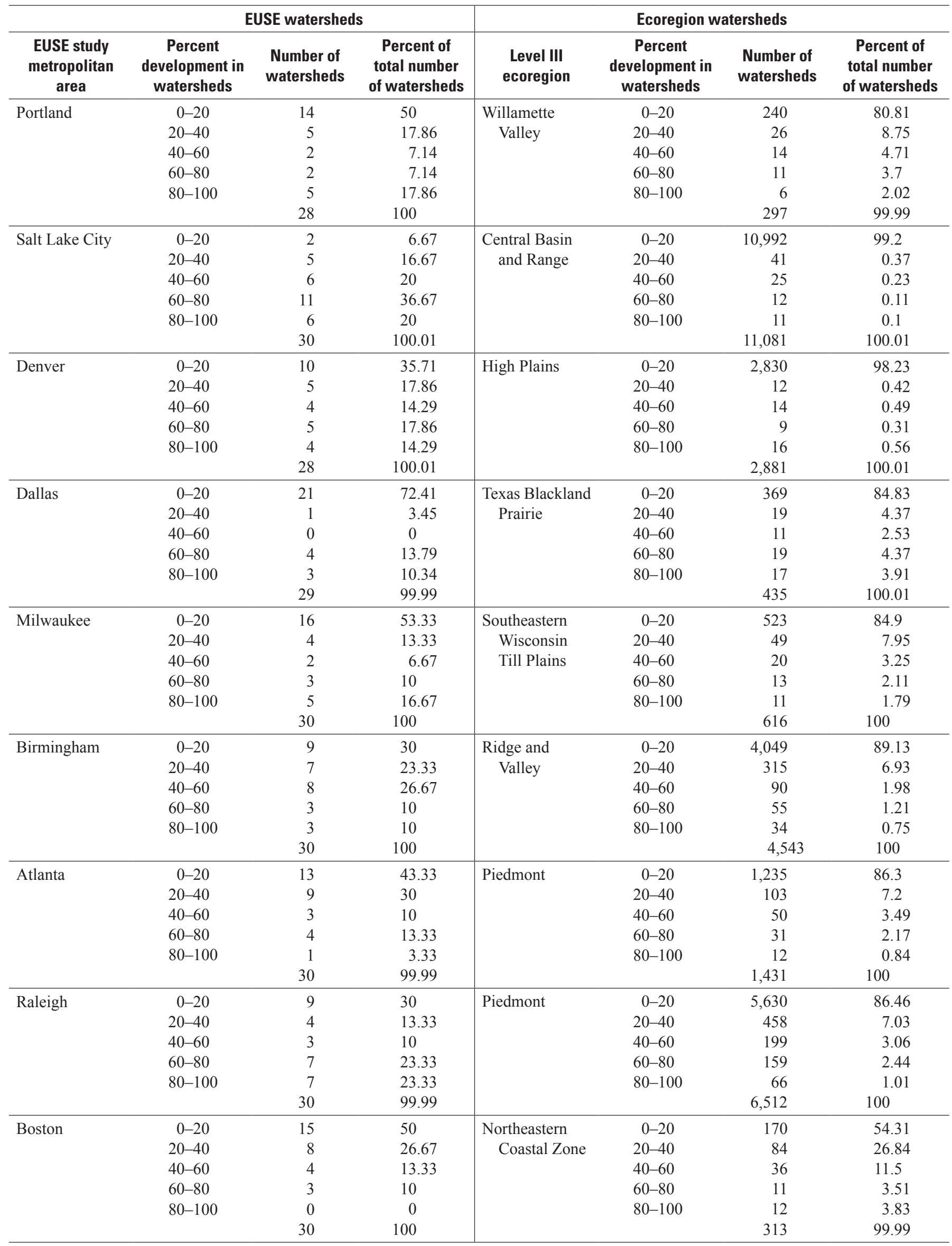




\section{Portland}

The Portland, Oregon, EUSE study area includes 28 watersheds that are located primarily in the Willamette Valley Level III ecoregion (Omernik, 1995; app. 1). This ecoregion is composed of a long river valley, which receives moderate amounts of rainfall, and contains most of Oregon's population and commercial centers. It is also an important agricultural center for the State. Landforms consist of terraces and flood plains that are interlaced and surrounded by rolling hills (Falcone and others, 2007). Soil textures range from fine to medium-coarse. Slope and elevation in the area vary greatly from the lowland valleys to the foothills mountain range. The climate is mild with cool, wet winters and warm, dry summers (McKnight, 2004).

The major metropolitan centers in the area are Portland, Vancouver, Beaverton, Salem, Corvallis, and Eugene with a combined 2000 population of 2.7 million, a 24 percent increase from 1990 (U.S. Census Bureau, 2009). Portland is the dominant commercial center in the study area with extensive port facilities on the Columbia and Willamette
Rivers. The economy includes forestry and timber processing; fruit, wheat, and specialized farming; dairying; food processing; and tourism (McKnight, 2004).

\section{Climate Variables}

The Willamette Valley Level III ecoregion has the smallest area of those in the EUSE study, and climate variability within the ecoregion is small (tables 3 , 5; figs. $4 A, B$; $5 A, B)$. The Portland EUSE watersheds are broadly distributed throughout the ecoregion, thus climate characteristics of the EUSE and ecoregion watersheds are similar. Small portions of the EUSE watersheds are outside the Willamette Valley ecoregion, extending into more mountainous adjacent ecoregions. EUSE watersheds include a lower range of temperature values and a higher range of precipitation values than ecoregion values because the EUSE watersheds include more extreme environments of adjacent ecoregions. The K-W test confirms that there is no significant difference between the EUSE and ecoregion watershed temperature and precipitation characteristics (table 5).

Table 5. Kruskal-Wallis test for similarity between EUSE watersheds and Level III ecoregion watersheds.

[NS = populations are not statistically different at 0.01 significance level; EUSE higher $=$ the median value of the EUSE watersheds is higher than the ecoregion median; EUSE lower = the median value of the EUSE watersheds is lower than the ecoregion median]

\begin{tabular}{|c|c|c|c|c|c|c|c|c|}
\hline $\begin{array}{l}\text { EUSE study } \\
\text { metropolitan } \\
\text { area }\end{array}$ & $\begin{array}{l}\text { Level III } \\
\text { ecoregion }\end{array}$ & $\begin{array}{c}\text { Average } \\
\text { annual } \\
\text { temperature, } \\
\text { degrees } \\
\text { Celsius }\end{array}$ & $\begin{array}{c}\text { Average } \\
\text { annual } \\
\text { precipitation, } \\
\text { centimeters }\end{array}$ & $\begin{array}{c}\text { Average } \\
\text { elevation, } \\
\text { meters }\end{array}$ & $\begin{array}{l}\text { Average } \\
\text { watershed } \\
\text { percent } \\
\text { slope }\end{array}$ & $\begin{array}{c}\text { Percent } \\
\text { developed }\end{array}$ & $\begin{array}{c}\text { Percent } \\
\text { forest }\end{array}$ & $\begin{array}{c}\text { Percent } \\
\text { agriculture }\end{array}$ \\
\hline Portland & $\begin{array}{c}\text { Willamette } \\
\text { Valley }\end{array}$ & NS & NS & NS & NS & NS & NS & EUSE lower \\
\hline Denver & High Plains & EUSE lower & EUSE lower & EUSE higher & EUSE higher & EUSE higher & EUSE higher & EUSE lower \\
\hline Dallas & $\begin{array}{l}\text { Texas } \\
\text { Blackland } \\
\text { Prairie }\end{array}$ & EUSE lower & NS & NS & NS & NS & NS & NS \\
\hline Birmingham & $\begin{array}{c}\text { Ridge and } \\
\text { Valley }\end{array}$ & EUSE higher & EUSE higher & EUSE lower & NS & EUSE higher & EUSE lower & EUSE lower \\
\hline Atlanta & Piedmont & EUSE higher & EUSE higher & EUSE higher & NS & EUSE higher & EUSE lower & EUSE lower \\
\hline Raleigh & Piedmont & NS & NS & NS & EUSE lower & EUSE higher & EUSE lower & EUSE lower \\
\hline Boston & $\begin{array}{c}\text { Northeastern } \\
\text { Coastal } \\
\text { Zone }\end{array}$ & EUSE lower & NS & NS & NS & NS & NS & NS \\
\hline
\end{tabular}



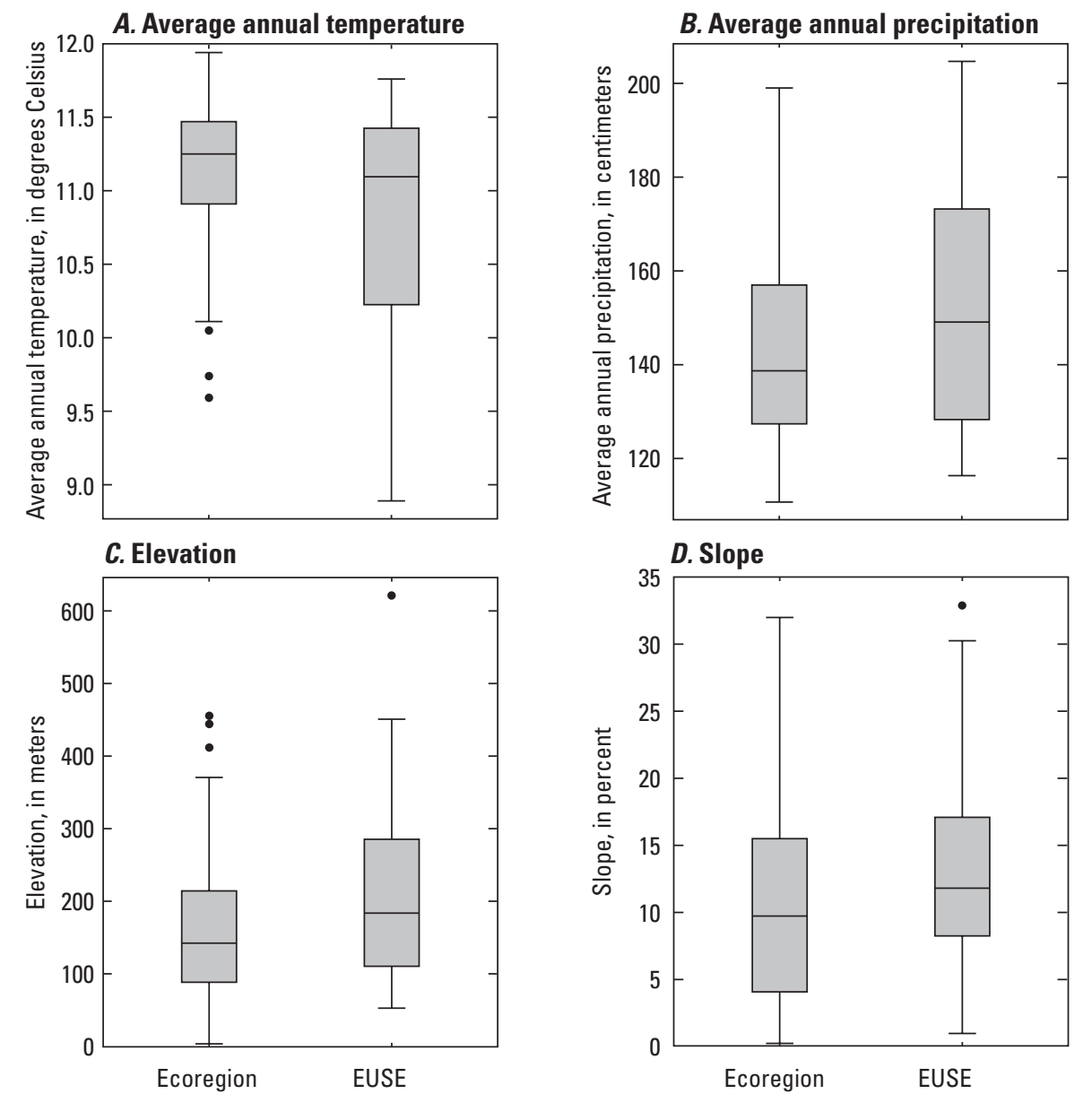

\section{EXPLANATION}

- Outlier

1.5 times the interquartile range above the box

75th percentile Median Interquartile $25^{\text {th }}$ percentile range

1.5 times the interquartile range below the box

- Outlier

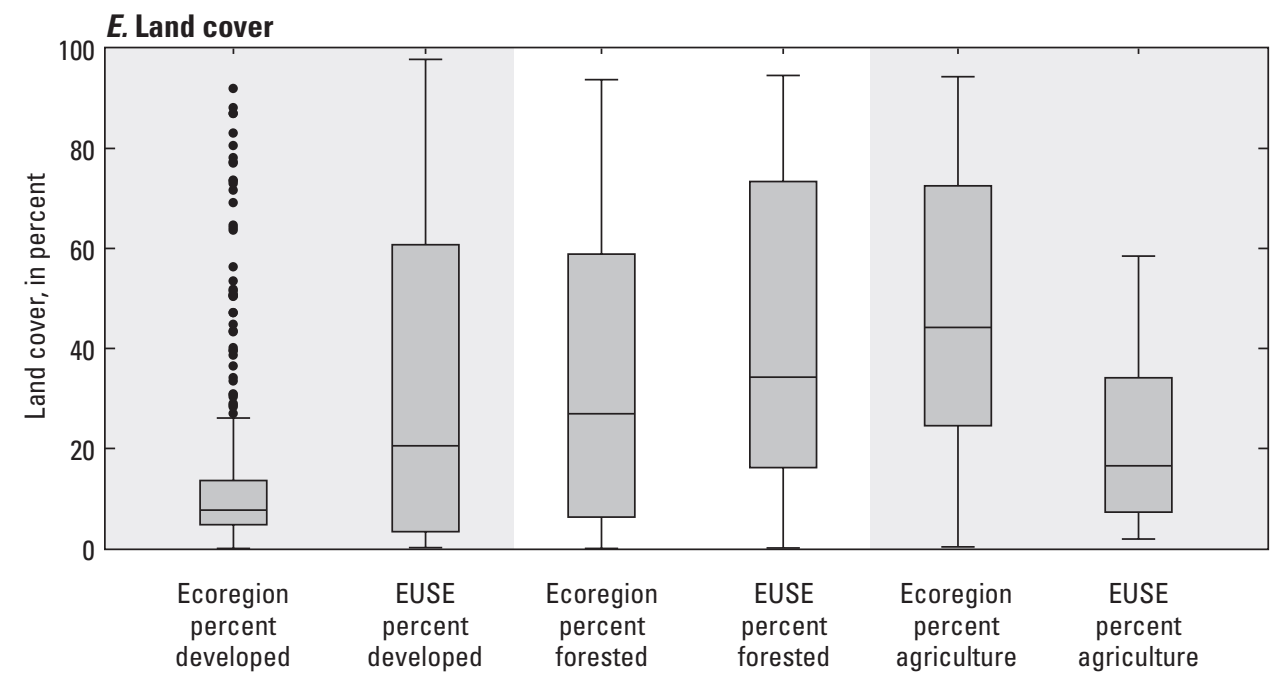

Figure 4. Summary of Willamette Valley Level III ecoregion and Portland EUSE watershed characteristics, including $(A)$ average annual temperature, $(B)$ average annual precipitation, $(C)$ elevation, $(D)$ percent slope, and $(E)$ percent land cover. 
A

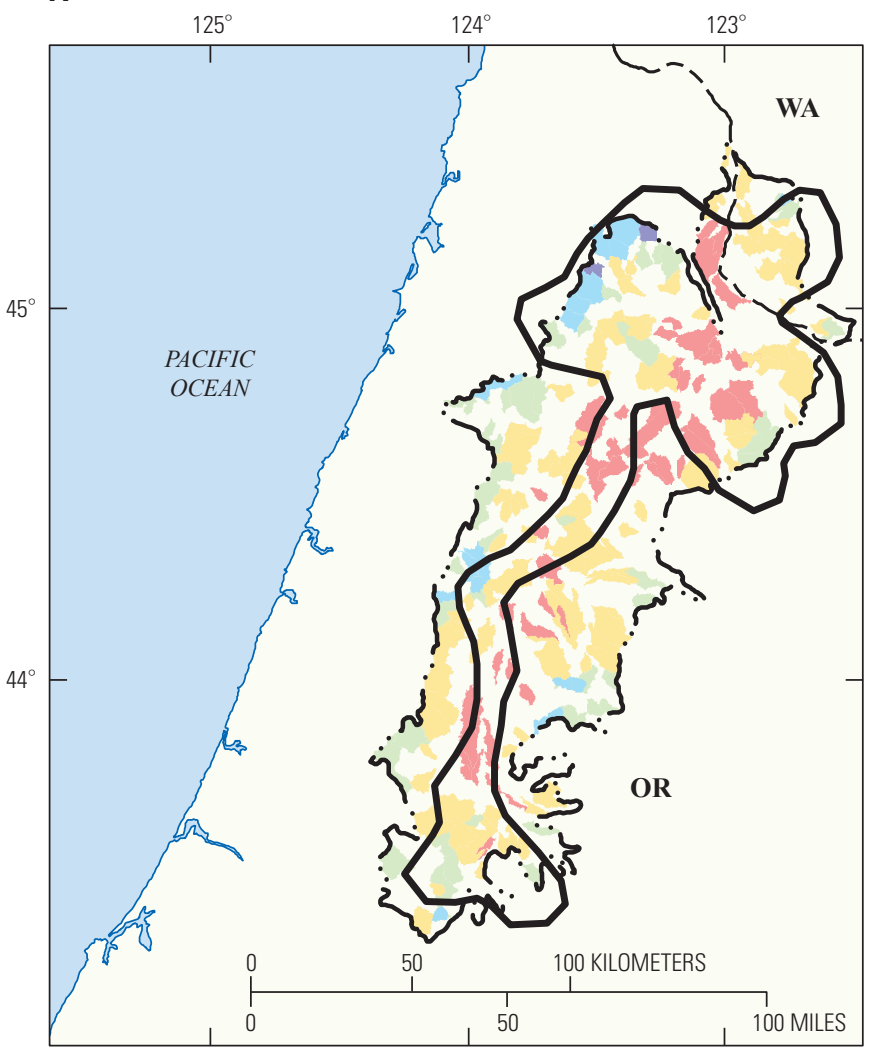

Base from U.S. Census Bureau 2000 U.S. State boundary file, 1:100,000-scale digital data
B

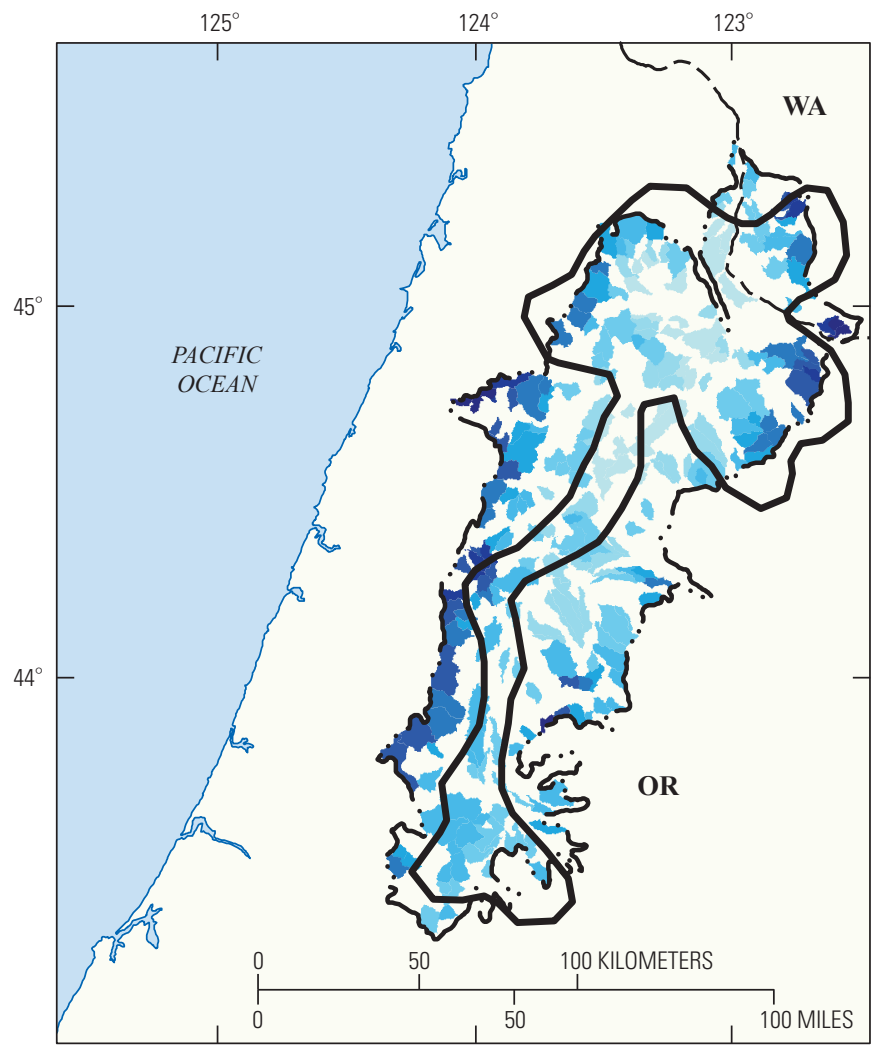

Base from U.S. Census Bureau, 2000 U.S. State boundary file, 1:100,000-scale digital data

\section{EXPLANATION}

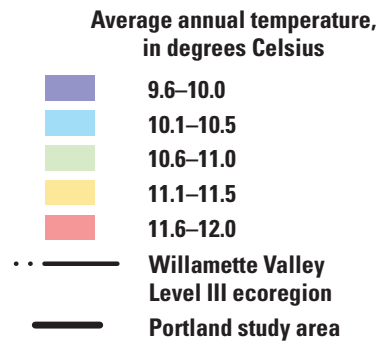

EXPLANATION

Average annual precipitation,

in centimeters

111.1-120.0

120.1-130.0

130.1-140.0

140.1-150.0

150.1-160.0

160.1-170.0

170.1-180.0

180.1-190.0

190.1-200.0

Willamette Valley Level III ecoregion

Portland study area

Figure 5. Summary of Willamette Valley Level III ecoregion watershed characteristics, including $(A)$ average annual temperature, $(B)$ average annual precipitation, $(C)$ elevation, $(D)$ average slope, $(E)$ developed land cover, $(F)$ forested land cover, and $(G)$ agricultural land cover. 
$\boldsymbol{C}$
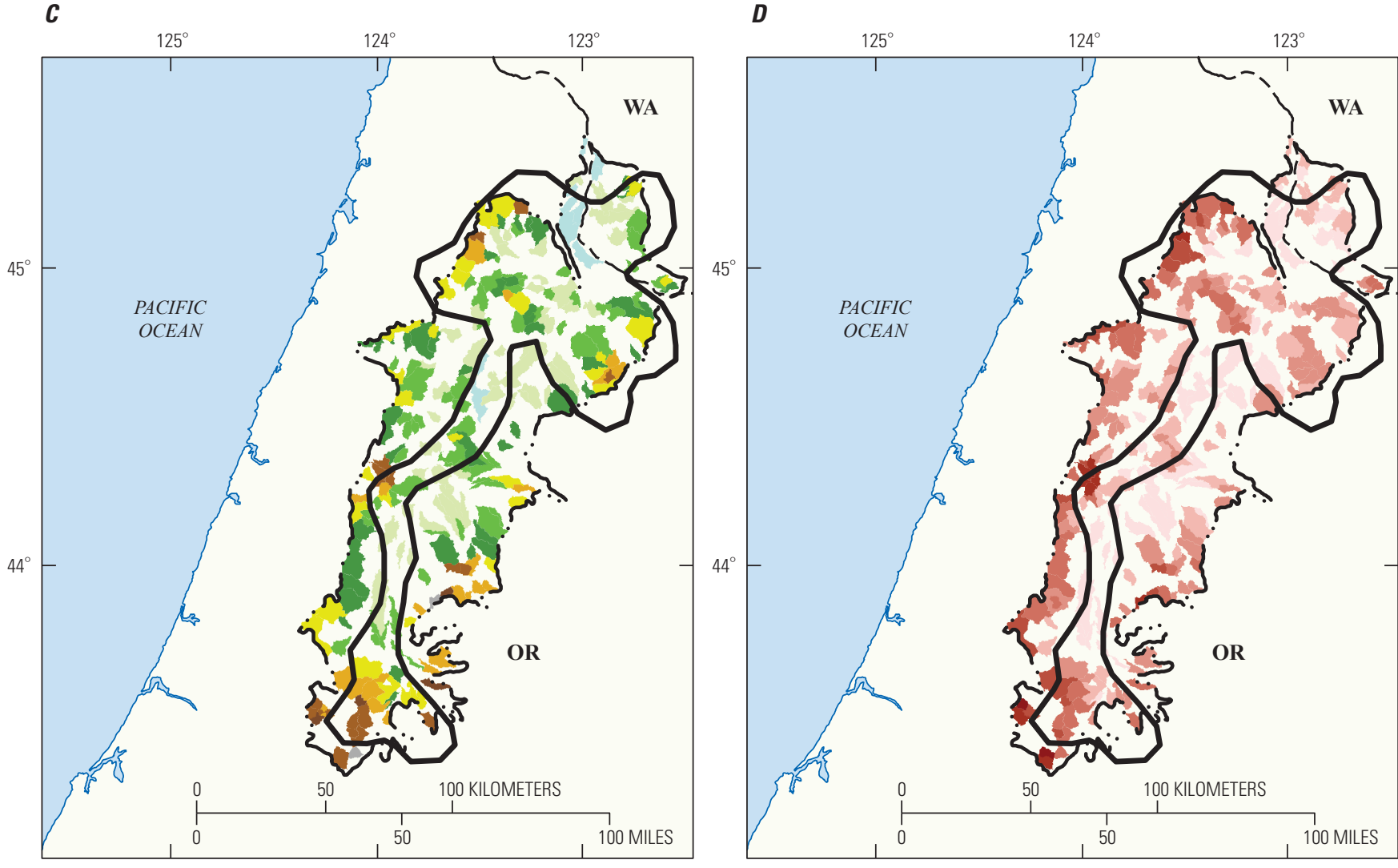

Base from U.S. Census Bureau, 2000 U.S. State boundary file,

1:100,000-scale digital data

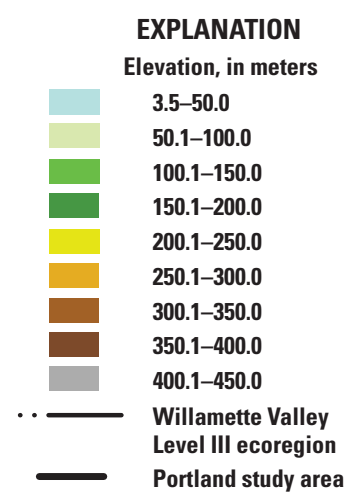

Base from U.S. Census Bureau, 2000 U.S. State boundary file, 1:100,000-scale digital data

Figure 5-Continued. Summary of Willamette Valley Level III ecoregion watershed characteristics, including $(A)$ average annual temperature, $(B)$ average annual precipitation, $(C)$ elevation, $(D)$ average slope, $(E)$ developed land cover, $(F)$ forested land cover, and (G) agricultural land cover. 
E

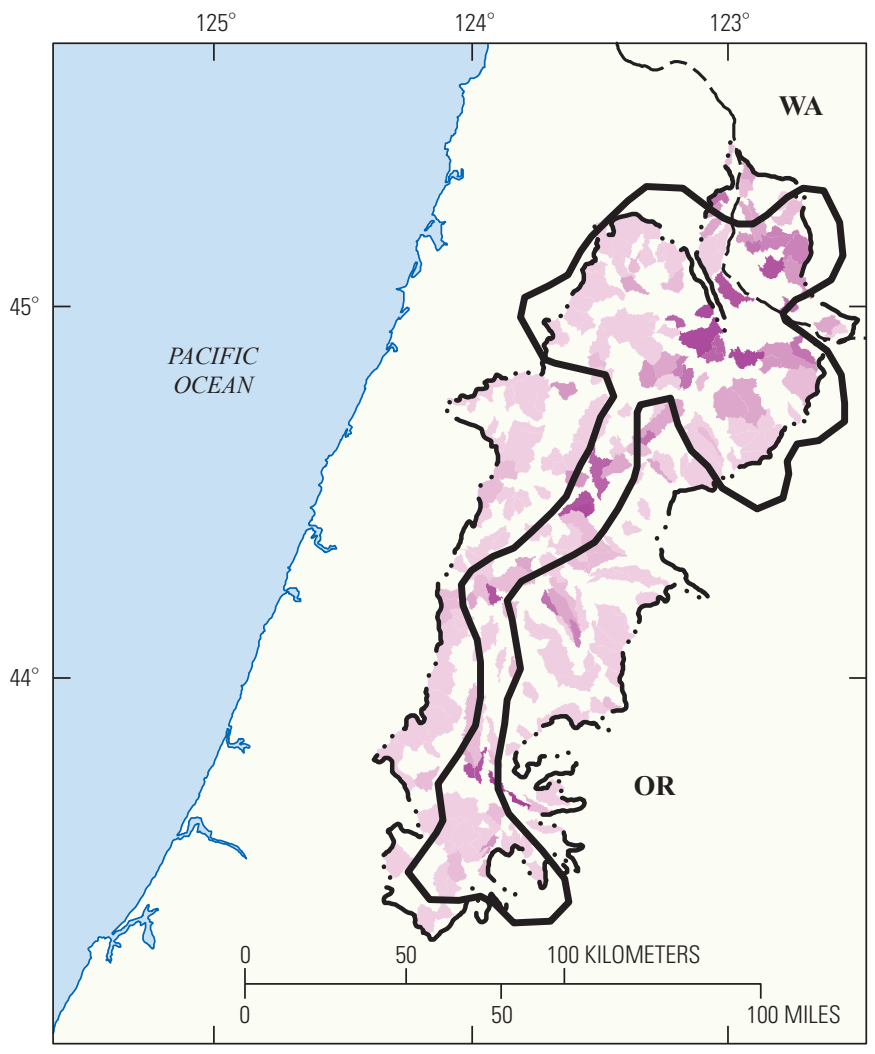

Base from U.S. Census Bureau, 2000 U.S. State boundary file,

1:100,000-scale digital data
$\boldsymbol{F}$

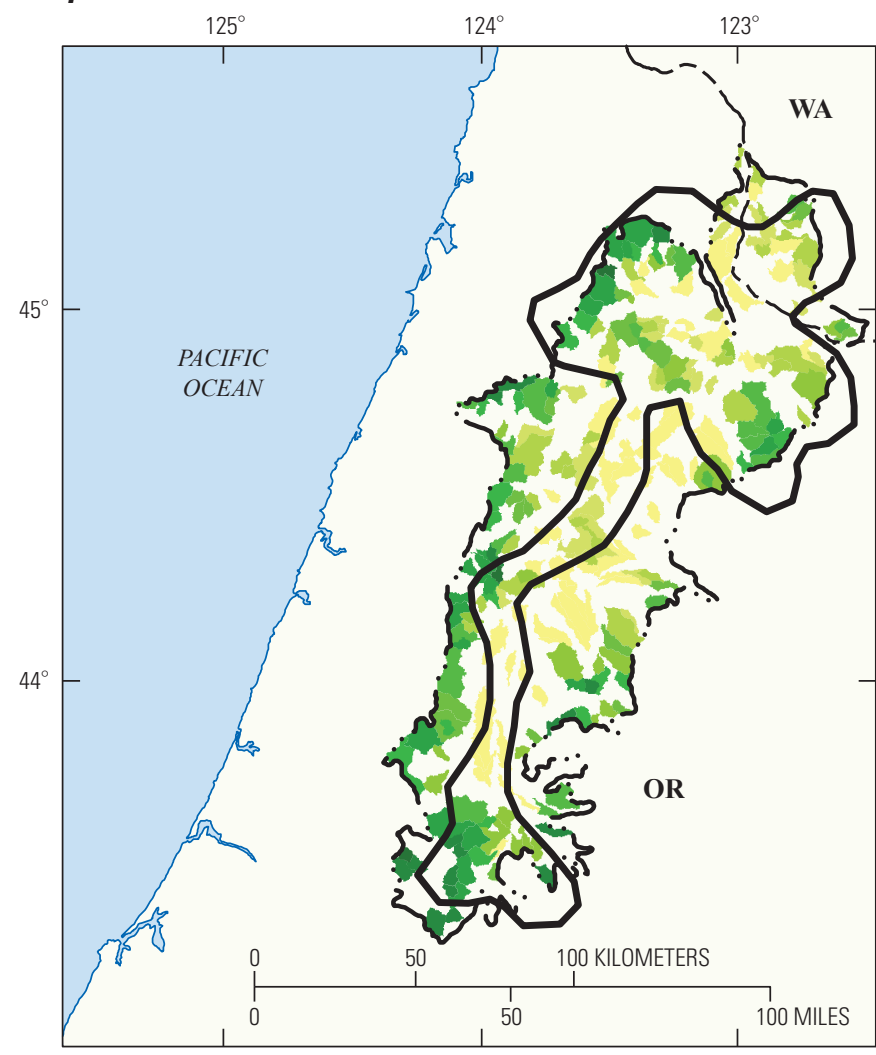

Base from U.S. Census Bureau, 2000 U.S. State boundary file,

1:100,000-scale digital data
EXPLANATION

Developed land cover, in percent

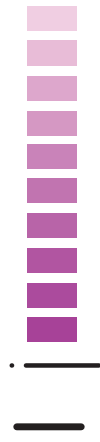

0-10.0

10.1-20.0

20.1-30.0

$30.1-40.0$

40.1-50.0

50.1-60.0

60.1-70.0

70.1-80.0

80.1-90.0

90.1-100.0

Willamette Valley

Level III ecoregion

Portland study area
EXPLANATION

Forested land cover, in percent

0-10.0

10.1-20.0

20.1-30.0

$30.1-40.0$

$40.1-50.0$

50.1-60.0

60.1-70.0

70.1-80.0

80.1-90.0

90.1-100.0

Willamette Valley

Level III ecoregion

Portland study area

Figure 5-Continued. Summary of Willamette Valley Level III ecoregion watershed characteristics, including $(A)$ average annual temperature, $(B)$ average annual precipitation, $(C)$ elevation, $(D)$ average slope, $(E)$ developed land cover, $(F)$ forested land cover, and $(G)$ agricultural land cover. 


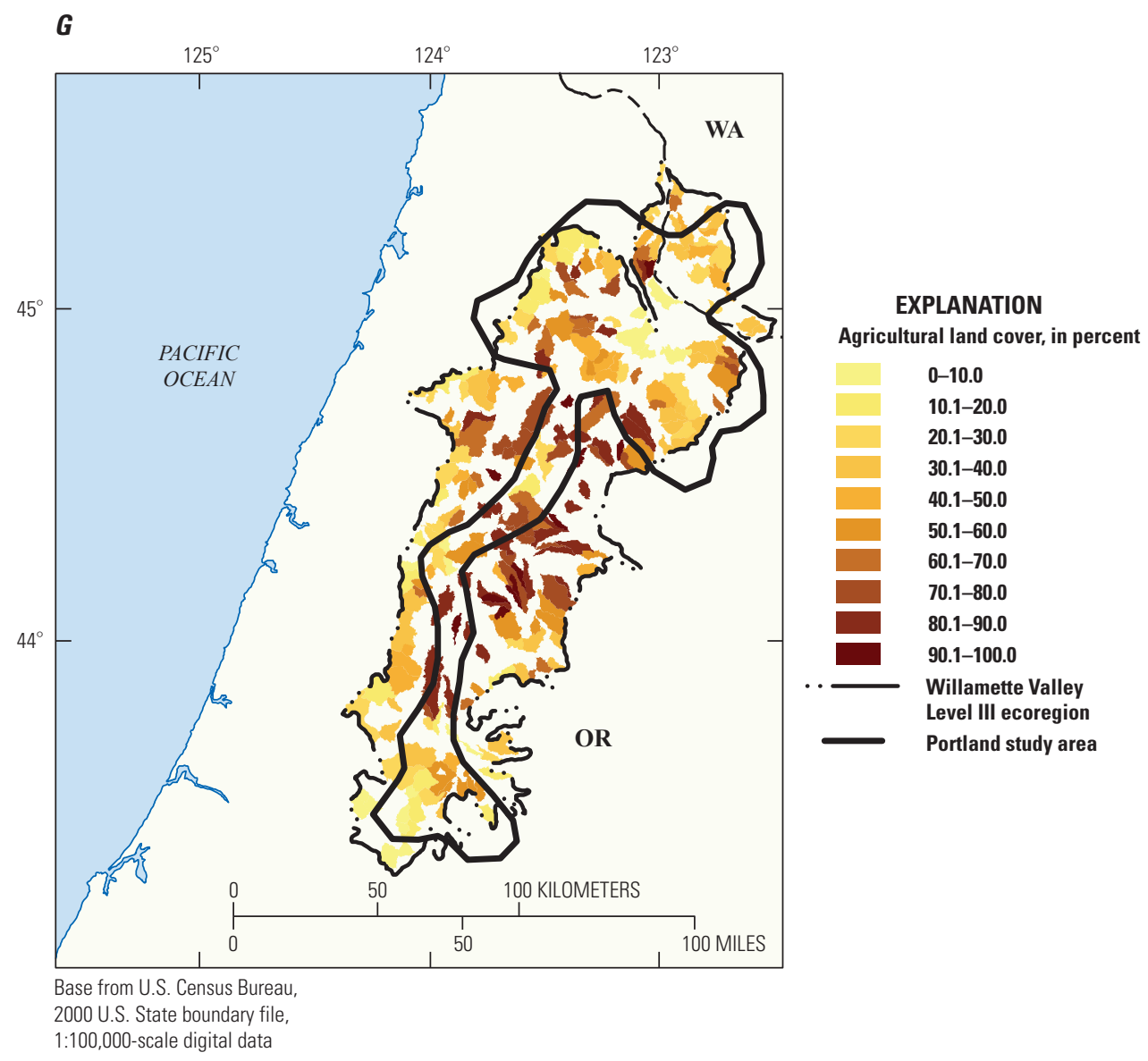

Figure 5-Continued. Summary of Willamette Valley Level III ecoregion watershed characteristics, including $(A)$ average annual temperature, $(B)$ average annual precipitation, $(C)$ elevation, $(D)$ average slope, $(E)$ developed land cover, $(F)$ forested land cover, and $(G)$ agricultural land cover.

The development classes also reflect the wide range of climate conditions (fig. $6 A, B$ ). The most extreme temperatures and precipitation amounts are seen in the watersheds with the lowest level of development (first quintile; table 4). For both the Portland EUSE and the Willamette Valley ecoregion watersheds, the watersheds with the lowest average annual temperature and the highest precipitation amounts (including heavy snowfall in the winter) are in the 0-20 percent development class. Other development classes are clustered in the higher mean annual temperature ranges and lower mean annual precipitation ranges, suggesting that the areas with the lowest temperature and highest precipitation ranges are not as suitable for development, but the climate does not seem to affect other development classes.

\section{Topographic Variables}

The median elevation and slope values of the Willamette Valley ecoregion watersheds are slightly lower than those of the Portland EUSE watersheds (tables 3, 5; fig. 4C, D). Because some of the EUSE watersheds overlap into adjacent ecoregions, the range of elevation and slope values of the EUSE watersheds includes somewhat higher values than those of the ecoregion as a whole because of discrepancies between the EUSE and ecoregion watershed boundaries. The K-W results indicate that there is no statistically significant difference between the EUSE study and the ecoregion watersheds in terms of elevation and slope values. As with the climate variables, greater variation in topographic characteristics is seen in the lowest quintile of development (fig. $6 C, D$ ). 

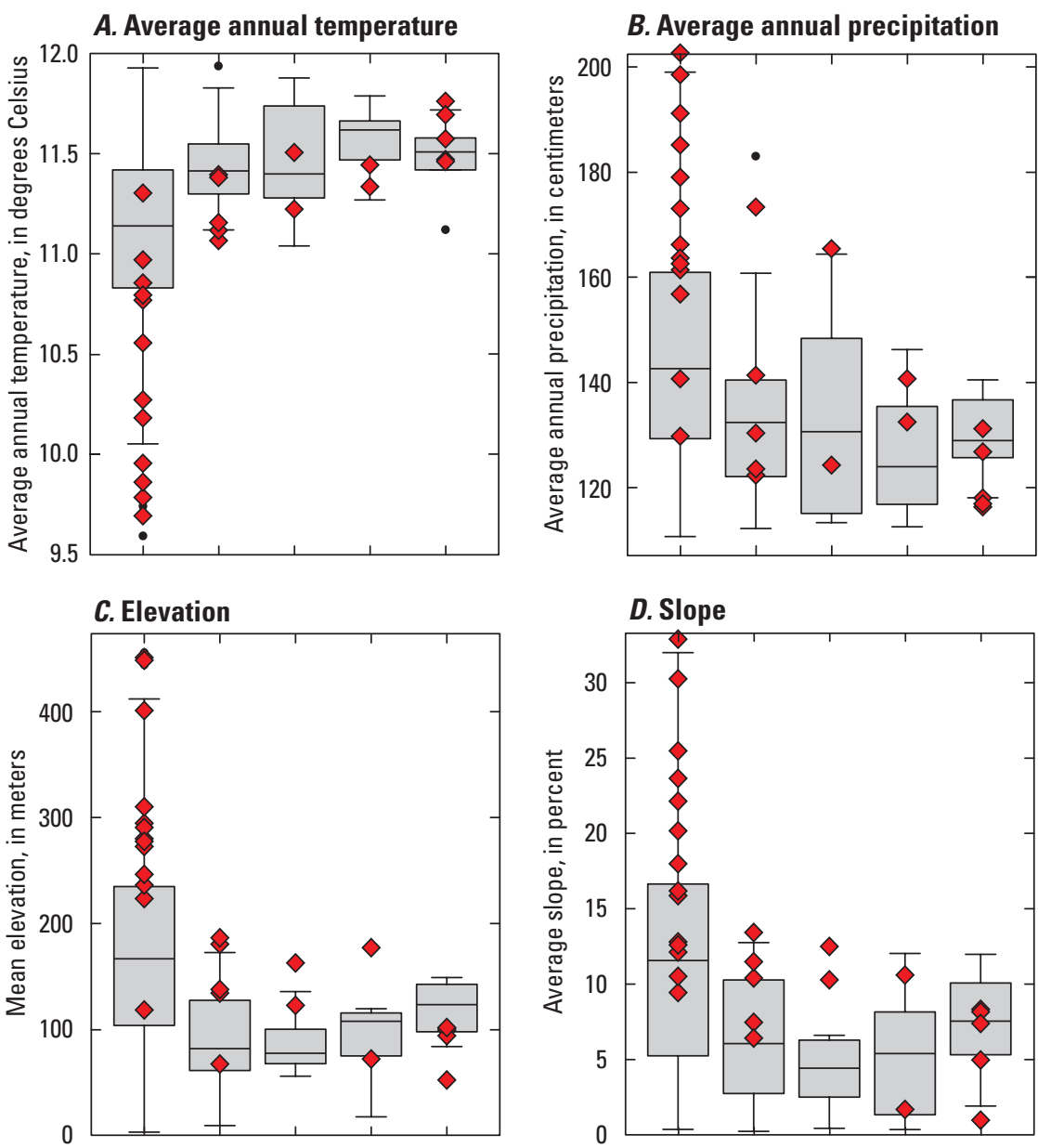

\section{EXPLANATION}

- Outlier

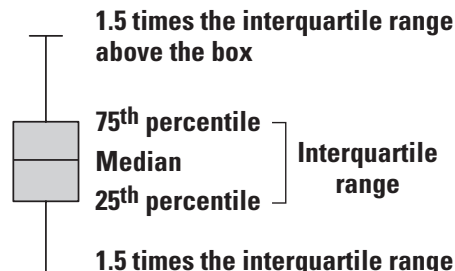

1.5 times the interquartile range below the box

$\diamond \quad$ EUSE values within development class
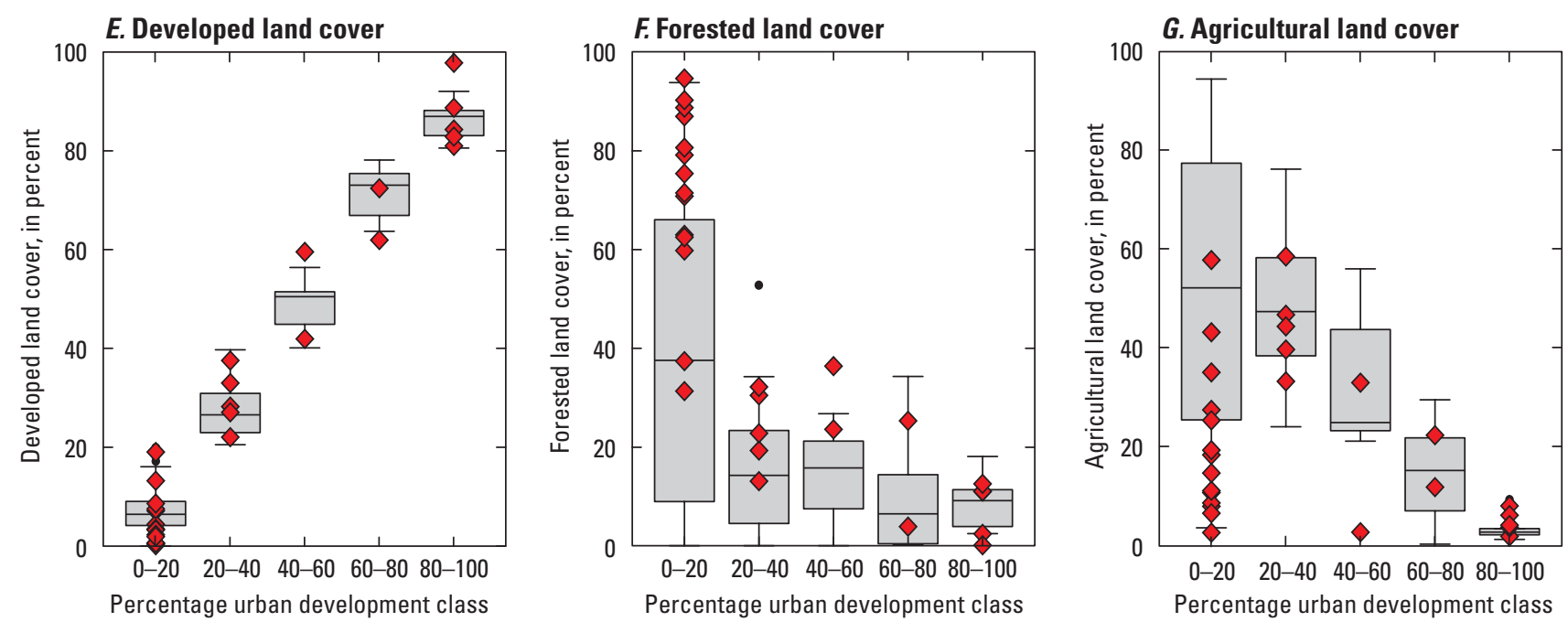

Figure 6. Summary of Willamette Valley Level III ecoregion and Portland EUSE study watershed characteristics by percentage of urban development class. $A$, Average annual temperature. $B$, Average annual precipitation. $C$, Mean elevation. $D$, Average slope. E, Developed land cover. F, Forested land cover. G, Agricultural land cover. 


\section{Land-Cover Variables}

The range of developed land percentages represented by the Portland EUSE watersheds is similar to that of the Willamette Valley ecoregion watersheds, although the median amount of developed land in the EUSE watersheds is higher than that in the ecoregion watersheds (tables 3,5 ; figs. $4 E$, $7 A$ ). Figure 7 shows the cumulative distribution of the amount of developed land in the ecoregion watersheds (blue line) and the amount of developed land in the EUSE watersheds (red squares; see sidebar, p. 7). The range of developed land cover in EUSE watersheds reflects the range in the overall ecoregion watersheds, except for a small gap in coverage of EUSE watersheds having between 40 and 50 percent developed land. The K-W test indicates that there is no difference between the EUSE and the ecoregion watersheds in the distribution of developed land cover in the watersheds.

The distribution of forest and shrubland is similar between the Portland EUSE and the Willamette Valley ecoregion watersheds, although the median amount of forested land is slightly higher in the EUSE watersheds (figs. $4 E, 6 F$ ). The amount of forested land cover in the EUSE watersheds reflects the distribution of the overall population of watersheds, except for a small gap in coverage of watersheds having between 40 and 60 percent developed land (fig. $7 B$ ). The K-W test indicates that there is no difference between the EUSE and the ecoregion watersheds in the distribution of forested land cover.

The Portland EUSE watersheds under represent the amount of herbaceous and cultivated land cover in the Willamette Valley ecoregion watersheds (figs. 4E, 6G). The median value for the EUSE watersheds is 17 percent and for the ecoregion watersheds is 44 percent (table 3 ). The maximum value for the EUSE watersheds of 59 percent is considerably lower than the ecoregion maximum value of 94 percent. The lowest developed watersheds have the widest range of agricultural land cover (fig. $6 G$ ), but the EUSE watersheds have a considerably lower degree of agricultural land cover than the ecoregion within this development class. The third quintile of development for EUSE sites (40-60 percent developed) is also considerably less for agricultural land cover than the third quintile for the ecoregion watersheds (table 3).

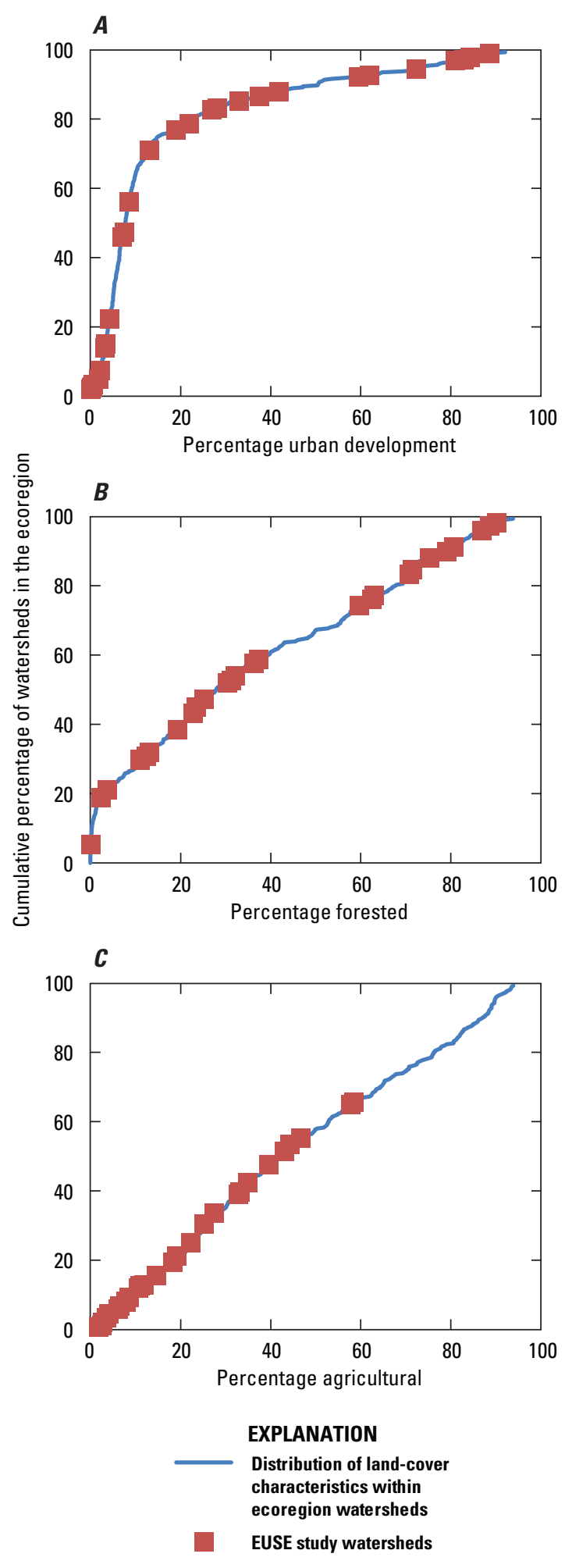

Figure 7. Cumulative distribution plot (blue line) of the percentage of $(A)$ urban development, $(B)$ forested, and $(C)$ agricultural land cover in the Willamette Valley Level III ecoregion watersheds, and the percentage of the same land-cover types in the Portland EUSE study watersheds. 


\section{Salt Lake City}

The 30 Salt Lake City, Utah, EUSE study watersheds are located in the Central Basin and Range Level III ecoregion (app. 1). Because the area around Salt Lake City is so sparsely populated, watersheds are partially located outside of the Central Basin and Range ecoregion, which fulfills the primary EUSE objective of sampling in watersheds in areas of low to high development. It should be noted that portions of the watersheds used for comparison are outside of the Central Basin and Range ecoregion. All sampling locations, however, are within the Central Basin and Range ecoregion.

The majority of this ecoregion is undeveloped, arid land composed of flatlands, low mountains, and high mountains. Shrub and forestland cover most of the ecoregion. The Salt Lake City study watersheds are located in three major river systems: the Bear, the Weber, and the Utah Lake/Jordan River systems. These river systems drain into the Great Salt Lake with no outflow to the ocean. The study area is characterized by cold desert watersheds, scattered low and high mountains, and salt flats. The climate of the study area is semiarid with most of the precipitation occurring as winter snows or occasional summer thunderstorms. The lowland valleys have moderate temperature shifts between winter and summer; whereas the high mountains have long, cold winters and short, cool summers (Baskins and others, 2002).

The Salt Lake City study area includes four main metropolitan areas: Salt Lake City, Logan, Ogden, and Provo. The combined 2000 population was 1.9 million, a 29 percent increase from 1990 (U.S. Census Bureau, 2009). Typical of semiarid urban areas in the western United States, an array of reservoirs, diversions, and canals alters the hydrologic regime of most Salt Lake City streams, and water rights is a continuous area of contention (Baskins and others, 2002). Historically, land use in the study area was grasslands, evergreen forests, and desert shrubs (McKnight, 2004), some of which has been converted to irrigated agriculture and urban areas (Baskins and others, 2002). The economy in the area is largely supported by mining, church, government, finance, education, research, high-technology industries, transportation, recreation, and tourism (McKnight, 2004).

\section{Climate Variables}

The Central Basin and Range Level III ecoregion is the largest area in the EUSE study and includes the largest range of climatic conditions (tables 3 , 5; figs. $8 A, B ; 9 A, B$; $10 A, B)$. The average annual temperature ranges from less than 1 degree Celsius $\left({ }^{\circ} \mathrm{C}\right)$ to $16^{\circ} \mathrm{C}$ within the ecoregion watersheds, the largest variation in the eight study ecoregions. The temperature range for the Salt Lake City EUSE watersheds is much smaller than the range for the Central Basin and Range ecoregion watersheds. The median average annual temperature values of the ecoregion and EUSE watersheds are similar. The least developed watersheds show the most extreme temperature conditions in both the ecoregion and EUSE watersheds (fig. 10A).

The range of average annual precipitation values in the Central Basin and Range Level III ecoregion is also the largest of all the study ecoregions. Overall, this ecoregion is dry, with a median precipitation of 31 centimeters $(\mathrm{cm})$. The EUSE watersheds have a higher median average annual precipitation value than the ecoregion as a whole. Most of the EUSE watersheds are among the outliers for precipitation values among the ecoregion watersheds, and not surprisingly, the K-W test shows that the EUSE and ecoregions watersheds have significantly different distributions for these climate variables. Precipitation is lower in the ecoregion watersheds for all development classes (fig. 10B).

\section{Topographic Variables}

The Central Basin and Range Level III ecoregion has low, gently sloping areas surrounded by higher areas with greater relief (tables 3 , 5; figs. $8 C, D ; 9 C, D ; 10 C, D$ ). The average elevation within the ecoregion watersheds is 1,752 meters $(\mathrm{m})$, over $300 \mathrm{~m}$ higher than the EUSE watersheds. The range of watershed elevation in the ecoregion is much larger than in the EUSE watersheds. The large variation is primarily within the least developed quintile of watersheds; other quintiles are similar in range to the EUSE watersheds. The median percentage slope values for the ecoregion watersheds is close to that of the EUSE watersheds, but the range of slope values is much smaller for the EUSE watersheds. The greatest variation in slope values is primarily in the first quintile of development.

\section{Land-Cover Variables}

The amount of developed land within the Central Basin and Range ecoregion watersheds is very small; the median and third quartile values are less than 0.5 percent (tables 3,5 ; figs. $8 E, 10 E, 11 A$ ). Most of the ecoregion is in public land. The Salt Lake City EUSE watersheds with more than 20 percent developed land include most of the watersheds within the entire ecoregion with this amount of developed land. All values of the EUSE watersheds are among the outliers of the ecoregion watersheds. Among the watersheds with more than 20 percent developed land, values within the quintiles are similarly distributed among the EUSE and ecoregion watersheds (fig. 10E).

Forested and shrubland are the major land-cover types in the Central Basin and Range Level III ecoregion and Salt Lake City EUSE study area. The median percentage forested value for the ecoregion watersheds is 98 percent, with a very broad range, while the EUSE watersheds have a much narrower range of this land-cover type, with a median value of 17 percent forested (figs. $8 E, 9 E, 11 B$ ). The representation of forested and shrubland in the EUSE watersheds is similar to that in the ecoregion in that both have a high proportion of forest and shrubland as the background characteristic 

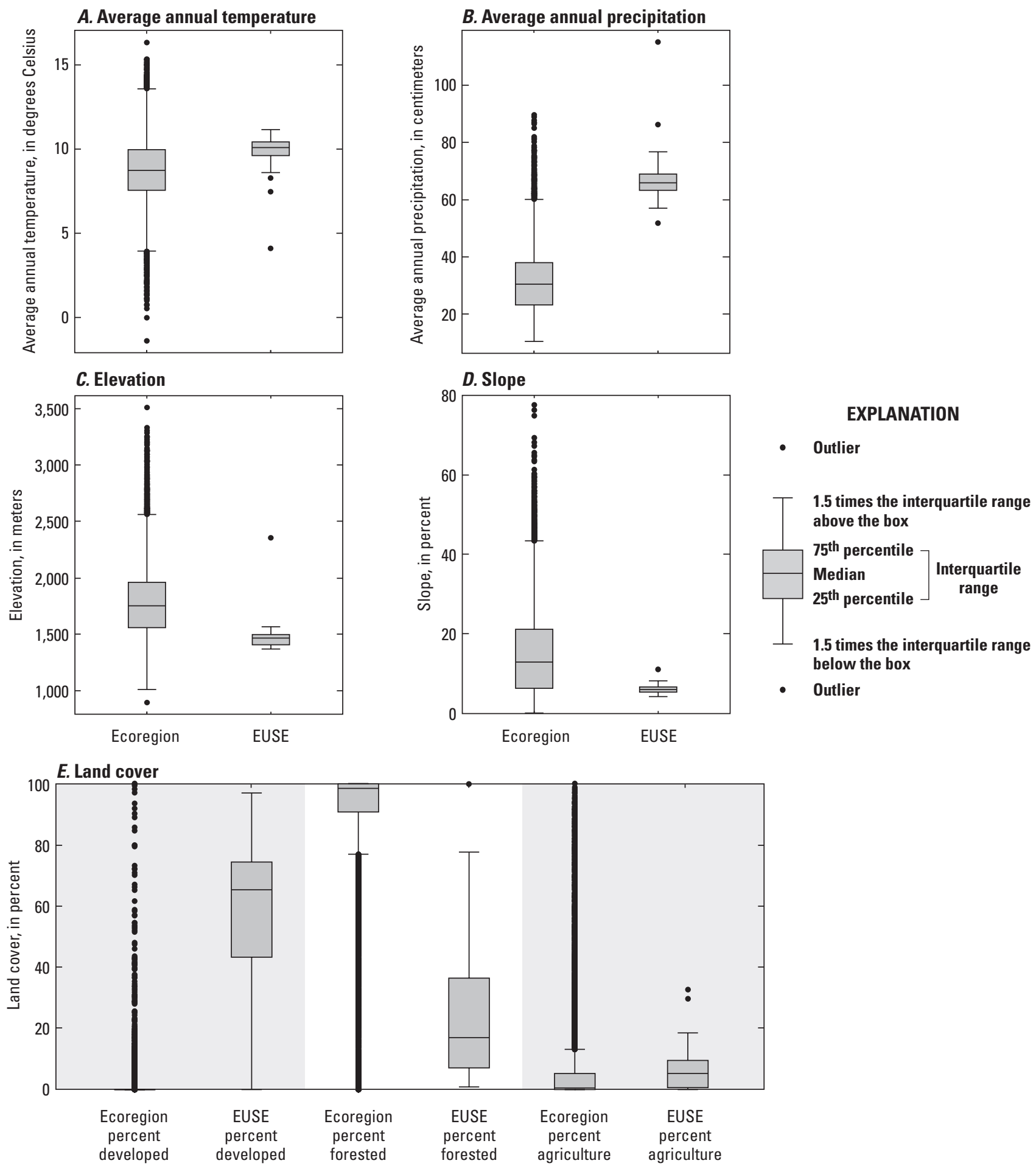

Figure 8. Summary of Central Basin and Range Level III ecoregion and Salt Lake City EUSE study watershed characteristics, including $(A)$ average annual temperature, $(B)$ average annual precipitation, $(C)$ elevation, $(D)$ percent slope, and $(E)$ percent land cover.

within all development classes. Relatively little agricultural land exists in the ecoregion; the median value of herbaceous and cultivated land in the ecoregion watersheds is less than 1 percent, and the EUSE watersheds have a median value of
5 percent (figs. $8 E, 11 C$ ). The amount of agricultural land in the ecoregion as a whole is well represented by the EUSE watersheds. 
A

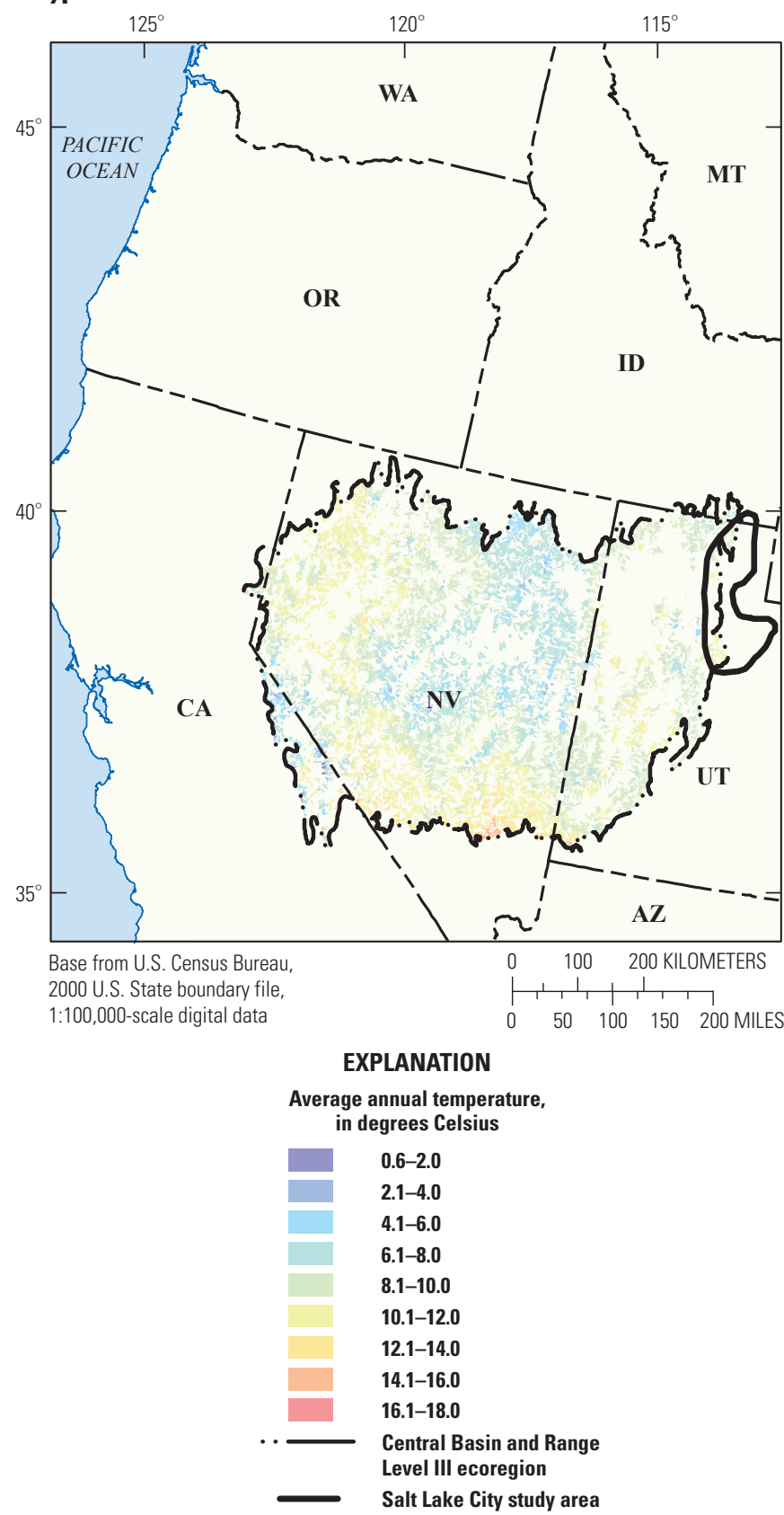

B

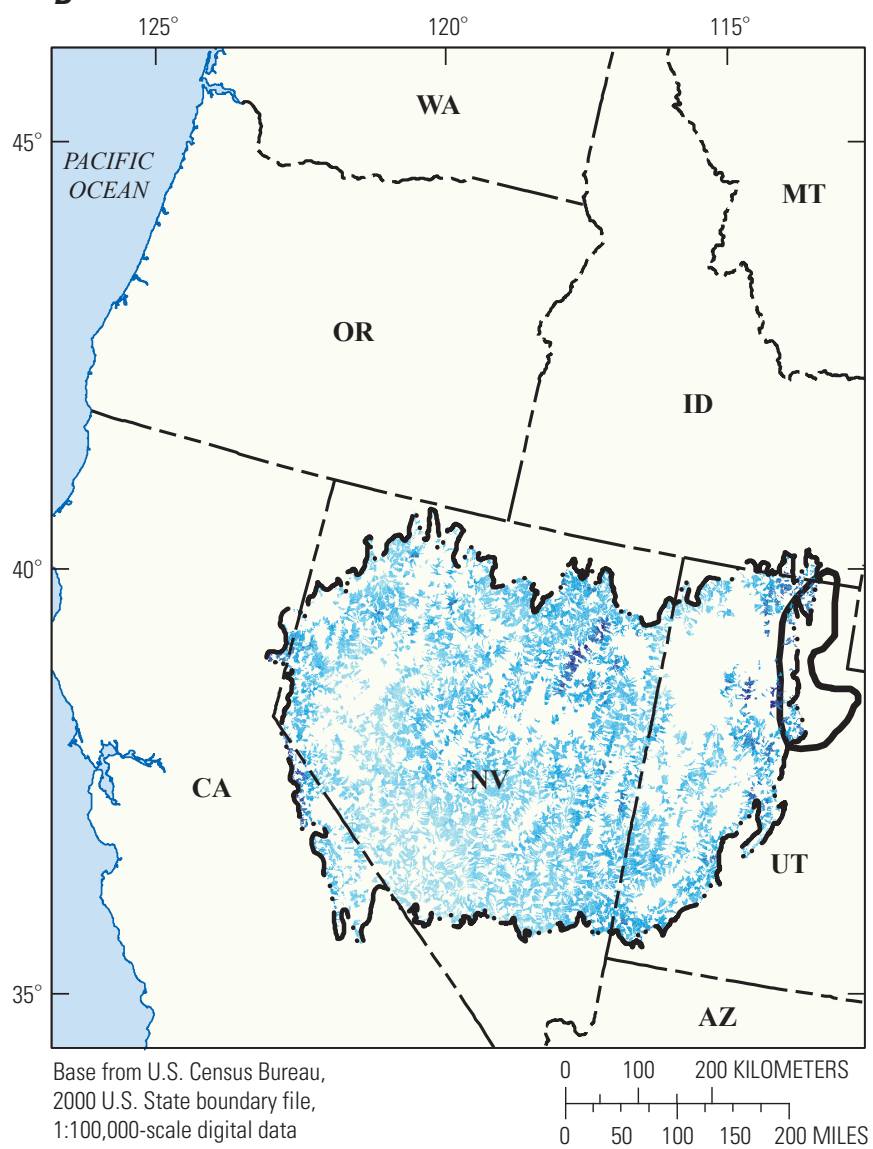

EXPLANATION

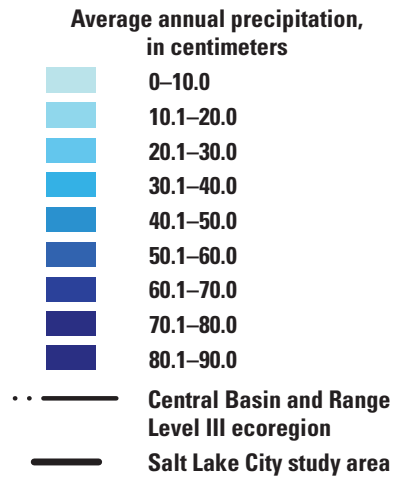

Figure 9. Summary of Central Basin and Range Level III ecoregion watershed characteristics, including $(A)$ average annual temperature, $(B)$ average annual precipitation, $(C)$ elevation, $(D)$ average slope, $(E)$ developed land cover, $(F)$ forested land cover, and $(G)$ agricultural land cover. 
C

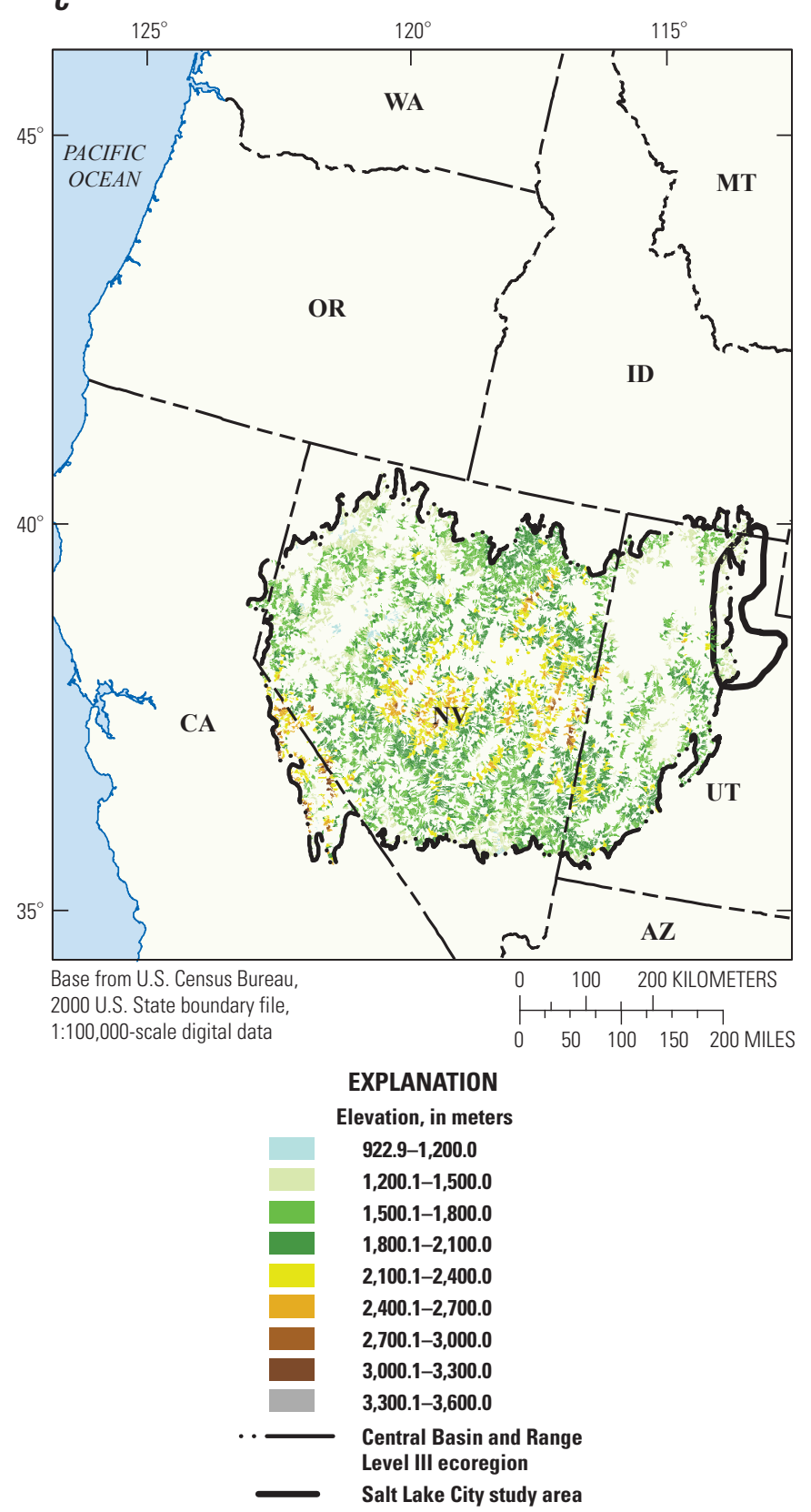

D

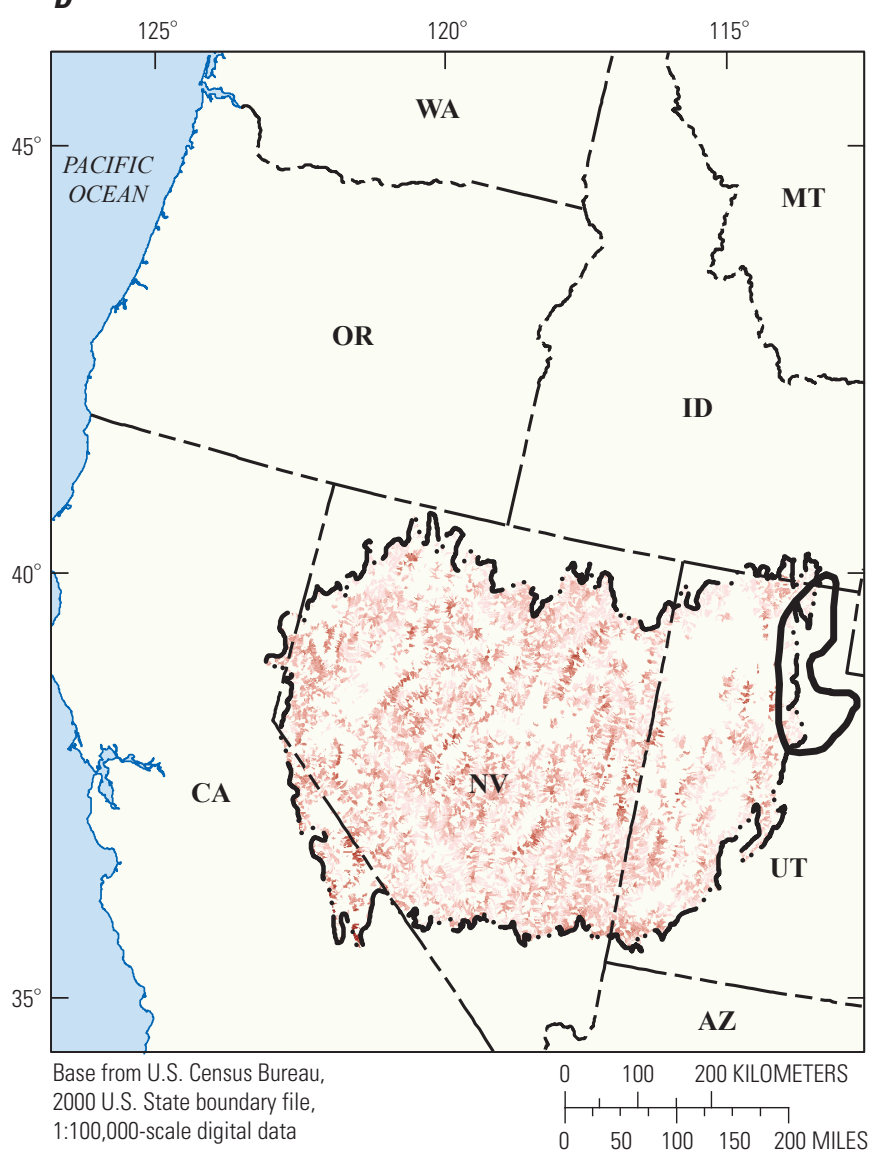

EXPLANATION

Average slope, in percent

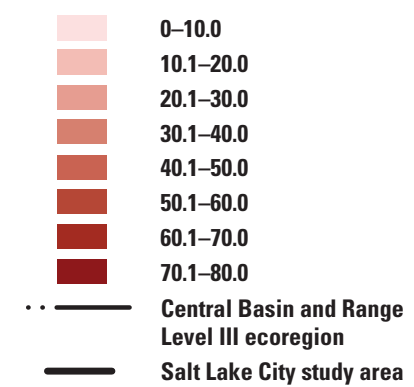

Figure 9-Continued. Summary of Central Basin and Range Level III ecoregion watershed characteristics, including $(A)$ average annual temperature, $(B)$ average annual precipitation, $(C)$ elevation, $(D)$ average slope, $(E)$ developed land cover, $(F)$ forested land cover, and $(G)$ agricultural land cover. 

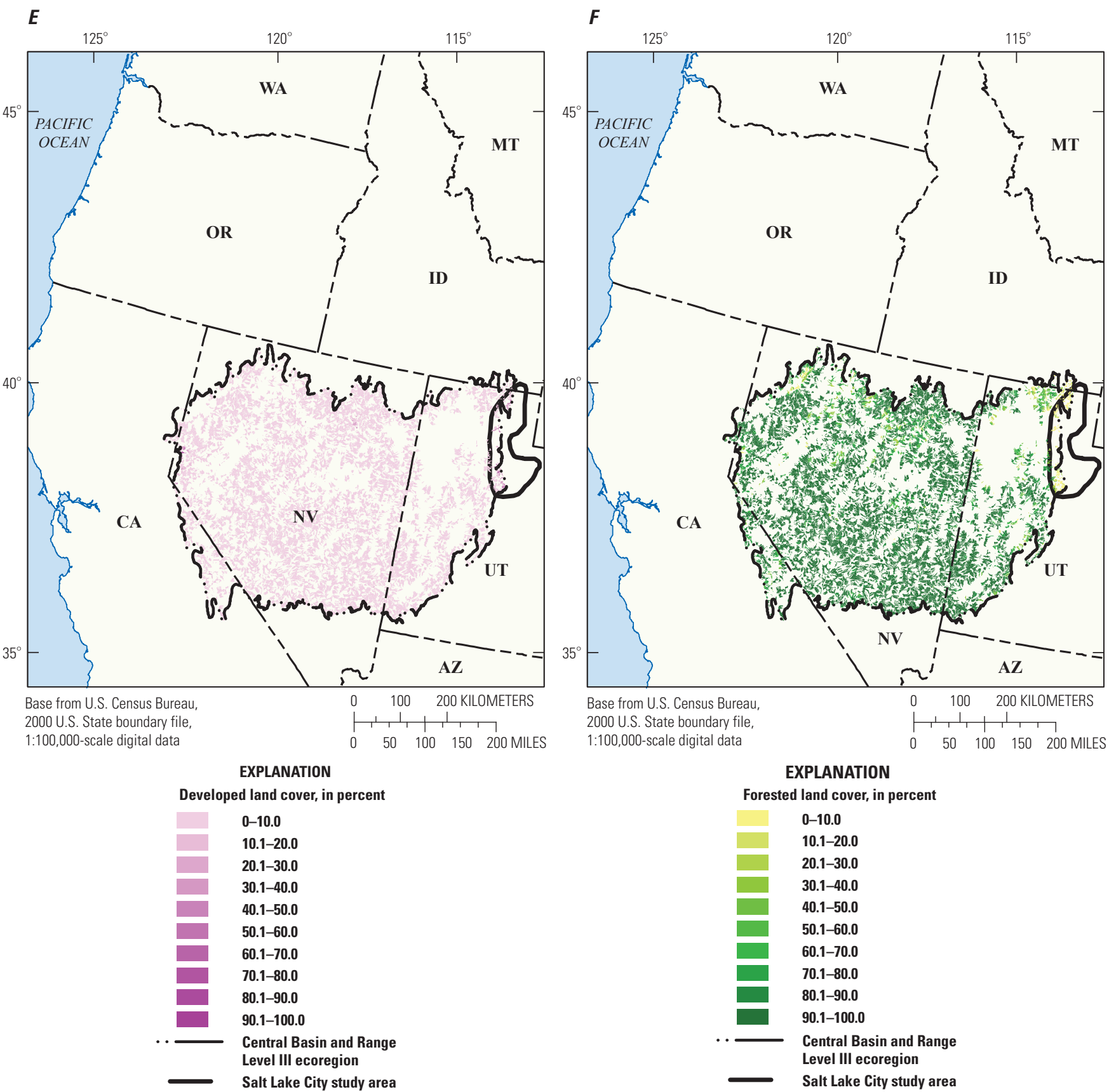
2000 U.S. State boundary file,

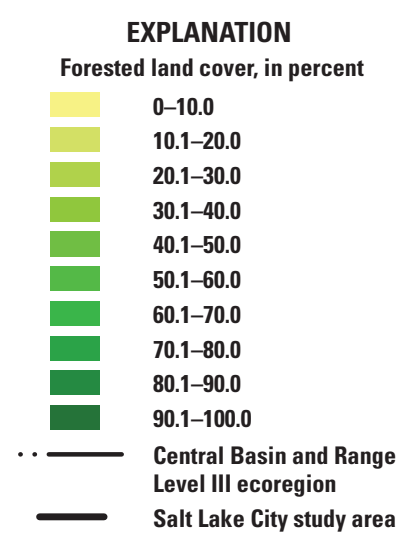

Figure 9-Continued. Summary of Central Basin and Range Level III ecoregion watershed characteristics, including $(A)$ average annual temperature, $(B)$ average annual precipitation, $(C)$ elevation, $(D)$ average slope, $(E)$ developed land cover, $(F)$ forested land cover, and $(G)$ agricultural land cover. 


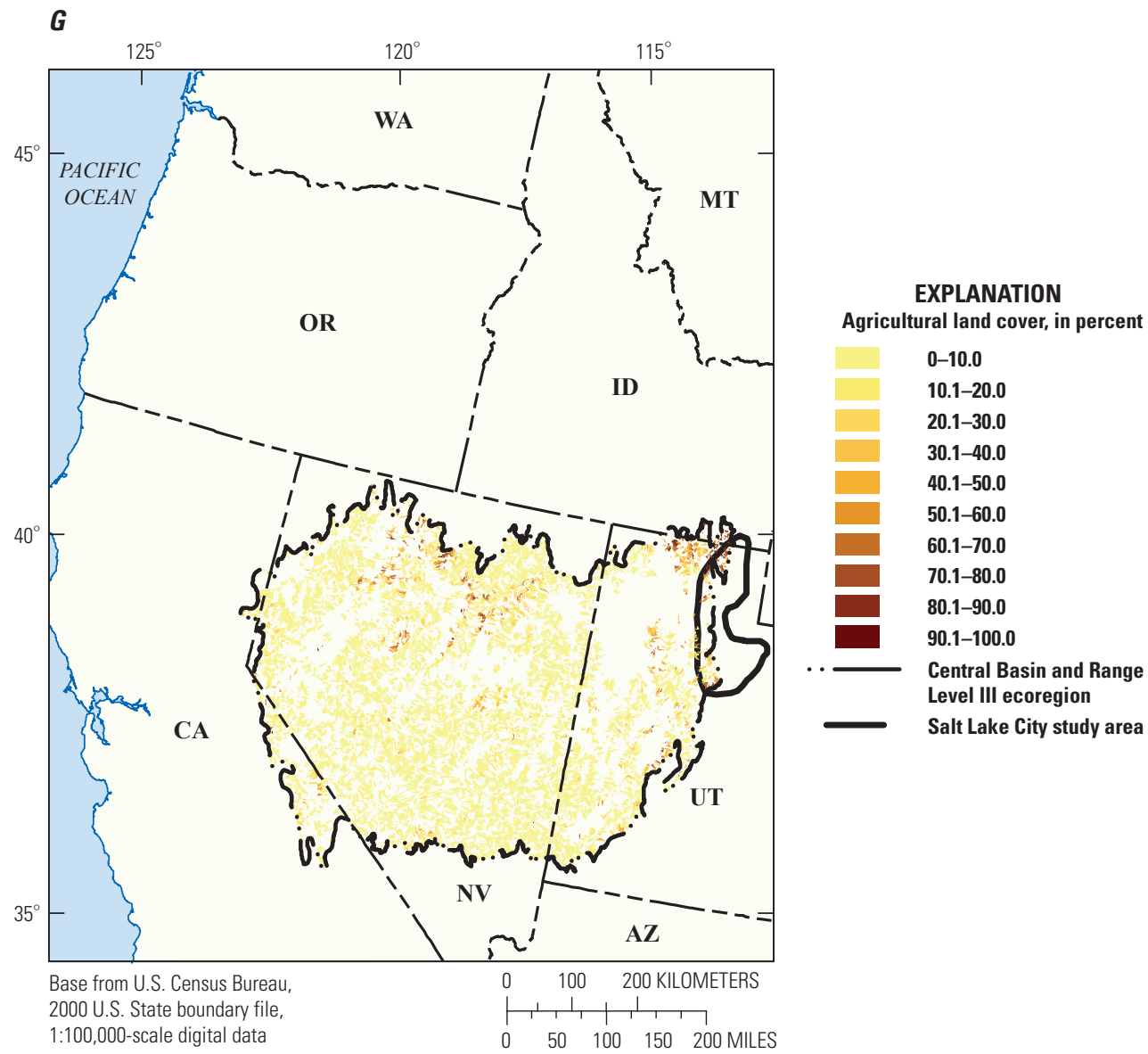

Figure 9. Summary of Central Basin and Range Level III ecoregion watershed characteristics, including $(A)$ average annual temperature, $(B)$ average annual precipitation, $(C)$ elevation, $(D)$ average slope, $(E)$ developed land cover, $(F)$ forested land cover, and $(G)$ agricultural land cover. 

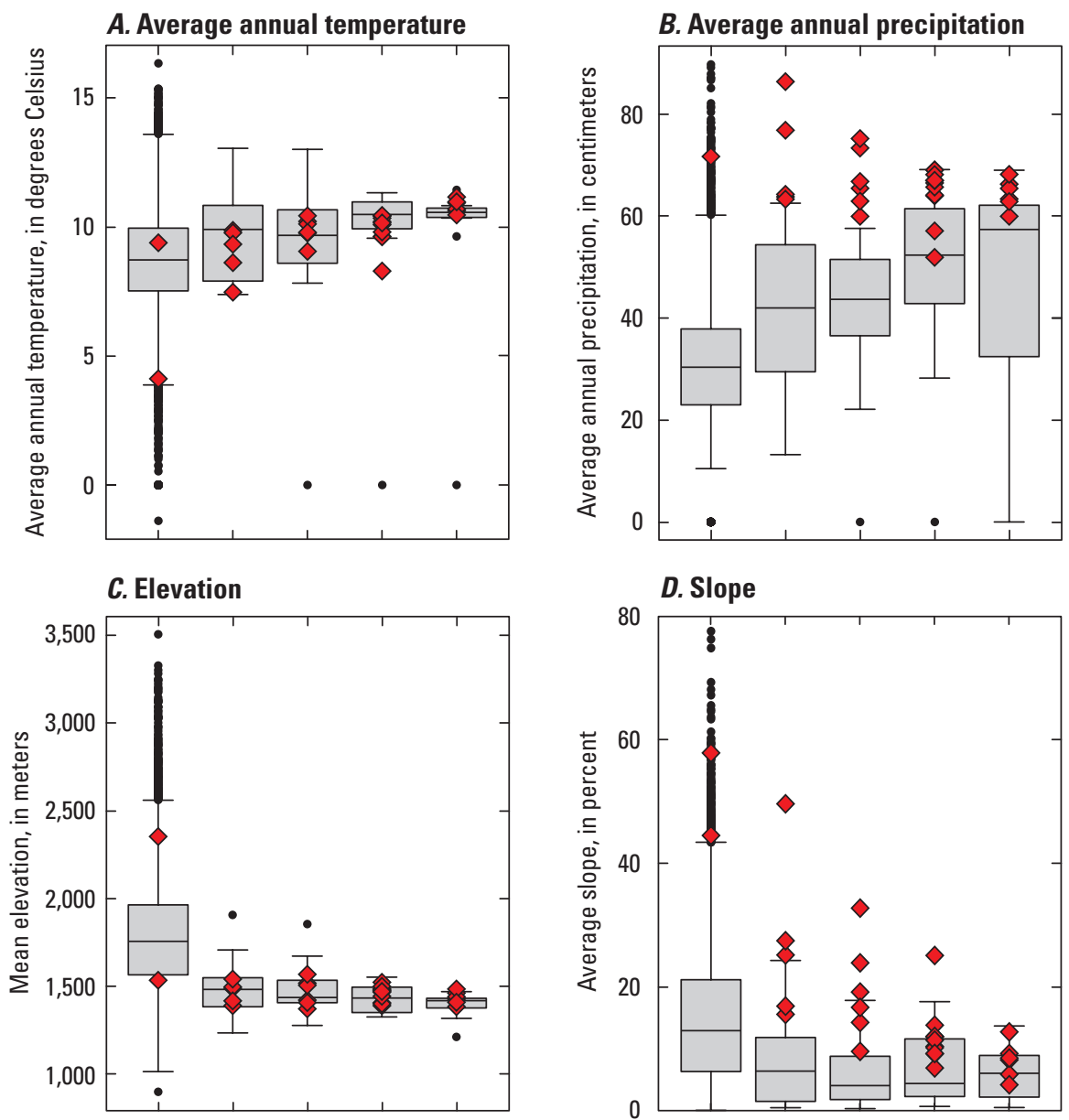

\section{EXPLANATION}

- Outlier

1.5 times the interquartile range

T above the box

$75^{\text {th }}$ percentile $\left.\begin{array}{l}\text { 75th percentile } \\ \text { Median } \\ \text { 25th percentile }\end{array}\right] \begin{aligned} & \text { Interquartile } \\ & \text { range }\end{aligned}$

1.5 times the interquartile range below the box

$\diamond \quad$ EUSE values within development class
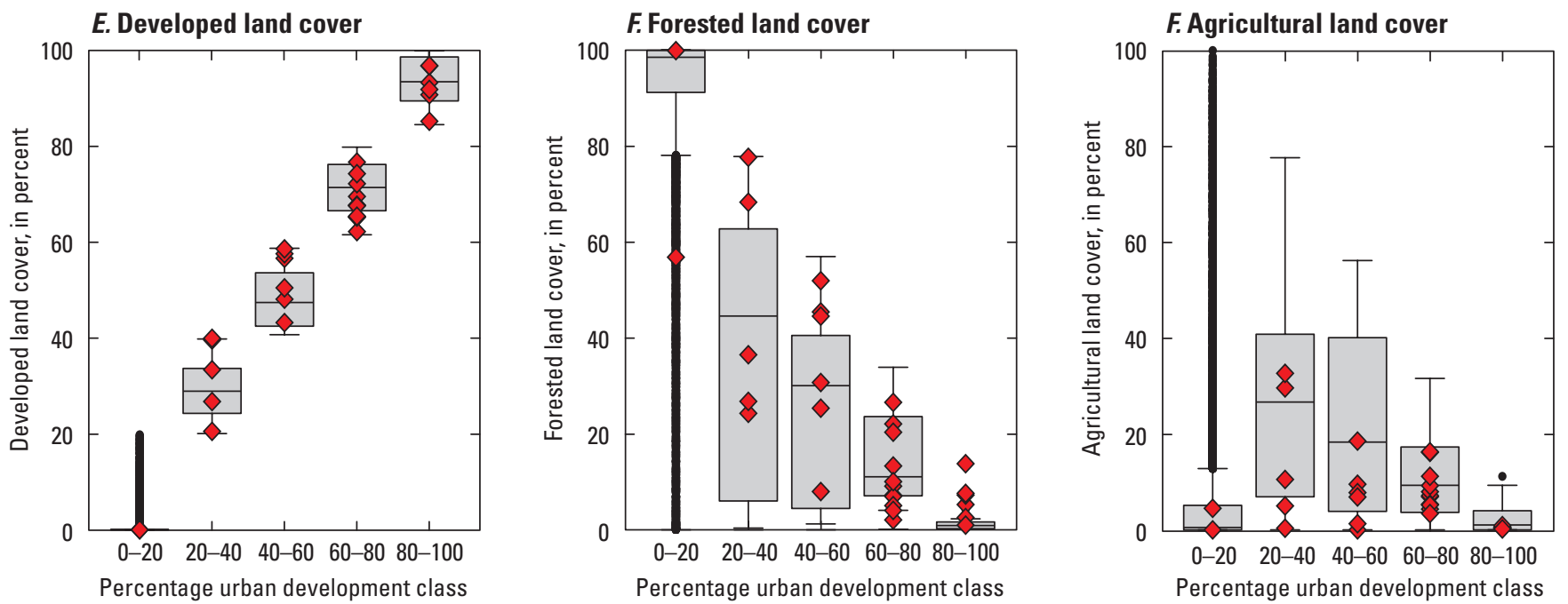

Figure 10. Summary of Central Basin and Range Level III ecoregion and Salt Lake City EUSE study watershed characteristics by percentage of urban development class. $A$, Average annual temperature. $B$, Average annual precipitation. $C$, Mean elevation. $D$, Average slope. E, Developed land cover. $F$, Forested land cover. G, Agricultural land cover. 


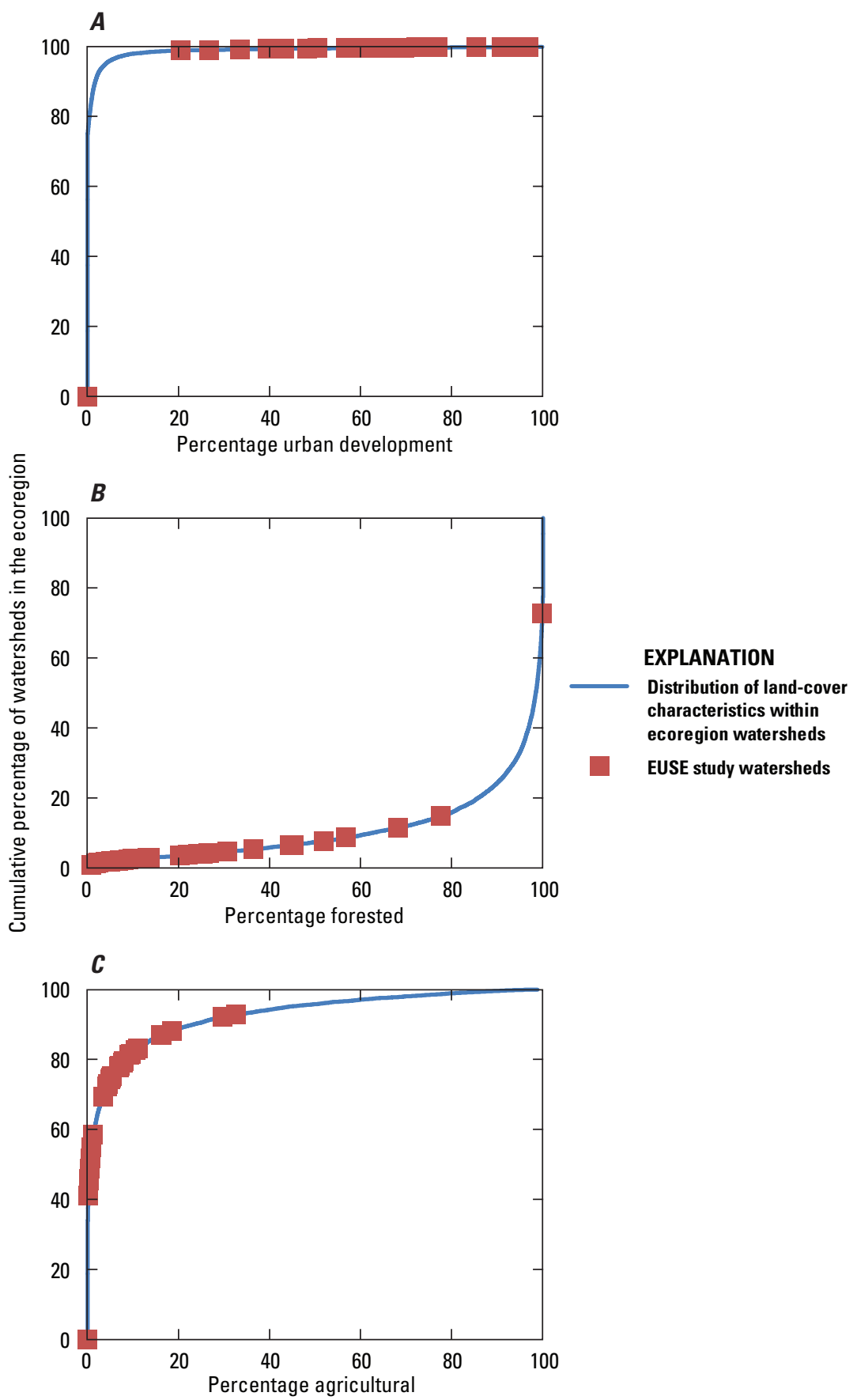

Figure 11. Cumulative distribution plot (blue line) of the percentage of $(A)$ urban development, $(B)$ forested, and $(C)$ agricultural land cover in the Central Basin and Range Level III ecoregion watersheds, and the percentage of the same land-cover types in the Salt Lake City EUSE study watersheds. 


\section{Denver}

The 28 Denver, Colorado, EUSE study watersheds are located in Colorado and southeastern Wyoming, primarily in the High Plains Level III ecoregion, an ecoregion characterized by high elevation, dry climate, and a high percentage of cropland (app. 1). Portions of the watersheds included in the Denver EUSE study area are in adjacent ecoregions, but the entire areas of the watersheds are used in this analysis. The major river basin in the Denver study area is the South Platte River in north-central Colorado and southeastern Wyoming. The climate is semiarid, and precipitation in the study area is affected considerably by topography. Most of the precipitation on the plains results from rainfall, primarily between April and September; however, perennial streamflow also is fed by snowmelt from the mountains. Many smaller streams are ephemeral, and a complex network of ditches and pipes moves water between different areas for domestic water supply, agricultural irrigation, and power generation (Sprague and others, 2006).

The Denver study area includes four main citiesDenver-Aurora, Boulder, and Fort Collins-Loveland, Colorado, and Cheyenne, Wyoming. The combined 2000 population for these four cities, 2.8 million, was a 30 percent increase from 1990 (U.S. Census Bureau, 2009). The economy is diversified and includes telecommunications, software, agriculture, mining, and heavy industry. Denver is a major regional center for U.S. Government offices, a transportation hub, and a tourist gateway to the mountain recreational areas of the southern Rockies (McKnight, 2004).

\section{Climate Variables}

The High Plains Level III ecoregion is an extremely large area that includes portions of eight States extending from South Dakota to Texas. The Denver EUSE study area is located in the northwest portion of the ecoregion. The average annual temperature and precipitation values of the EUSE watersheds have considerably smaller ranges than those of the ecoregion as a whole, but the medians are surprisingly similar given the broad expanse of the ecoregion (tables 3 , 5; figs. $12 A, B ; 13 A, B ; 14 A, B)$. The High Plains ecoregion watersheds, like the Denver EUSE watersheds, have a dry and moderate climate overall. Extremes in temperature occur more often than extremes in precipitation, with a $12^{\circ} \mathrm{C}$ range, which is the second highest among the nine EUSE studies.

\section{Topographic Variables}

The Denver EUSE watersheds are located in the higher elevations of the High Plains Level III ecoregion (tables 3, 5; figs. $12 C, D ; 13 C, D ; 14 C, D)$. The median elevation for the Denver EUSE watersheds, $1,720 \mathrm{~m}$, is much higher than the median value for the High Plains ecoregion watersheds, $1,130 \mathrm{~m}$. The elevation range is much larger for the ecoregion watersheds than for the EUSE watersheds. Median slope values are higher for the Denver EUSE watersheds than for the ecoregion watersheds, which is an indication of the position of the Denver metropolitan area along the slopes of the Rockies.

\section{Land-Cover Variables}

The amount of developed land cover in the High Plains Level III ecoregion is low as indicated by a median value of 2.5 percent developed land and the third quartile value of 3.7 (tables 3, 5; figs. 12E, 13E, 15A). The Denver EUSE watersheds span the entire gradient of urbanization that exists in the High Plains ecoregion but, as in Salt Lake City, include many of the ecoregion's watersheds that have more than 20 percent developed land. The land cover in the High Plains ecoregion is predominantly agricultural, and the undeveloped land cover in the EUSE watersheds is also predominantly agricultural.

The range of forest and shrubland percentages for the Denver EUSE watersheds is much less than for the High Plains ecoregion as a whole (figs. 12E, 15B). A large number of outliers exist on the high end of the distribution for the ecoregion watersheds, and these outliers are not represented in the EUSE watersheds. The range of herbaceous/cultivated land cover in the ecoregion watersheds is well represented by the EUSE watersheds (figs. 12E, 15C). The high median value of 95 percent agricultural land cover and a first quartile development value of 88 percent indicate that the vast majority of land in the ecoregion is for agricultural uses (table 3). 

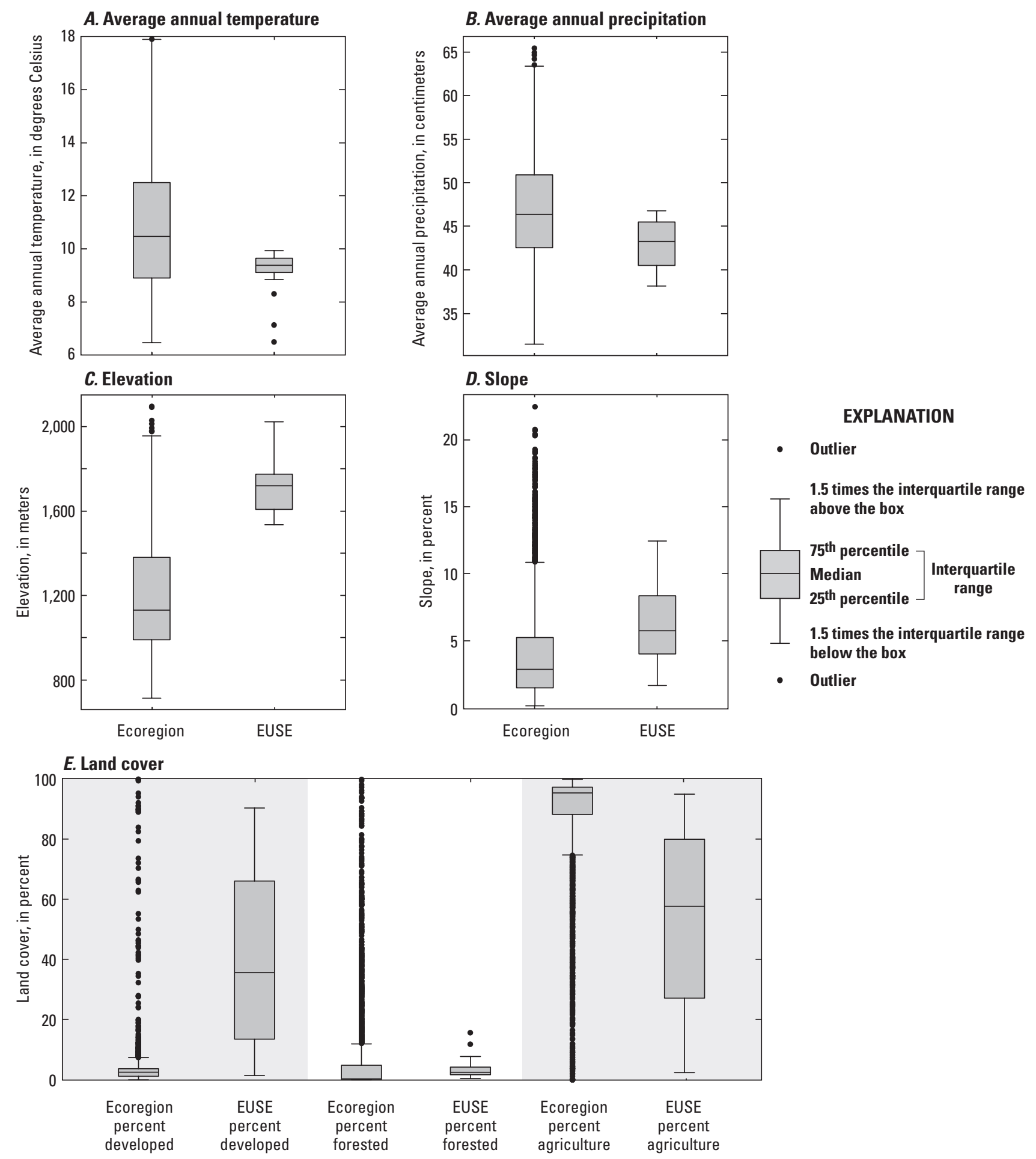

Figure 12. Summary of High Plains Level III ecoregion and Denver EUSE study watershed characteristics, including $(A)$ average annual temperature, $(B)$ average annual precipitation, $(C)$ elevation, $(D)$ percent slope, and $(E)$ percent land cover. 

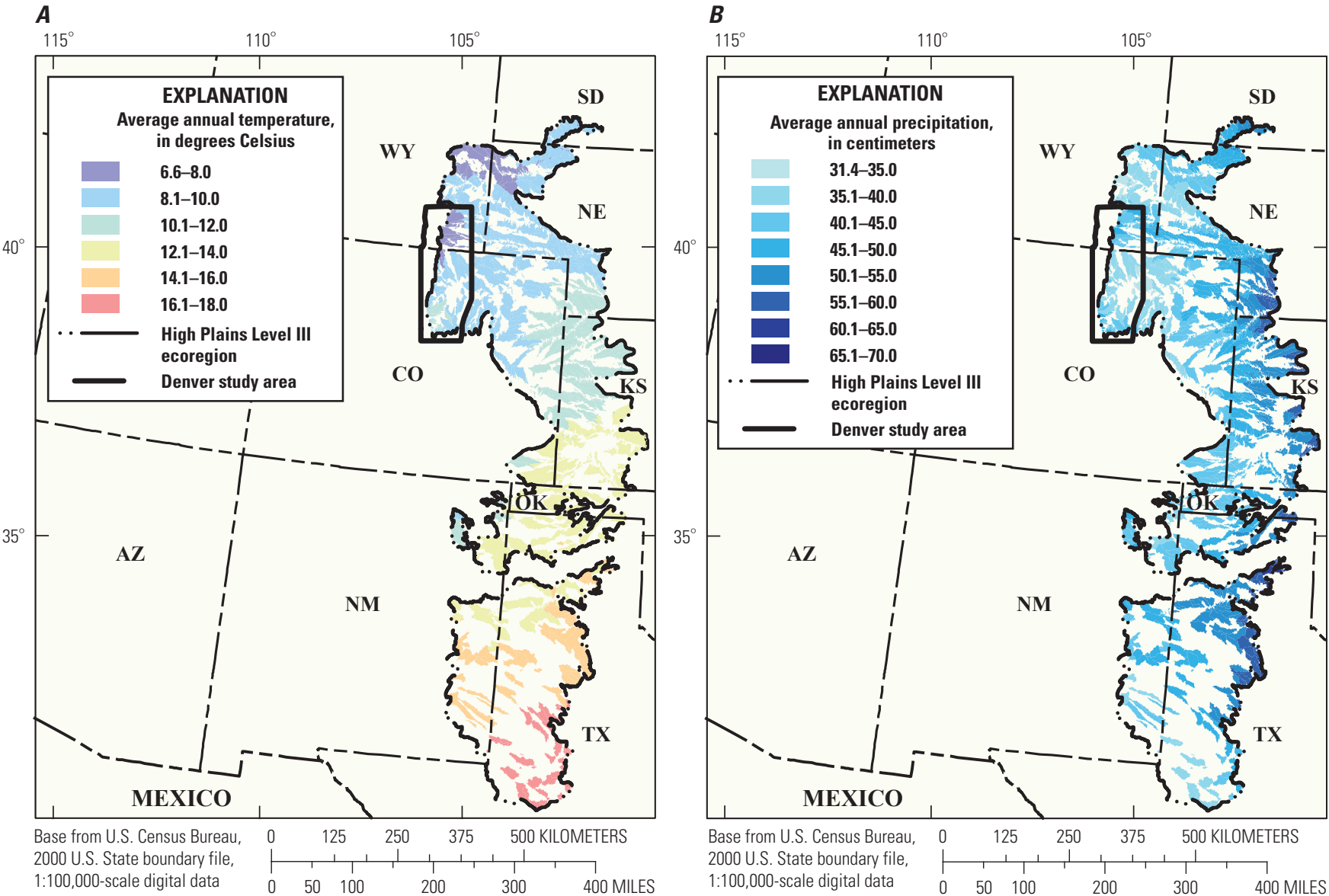

Figure 13. Summary of High Plains Level III ecoregion watershed characteristics, including $(A)$ average annual temperature, $(B)$ average annual precipitation, $(C)$ elevation, $(D)$ average slope, $(E)$ developed land cover, $(F)$ forested land cover, and $(G)$ agricultural land cover. 

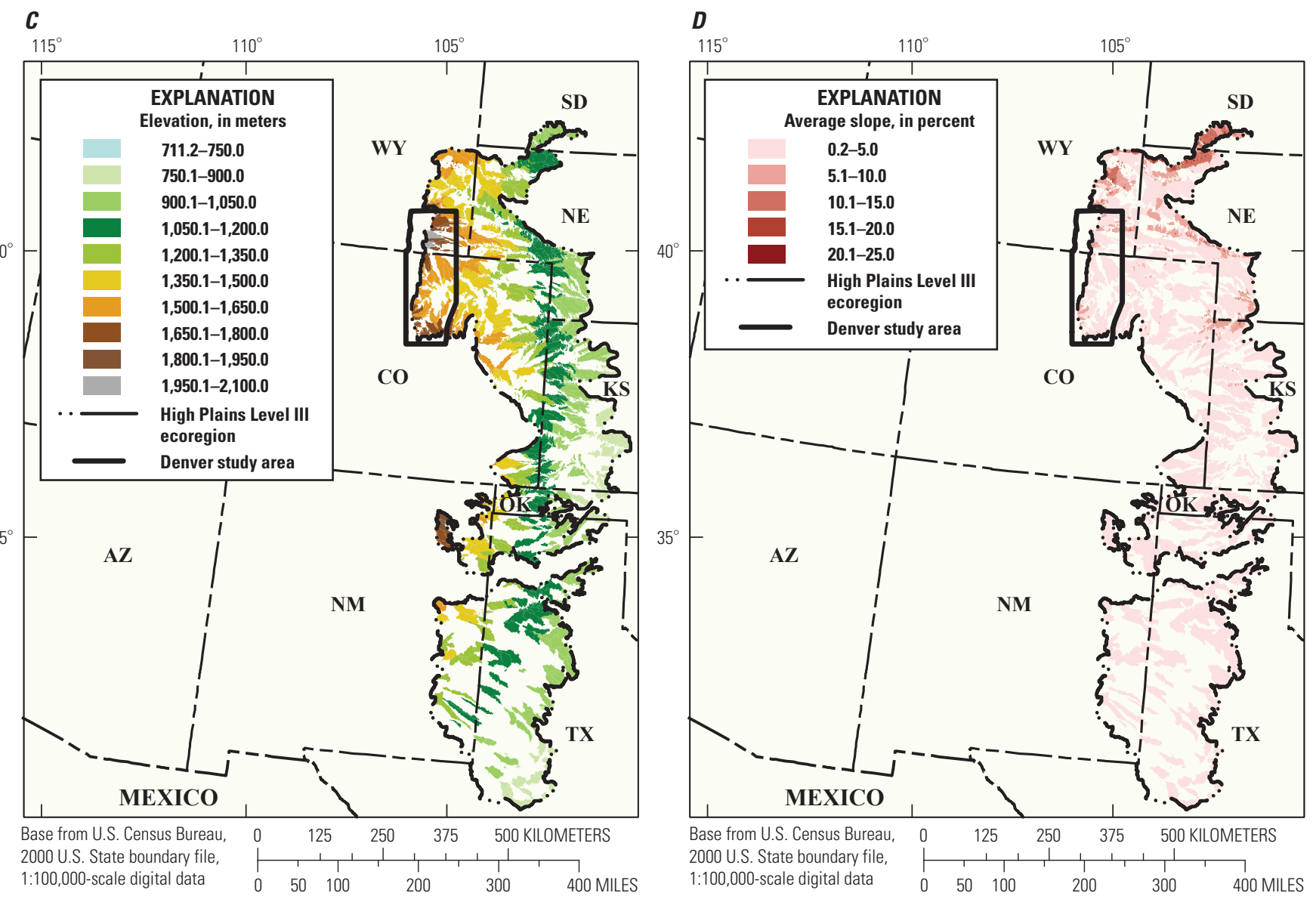

Figure 13-Continued. Summary of High Plains Level III ecoregion watershed characteristics, including $(A)$ average annual temperature, $(B)$ average annual precipitation, $(C)$ elevation, $(D)$ average slope, $(E)$ developed land cover, $(F)$ forested land cover, and $(G)$ agricultural land cover. 

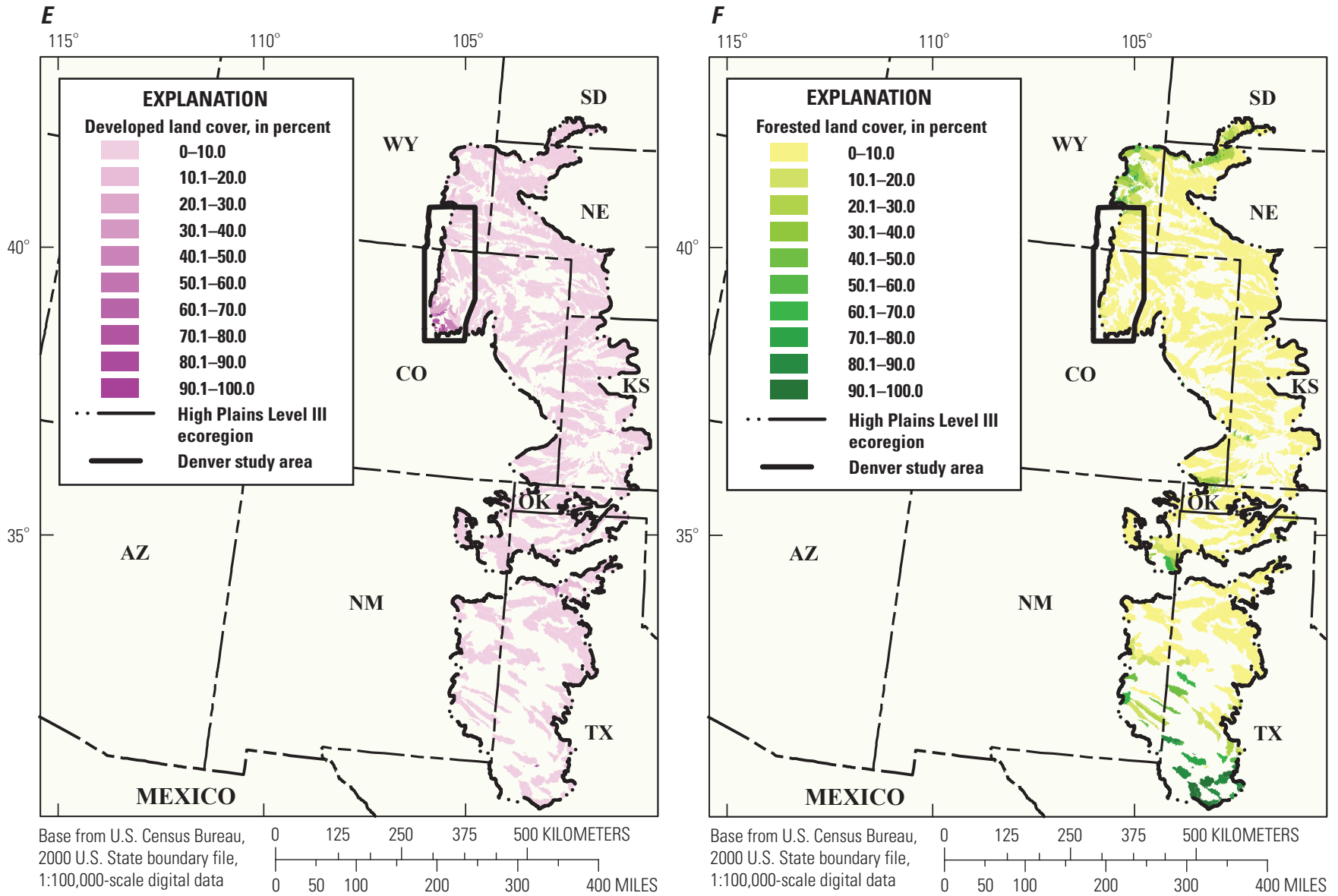

Figure 13-Continued. Summary of High Plains Level III ecoregion watershed characteristics, including $(A)$ average annual temperature, $(B)$ average annual precipitation, $(C)$ elevation, $(D)$ average slope, $(E)$ developed land cover, $(F)$ forested land cover, and $(G)$ agricultural land cover. 


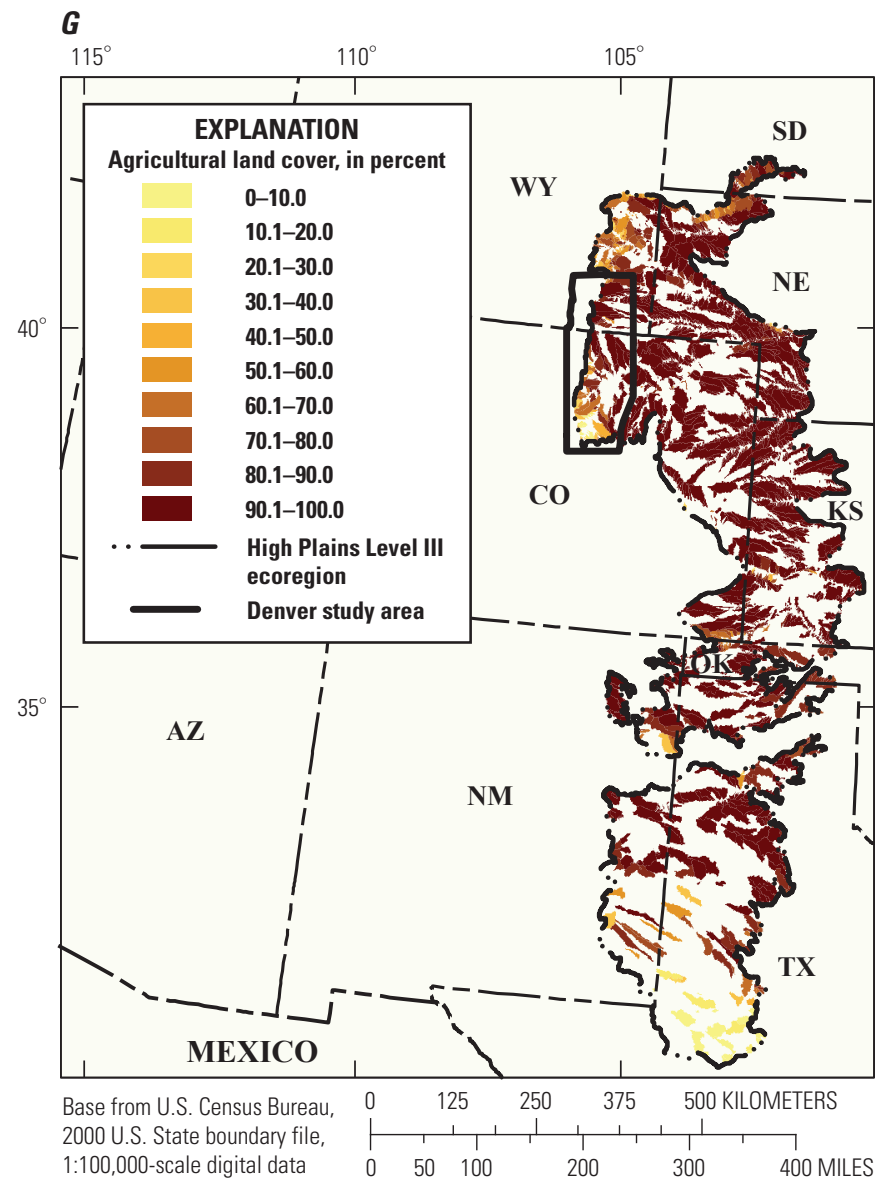

Figure 13-Continued. Summary of High Plains Level III ecoregion watershed characteristics, including $(A)$ average annual temperature, $(B)$ average annual precipitation, $(C)$ elevation, $(D)$ average slope, $(E)$ developed land cover, $(F)$ forested land cover, and $(G)$ agricultural land cover. 

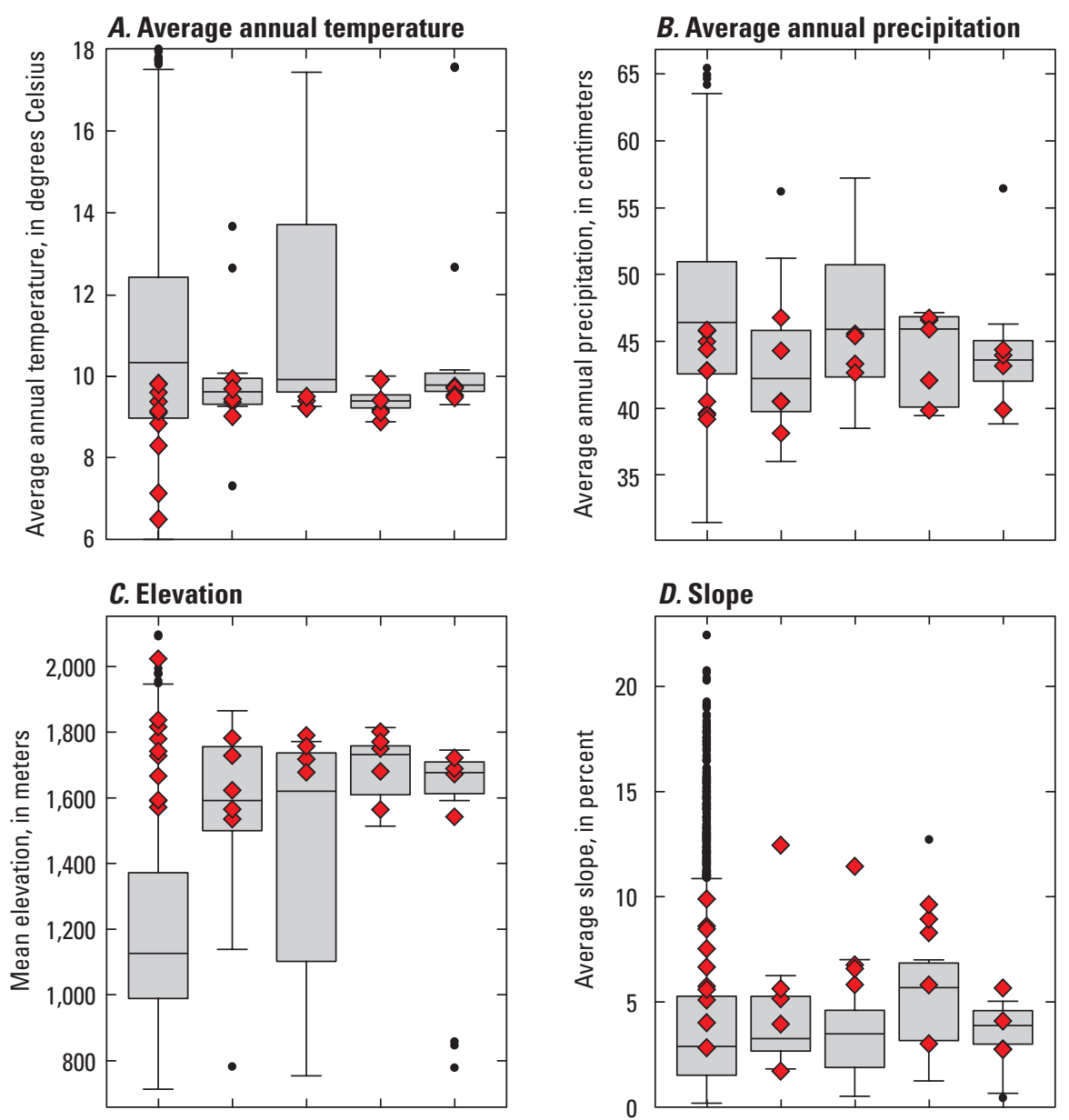

\section{EXPLANATION}

- Outlier

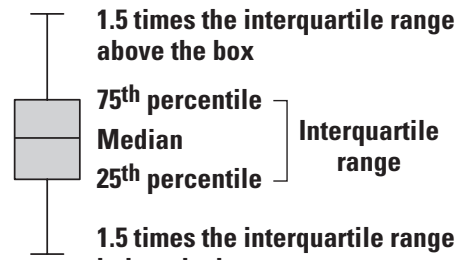
below the box

$\diamond \quad$ EUSE values within development class
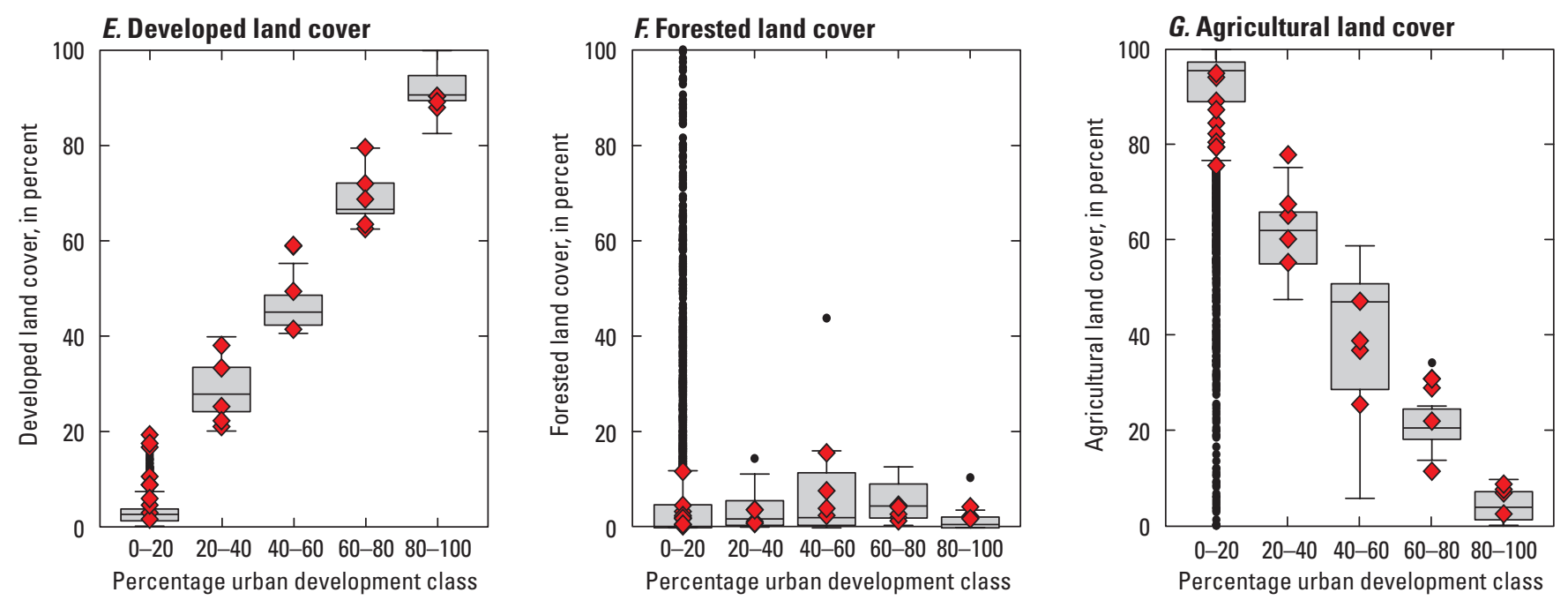

Figure 14. Summary of High Plains Level III ecoregion and Denver EUSE study watershed characteristics by percentage of urban development class. $A$, Average annual temperature. $B$, Average annual precipitation. $C$, Mean elevation. $D$, Average slope. $E$, Developed land cover. F, Forested land cover. G, Agricultural land cover. 


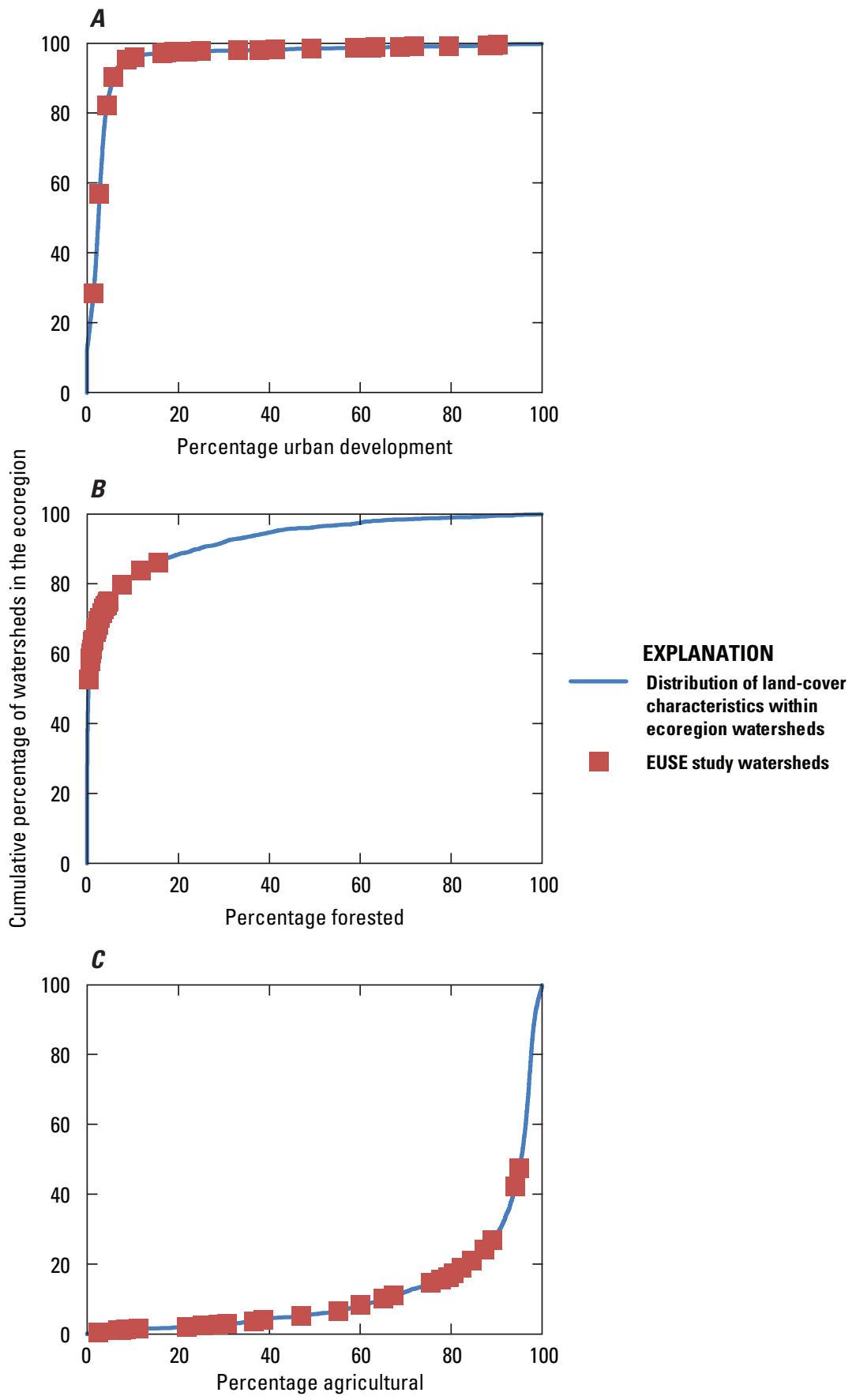

Figure 15. Cumulative distribution plot (blue line) of the percentage of $(A)$ urban development, $(B)$ forested, and $(C)$ agricultural land cover in the High Plains Level III ecoregion watersheds, and the percentage of the same land-cover types in the Denver EUSE study watersheds. 


\section{Dallas}

The 29 Dallas, Texas, EUSE study watersheds are within the Texas Blackland Prairie Level III ecoregion (app. 1). The soil texture is primarily fine to moderately fine (Giddings and others, 2009). The climate is warm and semiarid, with precipitation occurring primarily in the spring and late summer. Surface water in the study area consists primarily of reservoirs, intrawatershed transfers, diversions of water to municipalities, and wastewater effluent. Small streams in the area are generally intermittent. The land is commonly used for pasture, but increasingly land is being used for cropland and urban and industrial uses.

The Dallas EUSE study area includes the metropolitan areas of Dallas, Fort Worth, and Arlington, with a combined population in 2000 of 5 million, a 29.4 percent increase since 1990 (U.S. Census Bureau, 2009). Dallas is a major regional center, and the economy includes finance, oil, transportation, aerospace, and electronics. Fort Worth, a twin city to Dallas, has an economy based on cattle, railways, and agricultural processing (McKnight, 2004).

\section{Climate Variables}

The range and median values for average annual temperature in the Texas Blackland Prairie ecoregion watersheds are slightly larger than for the Dallas EUSE watersheds, but the difference is small in absolute terms because there is little variation in temperature within the ecoregion (tables 3 , 5; figs. $16 A, B ; 17 A, B ; 18 A, B)$. The range of precipitation values is larger in the ecoregion watersheds, but the median precipitation value is higher for the EUSE watersheds. The precipitation within the EUSE and ecoregion watersheds is not significantly different. Development within the ecoregion is distributed throughout all temperature ranges, and only the least developed watersheds have an average annual precipitation amount greater than $110 \mathrm{~cm}$.

\section{Topographic Variables}

The Texas Blackland Prairie is an area of low relief, which is evident in the elevation and slope values for both the Texas Blackland Prairie Level III ecoregion and the Dallas EUSE watersheds. The interquartile range of elevation values for the EUSE watersheds is similar to that for the ecoregion as a whole, as is the median value (fig. 16C). The interquartile range of slope values and median values for the Dallas EUSE watersheds are similar to the ecoregion watersheds (fig. 16D). The K-W test shows that the EUSE and ecoregion watersheds for these topographic variables are not significantly different.

\section{Land-Cover Variables}

The most striking characteristic of the Texas Black Prairie ecoregion and Dallas EUSE watershed distributions for developed land is the area in the middle of the ecoregion distribution, where no EUSE watersheds are located (figs. $16 E$, $18 E, 19 A)$. The Dallas EUSE study area was defined by the intersection of the Trinity River Basin and the Blackland Prairie ecoregion; within this area watersheds between 25 and 60 percent developed land cover that were suitable for the EUSE sampling were not available. The interquartile range of developed land found in the ecoregion is well represented by the EUSE watersheds. The distribution of the forested and agricultural land-cover classes in the ecoregion are represented by the EUSE watersheds, with the exception of the upper range of the forested land cover and the middle range of the agricultural land cover (fig. 19B, C). The land cover in the Blackland Prairie ecoregion is predominantly agricultural, and the undeveloped land in the EUSE watersheds is also predominantly agricultural. Results of the K-W test indicate that the developed, forest, and agricultural characteristics in the EUSE and ecoregion watersheds are not from statistically different populations. 

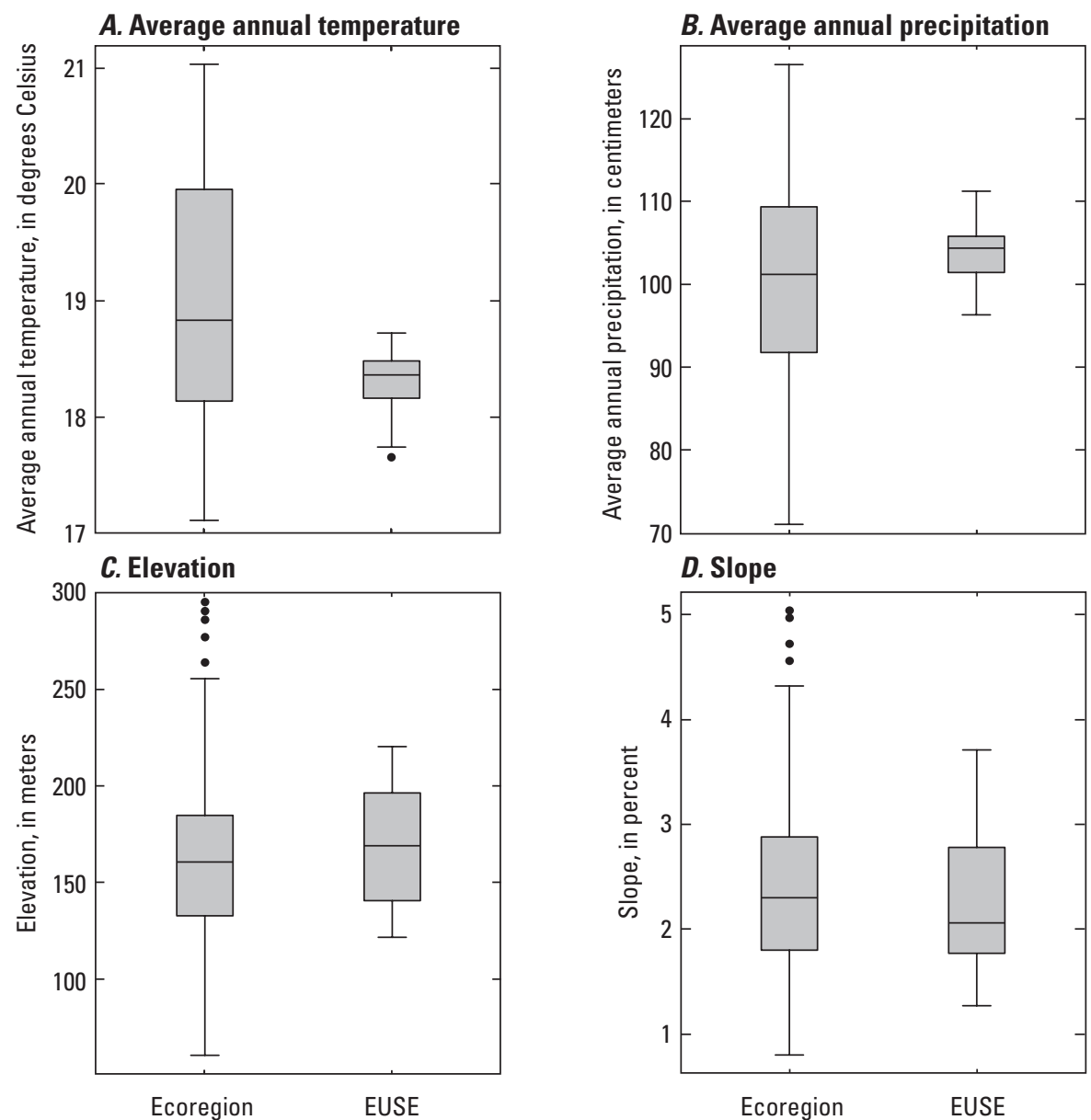

\section{EXPLANATION}

- Outlier

1.5 times the interquartile range above the box $\left.\begin{array}{l}75^{\text {th }} \text { percentile } \\ \text { Median }\end{array}\right]$ Interquartile $25^{\text {th }}$ percentile $\quad$ range

Ecoregion EUSE

Ecoregion

EUSE

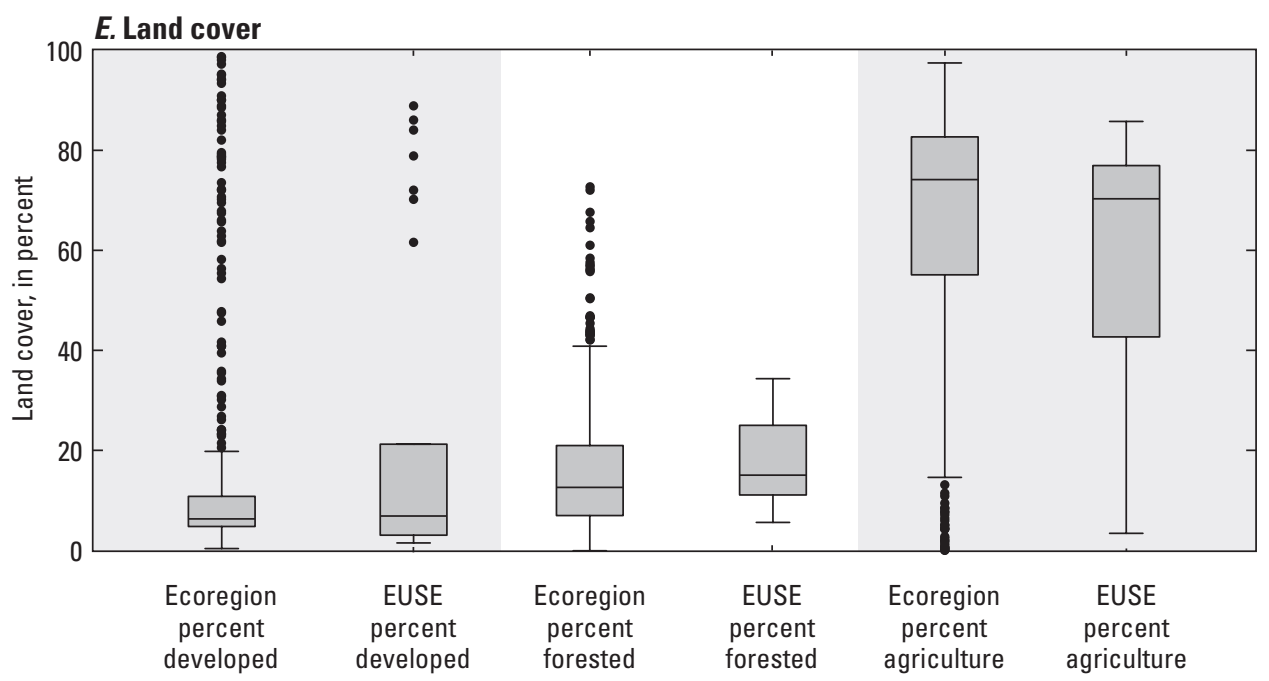

Figure 16. Summary of Texas Blackland Prairie Level III ecoregion and Dallas EUSE study watershed characteristics, including $(A)$ average annual temperature, $(B)$ average annual precipitation, $(C)$ elevation, $(D)$ percent slope, and $(E)$ percent land cover. 

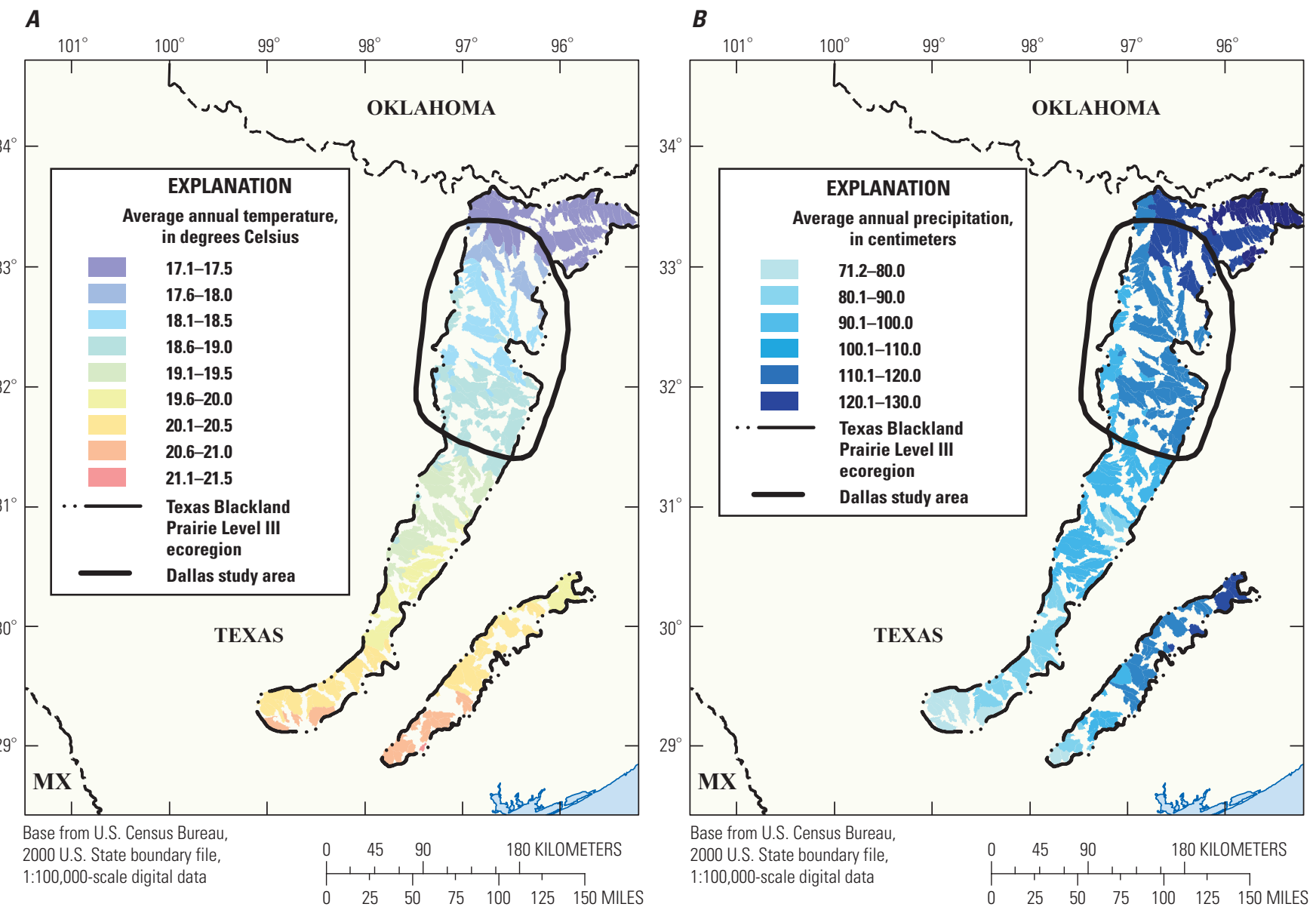

Figure 17. Summary of Texas Blackland Prairie Level III ecoregion watershed characteristics, including $(A)$ average annual temperature, $(B)$ average annual precipitation, $(C)$ elevation, $(D)$ average slope, $(E)$ developed land cover, $(F)$ forested land cover, and $(G)$ agricultural land cover. 
C

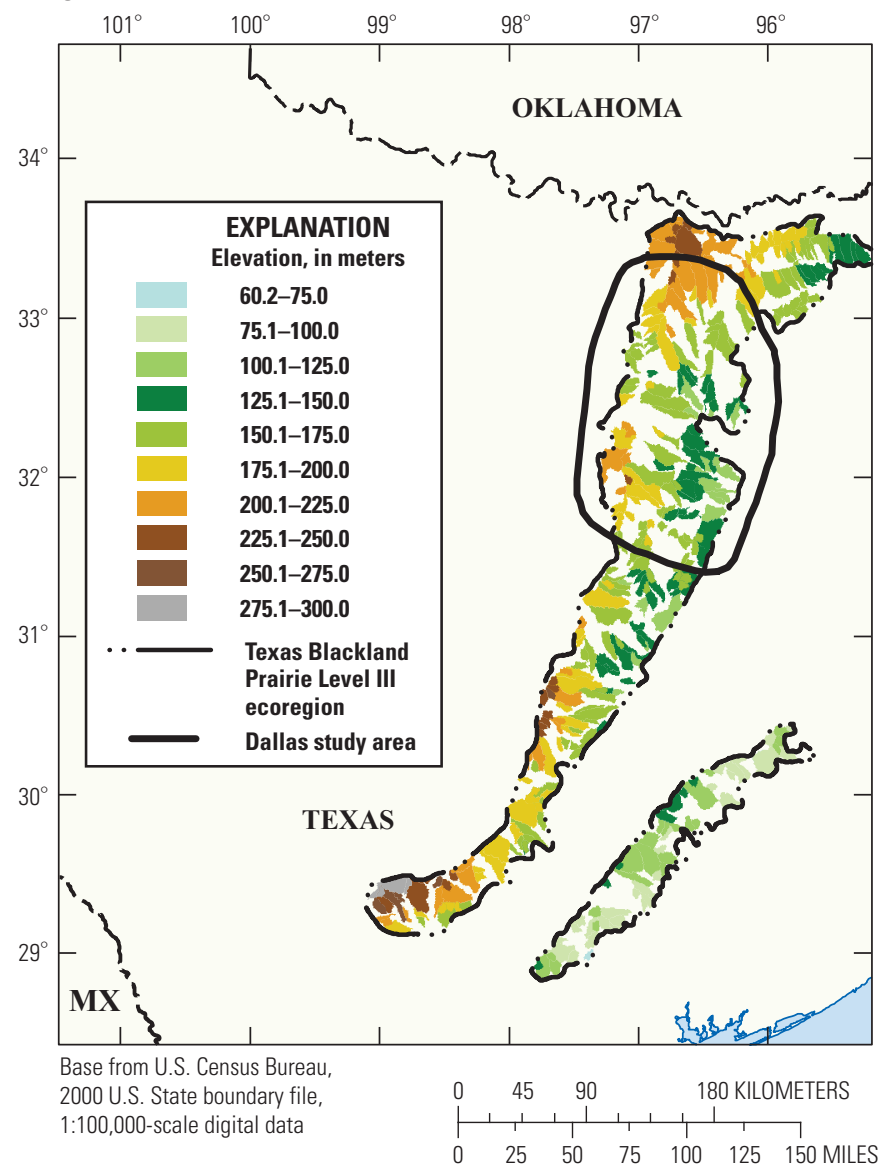

D

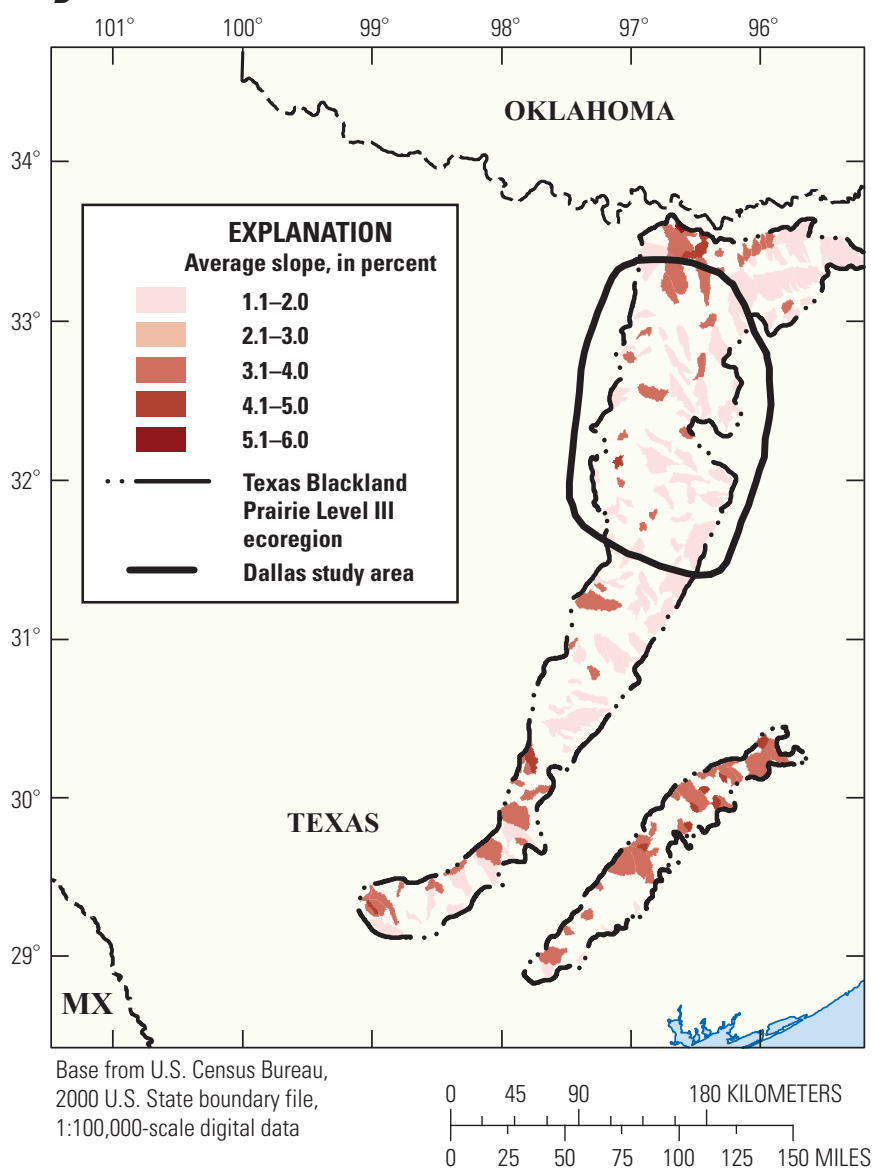

Figure 17-Continued. Summary of Texas Blackland Prairie Level III ecoregion watershed characteristics, including $(A)$ average annual temperature, $(B)$ average annual precipitation, $(C)$ elevation, $(D)$ average slope, $(E)$ developed land cover, $(F)$ forested land cover, and $(G)$ agricultural land cover. 

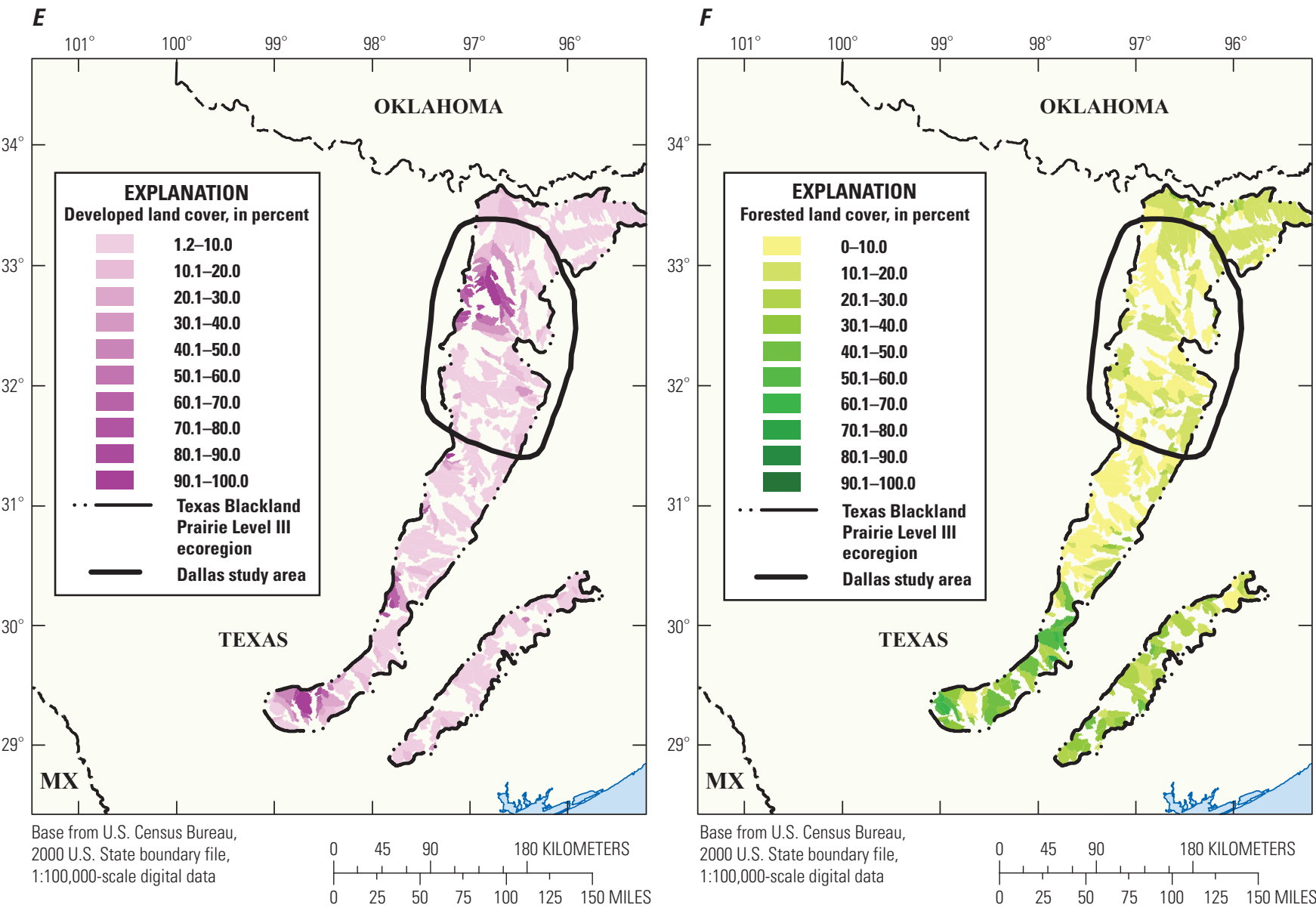

Figure 17-Continued. Summary of Texas Blackland Prairie Level III ecoregion watershed characteristics, including $(A)$ average annual temperature, $(B)$ average annual precipitation, $(C)$ elevation, $(D)$ average slope, $(E)$ developed land cover, $(F)$ forested land cover, and $(G)$ agricultural land cover. 


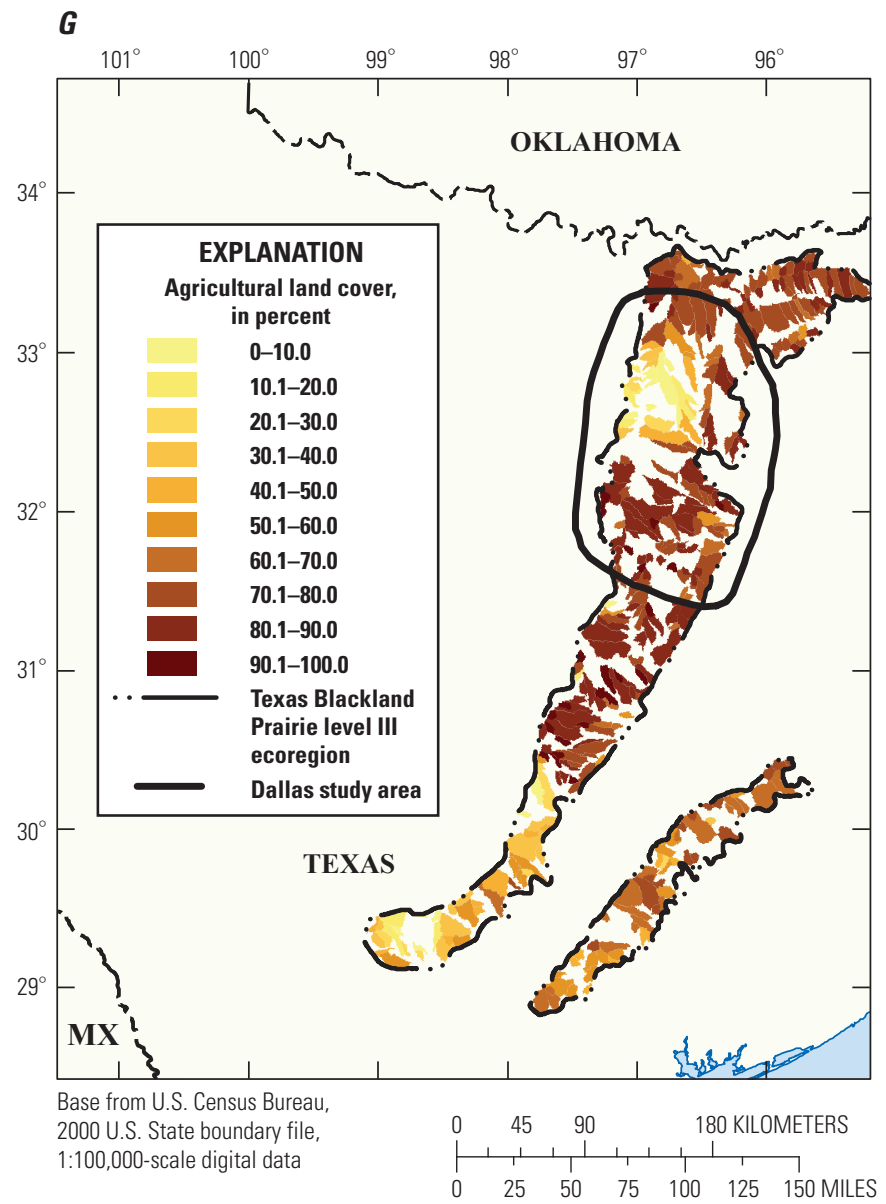

Figure 17-Continued. Summary of Texas Blackland Prairie Level III ecoregion watershed characteristics, including $(A)$ average annual temperature, $(B)$ average annual precipitation, $(C)$ elevation, $(D$ average slope, $(E)$ developed land cover, $(F)$ forested land cover, and $(G)$ agricultural land cover. 

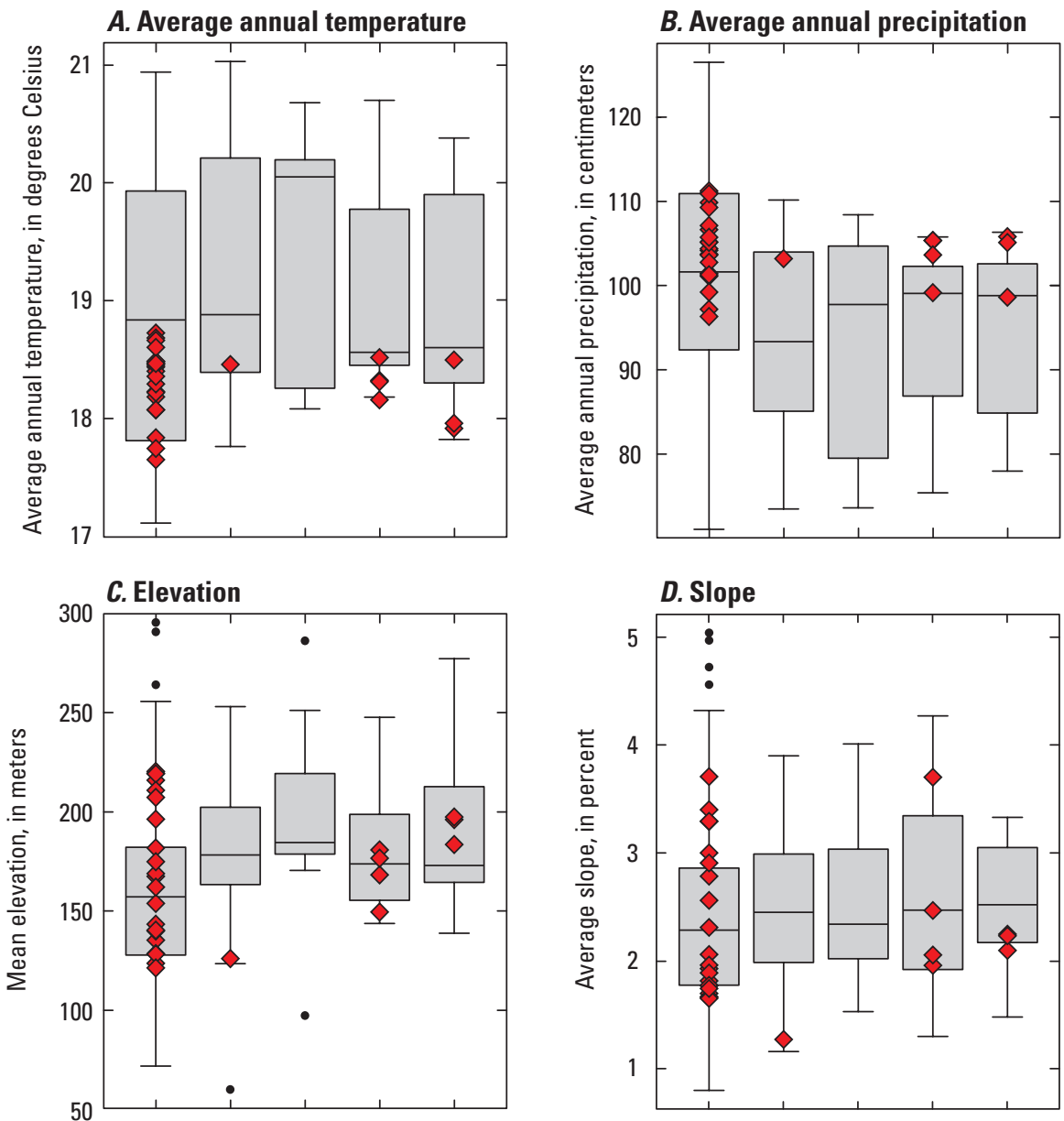

\section{EXPLANATION}

- Outlier

\begin{tabular}{|l}
\multicolumn{1}{c}{$\left.\begin{array}{l}1.5 \text { times the interquartile range } \\
\text { above the box } \\
75^{\text {th }} \text { percentile } \\
\text { Median } \\
25^{\text {th }} \text { percentile }\end{array}\right] \begin{array}{c}\text { Interquartile } \\
\text { range }\end{array}$} \\
1.5 times the interquartile range
\end{tabular} below the box

$\diamond \quad$ EUSE values within development class
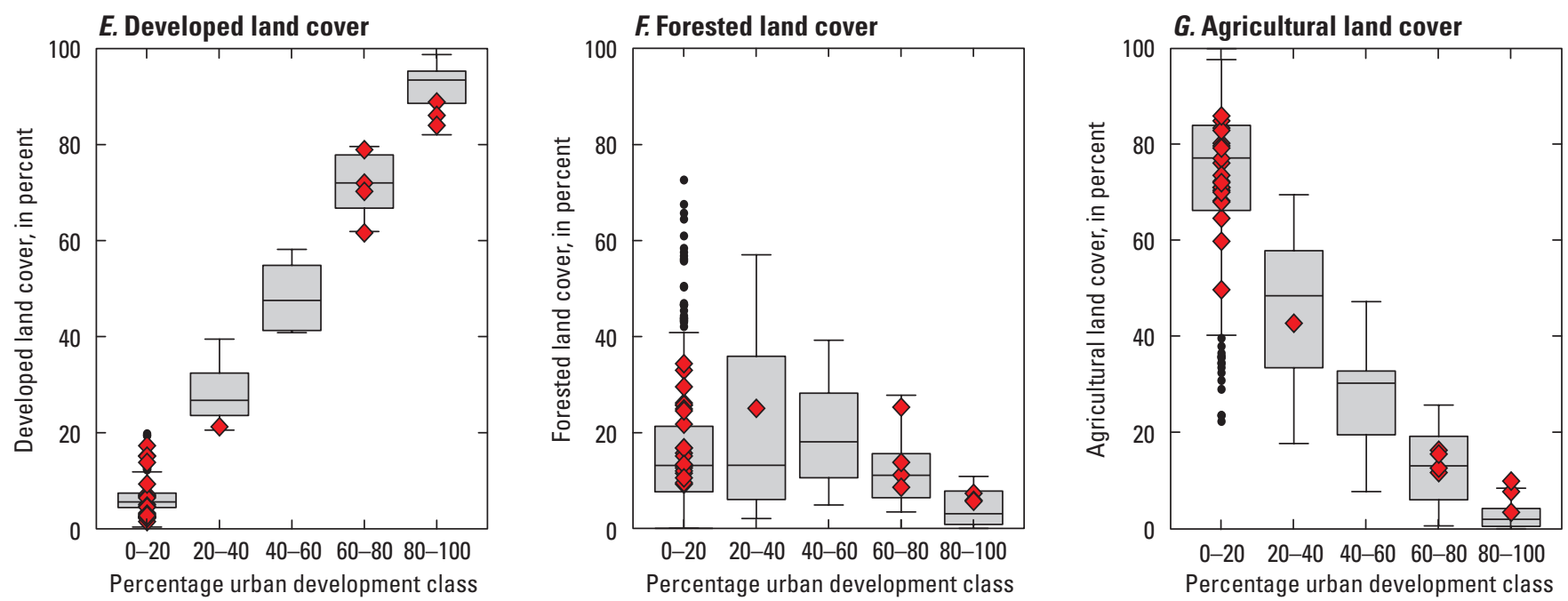

Figure 18. Summary of Blackland Prairie Level III ecoregion and Dallas EUSE study watershed characteristics by percentage of urban development class. $A$, Average annual temperature. $B$, Average annual precipitation. $C$, Mean elevation. $D$, Average slope. $E$, Developed land cover. F, Forested land cover. G, Agricultural land cover. 

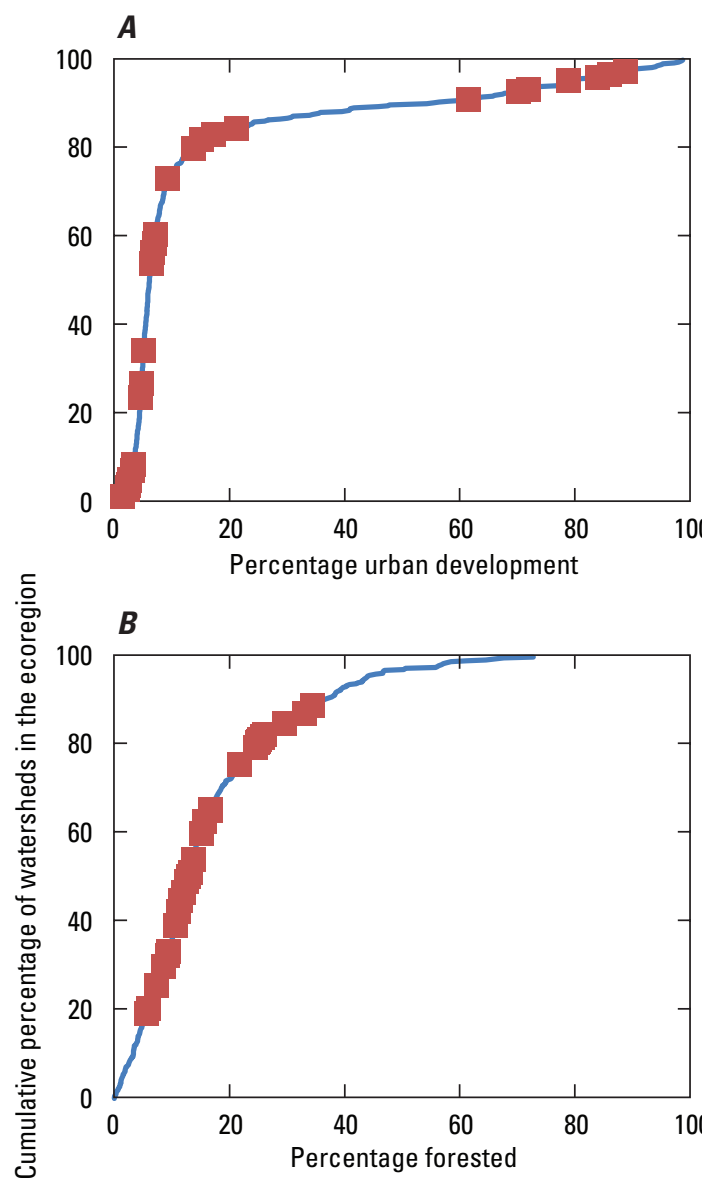

EXPLANATION

Distribution of land-cover characteristics within ecoregion watersheds EUSE study watersheds

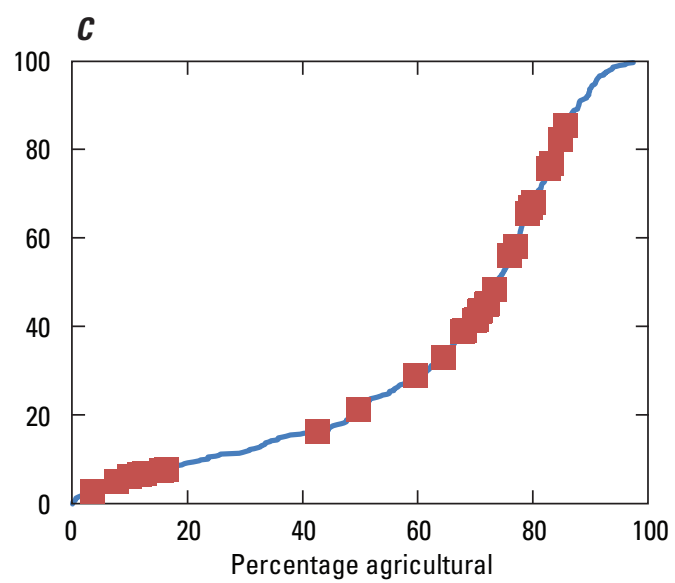

Figure 19. Cumulative distribution plot (blue line) of the percentage of $(A)$ urban development, $(B)$ forested, and $(C)$ agricultural land cover in the Texas Blackland Prairie Level III ecoregion watersheds, and the percentage of the same landcover types in the Dallas EUSE study watersheds. 


\section{Milwaukee}

The 30 Milwaukee, Wisconsin, EUSE study watersheds are located primarily in the Southeastern Wisconsin Till Plains Level III ecoregion (app. 1). Outside of the industrial and commercial centers of Milwaukee and Green Bay, the ecoregion is predominantly agricultural, with low topographic relief and a mosaic of forest types, crop types, and soils. The land surface is characterized by glacial outwash plains, lacustrine watersheds, level to rolling till plains, and extensive wetland areas. The climate is characterized by cold winters and moderate, wet summers, with most of the precipitation occurring between May and September. Highest streamflows usually occur in March through May as a result of snowmelt or a combination of rain and snow; however, summer thunderstorms can produce flood peaks that exceed snowmelt peaks (Richards and others, 2010). The pre-development land cover was a mixture of hardwood forests (north), oak savannas (west), and tall-grass prairies (south).

The Milwaukee metropolitan study area includes five main population centers-Milwaukee-Waukesha-West Allis, Green Bay, Appleton, Racine, and Oshkosh-Neenah. The combined 2000 population for these five areas, 2.3 million, was an 8 percent increase from 1990 (U.S. Census Bureau, 2009). Because of their shipping ports, Milwaukee and Green Bay are the largest industrial, manufacturing, and commercial centers in the study area. Dairy and livestock farming and associated corn and soybean production represent the dominant land use in the region (Peters, 1997).

\section{Climate Variables}

The Southeastern Wisconsin Till Plains ecoregion has the second smallest area of the EUSE study areas and has a relatively homogeneous climate. The temperatures range from $7^{\circ} \mathrm{C}$ to $9^{\circ} \mathrm{C}$ for both the Milwaukee EUSE watersheds and the Southeastern Wisconsin Till Plains ecoregion watersheds (table 3; figs. 20A, $B ; 21 A, B ; 22 A, B$ ). The range of average annual precipitation is also similar between the two areas although the EUSE watersheds have a lower median value and all EUSE watershed values are below the $3^{\text {rd }}$ quartile of the ecoregion watersheds. The K-W test indicates that there is no difference between EUSE and ecoregion watersheds in terms of average annual temperature variable.

\section{Topographic Variables}

The range and median elevations for the Milwaukee EUSE watersheds are smaller than those of the Southeastern Wisconsin Till Plains ecoregion watersheds (figs. 20C, D; $22 C, D$ ). Median percentage slopes are also similar between the two areas, although the ecoregion watersheds have a wider range of values, and the ecoregion watersheds values for elevation or slope greater than the $75^{\text {th }}$ percentile are not represented in the EUSE watersheds. All levels of development for the ecoregion have a wide range of elevation and slope with the exception of the highest developed quintile; climate in the highest level of development for the ecoregion is similar to that of the EUSE watersheds.

\section{Land-Cover Variables}

The range of developed land values for the Milwaukee EUSE watersheds includes the range of values for the Southeastern Wisconsin Till Plains ecoregion as a whole (figs. 20E, 22E, 23A). The ecoregion watersheds have a lower median and $75^{\text {th }}$ percentile of developed land than the EUSE watersheds, indicating that there are relatively few watersheds in the ecoregion watersheds with large amounts of developed land. The range and median of forest/shrubland percentages are similar for the ecoregion and EUSE watersheds (figs. 20E, $23 B$ ). The land cover in the Southeastern Wisconsin Till Plains ecoregion is predominantly agricultural, and the undeveloped land in the Milwaukee EUSE watersheds is also predominantly agricultural (figs. 22G, 23C). Of the land-cover variables, only the ecoregion and EUSE watershed values for forested and agricultural land cover were drawn from the same population. 

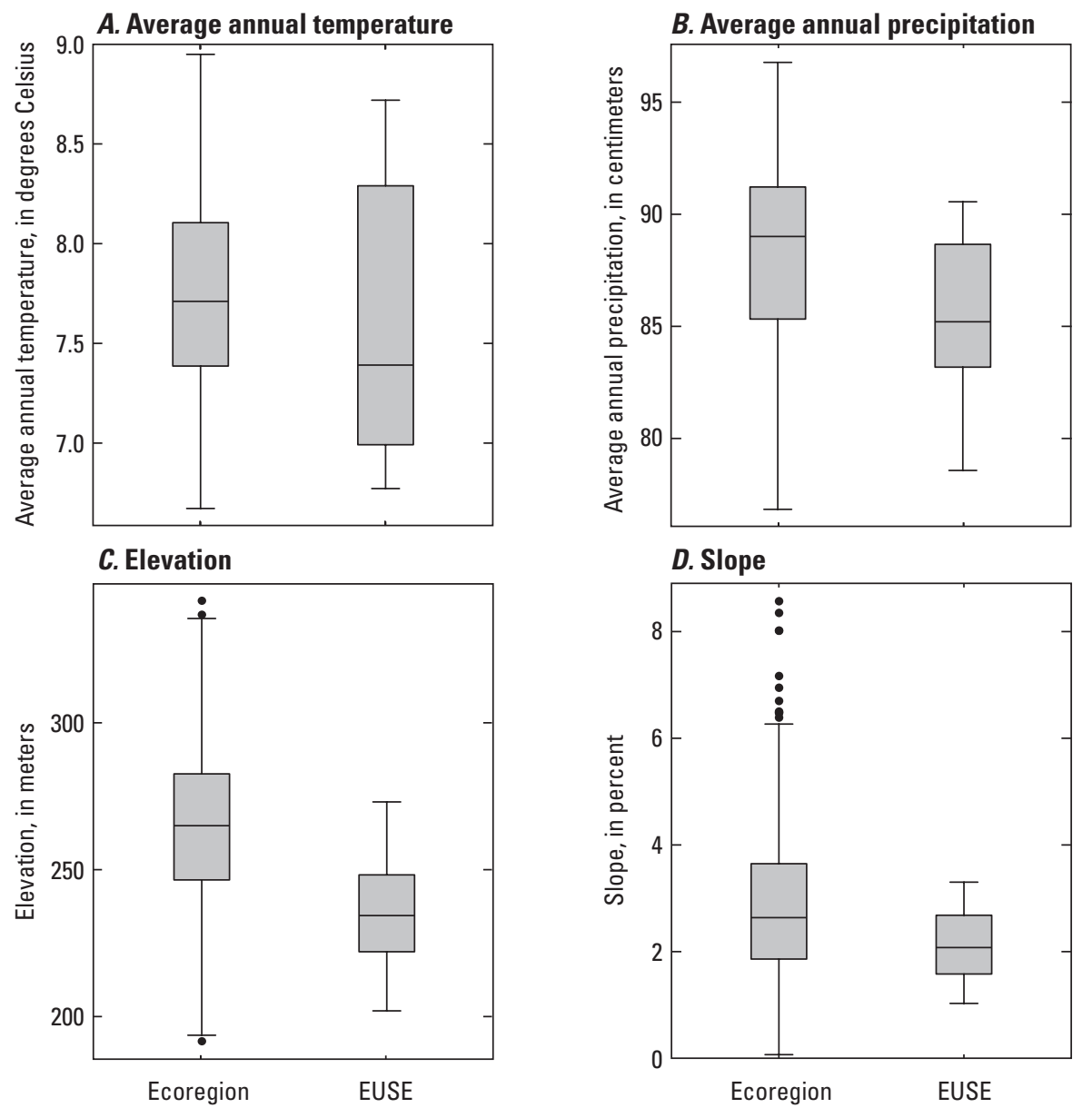

\section{EXPLANATION}

- Outlier

1.5 times the interquartile range above the box

75th percentile Median Interquartile $25^{\text {th }}$ percentile $ـ$ range

.5 times the interquartile range below the box

- Outlier

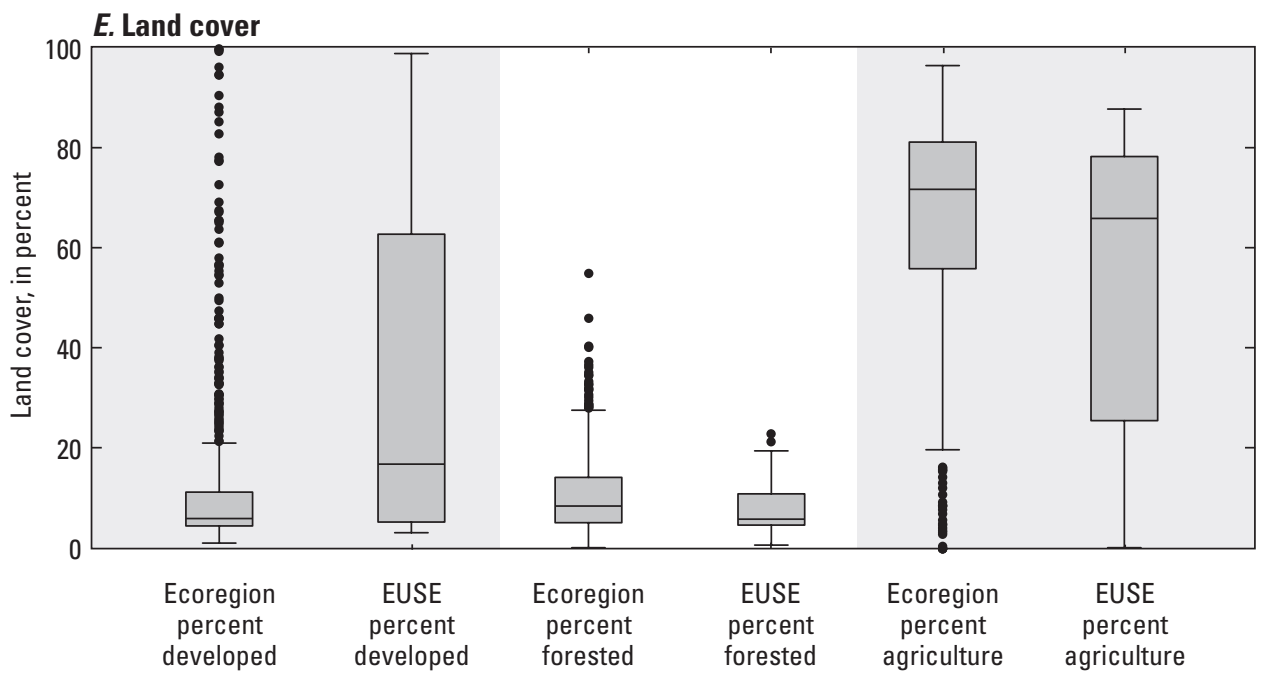

Figure 20. Summary of Southeastern Wisconsin Till Plains Level III ecoregion and Milwaukee EUSE study watershed characteristics, including $(A)$ average annual temperature, $(B)$ average annual precipitation, $(C)$ elevation, $(D)$ percent slope, and $(E)$ percent land cover. 
$\boldsymbol{A}$

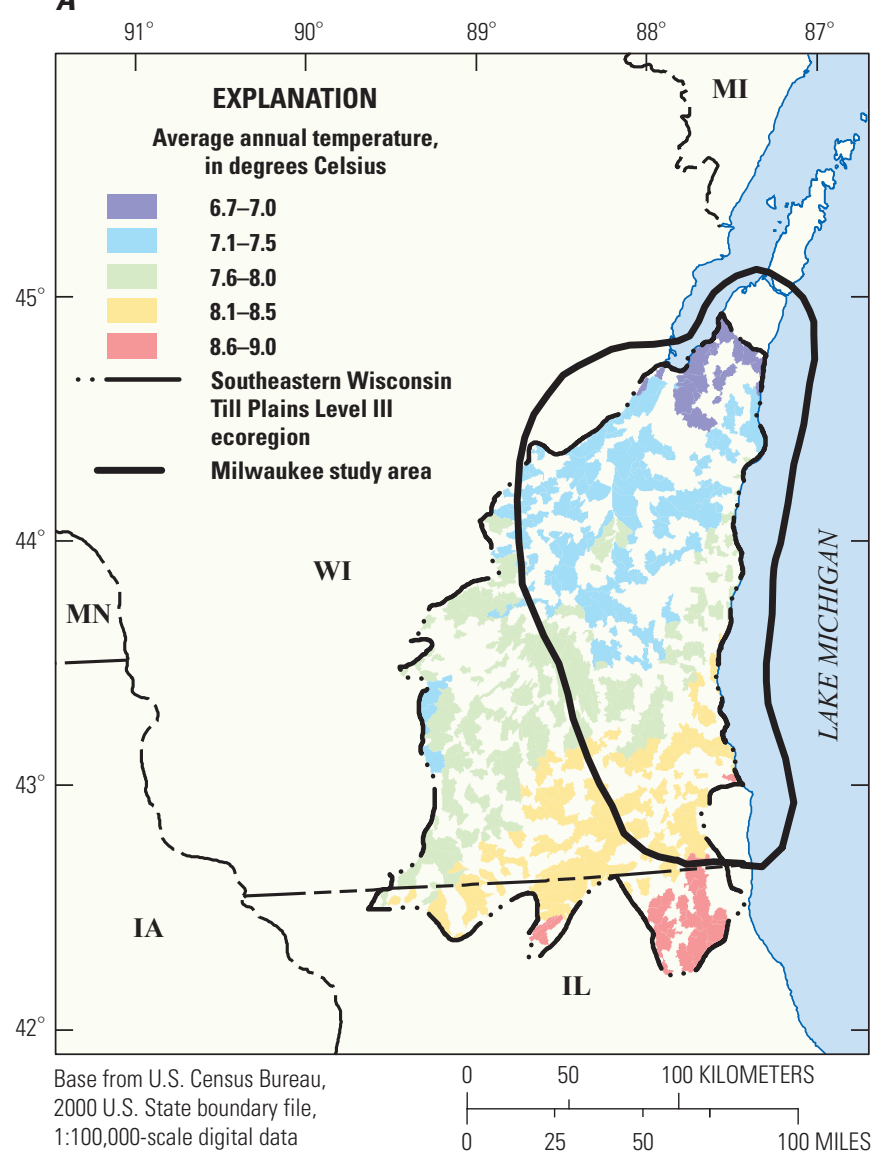

$\boldsymbol{B}$

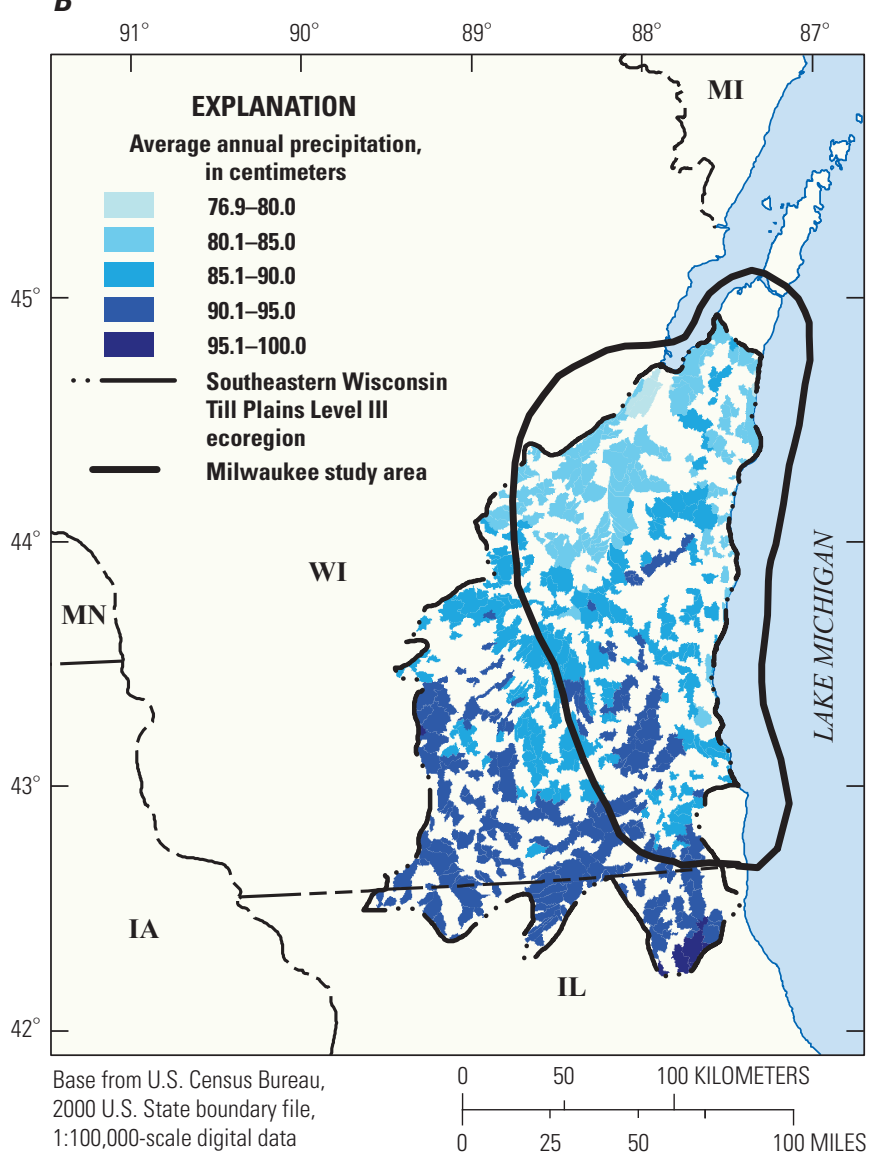

Figure 21. Summary of Southeastern Wisconsin Till Plains Level III ecoregion watershed characteristics, including $(A)$ average annual temperature, $(B)$ average annual precipitation, $(C)$ elevation, $(D)$ average slope, $(E)$ developed land cover, $(F)$ forested land cover, and $(G)$ agricultural land cover. 
C

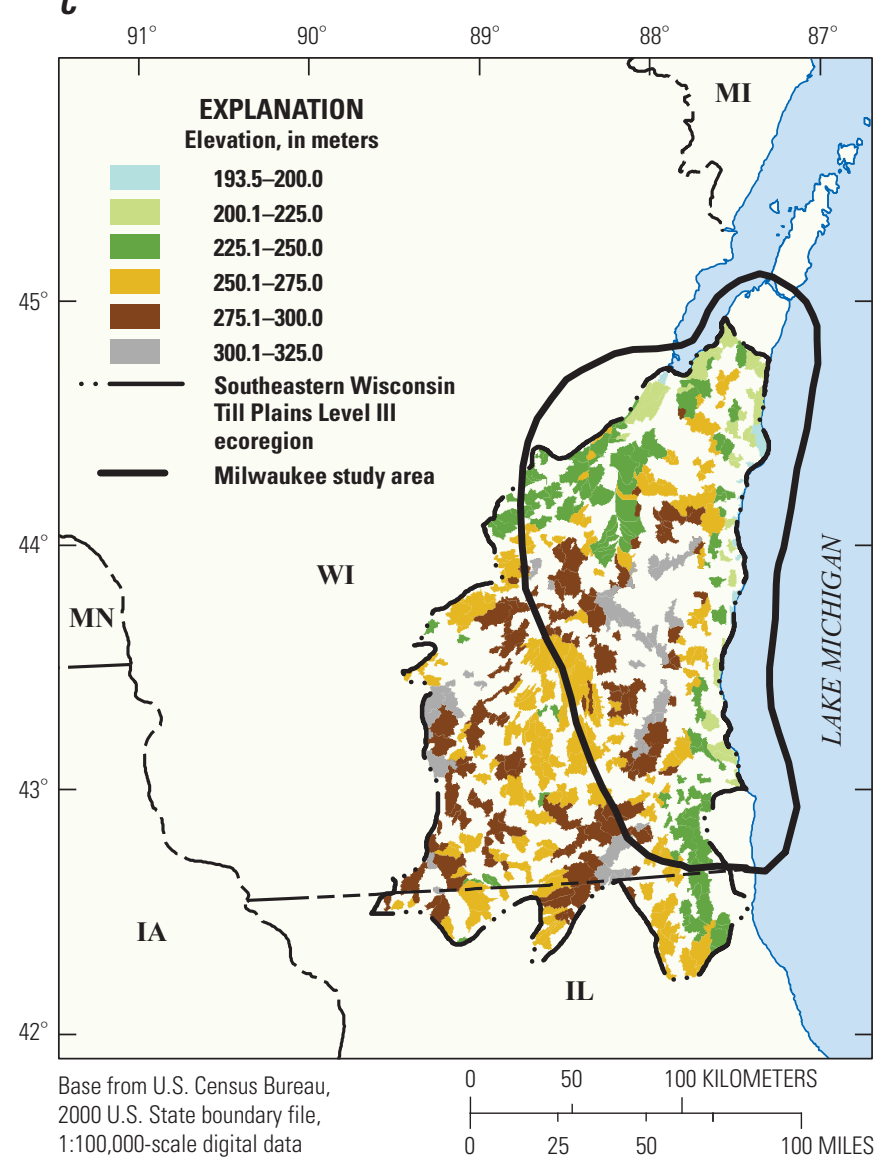

D

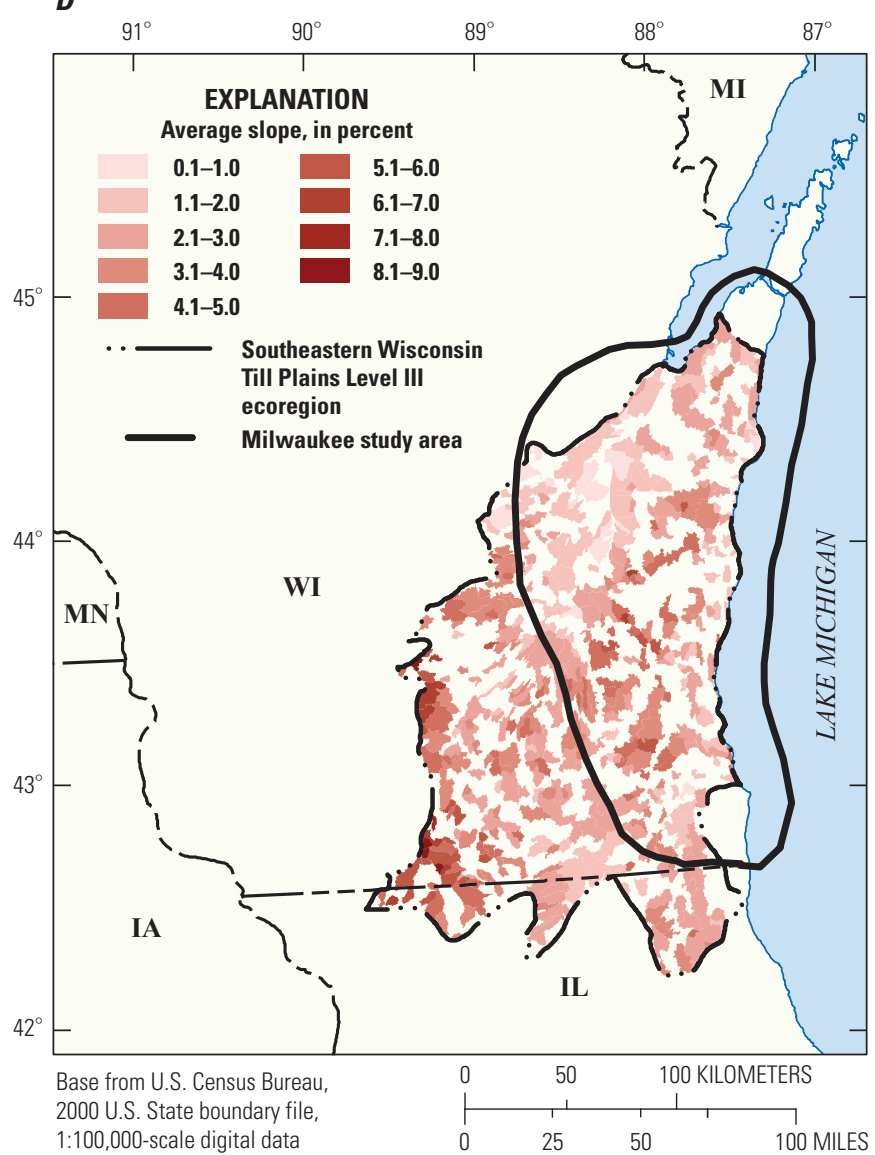

Figure 21-Continued. Summary of Southeastern Wisconsin Till Plains Level III ecoregion watershed characteristics, including $(A)$ average annual temperature, $(B)$ average annual precipitation, $(C)$ elevation, $(D)$ average slope, $(E)$ developed land cover, $(F)$ forested land cover, and $(G)$ agricultural land cover. 
$\boldsymbol{E}$

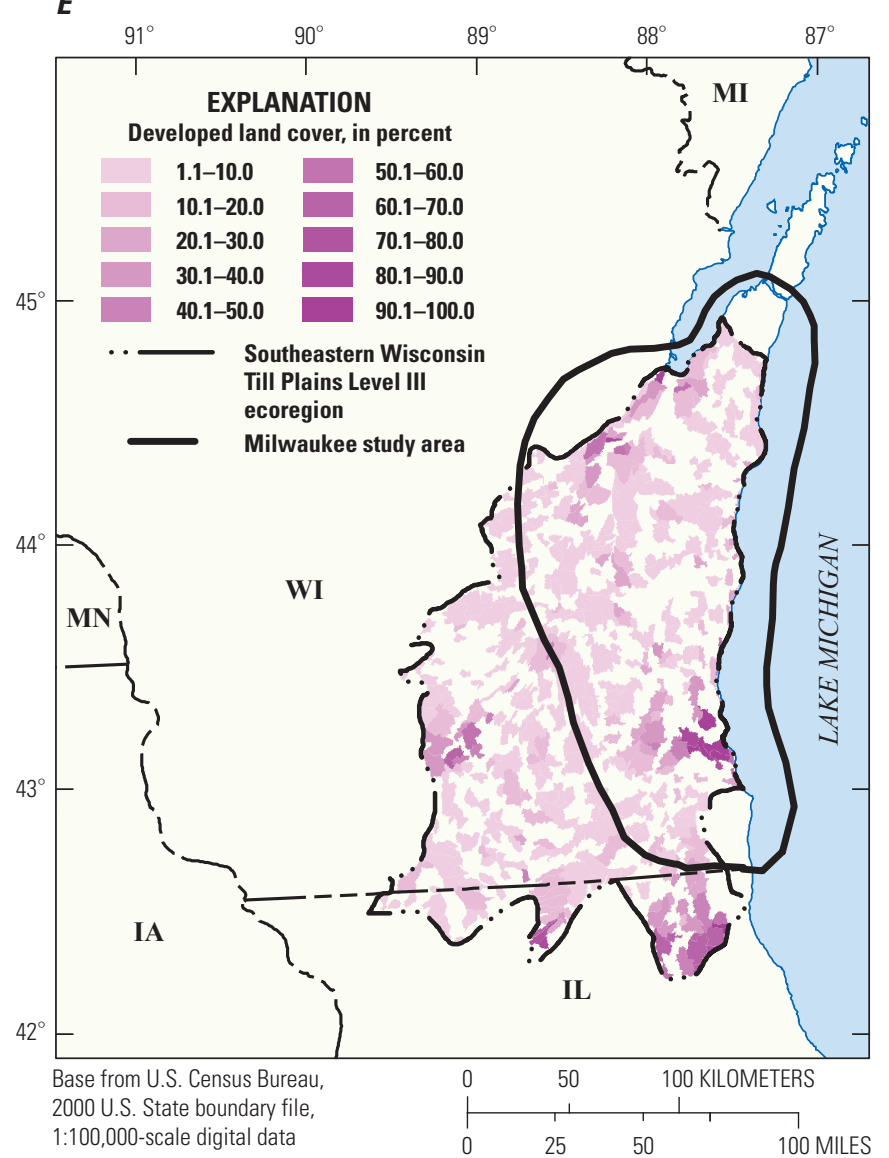

F

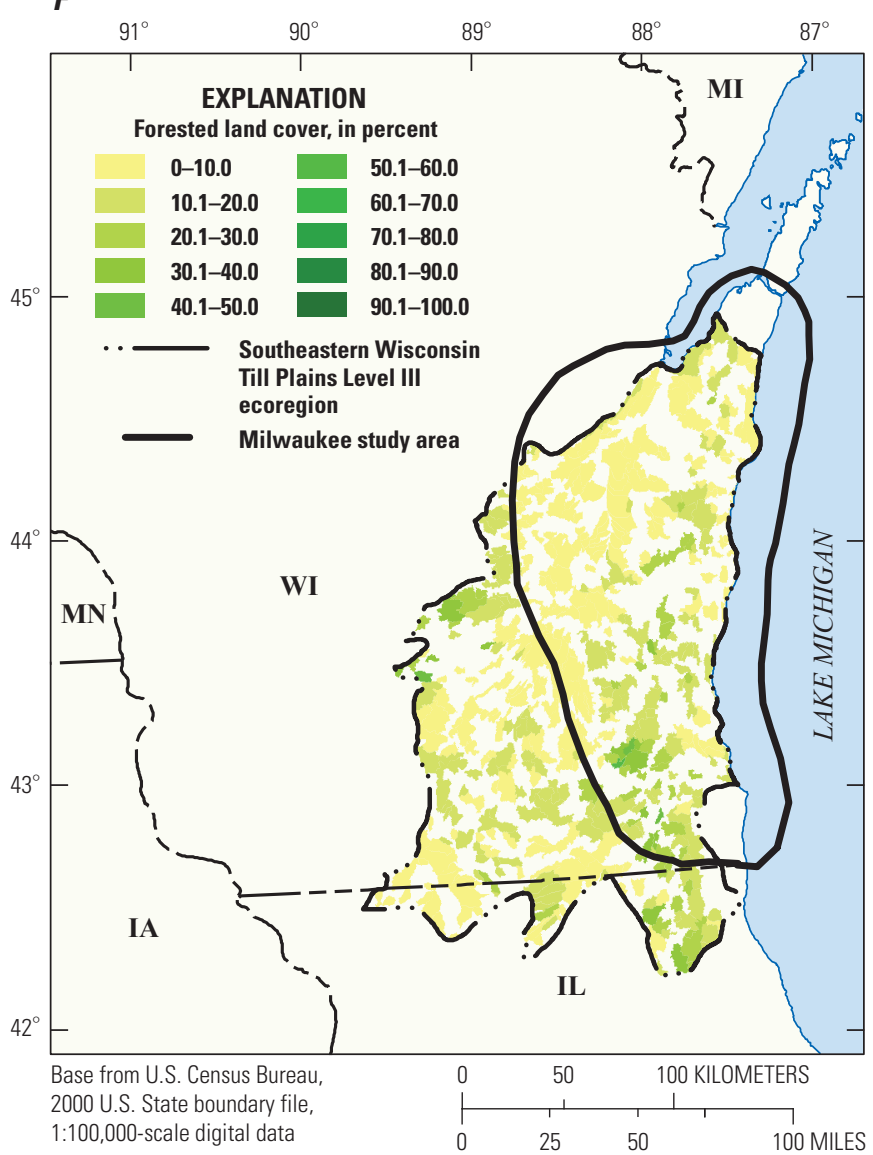

Figure 21-Continued. Summary of Southeastern Wisconsin Till Plains Level III ecoregion watershed characteristics, including $(A)$ average annual temperature, $(B)$ average annual precipitation, $(C)$ elevation, $(D)$ average slope, $(E)$ developed land cover, $(F)$ forested land cover, and $(G)$ agricultural land cover. 


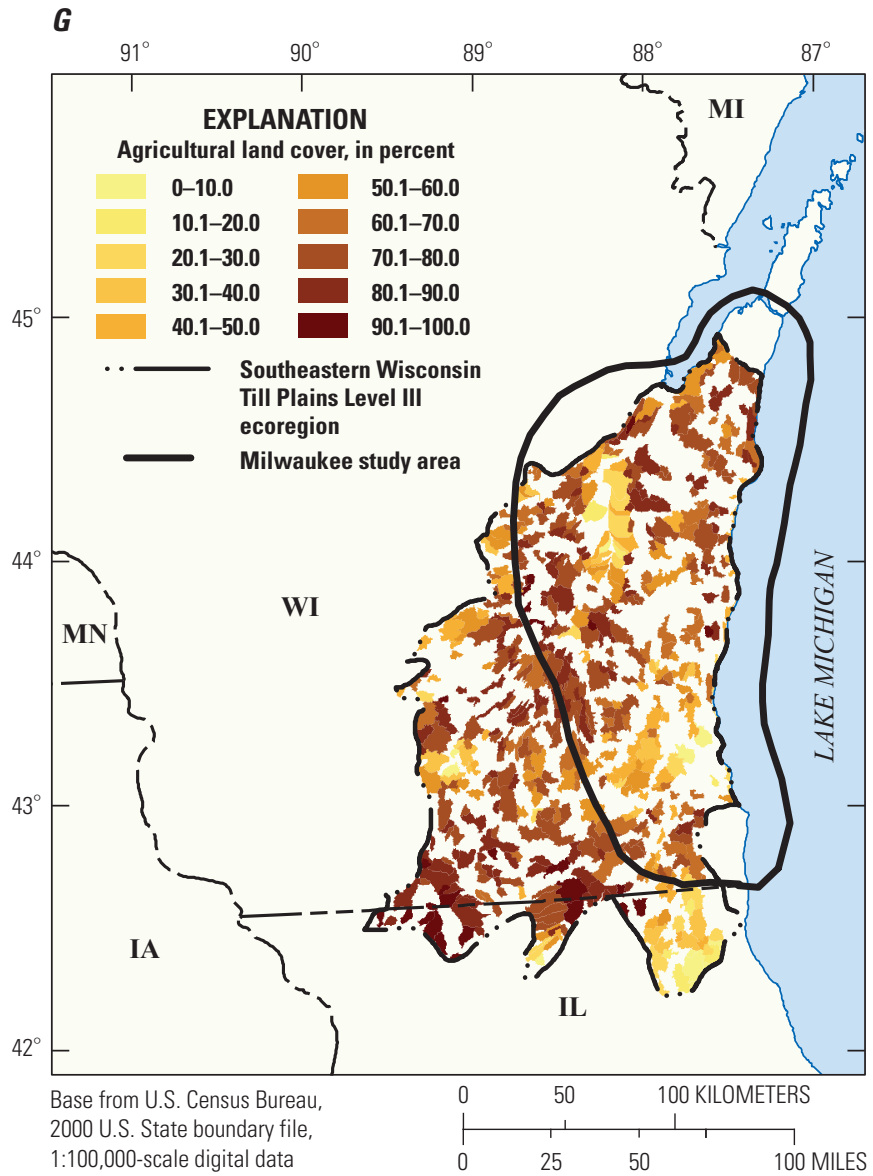

Figure 21-Continued. Summary of Southeastern Wisconsin Till Plains Level III ecoregion watershed characteristics, including $(A)$ average annual temperature, $(B)$ average annual precipitation, $(C)$ elevation, $(D)$ average slope, $(E)$ developed land cover, $(F)$ forested land cover, and $(G)$ agricultural land cover. 

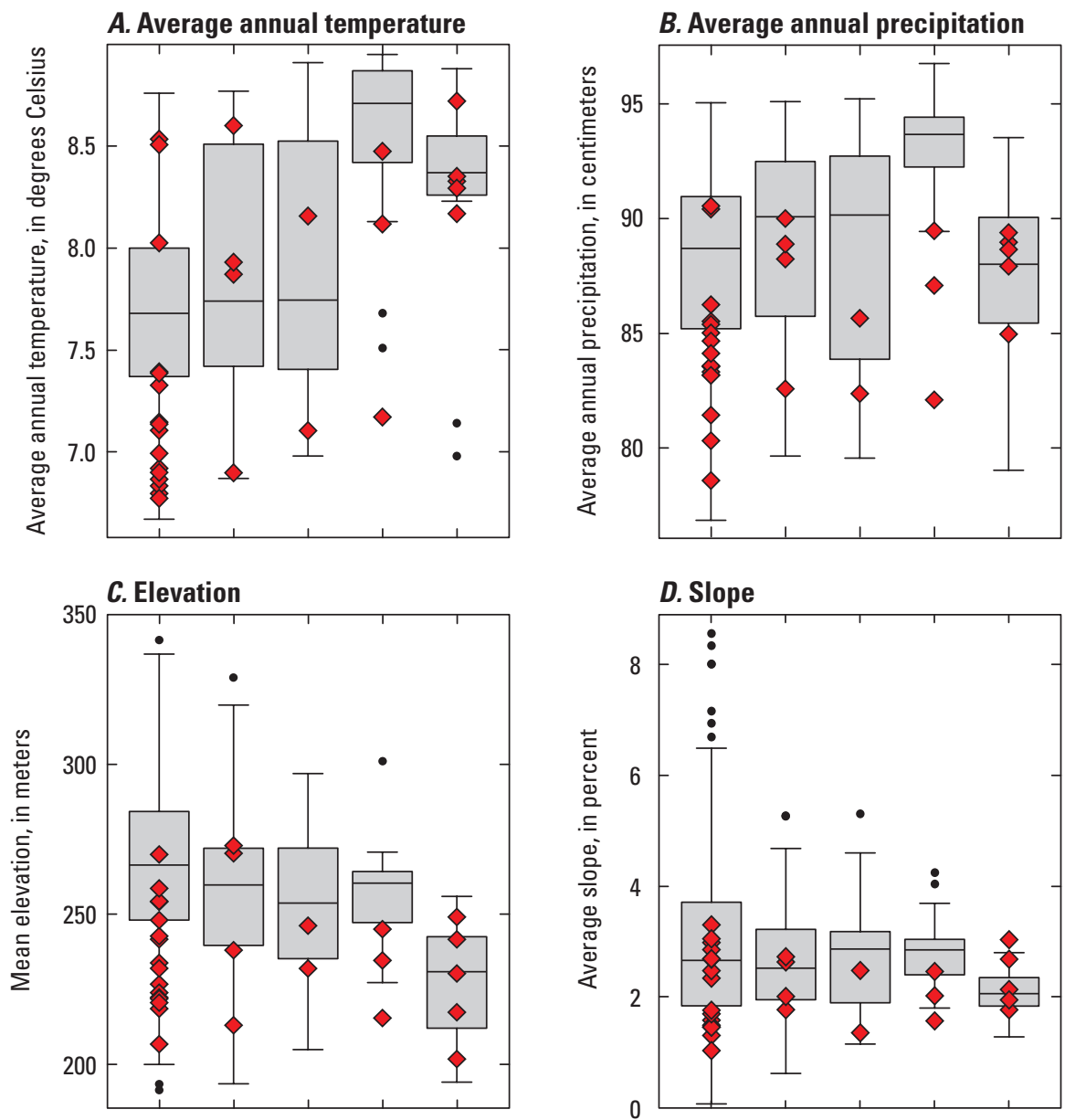

\section{EXPLANATION}

- Outlier

1.5 times the interquartile range

T above the box

$75^{\text {th }}$ percentile

\begin{tabular}{l|l} 
Median & Interquartile
\end{tabular}

$25^{\text {th }}$ percentile range

1.5 times the interquartile range below the box

$\diamond \quad$ EUSE values within development class
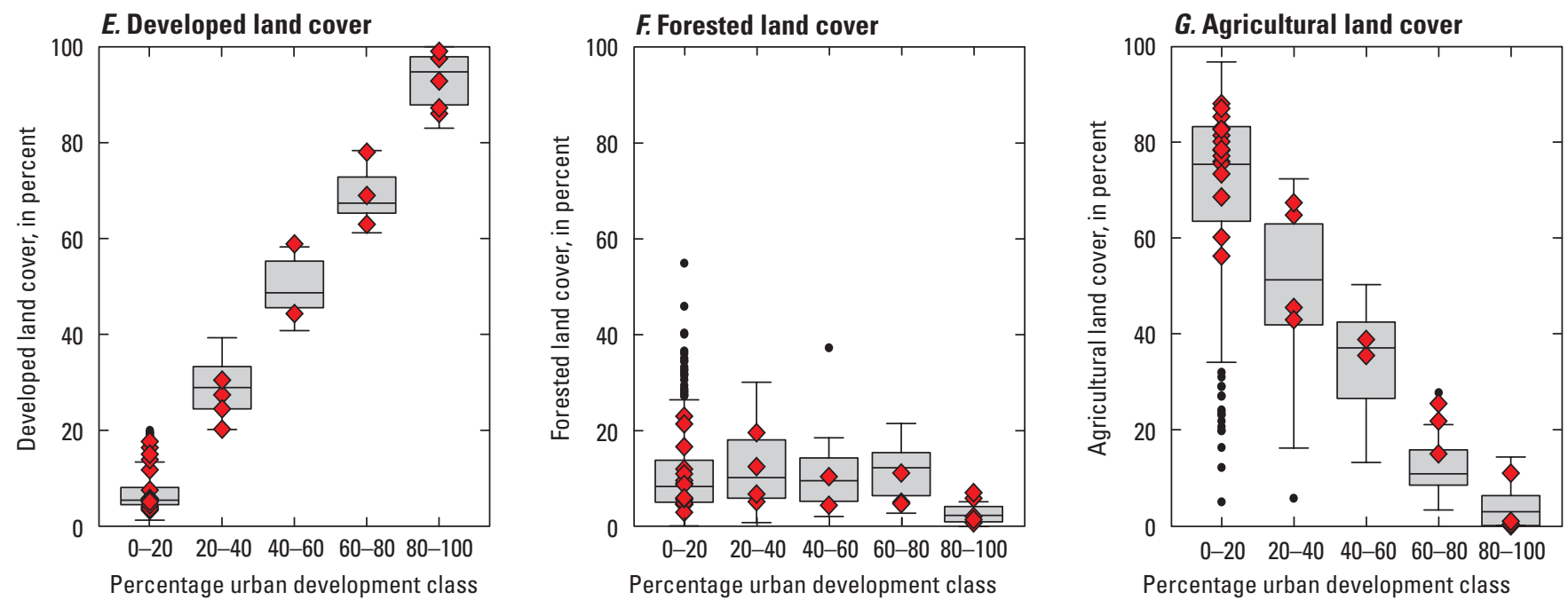

Figure 22. Summary of Southeastern Wisconsin Till Plains Level III ecoregion and Milwaukee EUSE study watershed characteristics by percentage of urban development class. $A$, Average annual temperature. $B$, Average annual precipitation. $C$, Mean elevation. D, Average slope. E, Developed land cover. F, Forested land cover. G, Agricultural land cover. 

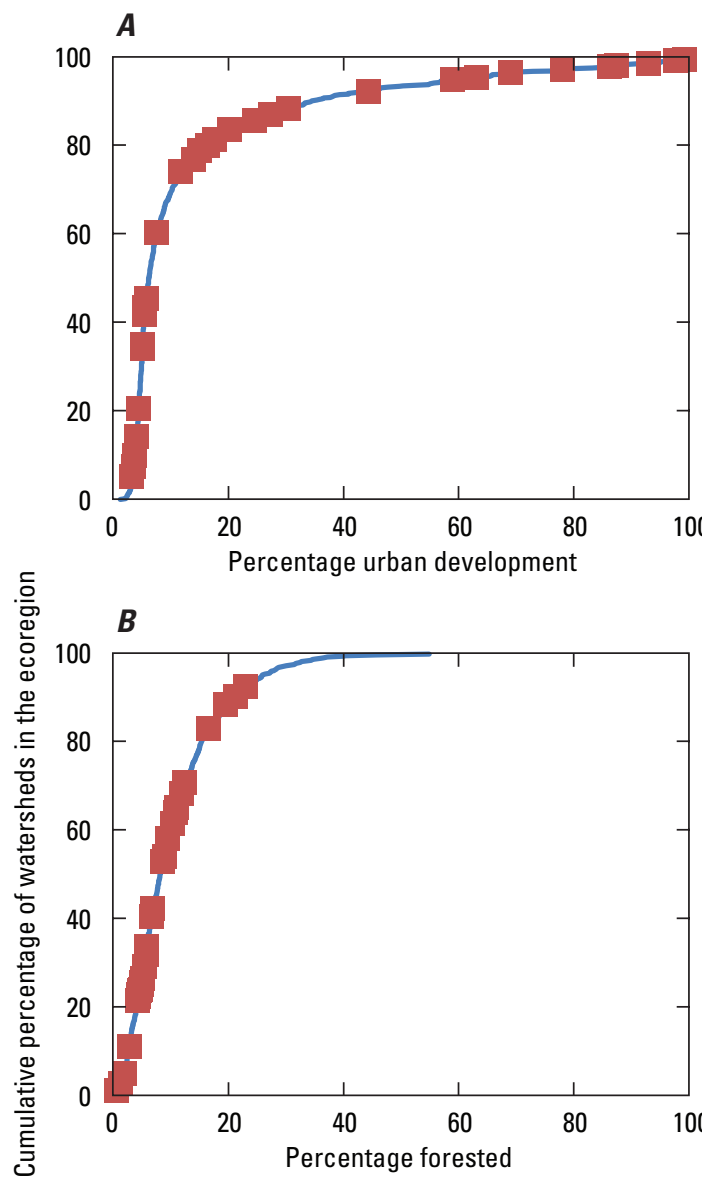

EXPLANATION

Distribution of land-cover characteristics within ecoregion watersheds EUSE study watersheds

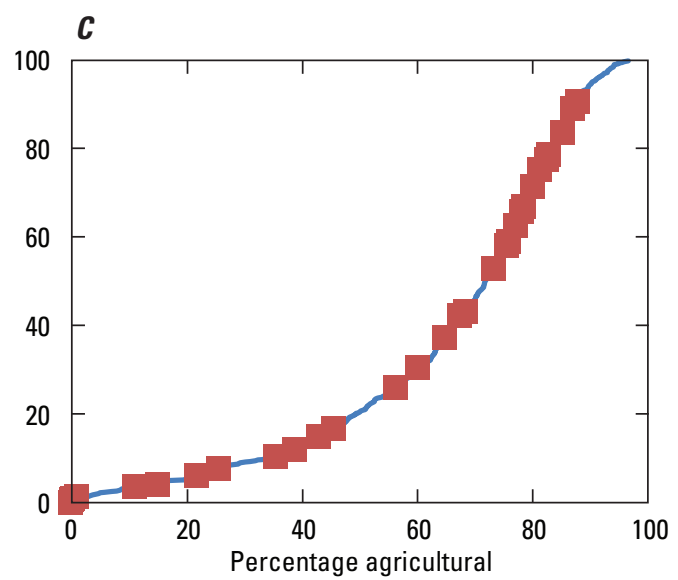

Figure 23. Cumulative distribution plot (blue line) of the percentage of $(A)$ urban development, $(B)$ forested, and $(C)$ agricultural land cover in the Southeastern Wisconsin Till Plains Level III ecoregion watersheds, and the percentage of the same land-cover types in the Milwaukee EUSE study watersheds. 


\section{Birmingham}

The 30 Birmingham, Alabama, EUSE study watersheds are located in the Ridge and Valley Level III ecoregion in Georgia and Alabama in the southeastern United States, where mountain ridges are typically sandstone, and valley floors are primarily limestone or shale (Johnson and others, 2002; app. 1). The climate is warm and humid with rainfall evenly distributed throughout the year, except for a dry period in August to October (Johnson and others, 2002).

Major metropolitan centers in the study area include Birmingham, Anniston, and Gadsden, Alabama (Johnson and others, 2002). The combined 2000 population for these three cities was 1.3 million, an 8 percent increase from 1990 (U.S. Census Bureau, 2009). The dominant natural vegetative cover is Appalachian oak forest, and land use is predominantly cropland, pasture, and urban lands (Johnson and others, 2002). Steel manufacturing is an important part of Birmingham's economy in addition to the medical, trade, finance, research, and government sectors (McKnight, 2004).

\section{Climate Variables}

The temperature and precipitation variables within the Ridge and Valley ecoregion watersheds vary considerably, in part because of the large north-south latitudinal range (tables 3, 5; figs. $24 A, B ; 25 A, B ; 26 A, B$ ). The average annual temperature in the ecoregion watersheds ranges from $6^{\circ} \mathrm{C}$ to $17^{\circ} \mathrm{C}$, and the average annual precipitation has a range of $70 \mathrm{~cm}$. The Birmingham EUSE study watersheds are located within the southern portion of the Ridge and Valley ecoregion, and the temperature reflects this. The average annual temperature for the EUSE watersheds ranged from $14.7^{\circ} \mathrm{C}$ to $16.8^{\circ} \mathrm{C}$, the average temperature is 4 degrees warmer than the temperature in the ecoregion watersheds. The average annual precipitation only ranged from 141.2 to 151.5 millimeters $(\mathrm{mm})$, although the median and mean were higher than the average annual precipitation in the ecoregion watersheds.

\section{Topographic Variables}

The topography of the Ridge and Valley ecoregion watersheds also varied more than the topography of the Birmingham EUSE study watersheds (fig. 24C, D). The elevation of the ecoregion ranged from 87 to $1,199 \mathrm{~m}$, reflecting greater relief than the EUSE watersheds, which ranged from 161 to $324 \mathrm{~m}$. The slopes were also more extreme in the ecoregion as a whole. The percentage slope ranged from 1 to 38 percent for the ecoregion watersheds and only 4 to 11 for the EUSE watersheds. The median values for the two areas are similar, with 10 and 11 percent for the ecoregion and EUSE watersheds, respectively. The K-W test shows that the slopes for the ecoregion and EUSE watersheds are drawn from the same population, but the elevation characteristics were significantly different.

\section{Land-Cover Variables}

The range of values for developed land in the Birmingham EUSE watersheds extends over the range of values for the Ridge and Valley ecoregion as a whole (figs. 24E, 26E, $27 A$ ). The ecoregion has a lower median and $75^{\text {th }}$ percentile of developed land than the EUSE sites, indicating that there are relatively few watersheds in the population of ecoregion watersheds with more than 10 percent developed land. The range and median of both the forested and agricultural landcover percentages are greater for the population of ecoregion watersheds than for the EUSE watersheds (figs. 24E, $26 F, G)$. The land cover in the Ridge and Valley ecoregion is predominantly forest, and the undeveloped land in the EUSE watersheds is also predominantly forest. 

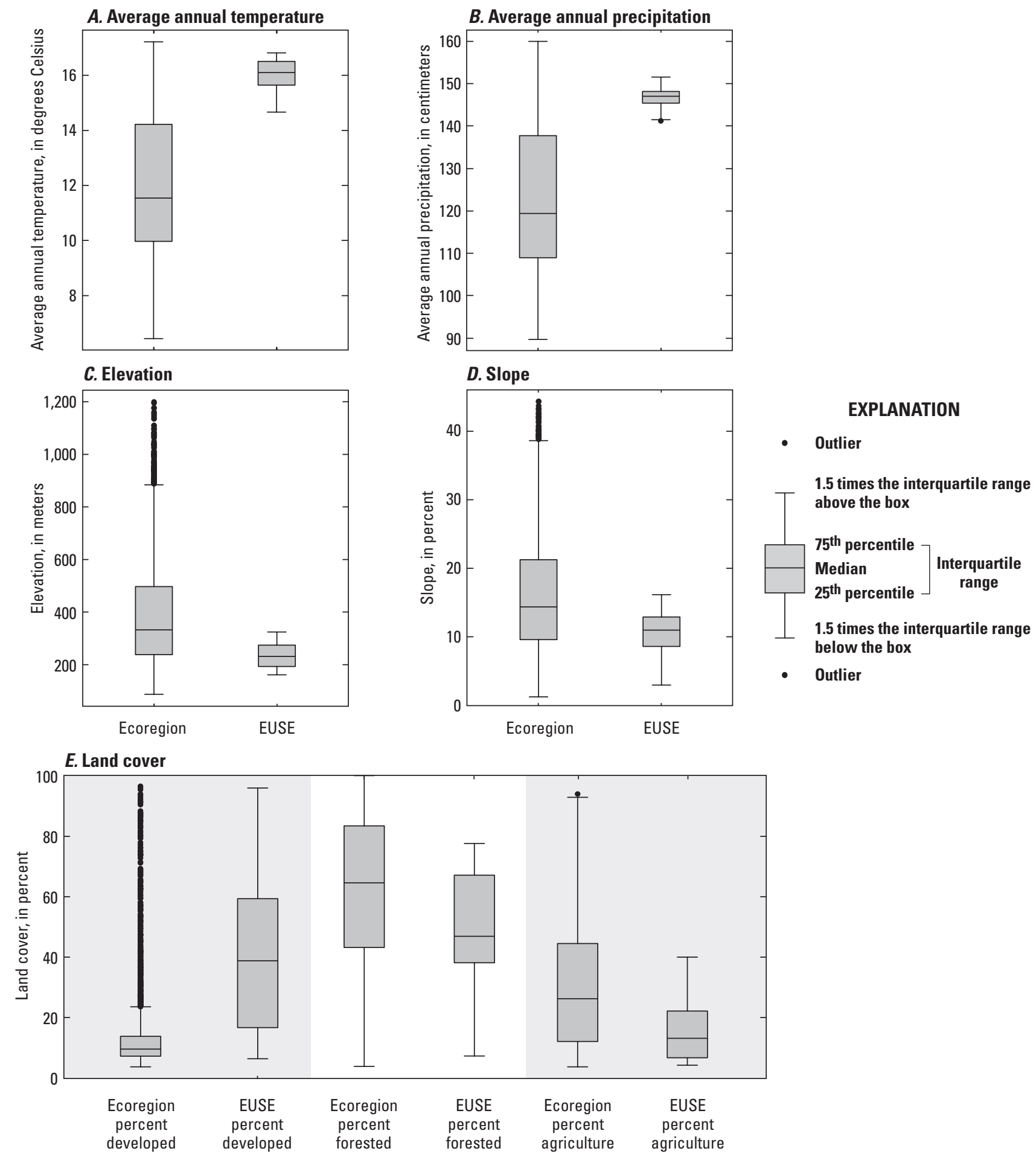

Figure 24. Summary of Ridge and Valley Level III ecoregion and Birmingham EUSE study watershed characteristics, including $(A)$ average annual temperature, $(B)$ average annual precipitation, $(C)$ elevation, $(D)$ percent slope, and $(E)$ percent land cover. 
$\boldsymbol{A}$

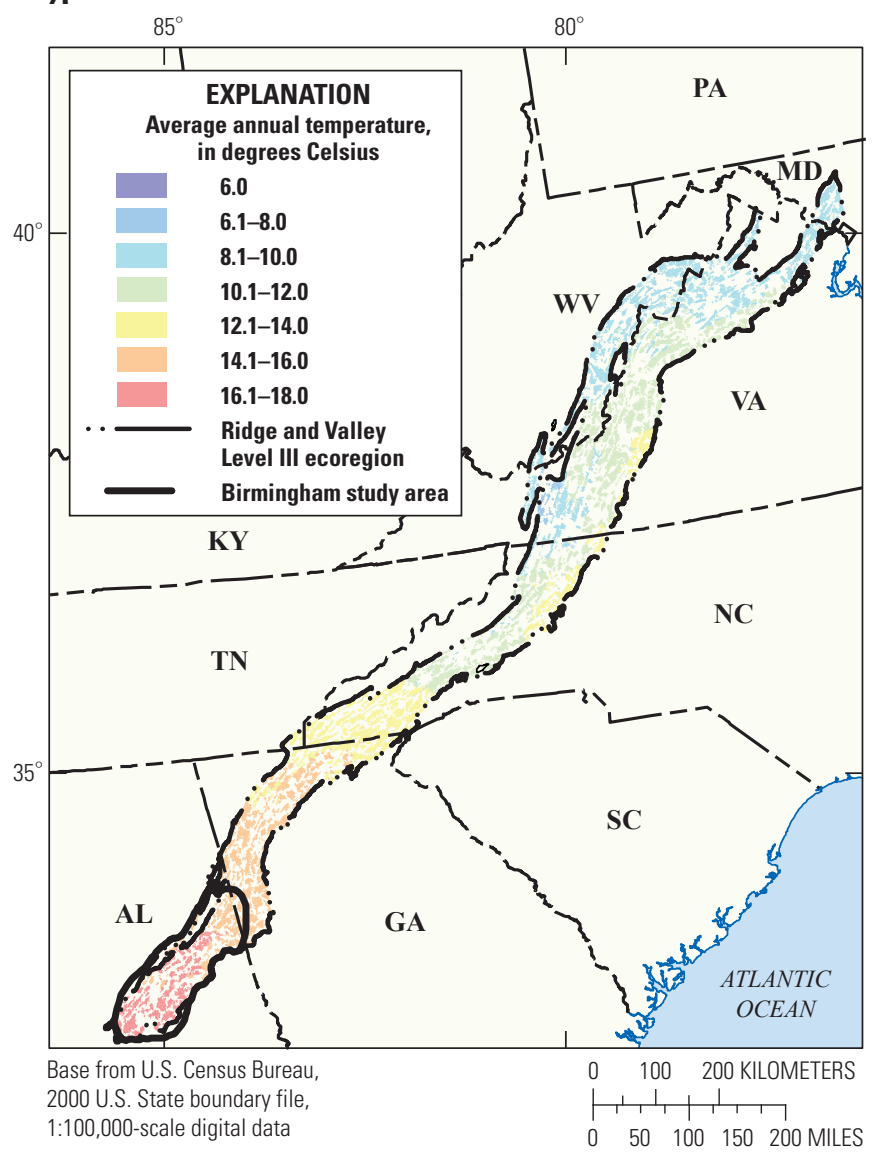

$B$

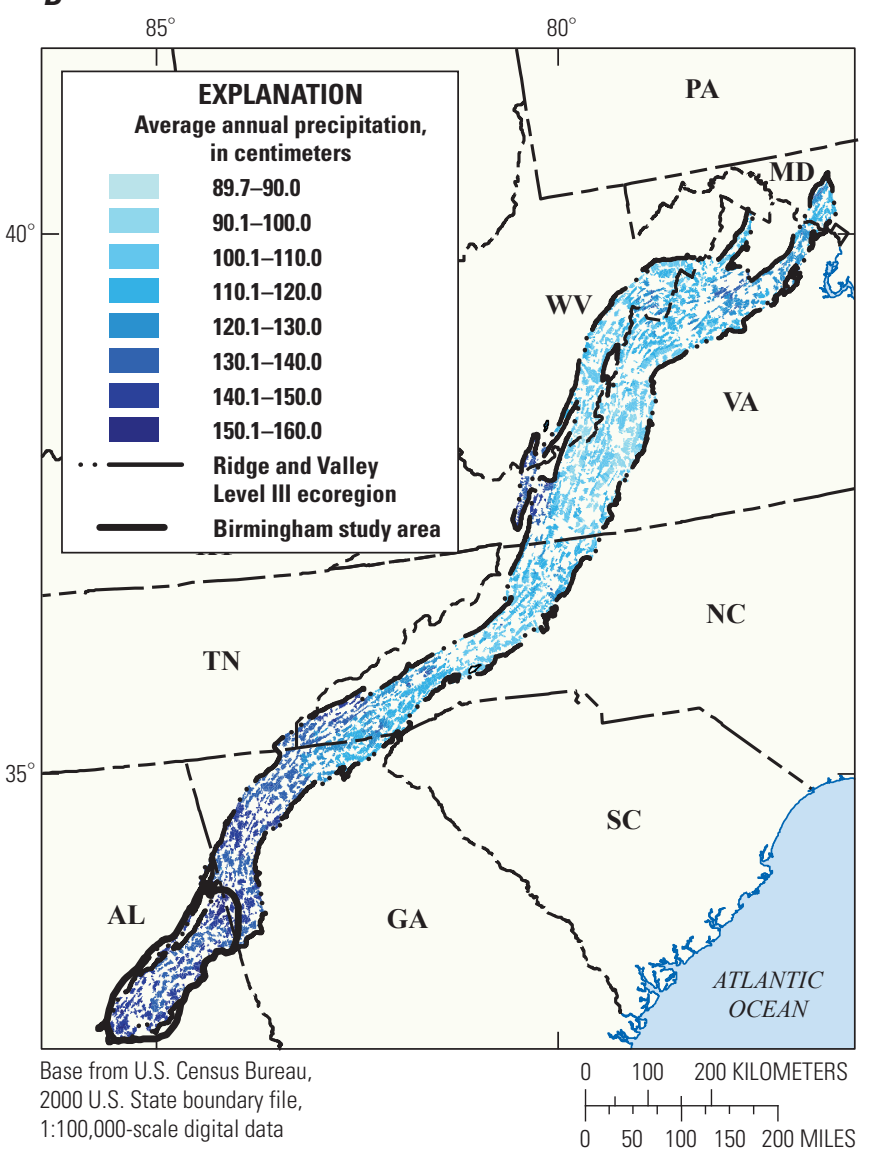

Figure 25. Summary of Ridge and Valley Level III ecoregion watershed characteristics, including $(A)$ average annual temperature, $(B)$ average annual precipitation, $(C)$ elevation, $(D)$ average slope, $(E)$ developed land cover, $(F)$ forested land cover, and $(G)$ agricultural land cover. 


\section{C}

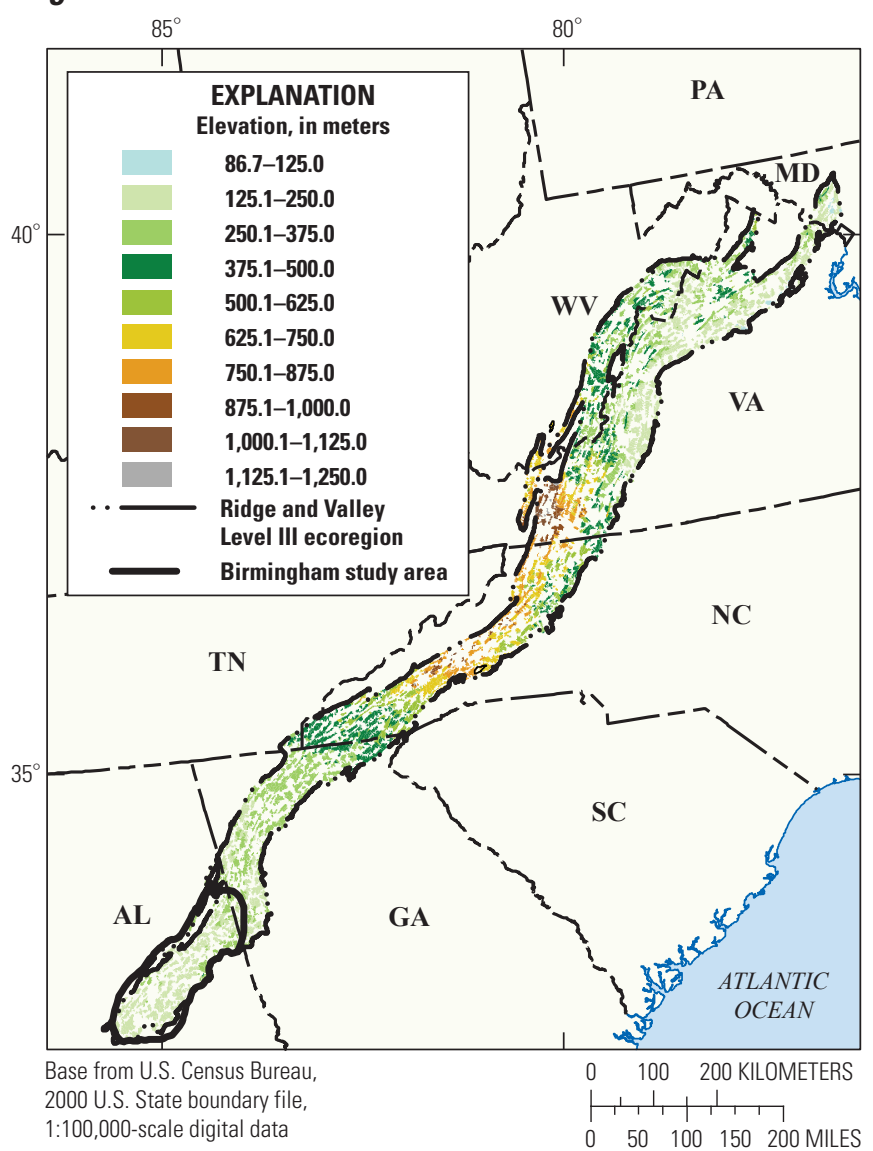

D

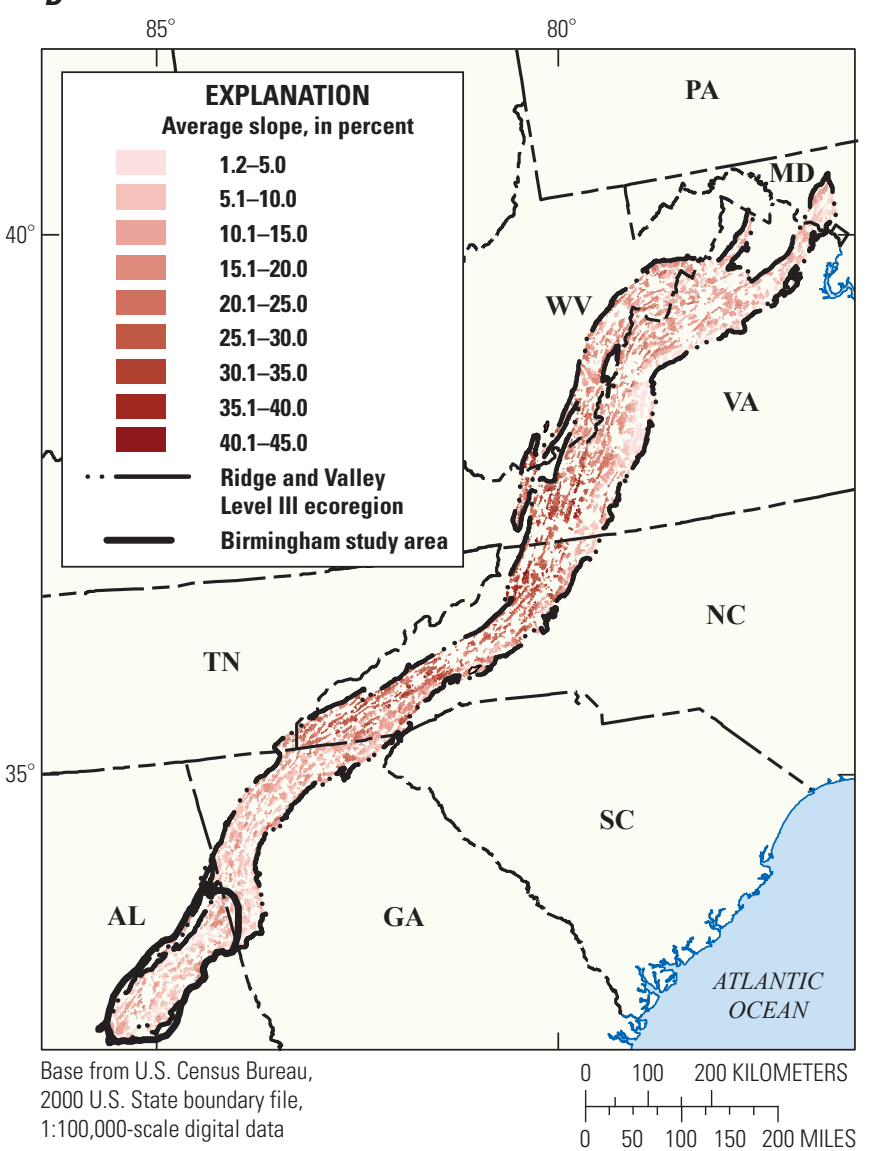

Figure 25-Continued. Summary of Ridge and Valley Level III ecoregion watershed characteristics, including $(A)$ average annual temperature, $(B)$ average annual precipitation, $(C)$ elevation, $(D)$ average slope, $(E)$ developed land cover, $(F)$ forested land cover, and $(G)$ agricultural land cover. 
$E$

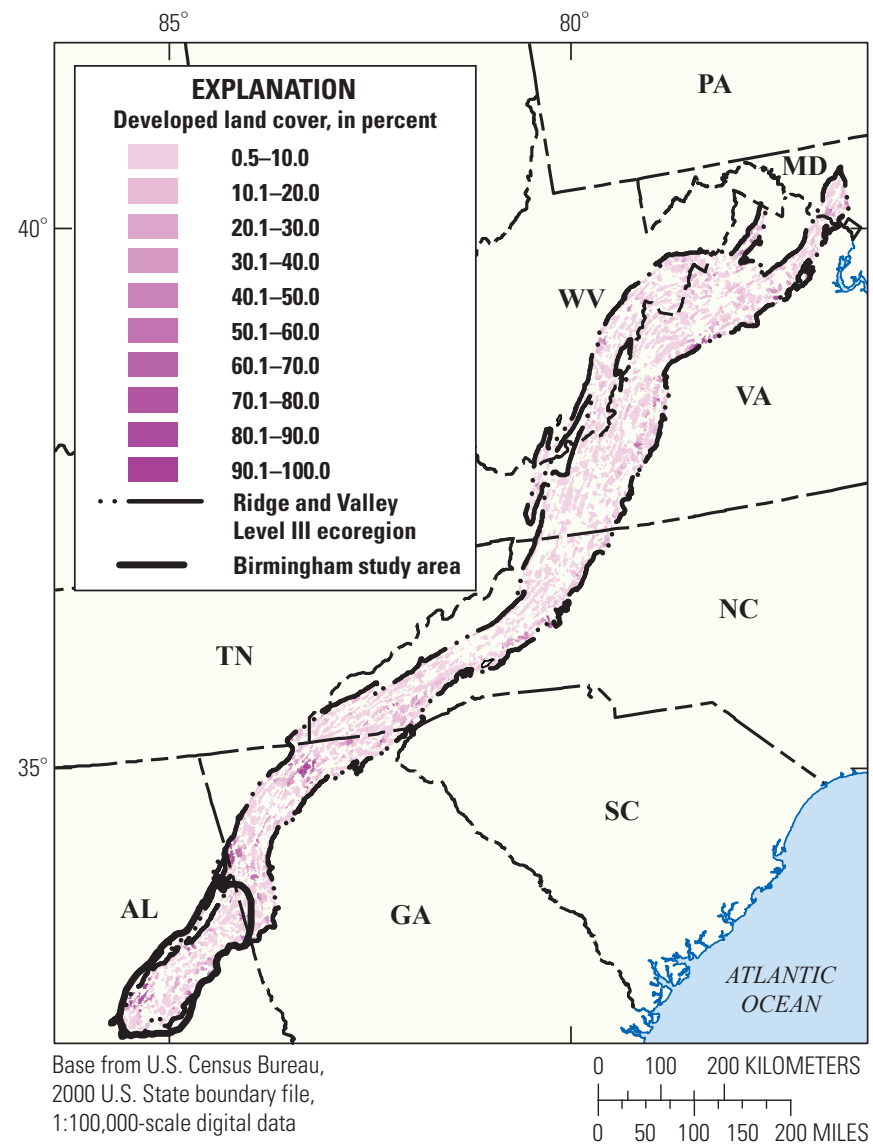

F

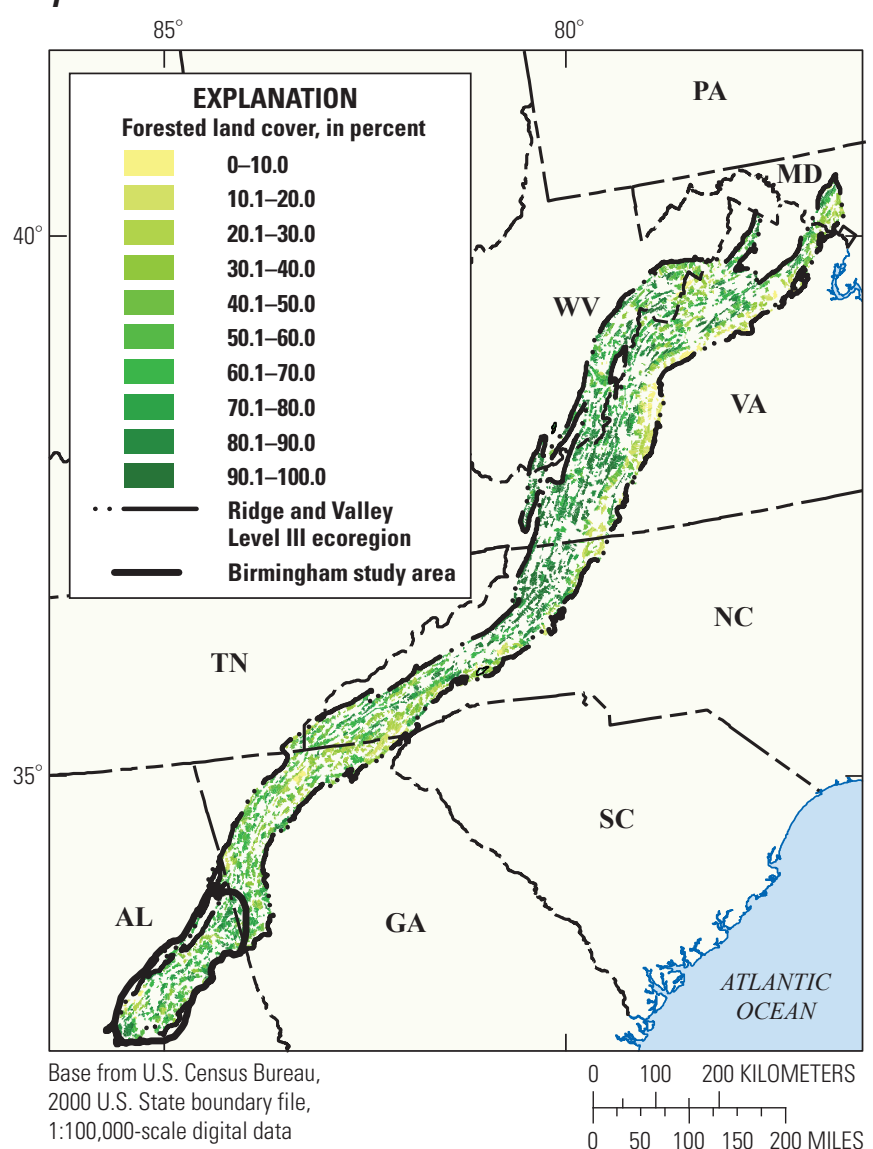

Figure 25-Continued. Summary of Ridge and Valley Level III ecoregion watershed characteristics, including $(A)$ average annual temperature, $(B)$ average annual precipitation, $(C)$ elevation, $(D)$ average slope, $(E)$ developed land cover, $(F)$ forested land cover, and $(G)$ agricultural land cover. 
G

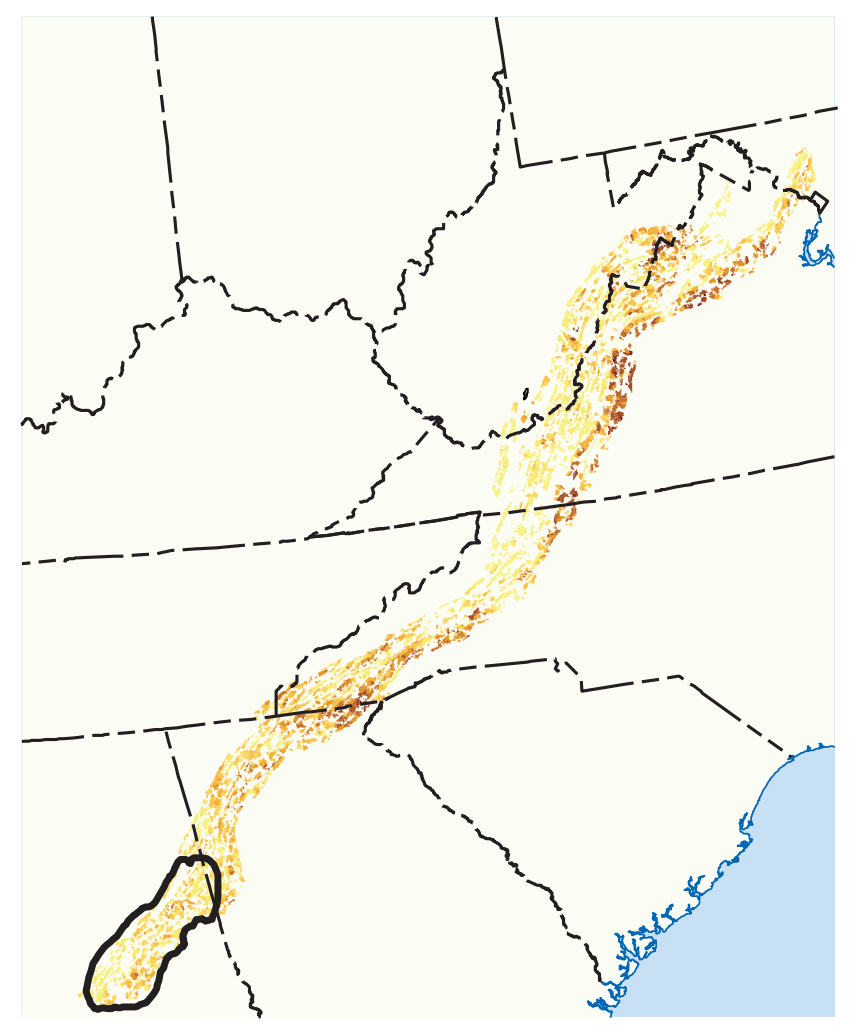



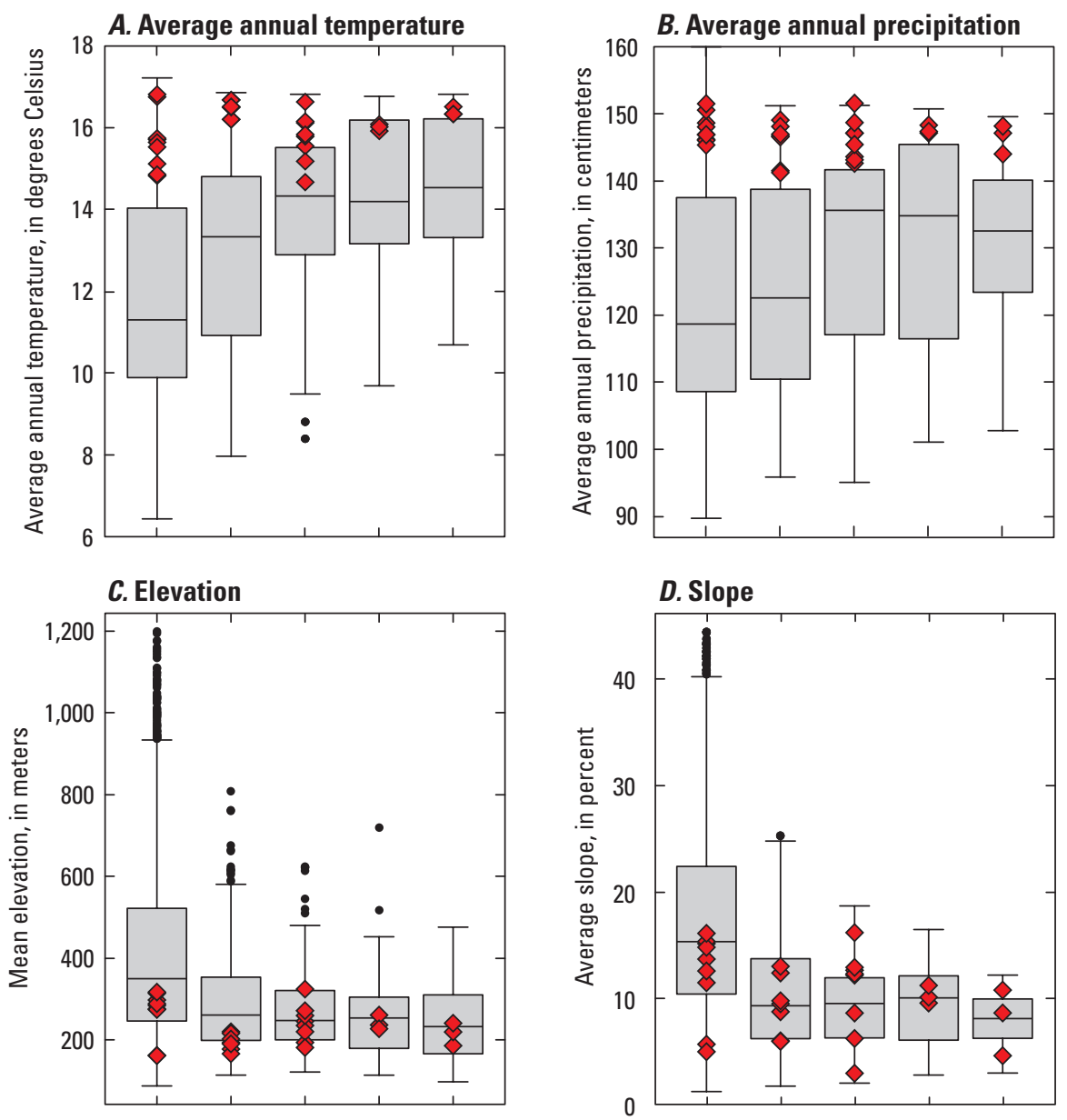

\section{EXPLANATION}

- Outlier

1.5 times the interquartile range above the box

75th percentile

Median

Interquartile

$25^{\text {th }}$ percentile range

1.5 times the interquartile range below the box

$\diamond \quad$ EUSE values within development class
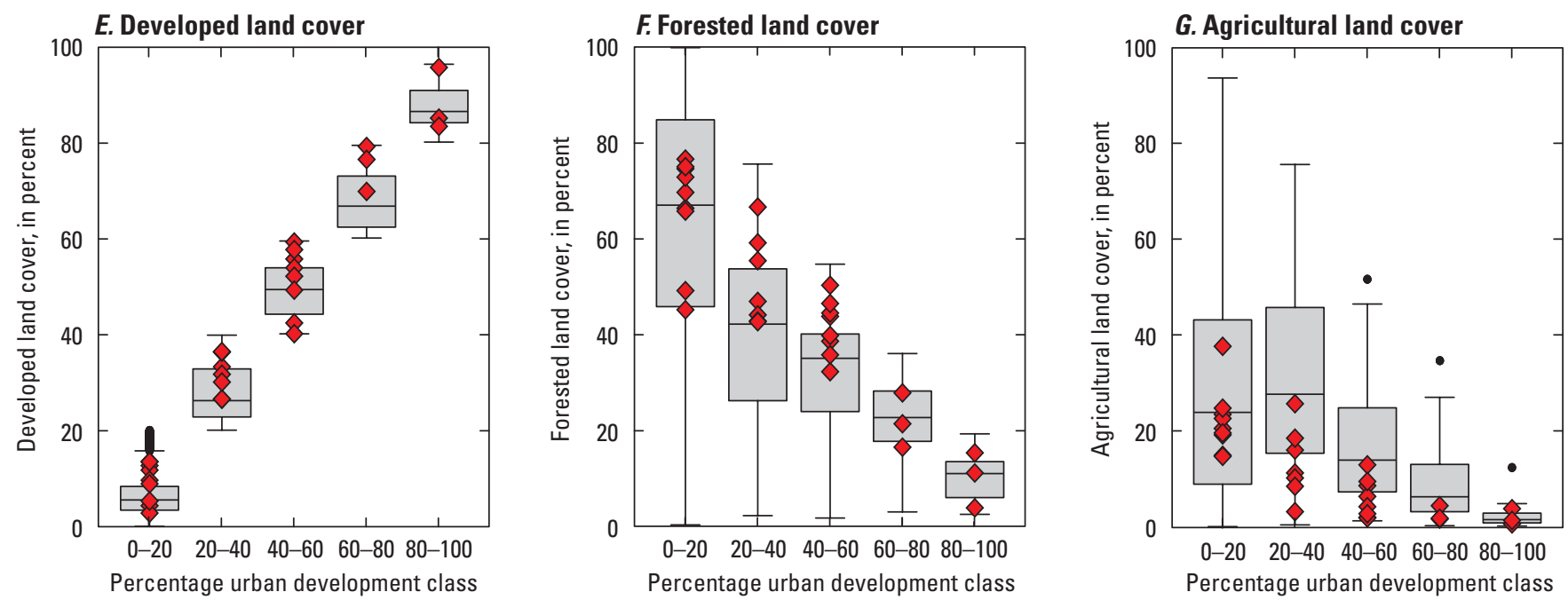

Figure 26. Summary of Ridge and Valley Level III ecoregion and Birmingham EUSE study watershed characteristics by percentage of urban development class. $A$, Average annual temperature. $B$, Average annual precipitation. $C$, Mean elevation. $D$, Average slope. $E$, Developed land cover. F, Forested land cover. G, Agricultural land cover. 

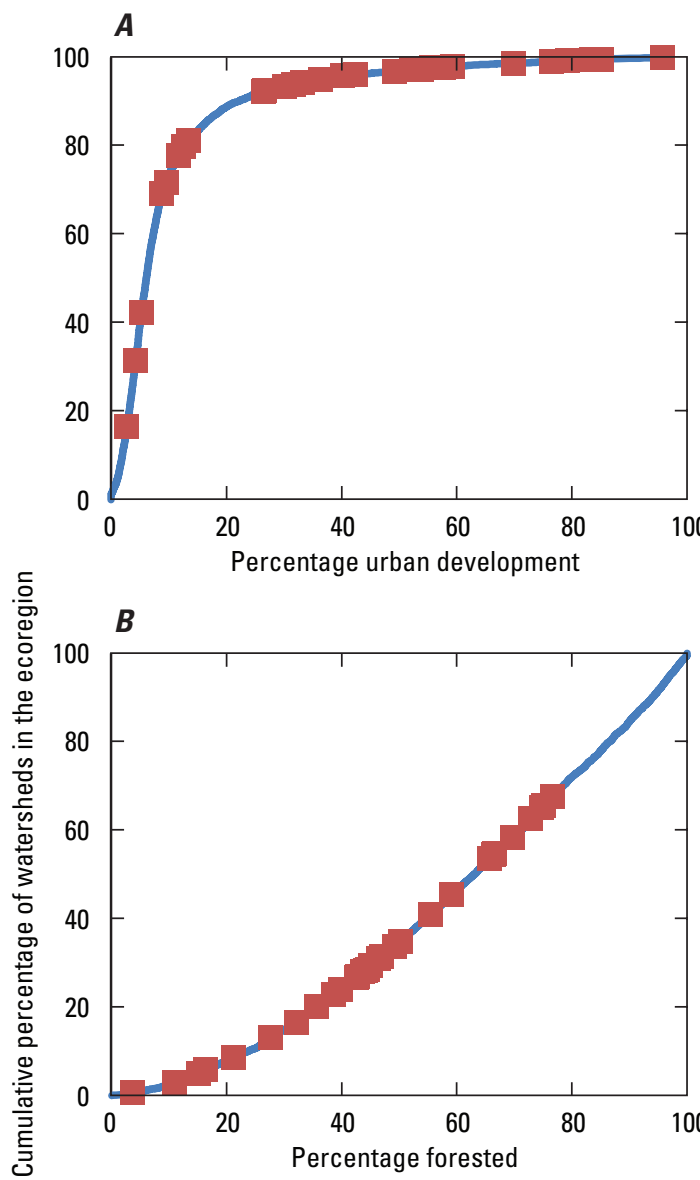

EXPLANATION

Distribution of land-cover characteristics within ecoregion watersheds

EUSE study watersheds

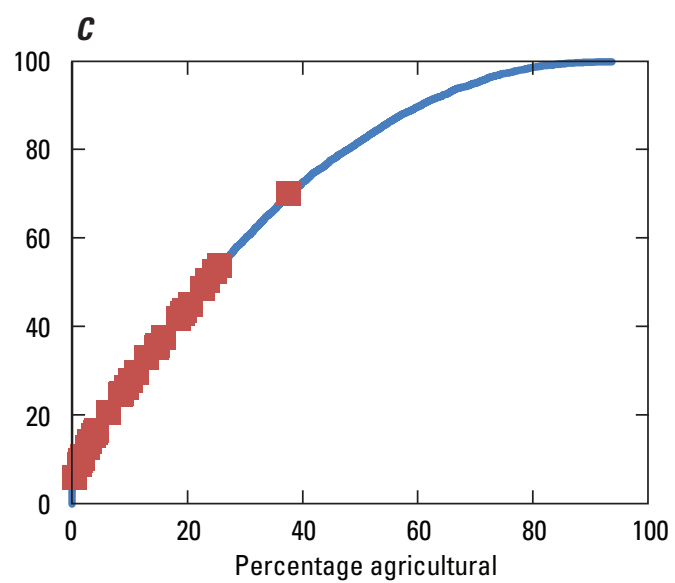

Figure 27. Cumulative distribution plot (blue line) of the percentage of $(A)$ urban development, $(B)$ forested, and $(C)$ agricultural land cover in the Ridge and Valley Level III ecoregion watersheds, and the percentage of the same land-cover types in the Birmingham EUSE study watersheds. 


\section{Atlanta}

The 30 Atlanta, Georgia, EUSE study watersheds are located in the Piedmont Level III ecoregion, which is characterized by gently rolling topography and dissected irregular plains (app. 1). The soils are almost exclusively fine-grained sediments (Giddings and others, 2009). The climate is relatively warm and humid with precipitation relatively consistent throughout the year, typical of the southeastern United States. Streams in the area typically have low to moderate gradients with cobble, gravel, and sandy substrates (Couch and others, 1996).

Three major population centers of the study area are Atlanta, Sandy Springs, and Marietta with a combined 2000 population of 4,247,981, a 38.4 percent increase from 1990 (U.S. Census Bureau, 2009). Natural land cover in the Atlanta study area is oak-hickory-pine forest; however, current (2011) land use and land cover include forested areas in silviculture and agricultural production of hay, cattle and poultry, and sprawling urban development (Falcone and others, 2007). The economy is diversified and includes medical, industrial, commercial, and service sectors (McKnight, 2004).

\section{Climate Variables}

Average annual temperatures in the Piedmont ecoregion watersheds range from $12.8^{\circ} \mathrm{C}$ to $17.7^{\circ} \mathrm{C}$, and temperatures in the Atlanta EUSE watersheds ranged from $15.6^{\circ} \mathrm{C}$ to $17.5^{\circ} \mathrm{C}$ (table 3; figs. $28 A, B, 29 A, B, 30 A, B$ ). The minimum temperature value in the EUSE watersheds is above the median value in the ecoregion population. The average annual precipitation in the Piedmont ecoregion watersheds ranges from 108.1 to $168.6 \mathrm{~cm}$, a range of more than $60 \mathrm{~cm}$. The minimum precipitation value in the EUSE watersheds is also above the median value in the ecoregion. The range of average annual precipitation in the Atlanta EUSE watersheds is less than $19 \mathrm{~cm}$ with higher ranges in the lesser developed quintiles of watersheds.

\section{Topographic Variables}

The elevation and slopes within the Piedmont ecoregion vary widely from the eastern edge, bordering the coastal plain, to the western boundary along the Ridge and Valley ecoregion (figs. 28C, $D ; 29 C, D$ ). The range in elevation of the Piedmont ecoregion watersheds is much broader than that of the Atlanta EUSE watersheds, although with a lower median value. The range in percentage slope of the EUSE watersheds is smaller than the range across the ecoregion, although with a higher median value. The percentage slope values of the ecoregion and EUSE watersheds do not show a significant difference using the $\mathrm{K}-\mathrm{W}$ test.

\section{Land-Cover Variables}

The range of developed land values in the Atlanta EUSE watersheds includes the range of values that exists in the Piedmont ecoregion as a whole (figs. 28E, 30E, 31A). The ecoregion has a lower median and $75^{\text {th }}$ percentile of developed land than the EUSE sites, indicating that there are relatively few watersheds in the population of ecoregion watersheds with more than 10 percent developed land, and only 12 watersheds in the upper 20th percentile, with only one from the EUSE watersheds in this quintile (table 4). The range and median values of the forested land-cover percentages are greater for the population of ecoregion watersheds than for the EUSE watersheds (figs. 28E, 31B). The land cover in the Piedmont ecoregion is predominantly forest, and the undeveloped land in the Atlanta EUSE watersheds is also predominantly forest. 

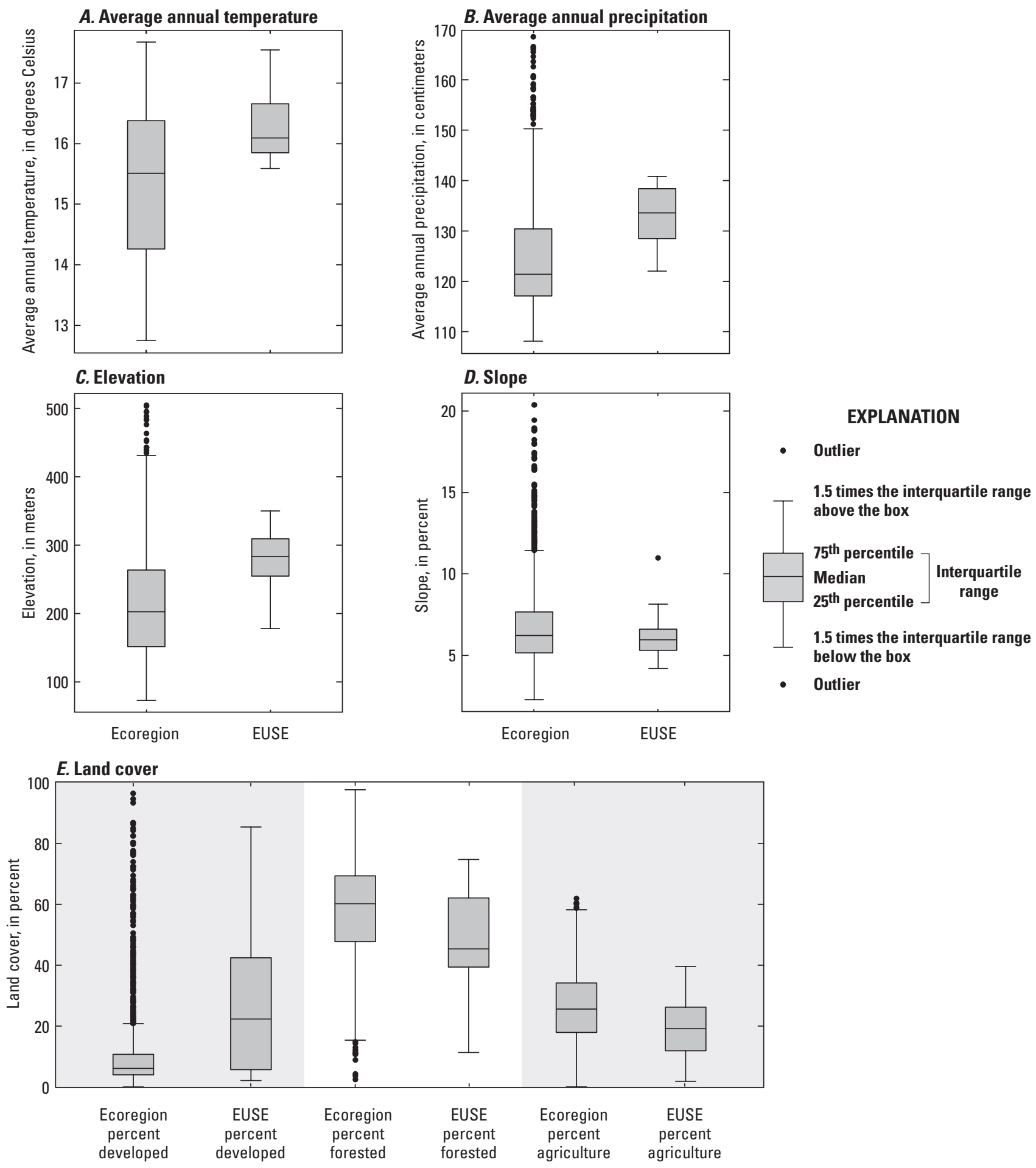

Figure 28. Summary of Piedmont Level III ecoregion and Atlanta EUSE study watershed characteristics, including $(A)$ average annual temperature, $(B)$ average annual precipitation, $(C)$ elevation, $(D)$ percent slope, and $(E)$ percent land cover. 
$\boldsymbol{A}$

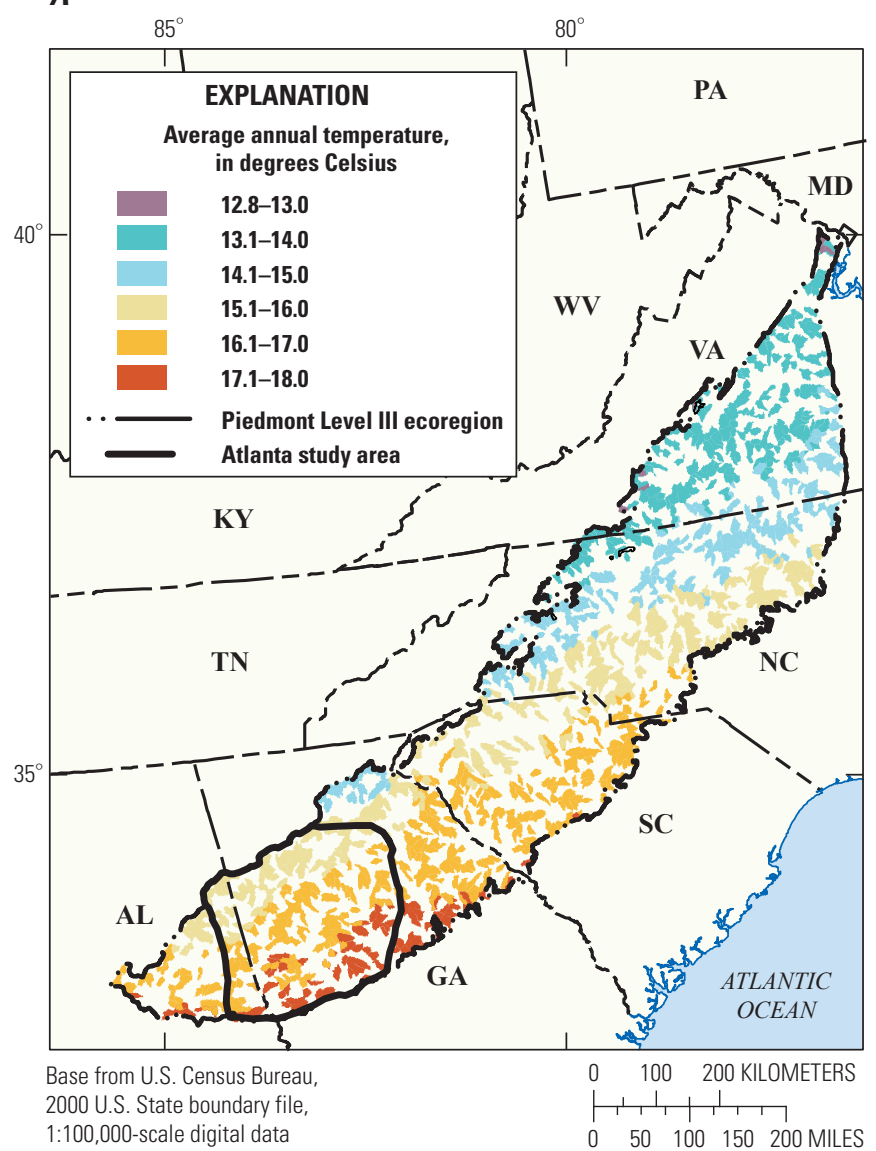

$B$

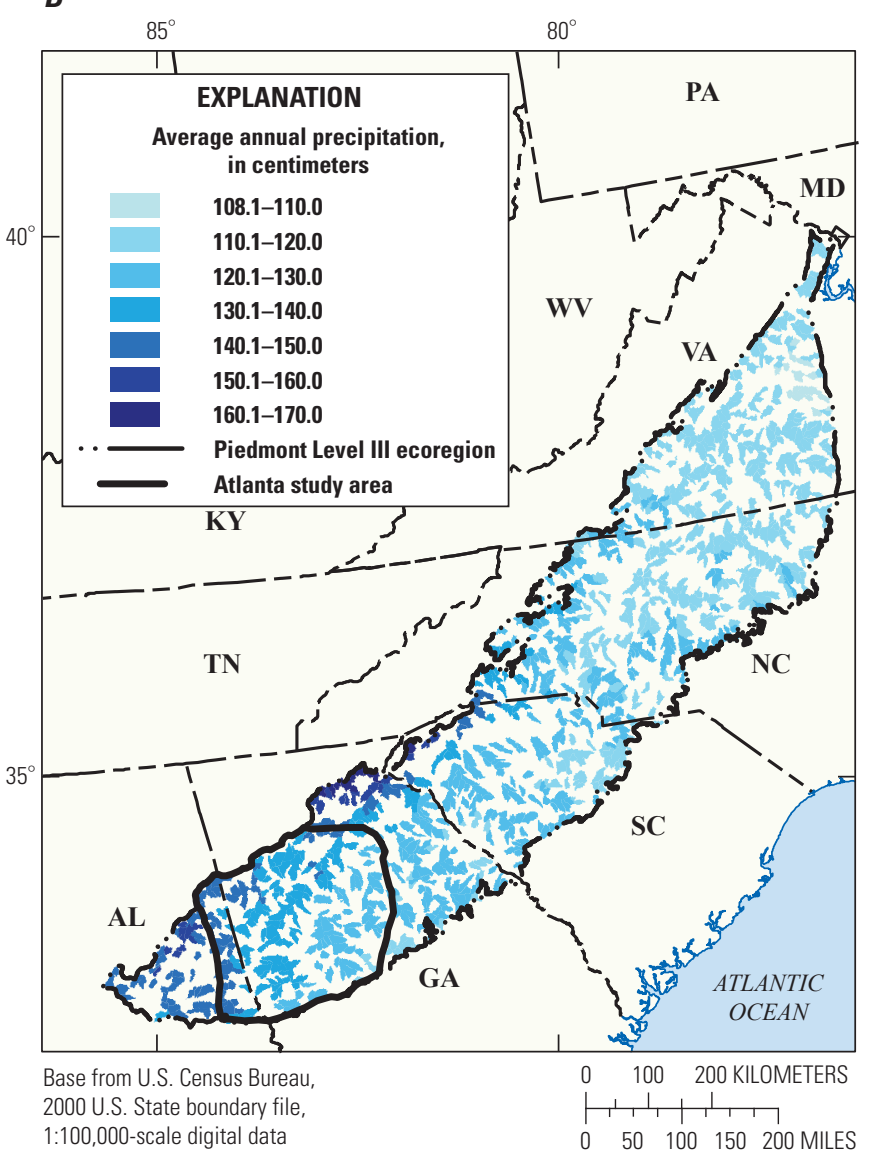

Figure 29. Summary of Piedmont Level III ecoregion watershed characteristics in the vicinity of Atlanta, including $(A)$ average annual temperature, $(B)$ average annual precipitation, $(C)$ elevation, $(D)$ average slope, $(E)$ developed land cover, $(F)$ forested land cover, and $(G)$ agricultural land cover. 
C

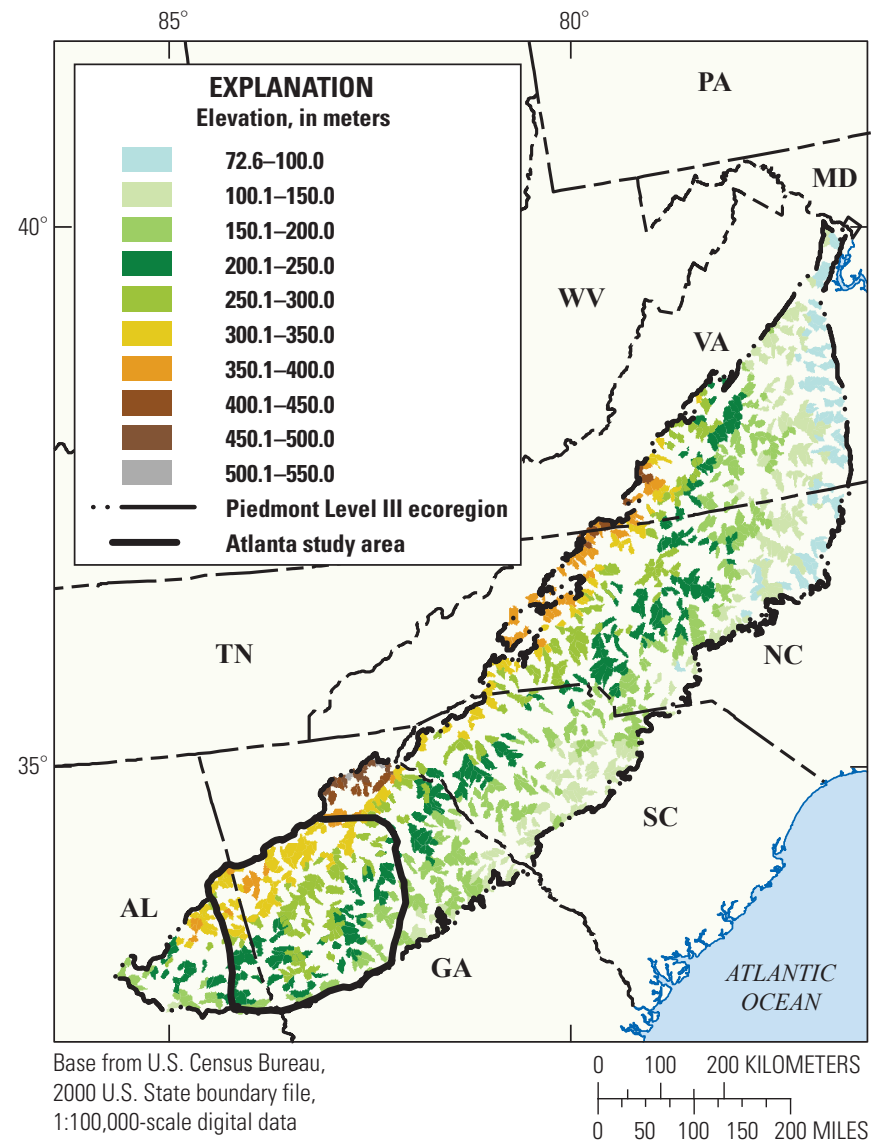

D

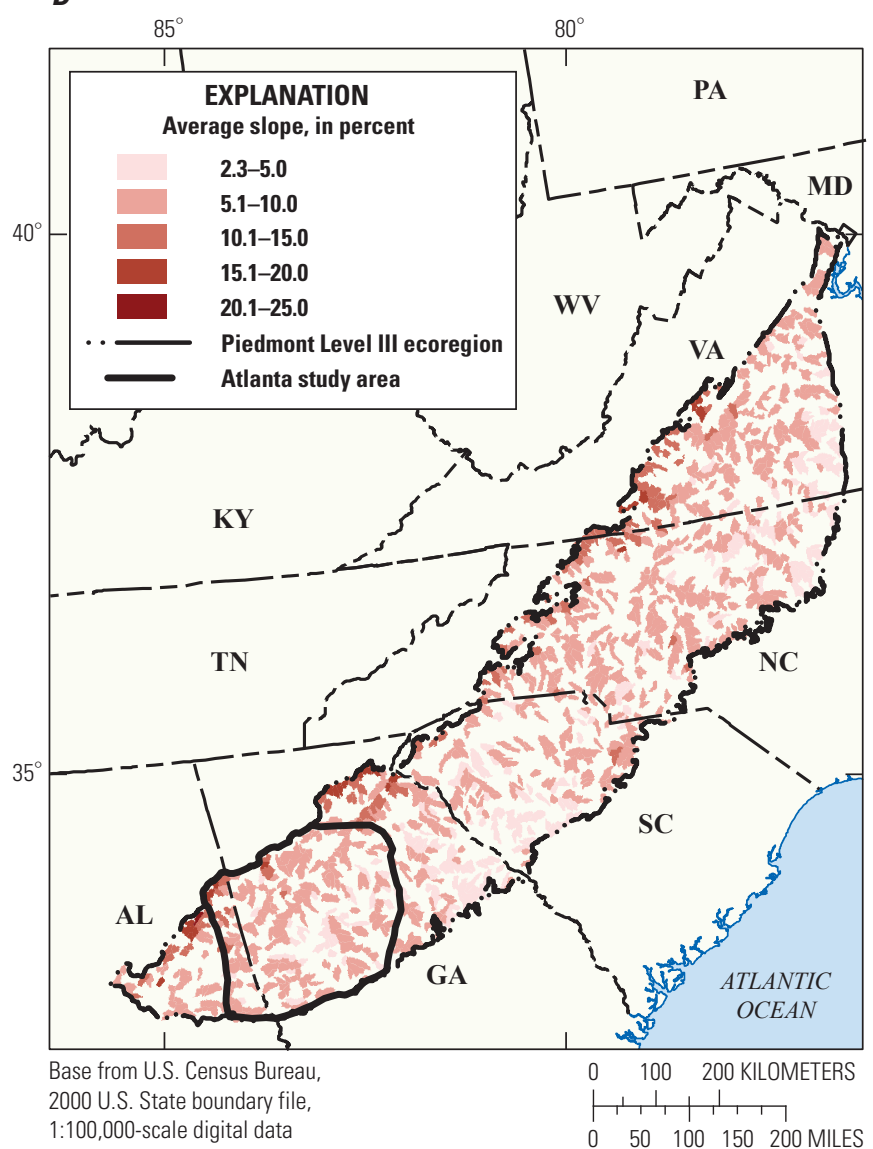

Figure 29-Continued. Summary of Piedmont Level III ecoregion watershed characteristics in the vicinity of Atlanta, including $(A)$ average annual temperature, $(B)$ average annual precipitation, $(C)$ elevation, $(D)$ average slope, $(E)$ developed land cover, $(F)$ forested land cover, and $(G)$ agricultural land cover. 
$E$

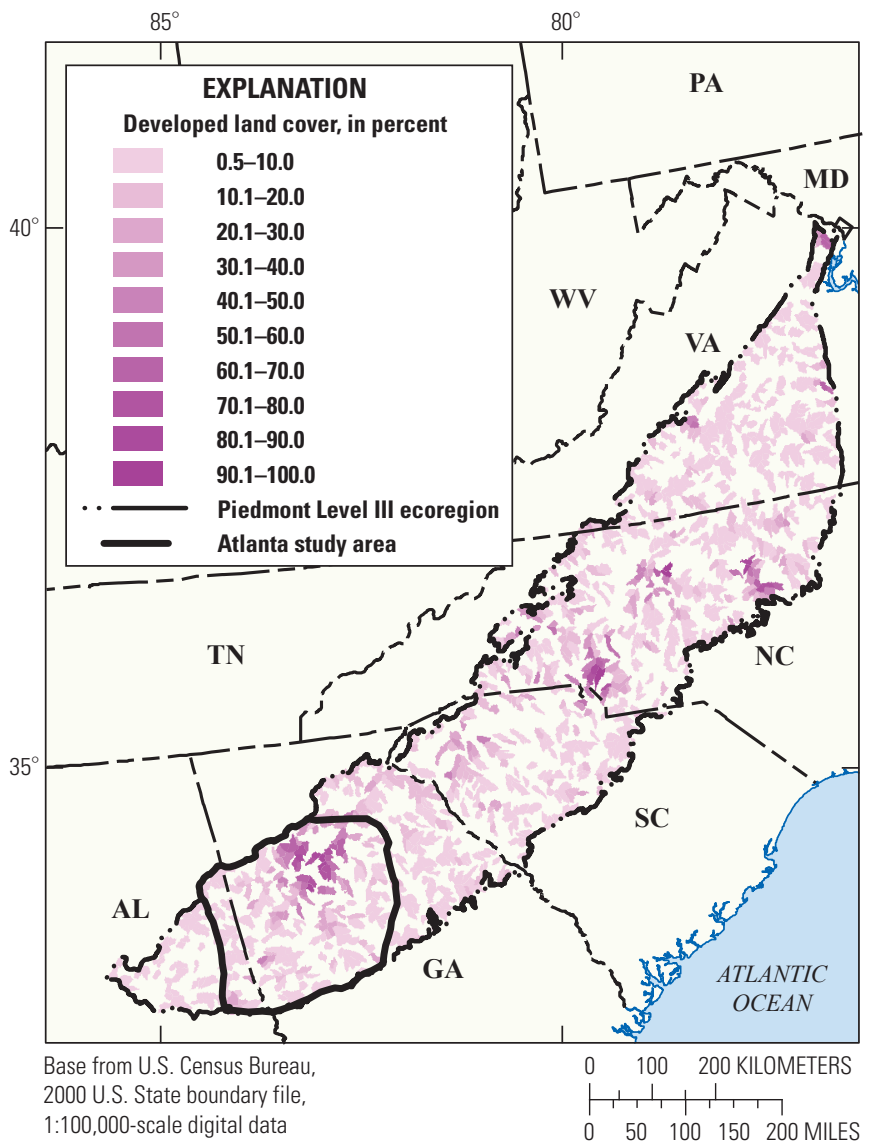

$\boldsymbol{F}$

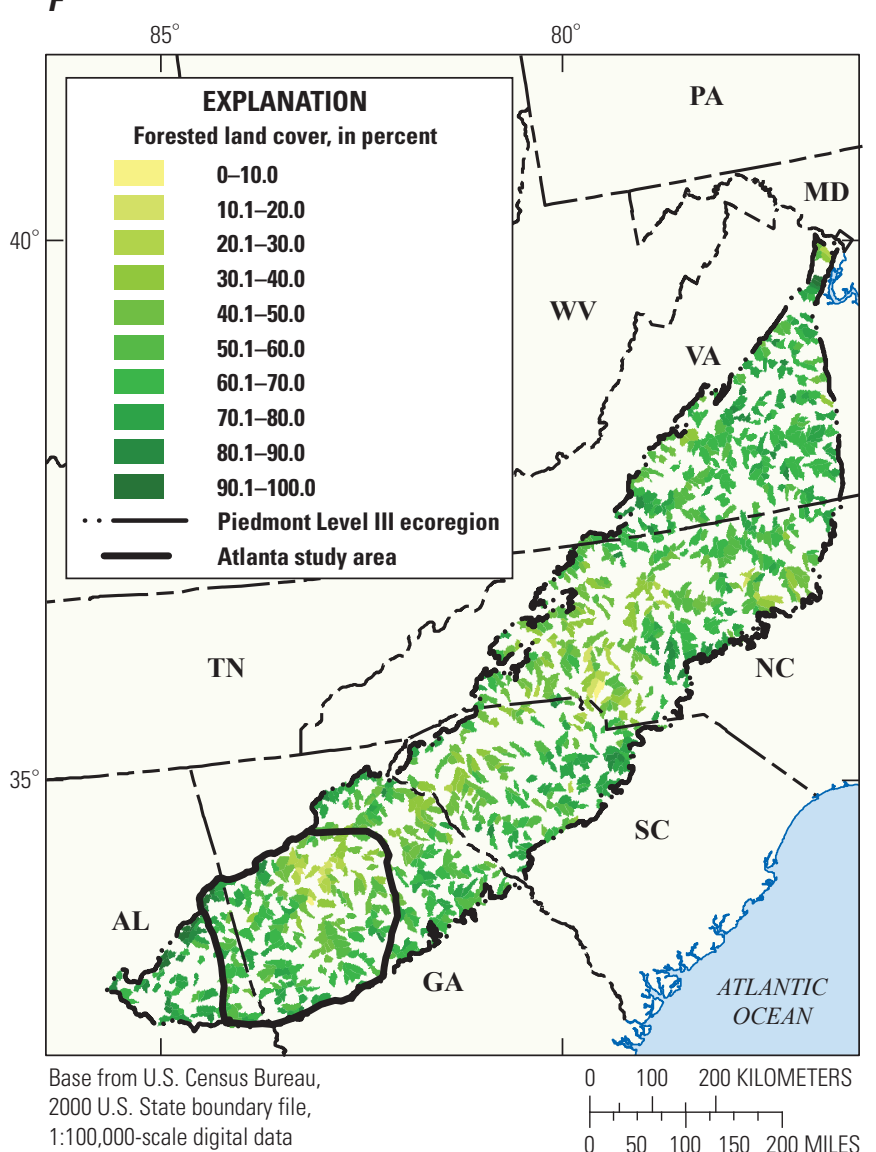

Figure 29-Continued. Summary of Piedmont Level III ecoregion watershed characteristics in the vicinity of Atlanta, including $(A)$ average annual temperature, $(B)$ average annual precipitation, $(C)$ elevation, $(D)$ average slope, $(E)$ developed land cover, $(F)$ forested land cover, and $(G)$ agricultural land cover. 


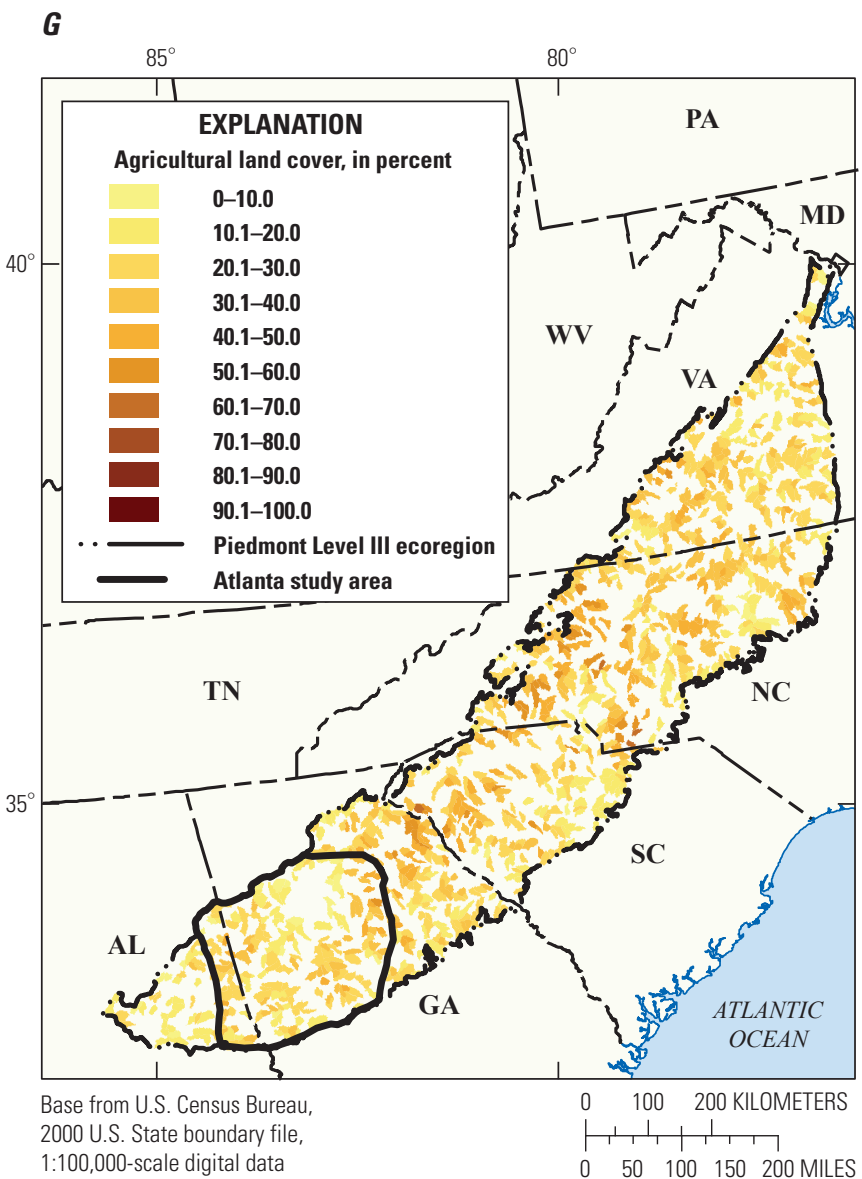

Figure 29-Continued. Summary of Piedmont Level III ecoregion watershed characteristics in the vicinity of Atlanta, including $(A)$ average annual temperature, $(B)$ average annual precipitation, $(C)$ elevation, $(D)$ average slope, $(E)$ developed land cover, $(F)$ forested land cover, and $(G)$ agricultural land cover. 

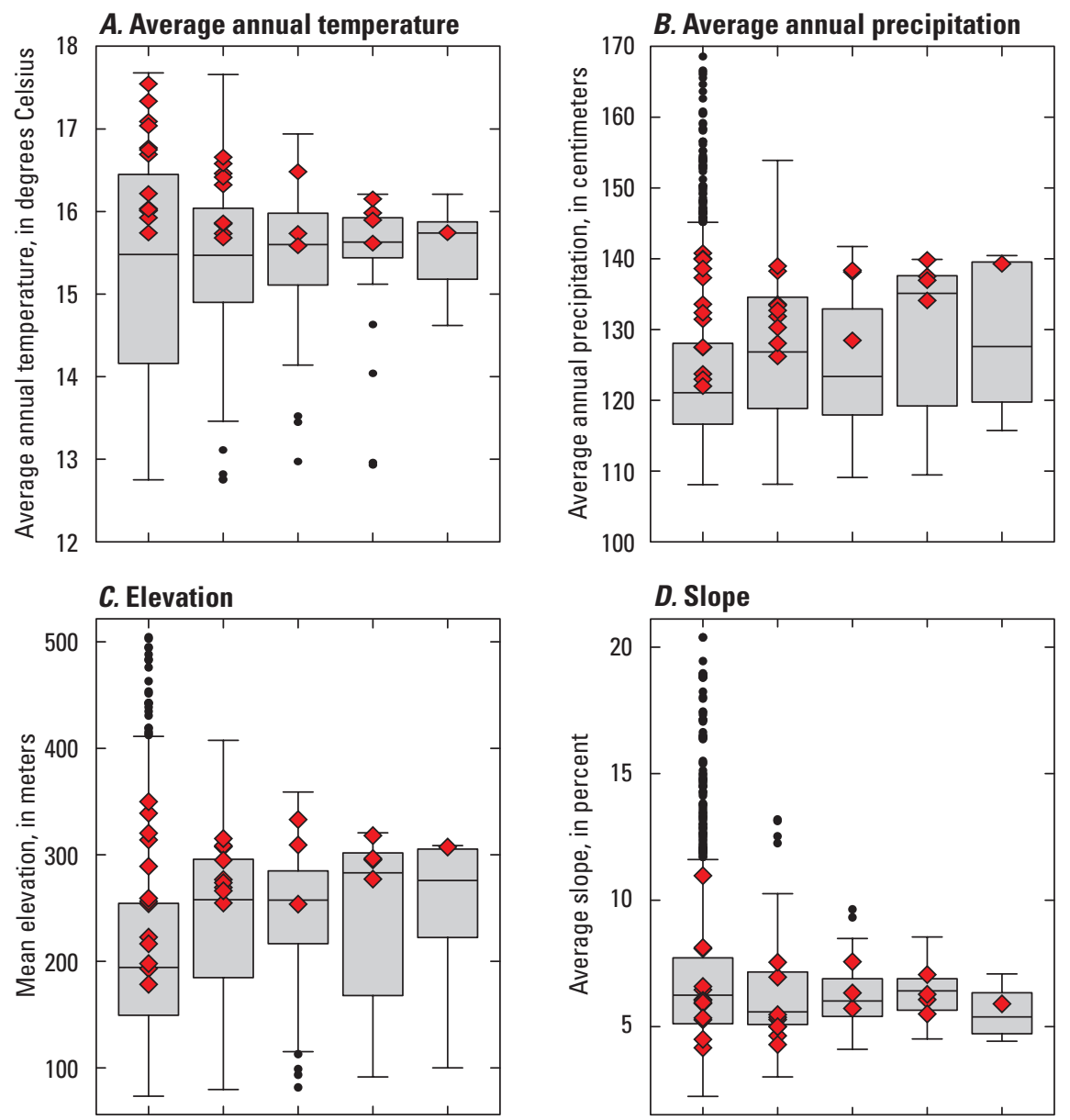

\section{EXPLANATION}

- Outlier

1.5 times the interquartile range

T above the box $\left.\begin{array}{|l|l}\hline & \begin{array}{l}75^{\text {th }} \text { percentile } \\ \text { Median } \\ \hline\end{array} \\ 25^{\text {th }} \text { percentile }\end{array}\right] \begin{gathered}\text { Interquartile } \\ \text { range }\end{gathered}$

1.5 times the interquartile range below the box

$\diamond \quad$ EUSE values within development class
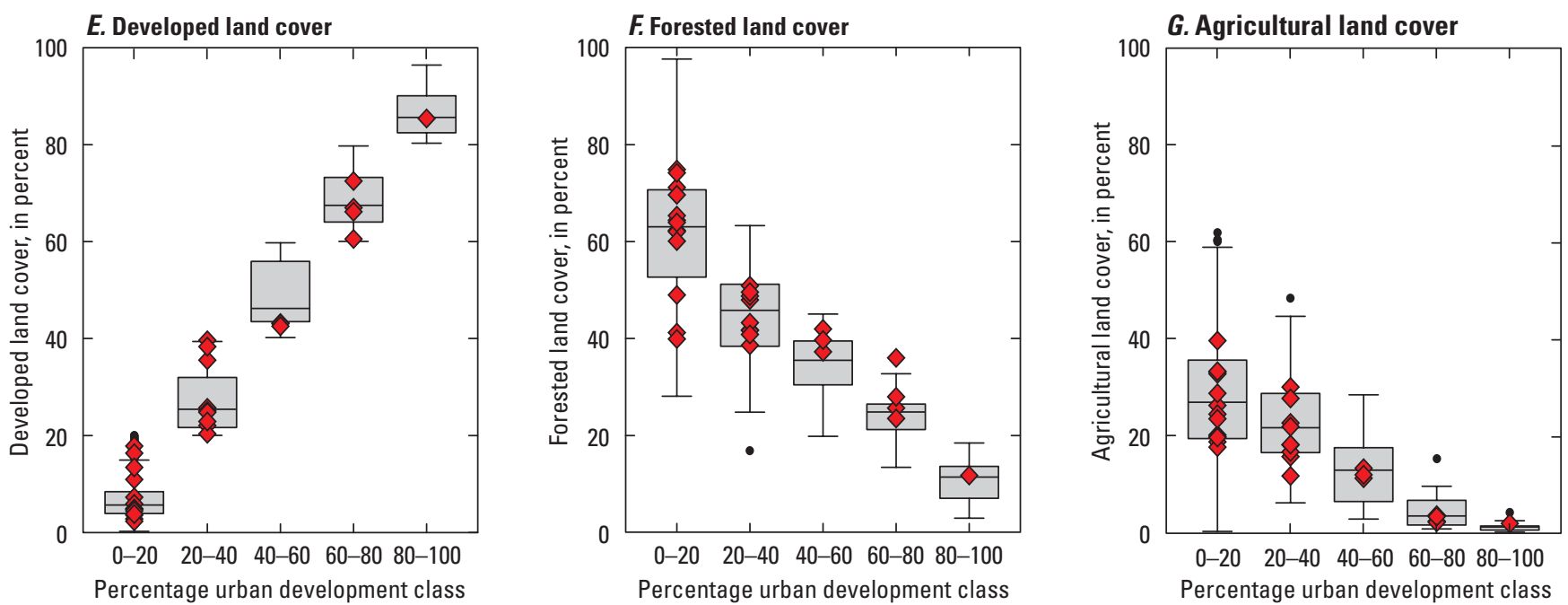

Figure 30. Summary of Piedmont Level III ecoregion and Atlanta EUSE study watershed characteristics by percentage of urban development class. $A$, Average annual temperature. $B$, Average annual precipitation. $C$, Mean elevation. $D$, Average slope. $E$, Developed land cover. F, Forested land cover. G, Agricultural land cover. 


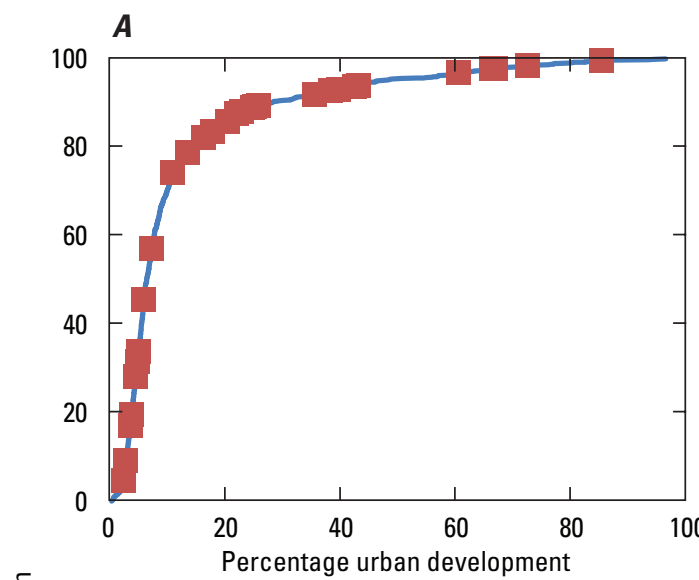

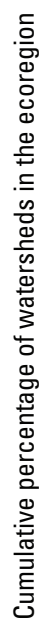

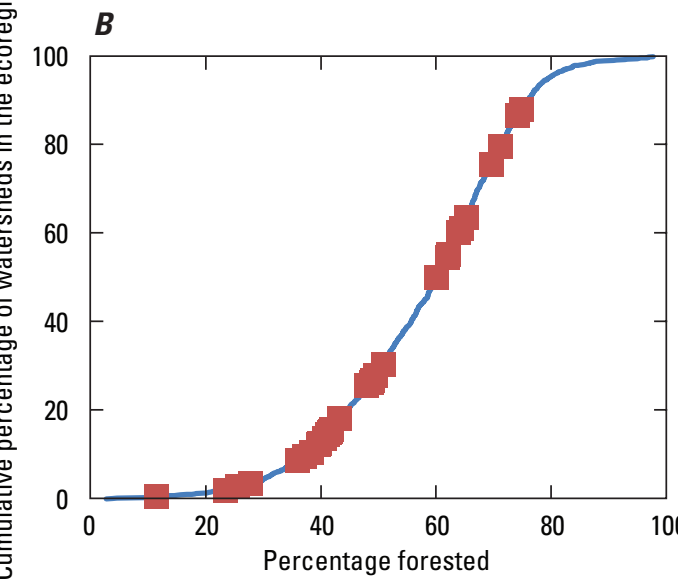

EXPLANATION

Distribution of land-cover characteristics within ecoregion watersheds

EUSE study watersheds

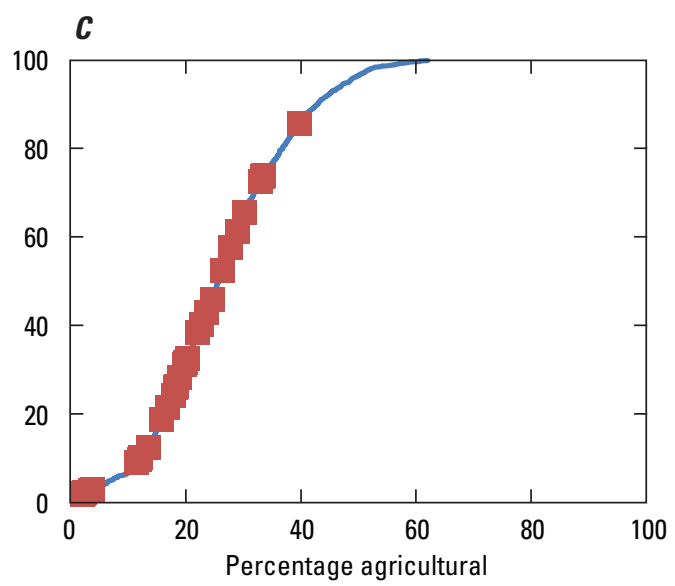

Figure 31. Cumulative distribution plot (blue line) of the percentage of $(A)$ urban development, $(B)$ forested, and $(C)$ agricultural land cover in the Piedmont Level III ecoregion watersheds, and the percentage of the same land-cover types in the Atlanta EUSE study watersheds. 


\section{Raleigh}

The Raleigh, North Carolina, EUSE study area consists of 30 watersheds that are within the Piedmont Level III ecoregion (app. 1). Soils vary from fine to moderately fine textures in the coastal plain and piedmont areas (McMahon and Lloyd, 1995). The climate is warm and humid with rainfall evenly distributed throughout the year. Streams have low to moderate gradients and typically have gravel to cobble substrate.

The Raleigh study area includes five population centers-Raleigh-Cary, Greensboro-High Point, Durham, Winston-Salem, and Burlington, with a combined 2000 population of 2.4 million, an increase of about 28 percent from 1990 (U.S. Census Bureau, 2009). The economy of the study area is diversified and has grown substantially in recent decades, in part as a result of the "Research Triangle" of Raleigh-Durham-Chapel Hill, a successful corporate research area associated with three nearby universities (McKnight, 2004). Heavy industry, primarily textiles, tobacco, chemicals, and furniture, dominate in the western part of the study area near Winston-Salem and Greensboro. Land use in the area has undergone major transformations, from forests to agricultural lands, to forest again, and recently to urban and suburban uses. At one time, the region was heavily farmed in cotton, tobacco, corn, and wheat, and many areas underwent moderate to severe erosion of the silt/clay soils (Trimble, 1974). The peak of agriculture in North Carolina was in 1948 (Lambeth, 2006), at which time more than 19 million acres were farmland, which was about 61 percent of the land area in the State (Hurley, 1950). By 1982 the total acreage of agricultural land was less than 9 million acres, less than half of the 1950 total. Most of this loss was in the coastal plain and piedmont areas.

\section{Climate Variables}

The range in average annual temperatures in the Piedmont ecoregion watersheds is broader than in the Raleigh EUSE watersheds, and the ecoregion watersheds have a slightly higher median value (tables 3 , 5; figs. $32 A, B ; 33 A, B$; $34 A, B)$. The range in average annual precipitation in the Piedmont ecoregion watersheds is $64.3 \mathrm{~cm}$, much larger than the $10.4 \mathrm{~cm}$ range for the Raleigh EUSE watersheds, and is reflected in all development classes. The median average annual precipitation is similar for both sets of watersheds. The $\mathrm{K}-\mathrm{W}$ test does not show a significant difference in the ecoregion and EUSE watersheds for either of these climate variables.

\section{Topographic Variables}

The elevation and slopes within the Piedmont ecoregion vary greatly along an east to west transect (fig. $33 C, D$ ). The range in elevation of the Piedmont ecoregion watersheds is much greater than for the Raleigh EUSE watersheds, with a similar median value (figs. $32 C, D ; 34 C, D$ ). The percentage slopes of EUSE study watersheds are more homogenous than for the ecoregion as a whole, with a slightly lower median value. There is a significant difference between the ecoregion and EUSE watershed slope distributions, but the distributions of elevations were statistically similar.

\section{Land-Cover Variables}

The range of developed land values in the Raleigh EUSE watersheds includes the range of values that exists in the Piedmont ecoregion as a whole, a pattern similar to Atlanta (figs. 32E, 34E, 35A). The ecoregion has a lower median and $75^{\text {th }}$ percentile of developed land than the EUSE sites, indicating that there are relatively few ecoregion watersheds with more than 10 percent developed land. The range and median values of the forested and agricultural land-cover percentages are greater for the ecoregion watersheds than for the EUSE watersheds (figs. 32E; 35B, C). The land cover in the Piedmont ecoregion is predominantly forest, and the undeveloped land in the Raleigh EUSE watersheds is also predominantly forest. 

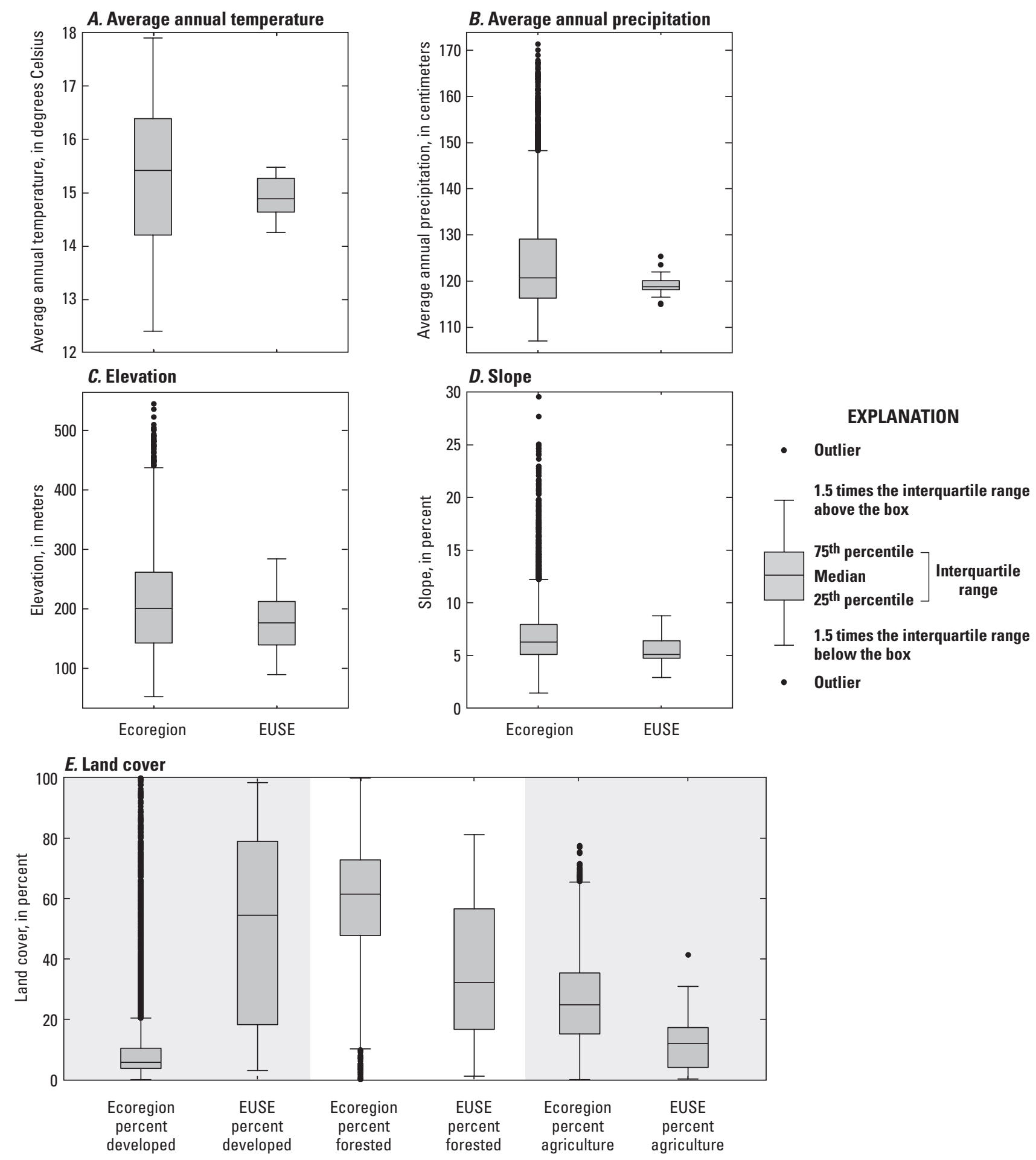

Figure 32. Summary of Piedmont Level III ecoregion and Raleigh EUSE study watershed characteristics, including $(A)$ average annual temperature, $(B)$ average annual precipitation, $(C)$ elevation, $(D)$ percent slope, and $(E)$ percent land cover. 
$\boldsymbol{A}$

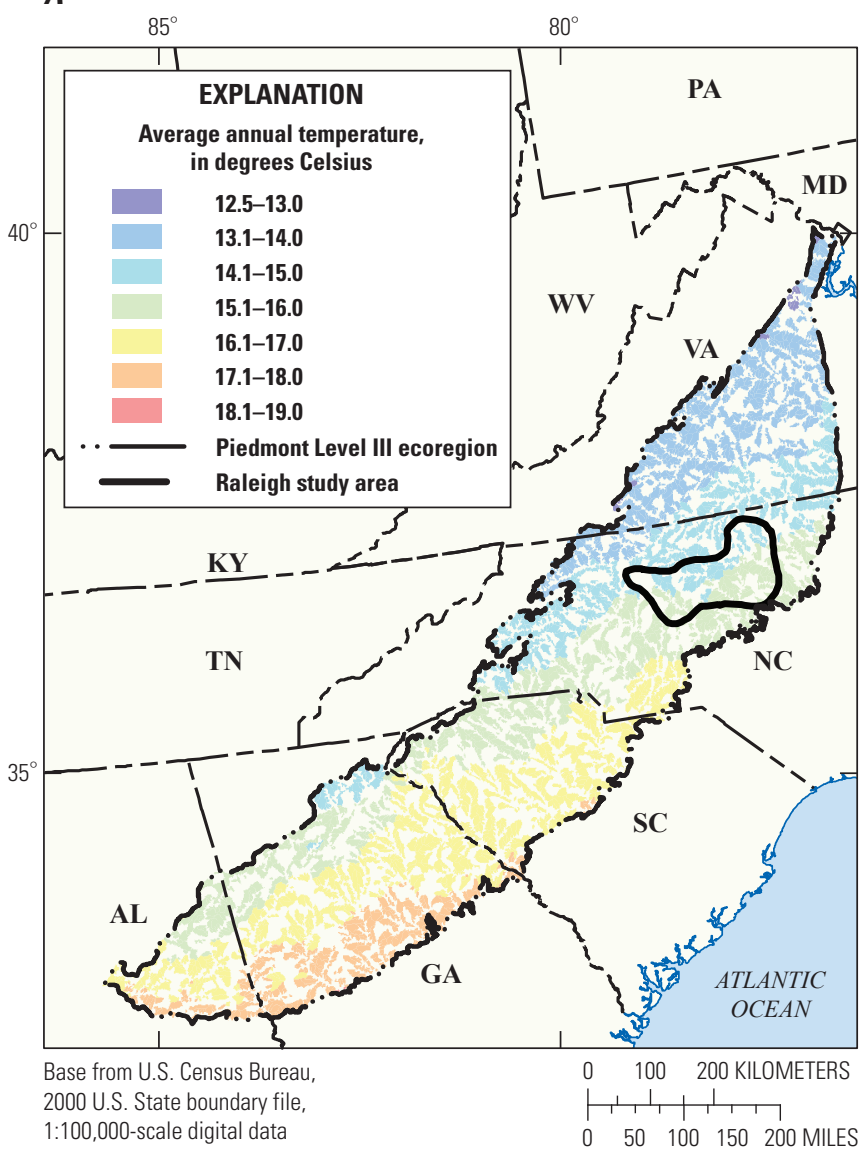

\section{$B$}

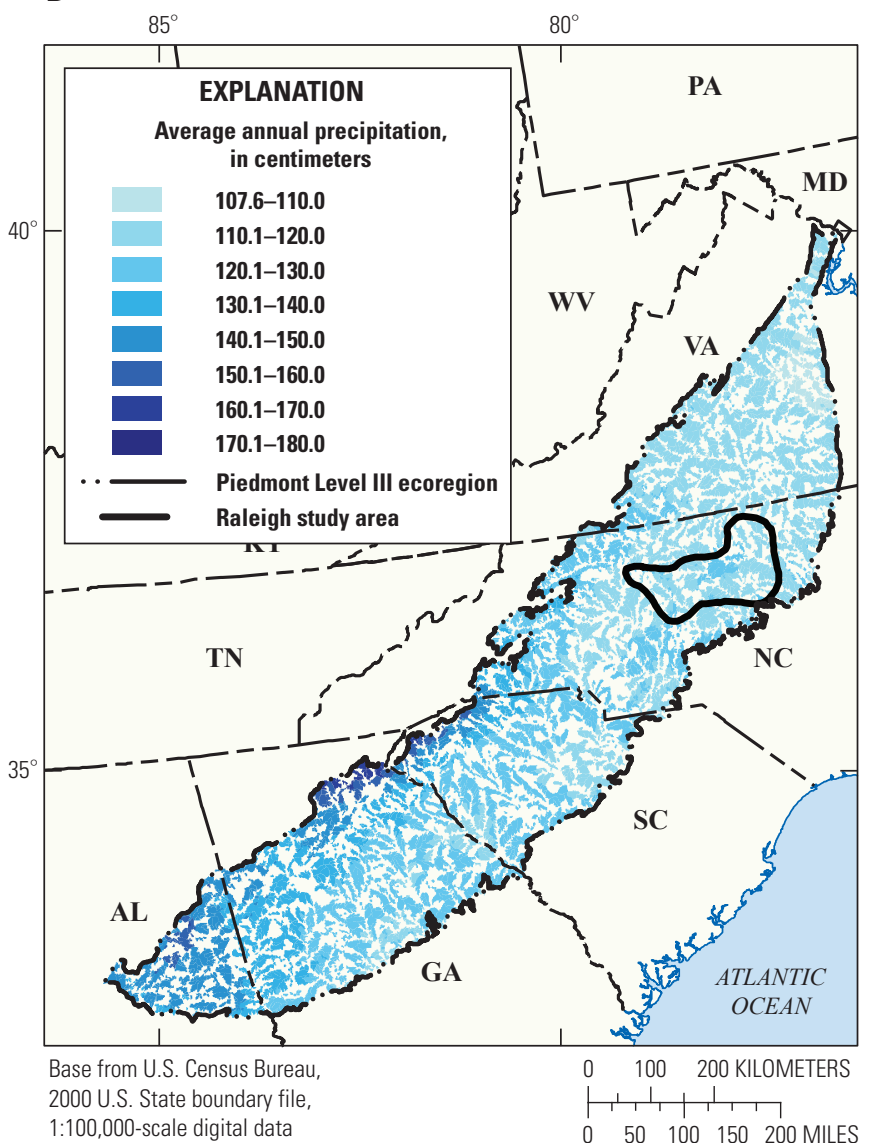

Figure 33. Summary of Piedmont Level III ecoregion watershed characteristics in the vicinity of Raleigh, including $(A)$ average annual temperature, $(B)$ average annual precipitation, $(C)$ elevation, $(D)$ average slope, $(E)$ developed land cover, $(F)$ forested land cover, and $(G)$ agricultural land cover. 
C

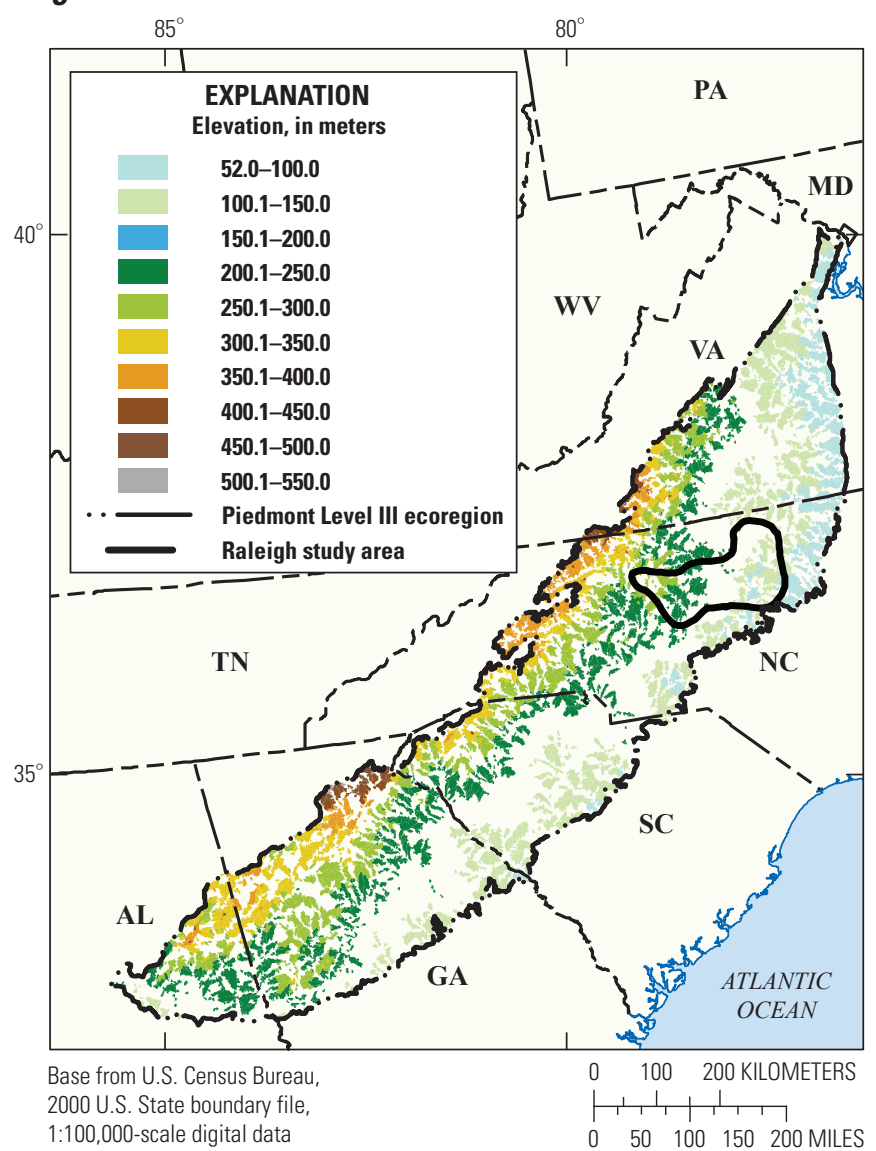

D

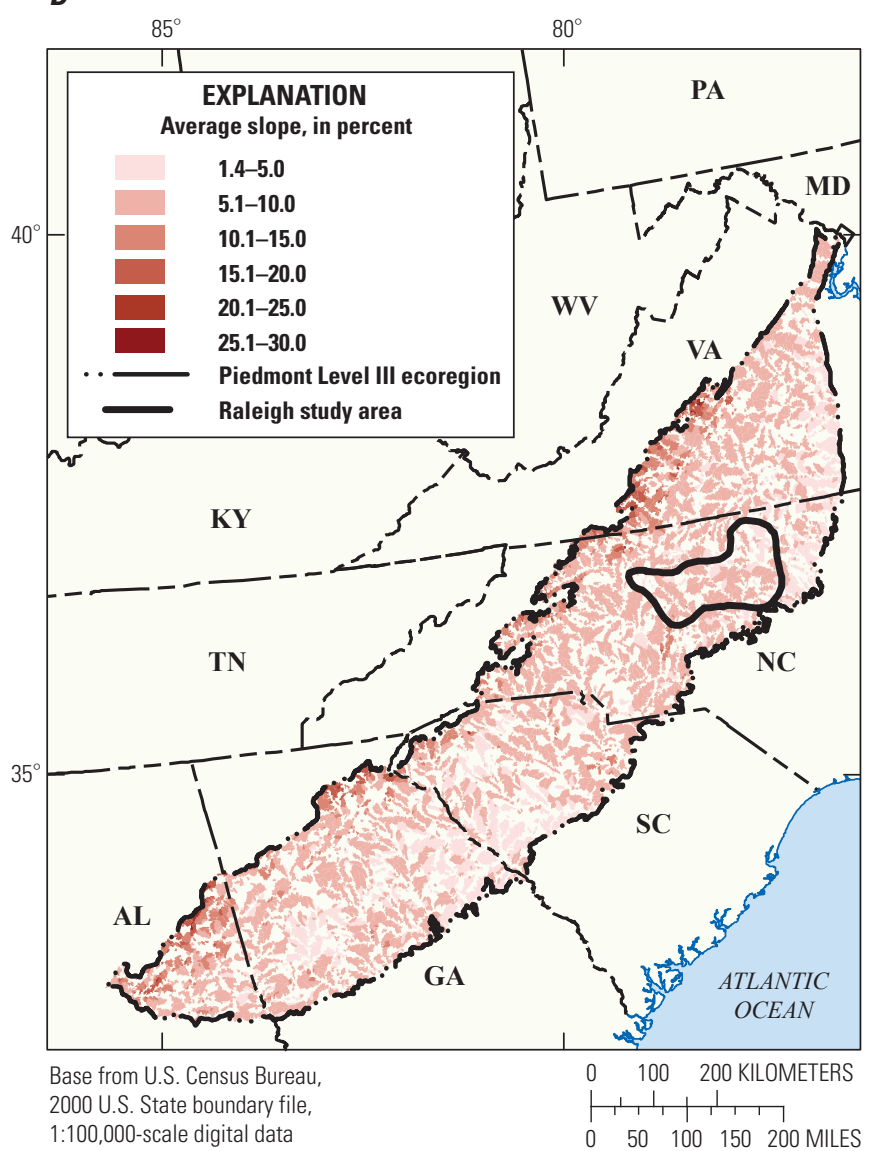

Figure 33-Continued. Summary of Piedmont Level III ecoregion watershed characteristics in the vicinity of Raleigh, including $(A)$ average annual temperature, $(B)$ average annual precipitation, $(C)$ elevation, $(D)$ average slope, $(E)$ developed land cover, $(F)$ forested land cover, and $(G)$ agricultural land cover. 
E

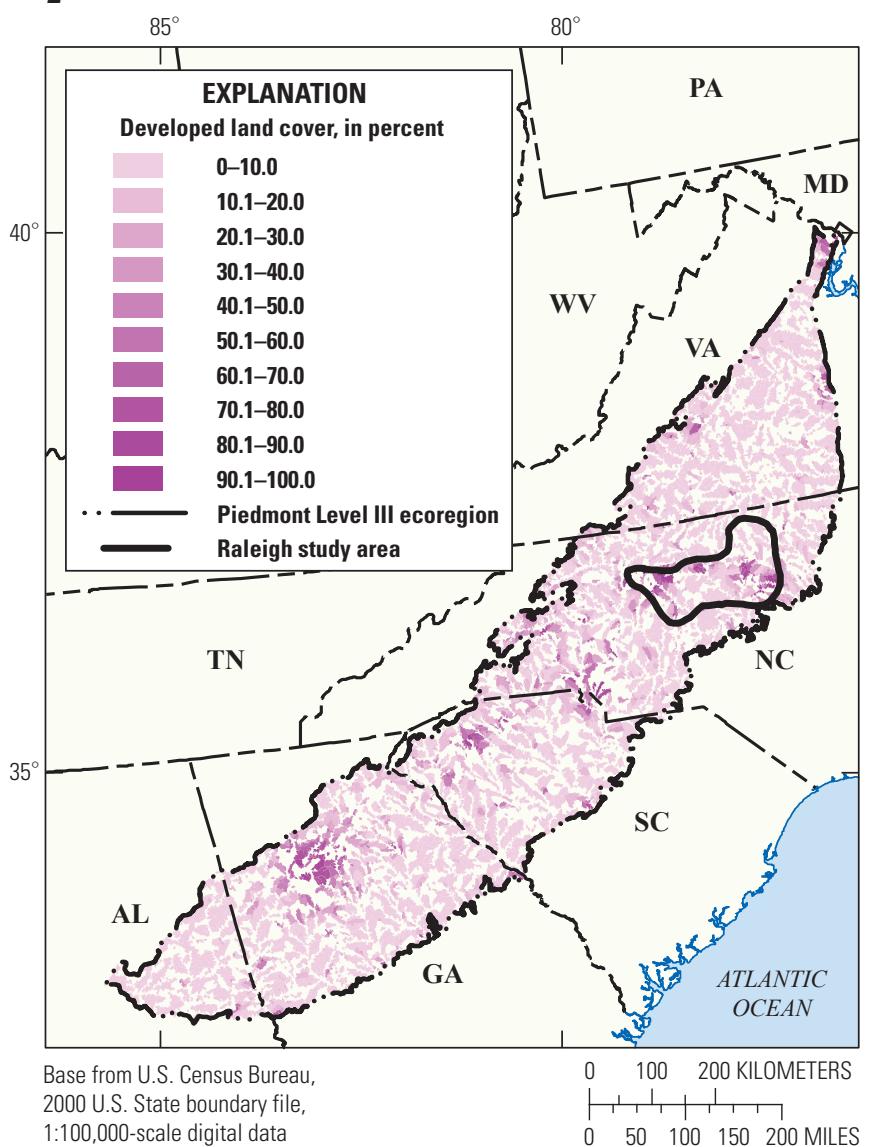

$\boldsymbol{F}$

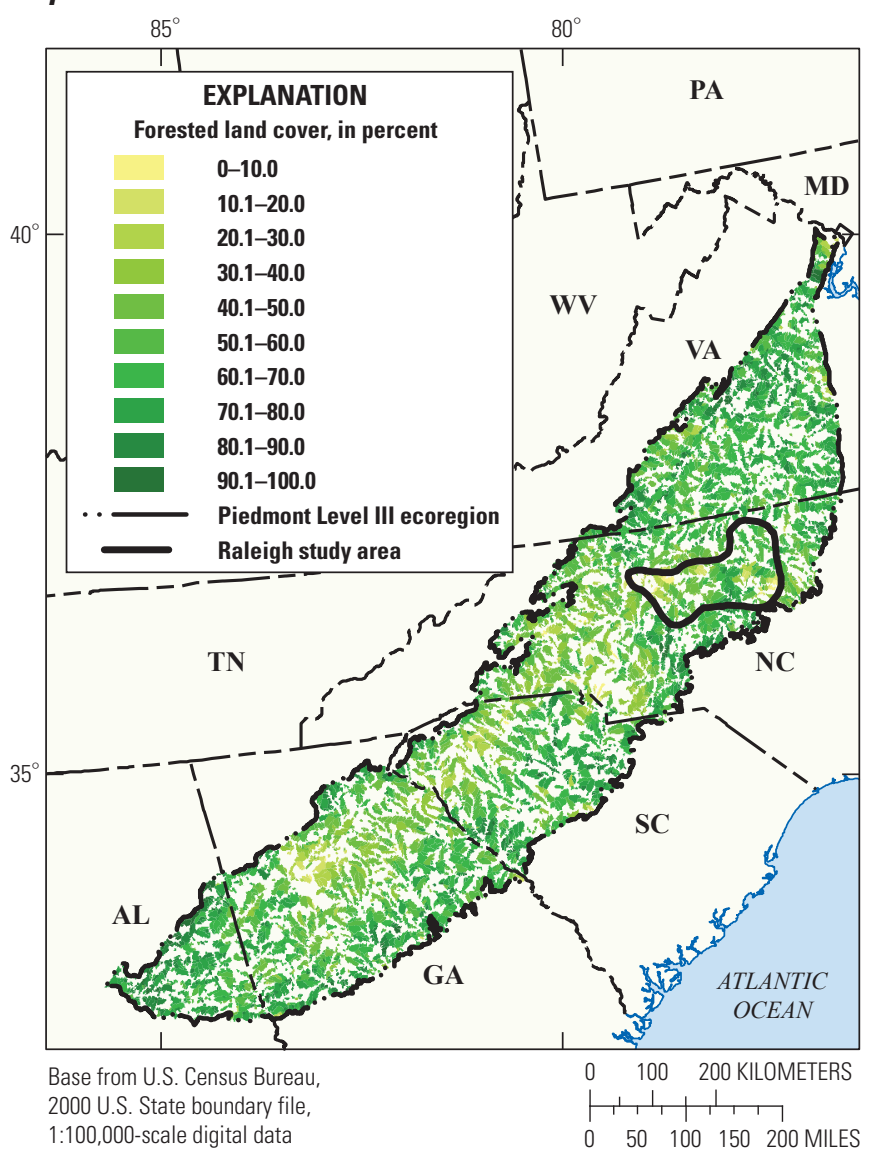

Figure 33-Continued. Summary of Piedmont Level III ecoregion watershed characteristics in the vicinity of Raleigh, including $(A)$ average annual temperature, $(B)$ average annual precipitation, $(C)$ elevation, $(D)$ average slope, $(E)$ developed land cover, $(F)$ forested land cover, and $(G)$ agricultural land cover. 


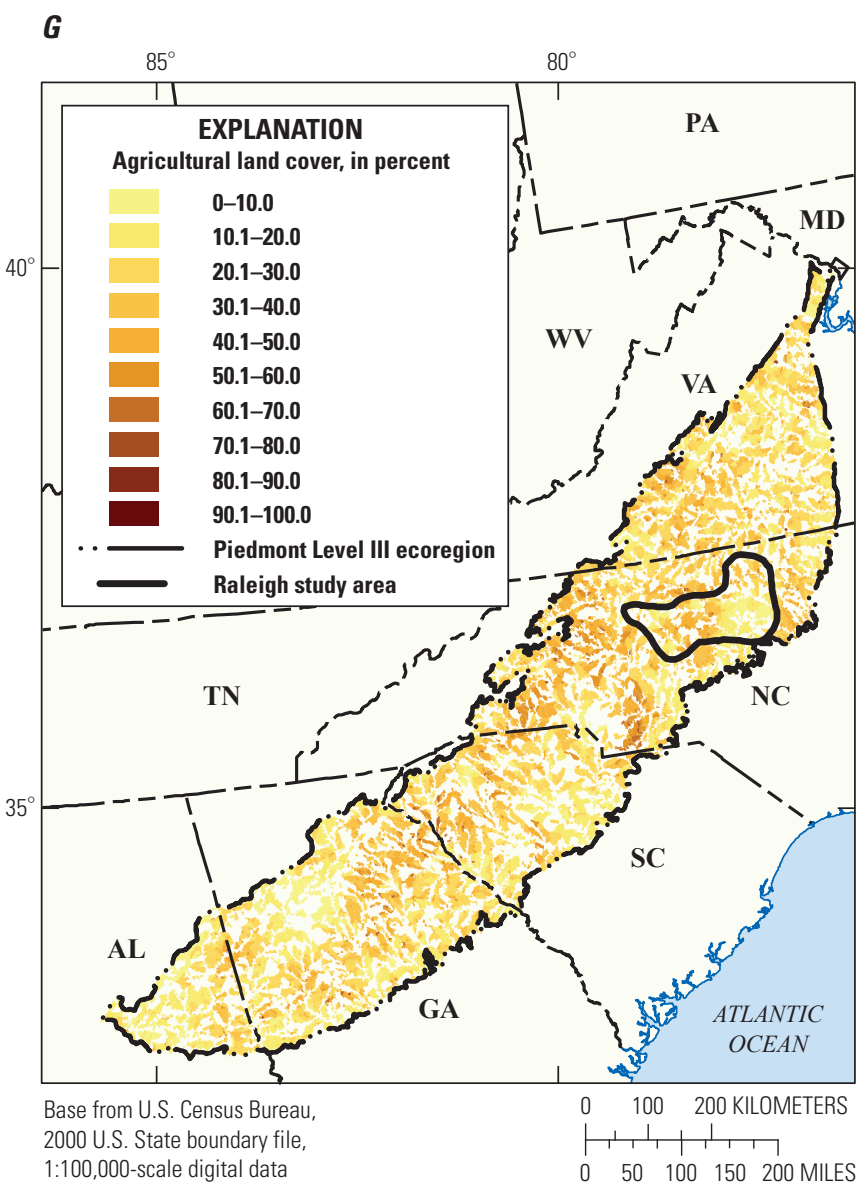

Figure 33-Continued. Summary of Piedmont Level III ecoregion watershed characteristics in the vicinity of Raleigh, including $(A)$ average annual temperature, $(B)$ average annual precipitation, $(C)$ elevation, $(D)$ average slope, $(E)$ developed land cover, $(F)$ forested land cover, and $(G)$ agricultural land cover. 
A. Average annual temperature
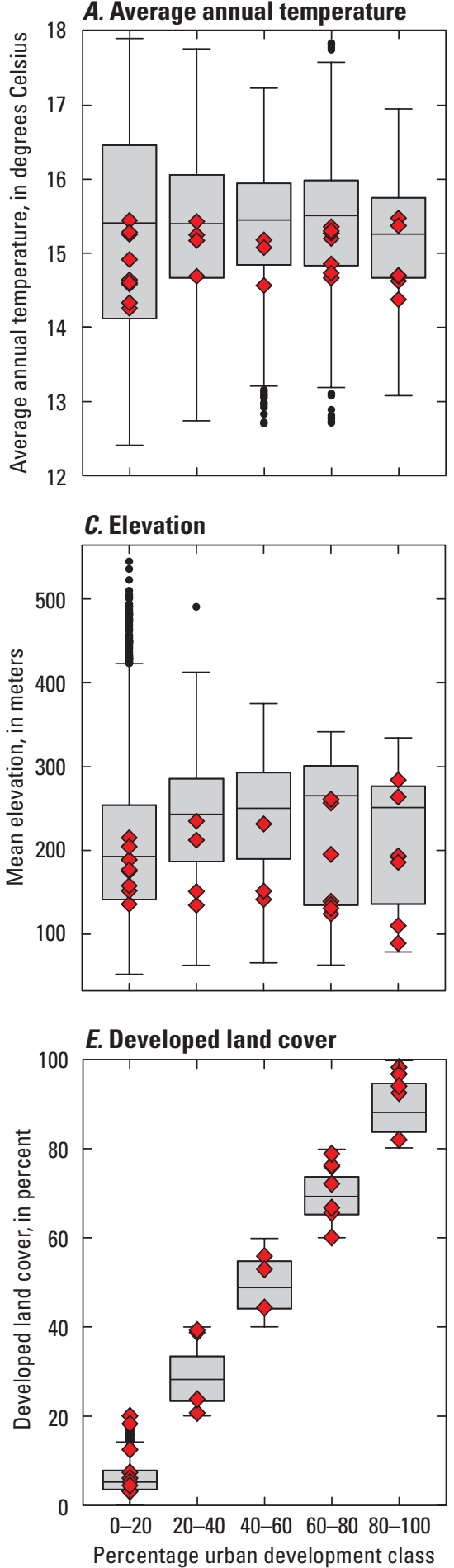

B. Average annual precipitation
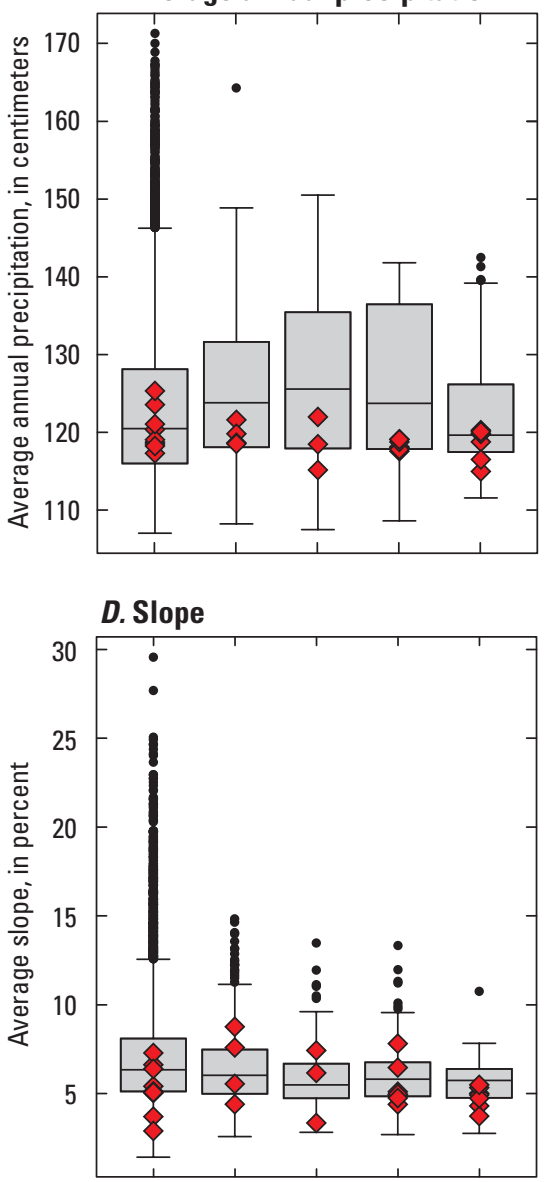

EXPLANATION

- Outlier

1.5 times the interquartile range above the box

$75^{\text {th }}$ percentile \begin{tabular}{c|c} 
Median & $\begin{array}{c}\text { Interquartile } \\
\text { range }\end{array}$
\end{tabular} $25^{\text {th }}$ percentile range

1.5 times the interquartile range below the box

$\diamond \quad$ EUSE values within development class

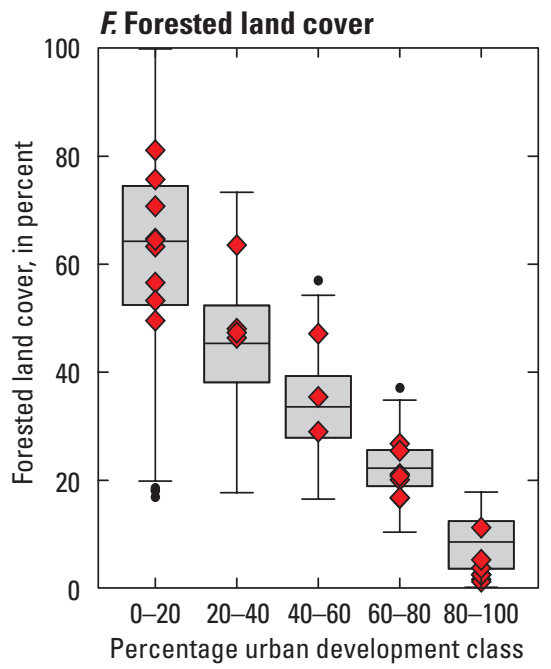

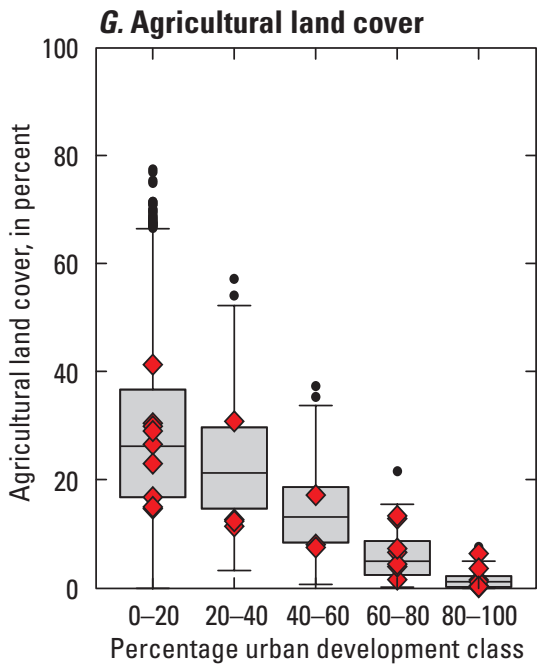

Figure 34. Summary of Piedmont Level III ecoregion and Raleigh EUSE study watershed characteristics by percentage of urban development class. $A$, Average annual temperature. $B$, Average annual precipitation. $C$, Mean elevation. $D$, Average slope. $E$, Developed land cover. F, Forested land cover. G, Agricultural land cover. 

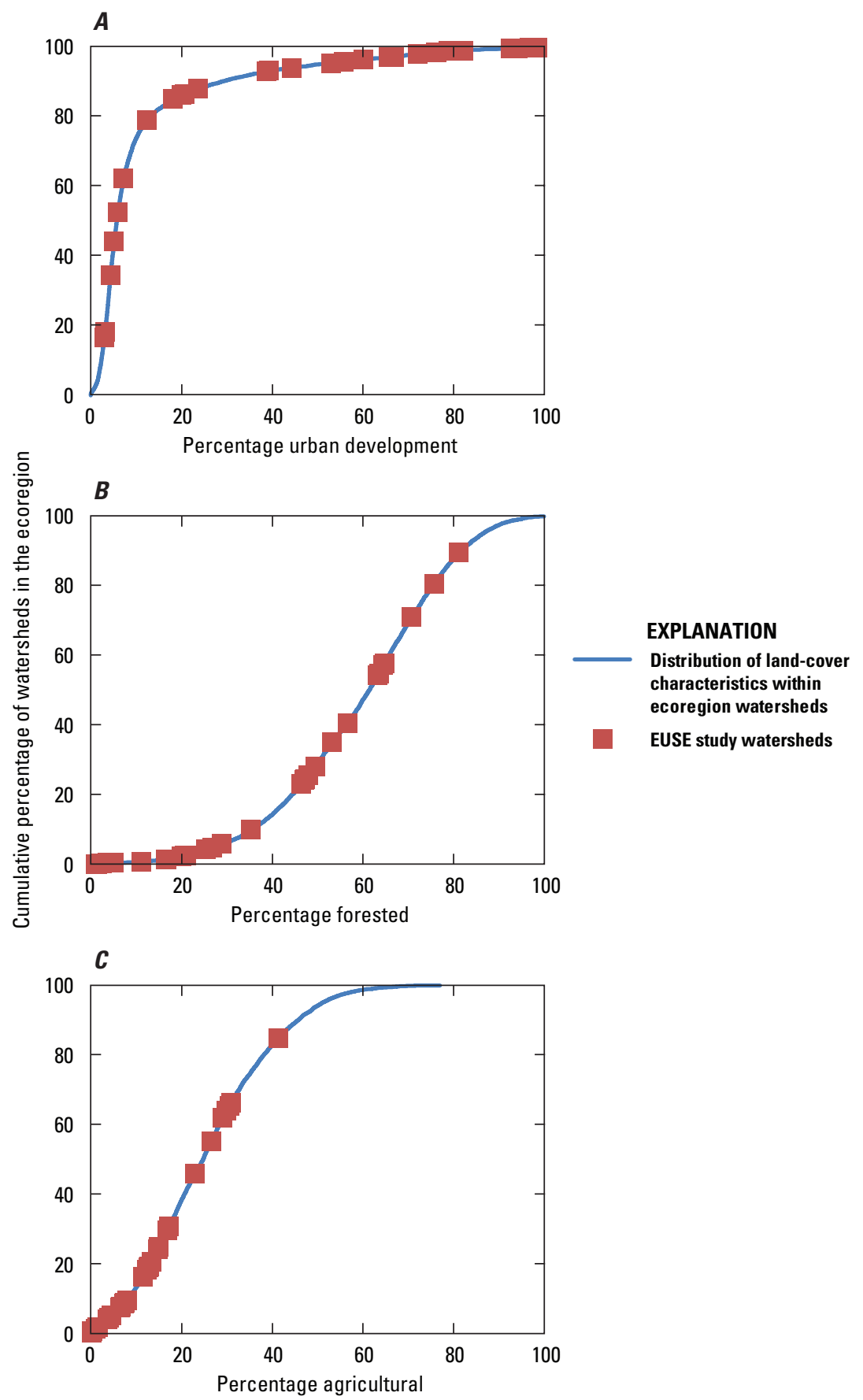

Figure 35. Cumulative distribution plot (blue line) of the percentage of $(A)$ urban development, $(B)$ forested, and $(C)$ agricultural land cover in the Piedmont Level III ecoregion watersheds, and the percentage of the same land-cover types in the Raleigh EUSE study watersheds. 


\section{Boston}

The 30 Boston, Massachusetts, EUSE study watersheds include portions of Massachusetts, New Hampshire, Maine, and Connecticut and are located within the Northeastern Coastal Zone Level III ecoregion (app. 1). The area is characterized by moderately coarse to coarse textured soils, low hills, forests, cropland and pasture, and urban lands (Flanagan and others, 1999; Giddings and others, 2009). The climate is cool and humid, and the area experiences frost periods and snow in winter months, although precipitation is evenly distributed throughout the year with slightly higher amounts in the spring and fall (Falcone and others, 2007).

The Boston study area includes portions of four cities, including Boston, Massachusetts; Worcester, Massachusetts; Concord, New Hampshire; and Manchester-Nashua, New Hampshire. The combined 2000 population for these cities, 5.7 million, increased by about 7 percent from 1990 (U.S. Census Bureau, 2009). The land cover currently (2011) is composed of a mix of forest, urban, and agriculture. The area was first colonized and developed in the early to mid-1600s by immigrants from England for its location as a port on the Atlantic Ocean. The natural land cover was mixed forest but was cleared for lumber materials, and the land was converted to agricultural uses (Flanagan and others, 1999). The area was allowed to revert back to forests as the industrial revolution encouraged families to abandon the farms for jobs in the cities (Flanagan and others, 1999). Many factories and mills were built along rivers, so that more than 1,600 dams in the area regulate flows in the watershed with drainage areas exceeding 250 square kilometers $\left(\mathrm{km}^{2}\right.$; Flanagan and others, 1999).

\section{Climate Variables}

The average annual temperature and precipitation ranges for the Northeastern Coastal Zone ecoregion are broad, given the small size of the ecoregion. For the Northeastern Coastal Zone ecoregion watersheds, the average annual temperature ranges from $7.2^{\circ} \mathrm{C}$ to $12^{\circ} \mathrm{C}$, and the average annual precipitation ranges from 98 to $139.6 \mathrm{~cm}$ (tables 3, 5; figs. 36A, $B$; $37 \mathrm{~A}, B ; 38 A, B)$. The Boston EUSE study watersheds have a lower median average annual temperature, with the maximum value lower than the 75th percentile value of the ecoregion range. The ecoregion watersheds with $80-100$ percent development have the highest mean annual temperature, but no EUSE watersheds are in this development category. The median average annual precipitation is similar in both sets of watersheds, but the Boston EUSE watersheds have a narrower range. The K-W test indicates that the ecoregion and EUSE watersheds do not have significantly different average annual precipitation distributions.

\section{Topographic Variables}

The median elevation of the Boston EUSE watersheds is slightly higher and the range is smaller than that of the Northeastern Coastal Zone ecoregion watersheds (fig. 36C, D). Median slopes of the EUSE watersheds are also similar to those of the ecoregion watersheds, but the EUSE watersheds have a smaller range of values. The $\mathrm{K}-\mathrm{W}$ test results indicate that the ecoregion and EUSE watersheds have the same distribution of values for the two topographic variables.

\section{Land-Cover Variables}

The range of developed land percentages in the Boston EUSE watersheds encompasses the range of values for the Northeastern Coastal Zone ecoregion watersheds (figs. 36E, $38 E, 39 A)$. The most notable omission is for EUSE watersheds within the highest development category; no watersheds were sampled that were more than 80 percent developed. The ecoregion has a higher median and $75^{\text {th }}$ percentile of developed land than the EUSE sites. The range and median values of the forested land-cover percentage are greater for the ecoregion watersheds than for the EUSE watersheds (figs. 36E, 39B). The land cover in the Northeastern Coastal Zone ecoregion is predominantly forest, and the undeveloped land in the Boston EUSE watersheds is also predominantly forest. Values of the ecoregion and EUSE watershed land-cover variables do not have statistically different distributions. 

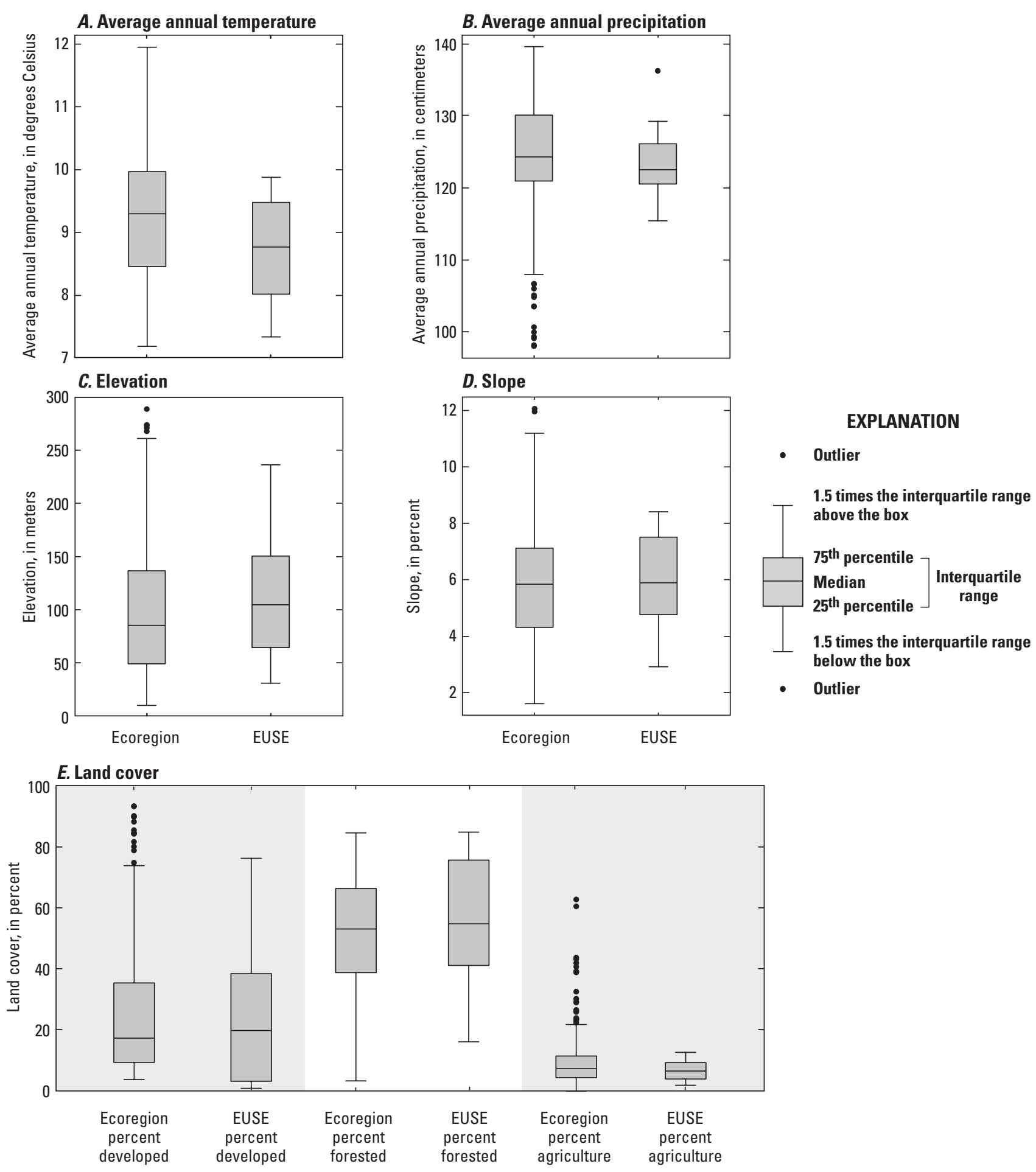

Figure 36. Summary of Northeastern Coastal Zone Level III ecoregion and Boston EUSE study watershed characteristics, including $(A)$ average annual temperature, $(B)$ average annual precipitation, $(C)$ elevation, $(D)$ percent slope, and $(E)$ percent land cover. 
A

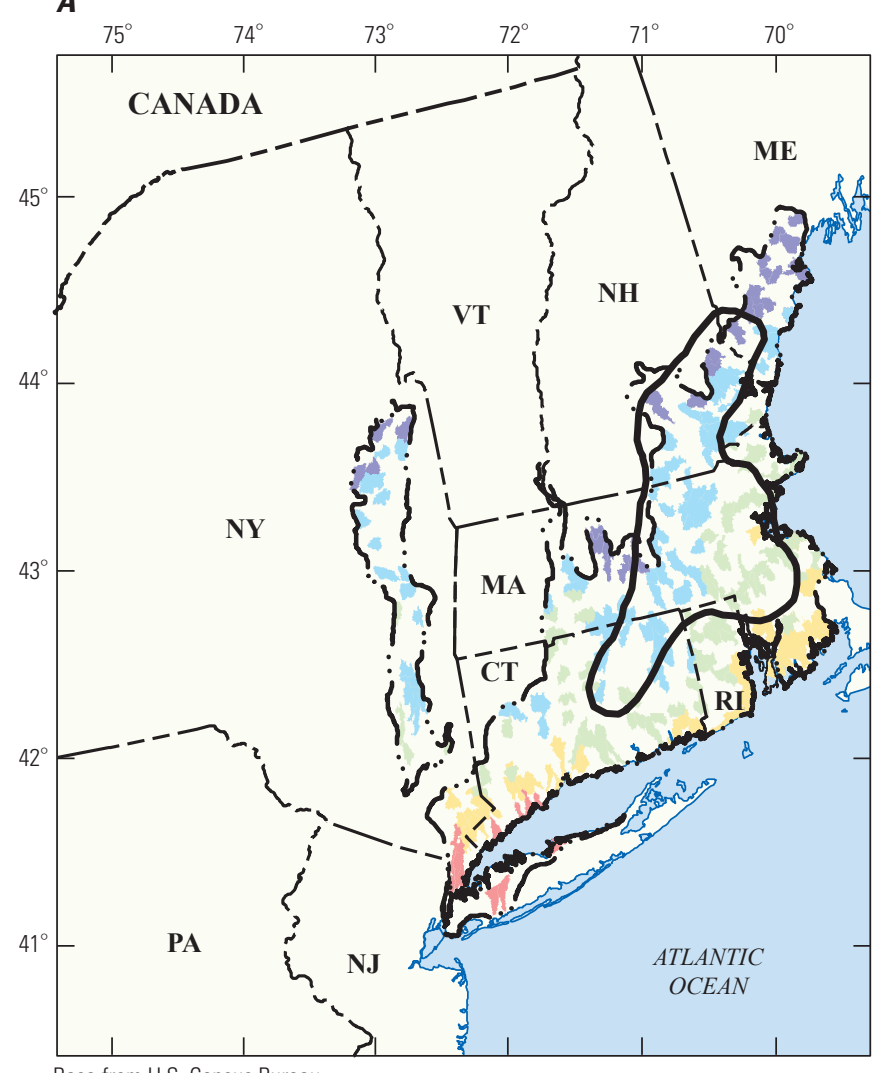

Base from U.S. Census Bureau,

2000 U.S. State boundary file,

1:100,000-scale digital data

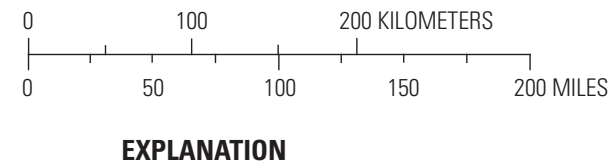

Average annual temperature, in degrees Celsius

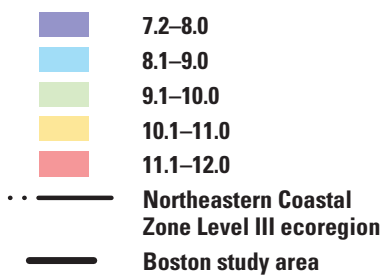

B

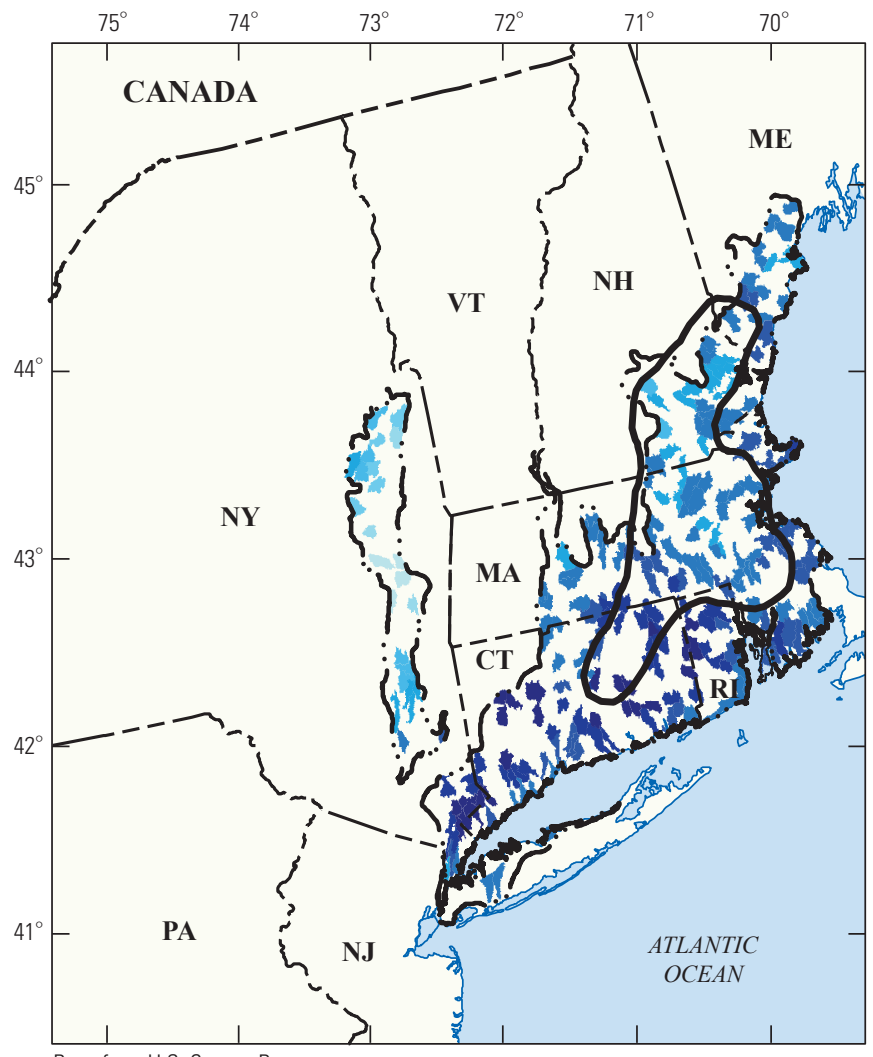

Base from U.S. Census Bureau, 2000 U.S. State boundary file,

1:100,000-scale digital data

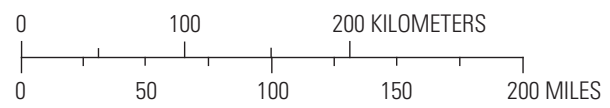

EXPLANATION

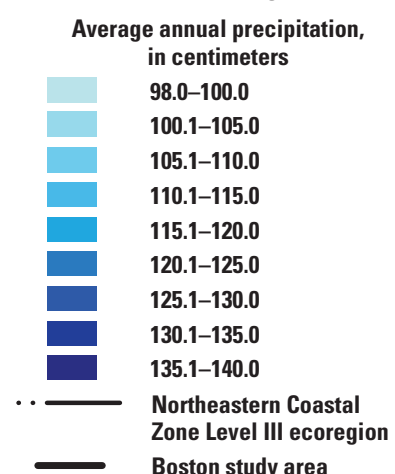

Figure 37. Summary of Northeastern Coastal Zone Level III ecoregion watershed characteristics, including $(A)$ average annual temperature, $(B)$ average annual precipitation, $(C)$ elevation, $(D)$ average slope, $(E)$ developed land cover, $(F)$ forested land cover, and $(G)$ agricultural land cover. 

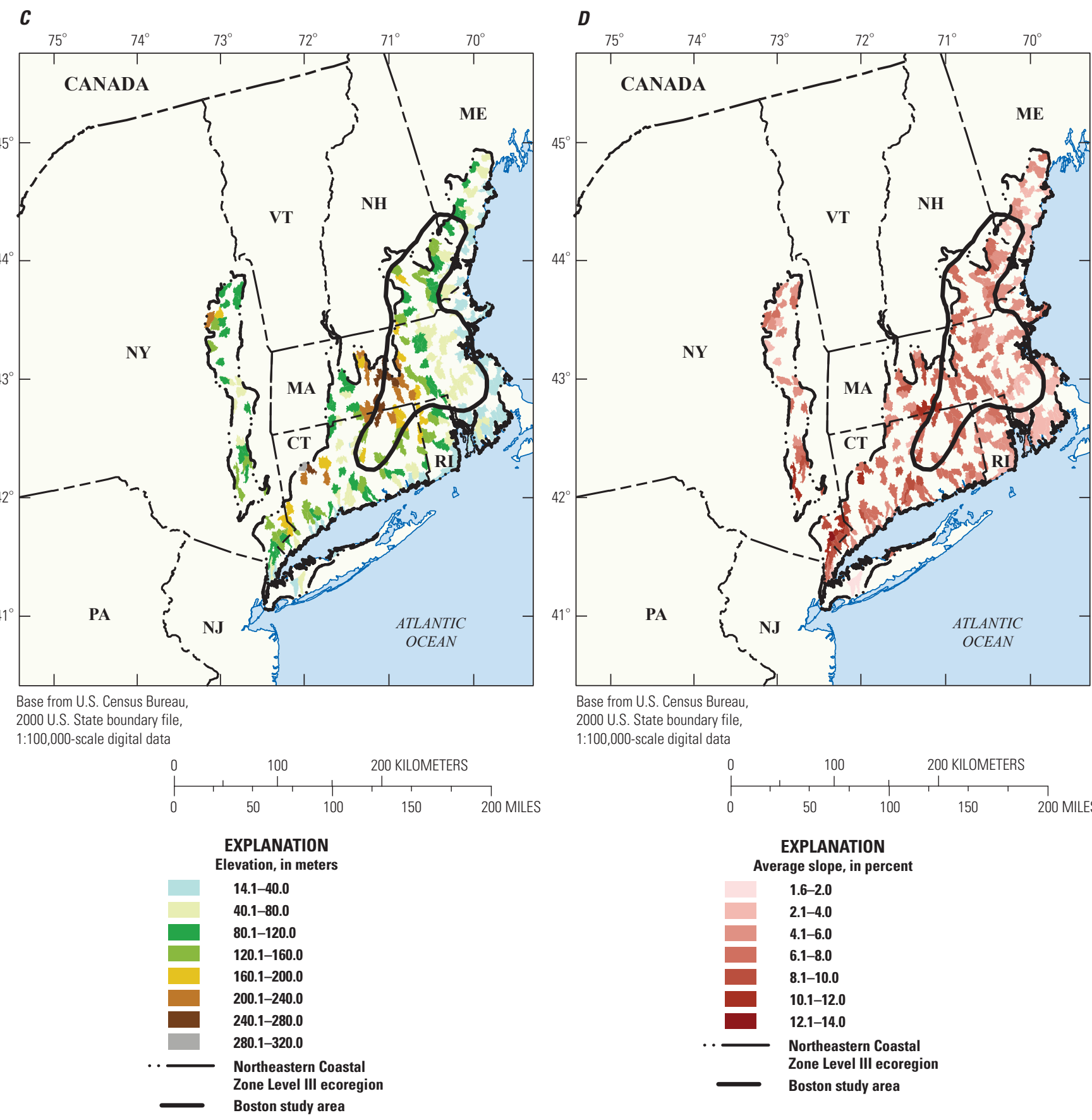

Base from U.S. Census Bureau

2000 U.S. State boundary file,

1:100,000-scale digital data

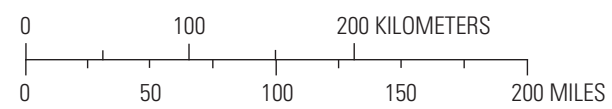

EXPLANATION

Average slope, in percent

1.6-2.0

2.1-4.0

4.1-6.0

6.1-8.0

8.1-10.0

$10.1-12.0$

12.1-14.0

Northeastern Coastal

Zone Level III ecoregion

Boston study area

Figure 37-Continued. Summary of Northeastern Coastal Zone Level III ecoregion watershed characteristics, including $(A)$ average annual temperature, $(B)$ average annual precipitation, $(C)$ elevation, $(D)$ average slope, $(E)$ developed land cover, $(F)$ forested land cover, and $(G)$ agricultural land cover. 
$\boldsymbol{E}$

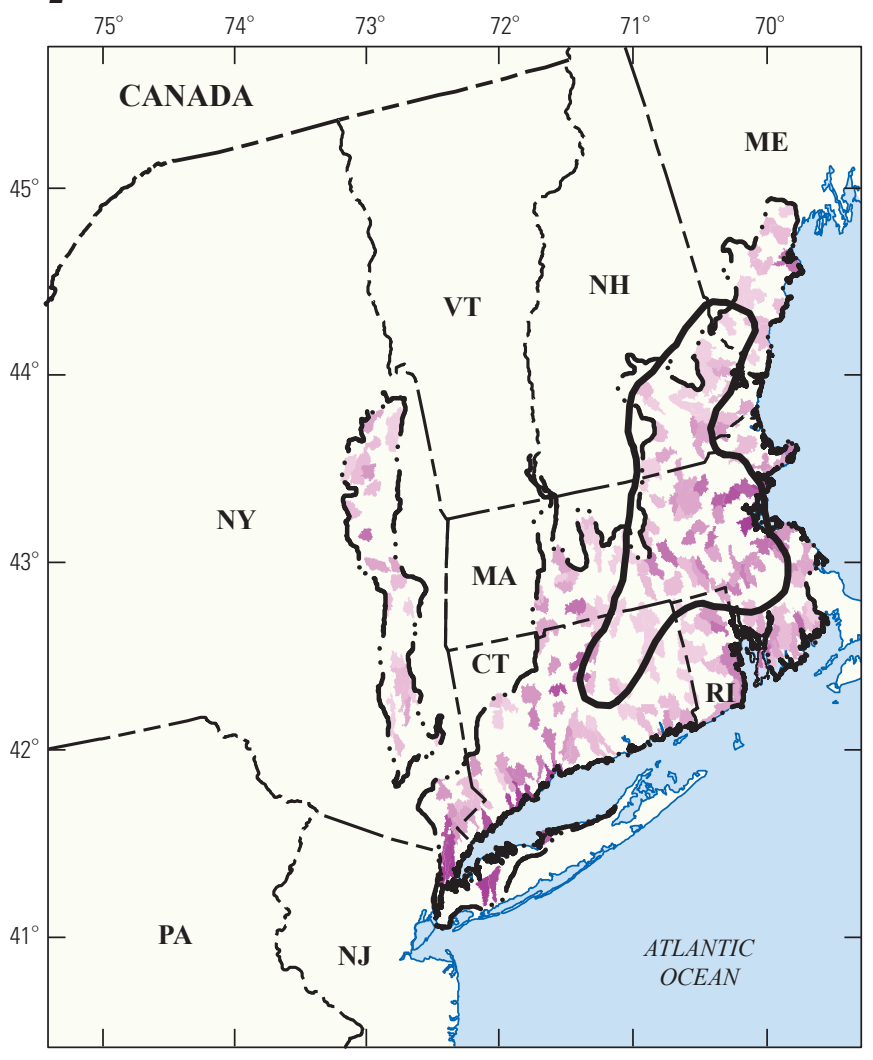

$\boldsymbol{F}$

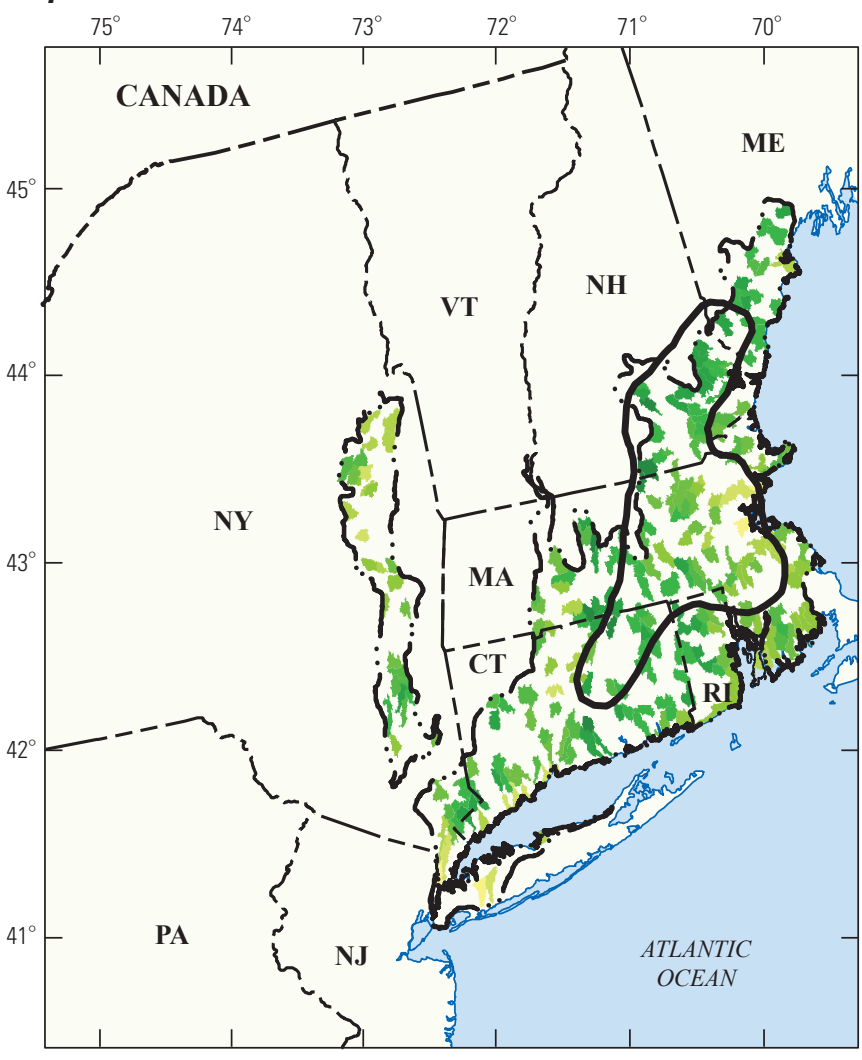

Base from U.S. Census Bureau

2000 U.S. State boundary file,

Base from U.S. Census Bureau,

2000 U.S. State boundary file,

1:100,000-scale digital data
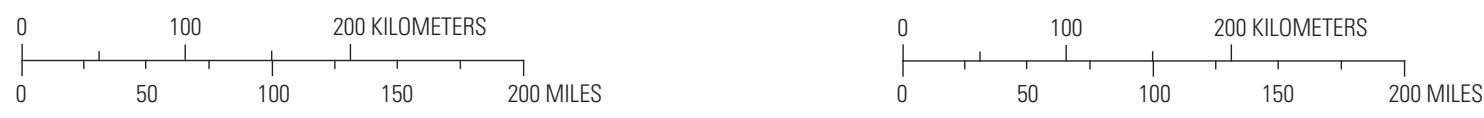

EXPLANATION

EXPLANATION

Developed land cover, in percent

0.5-10.0

$10.1-20.0$

20.1-30.0

$30.1-40.0$

40.1-50.0

$50.1-60.0$

60.1-70.0

70.1-80.0

80.1-90.0

90.1-100.0

Northeastern Coastal

Zone Level III ecoregion

ted land cover, in percent

Forested land
$\mathbf{0}-\mathbf{1 0 . 0}$

$10.1-20.0$

20.1-30.0

$30.1-40.0$

40.1-50.0

50.1-60.0

$60.1-70.0$

70.1-80.0

80.1-90.0

90.1-100.0

Northeastern Coastal

Zone Level III ecoregion

Boston study area

Boston study area

Figure 37-Continued. Summary of Northeastern Coastal Zone Level III ecoregion watershed characteristics, including $(A)$ average annual temperature, $(B)$ average annual precipitation, $(C)$ elevation, $(D)$ average slope, $(E)$ developed land cover, $(F)$ forested land cover, and $(G)$ agricultural land cover. 


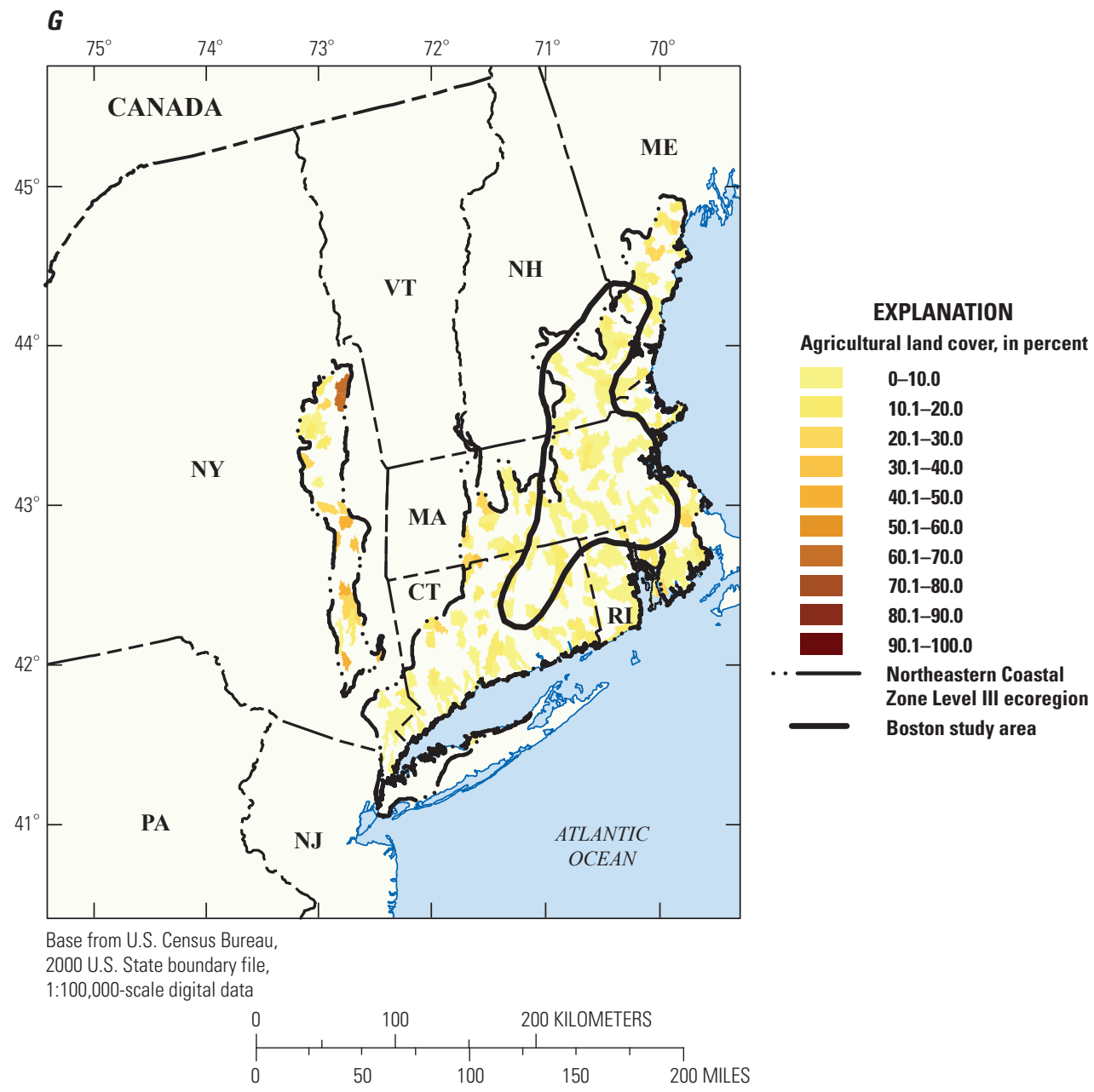

Figure 37-Continued. Summary of Northeastern Coastal Zone Level III ecoregion watershed characteristics, including $(A)$ average annual temperature, $(B)$ average annual precipitation, $(C)$ elevation, $(D)$ average slope, $(E)$ developed land cover, $(F)$ forested land cover, and $(G)$ agricultural land cover. 

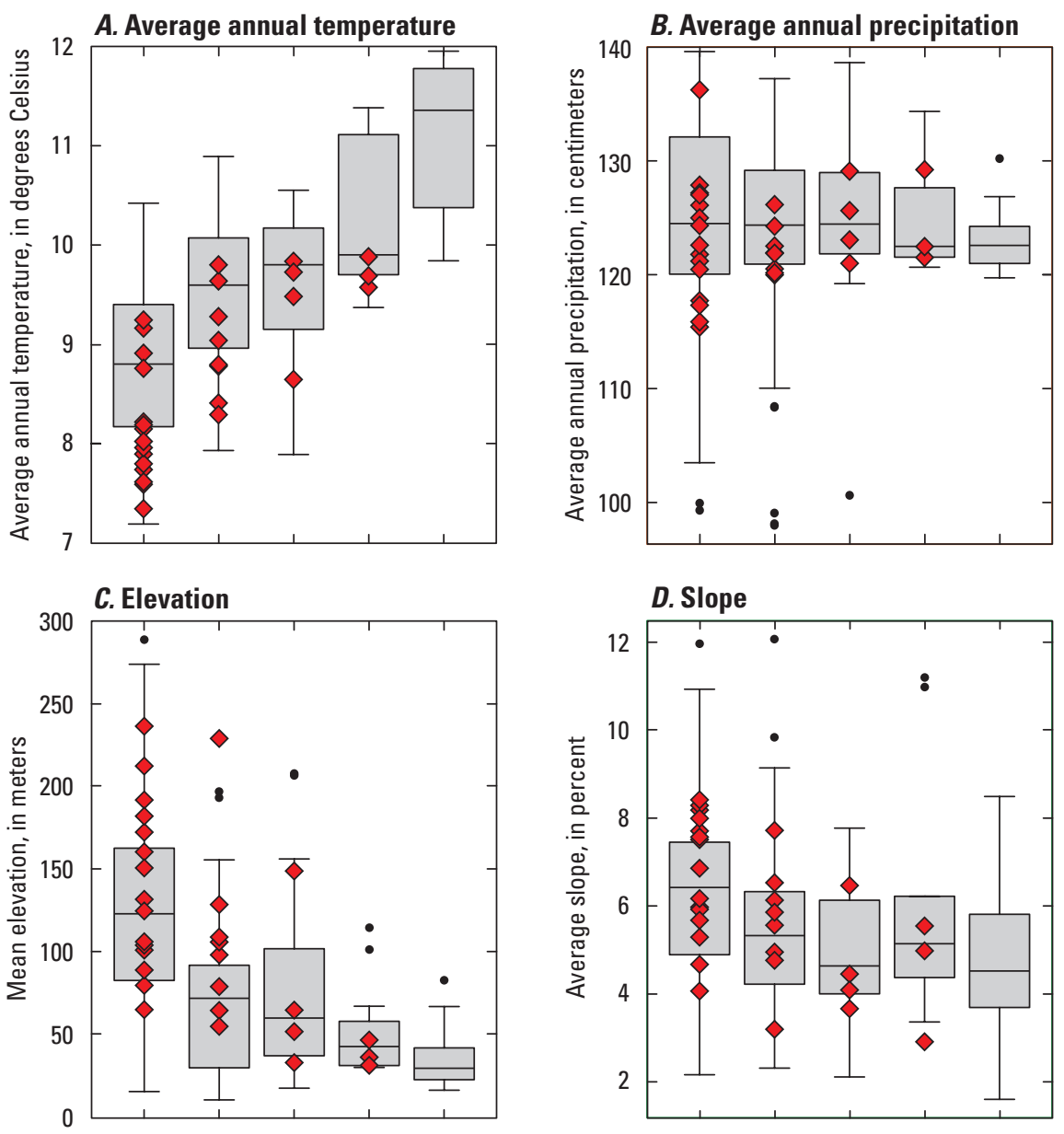

\section{EXPLANATION}

- Outlier

1.5 times the interquartile range above the box

$5^{\text {th }}$ percentile Median Interquartile 25th percentile $\begin{aligned} & \text { range } \\ & \text { thedian }\end{aligned}$

1.5 times the interquartile range below the box

$\diamond \quad$ EUSE values within development class
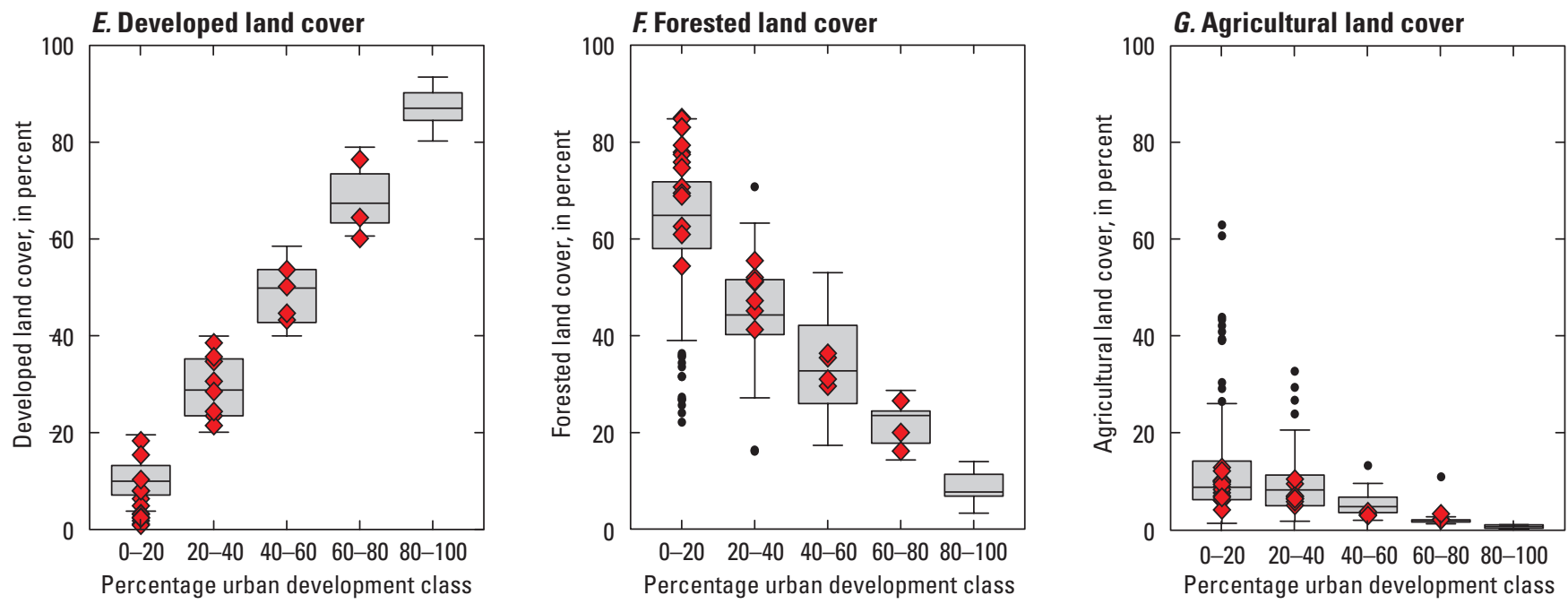

Figure 38. Summary of Northeastern Coastal Zone Level III ecoregion and Boston EUSE study watershed characteristics by percentage of urban development class. $A$, Average annual temperature. $B$, Average annual precipitation. $C$, Mean elevation. $D$, Average slope. E, Developed land cover. F, Forested land cover. G, Agricultural land cover. 

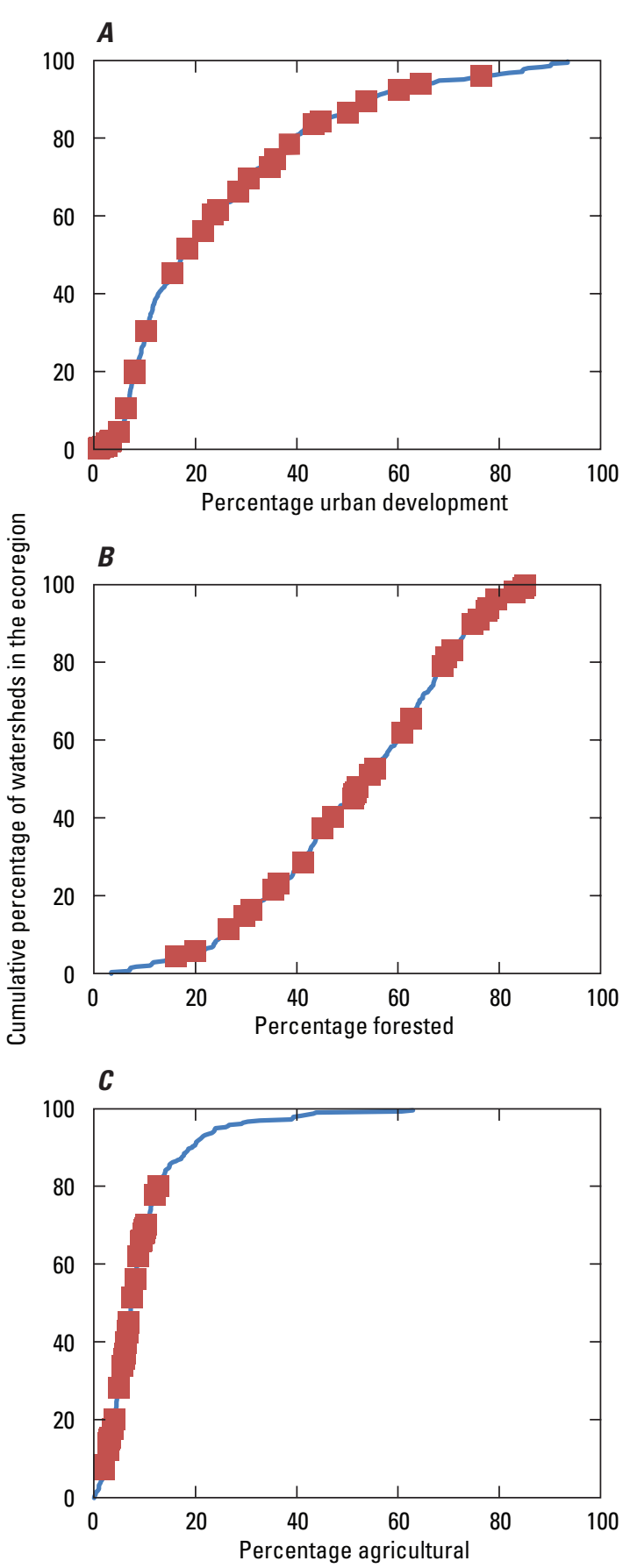

EXPLANATION

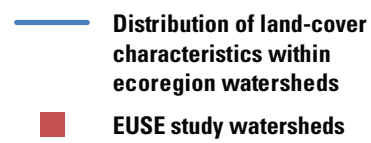

Figure 39. Cumulative distribution plot (blue line) of the percentage of $(A)$ urban development, $(B)$ forested, and $(C)$ agricultural land cover in the Northeastern Coastal Zone Level III ecoregion watersheds, and the percentage of the same land-cover types in the Boston EUSE study watersheds.

\section{Discussion}

When comparing the distribution of values between ecoregion and EUSE watersheds, three important patterns emerge for factors that can influence the condition of stream ecosystems. These patterns have implications for the use of EUSE data in models that can be used to predict stream ecosystem condition.

\section{Background Land Cover is Either Forested or Agricultural}

One important pattern is the predominance of either forested or agricultural land as the "background" land cover in the EUSE watersheds, that is, as the dominant land-cover type in the watersheds that are at the lower, or undeveloped, end of the gradient (table 3 ). In the three metropolitan areas with agriculture as the predominant land cover at the low end of the urban gradient-Denver, Dallas, and Milwaukee - the amount of agricultural land in the EUSE watersheds was either the same or lower than in the surrounding ecoregion (table 5). A similar pattern existed regarding forested land in the EUSE metropolitan areas where forested land was the dominant background land-cover type-either the same amount or a lower amount was present in the EUSE than the ecoregion. Because one of the EUSE study objectives was to represent a gradient of urban land cover, the distribution of the dominant background land-cover type in the EUSE watersheds typically was less than the distribution in the ecoregion as a whole. Given the relative scarcity of developed land cover, the selection of a set of study watersheds that encompassed a range of urban development from low to high required a bias in the distribution of the amount of other land-cover types. Of importance is that all EUSE study areas had the same predominant background land-cover type as their respective ecoregion. 


\section{Representation of the EUSE Urban Gradient Relative to the Gradient for the Entire Ecoregion}

A number of methods were used to gauge the representativeness of urban development in the EUSE watersheds to the ecoregion. When using the K-W test for similarity of populations, six of the nine EUSE metropolitan areas have a significant difference between the distribution of developed land cover in the study watersheds and in the corresponding ecoregion watersheds, with the EUSE watersheds having a larger median amount of developed land than in the corresponding ecoregion. This reflects the study objective to understand the effects of urban development on stream ecosystems. The use of an urban gradient design required, in most metropolitan areas, employing a group of watersheds with generally higher proportions of developed land than in the ecoregion watersheds. Representativeness in terms of how the amount of developed land was distributed among ecoregion watersheds was removed in EUSE watersheds in order to represent all portions of the cumulative distribution function (CDF) for developed land.

Alternately, when broken down into five quintiles of development, the ranges within each development class are well represented in both the EUSE and ecoregion. With the exception of the middle range of development for Dallas-Fort Worth (40-60 percent developed) and the highest range of development for Boston (80-100 percent developed), all EUSE studies measured the full range of values for percentage developed land.

The representativeness of the range of development conditions across the CDF is perhaps the most important overall condition for the success of this study, because of the use of the variable "percent developed land" as a predictor variable in models that predict stream ecosystem response. If the range of values for percent developed land from the EUSE watersheds do not represent the range of values for the ecoregion as a whole, models based on the EUSE data cannot be used to predict ecosystem response in areas of the ecoregion where watersheds have amounts of developed land that lie outside the EUSE watershed range.

For example, multilevel hierarchical regression was used to examine regional patterns in the responses of benthic macroinvertebrates and algae to urban development across the nine EUSE studies (Cuffney and Falcone, 2009). Linear regressions established that responses of invertebrates (intercepts and slopes) to the amount of urban development varied among the nine areas. Multilevel hierarchical regression models were able to explain these differences on the basis of region-scale predictors as well as the amount of watershed developed land. The type of land cover being converted to urban in each of the ecoregions (for example, either agricultural or forested), as well as precipitation and air temperature were regional variables that accounted for the differences in the response of macroinvertebrates to urbanization. The effects of climatic factors (temperature, precipitation) were most apparent when simulated in conjunction with antecedent agriculture. The ability of multilevel hierarchical regression to directly incorporate predictors measured at multiple spatial scales (basin, region) provides a powerful tool for understanding the response of stream ecosystems to urbanization over broad geographical areas. Unless the amount of urban development represented in the EUSE watersheds represents the range of conditions across each ecoregion, however, the usefulness of the model to predict invertebrate response to urban development in areas of the ecoregion not well represented will be limited.

\section{Climate Zones}

In seven of the nine metropolitan areas, climate variables were significantly different from climate conditions represented by the similarly sized ecoregion watersheds. Climate variables for Portland and Raleigh were not significantly different from their respective ecoregion watersheds on the basis of the K-W test results. Because climate variables were shown to be an important factor in predicting the response of macroinvertebrates to urbanization, particularly in areas in which agriculture was the predominant land cover prior to urbanization, a further subset of the Level III ecoregions may be necessary to maintain areas with similar climate characteristics. Areas of similar climate characteristics were defined that include all areas in the ecoregion with average annual precipitation and temperature within the minimum and maximum values for EUSE watersheds (fig. 40). Although watersheds in an ecoregion with climate conditions outside of the range represented by the EUSE watersheds may still be representative of the ecoregion, the relatively anomalous climate conditions of EUSE watersheds in many ecoregions may suggest the need to subset the Level III ecoregions into smaller zones for applying EUSE models to generalize results. 
A

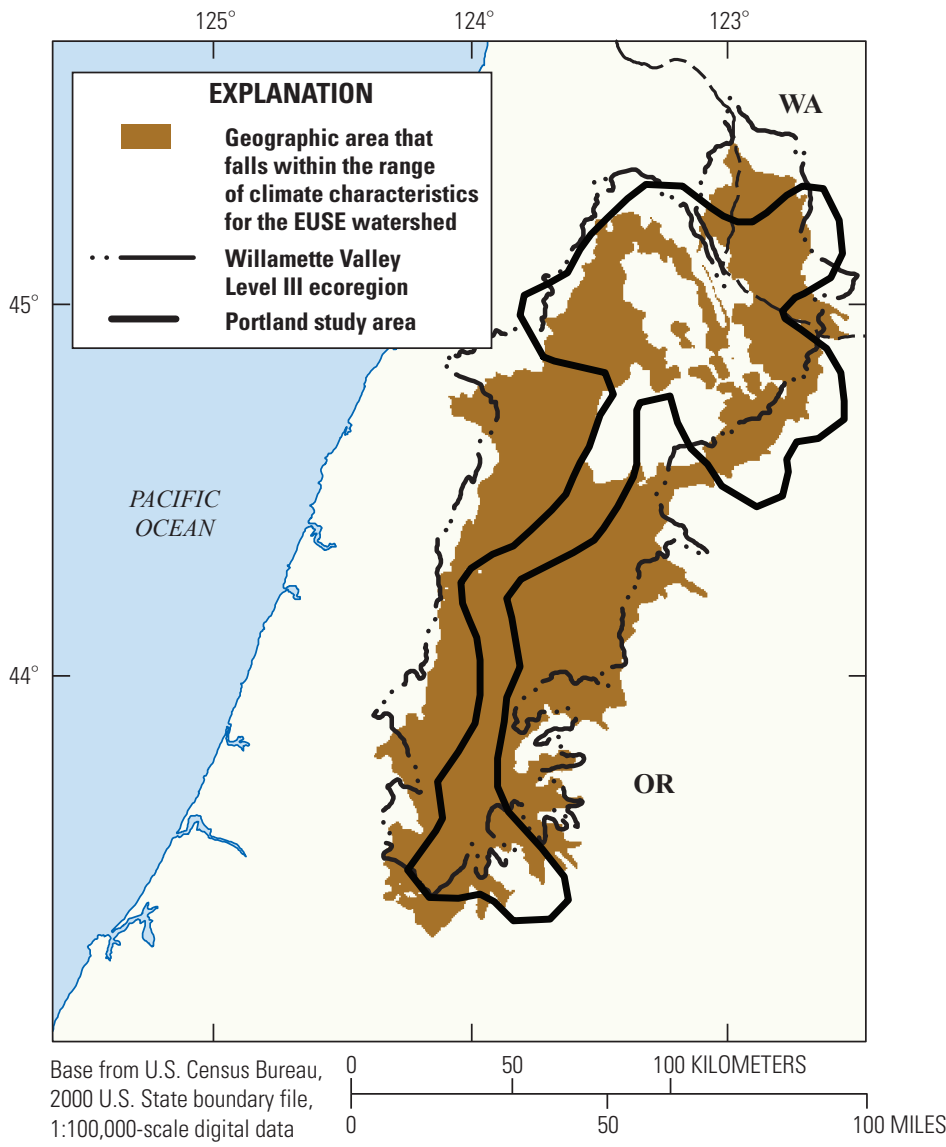

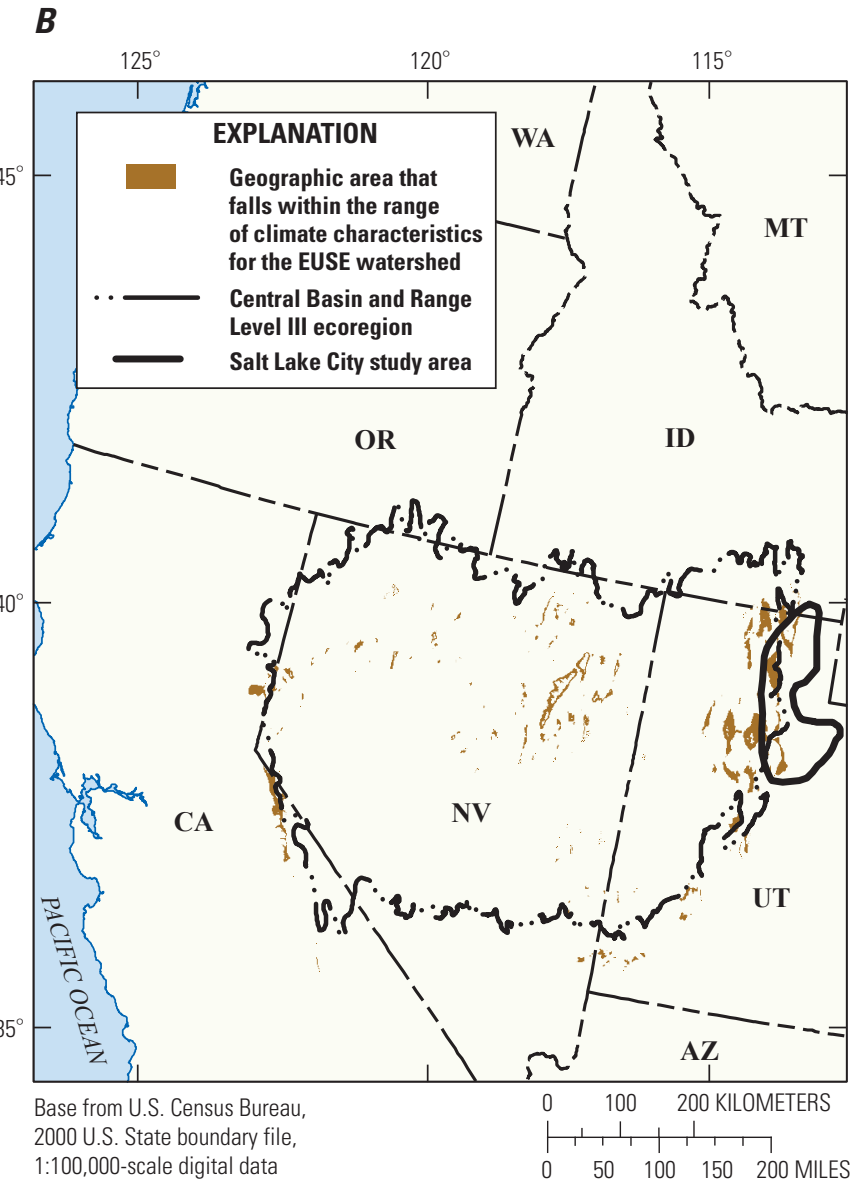

C

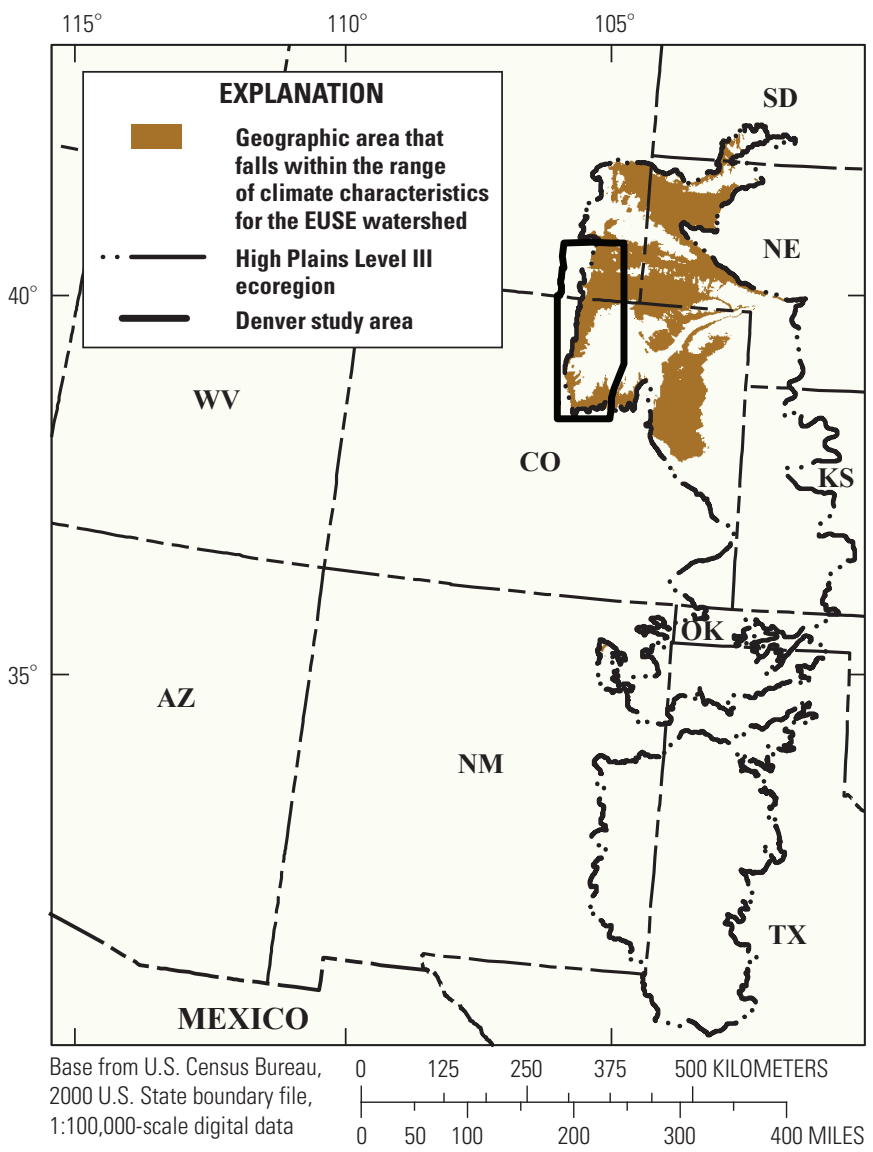

Figure 40. Climate zones within the range of precipitation and temperature values of the corresponding EUSE study watersheds. $A$, Portland. B, Salt Lake City. C, Denver. D, Dallas. E, Milwaukee. F, Birmingham. G, Atlanta. H, Raleigh. I, Boston. 
D

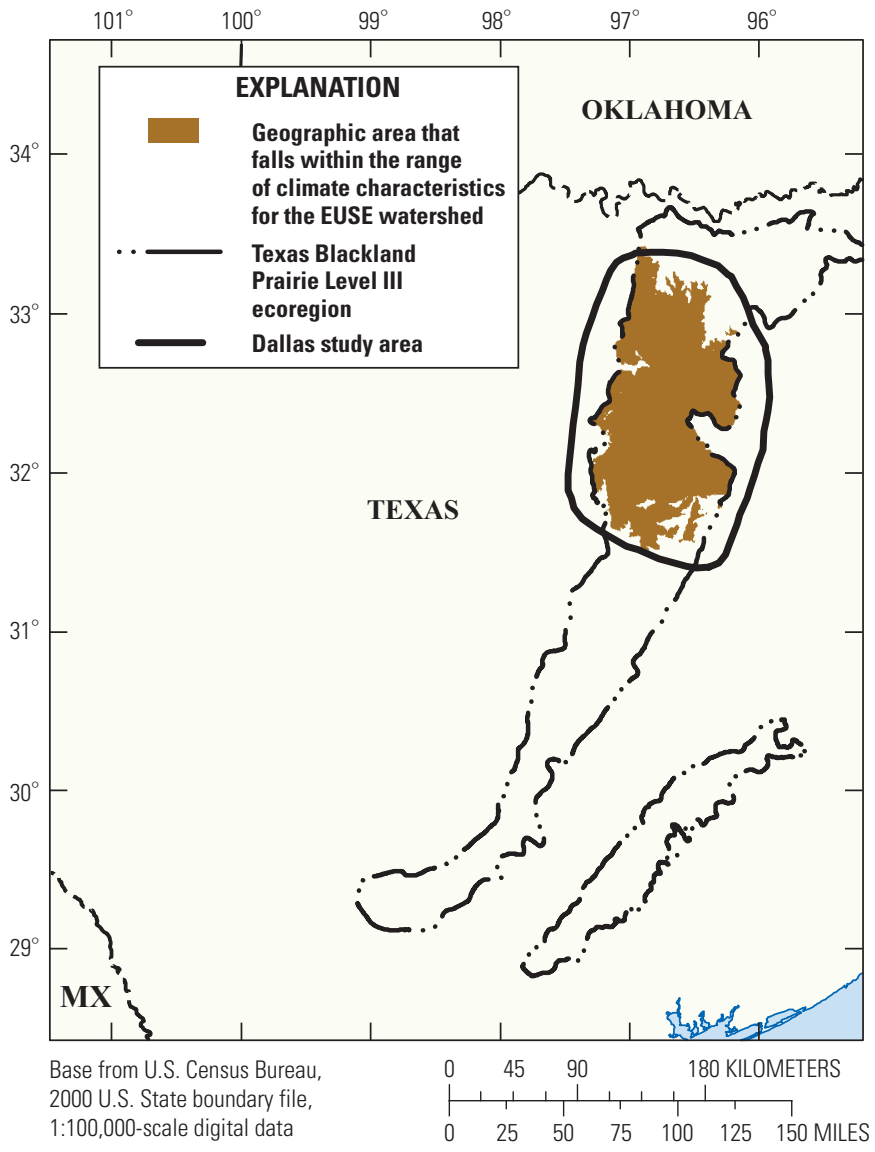

$\boldsymbol{F}$

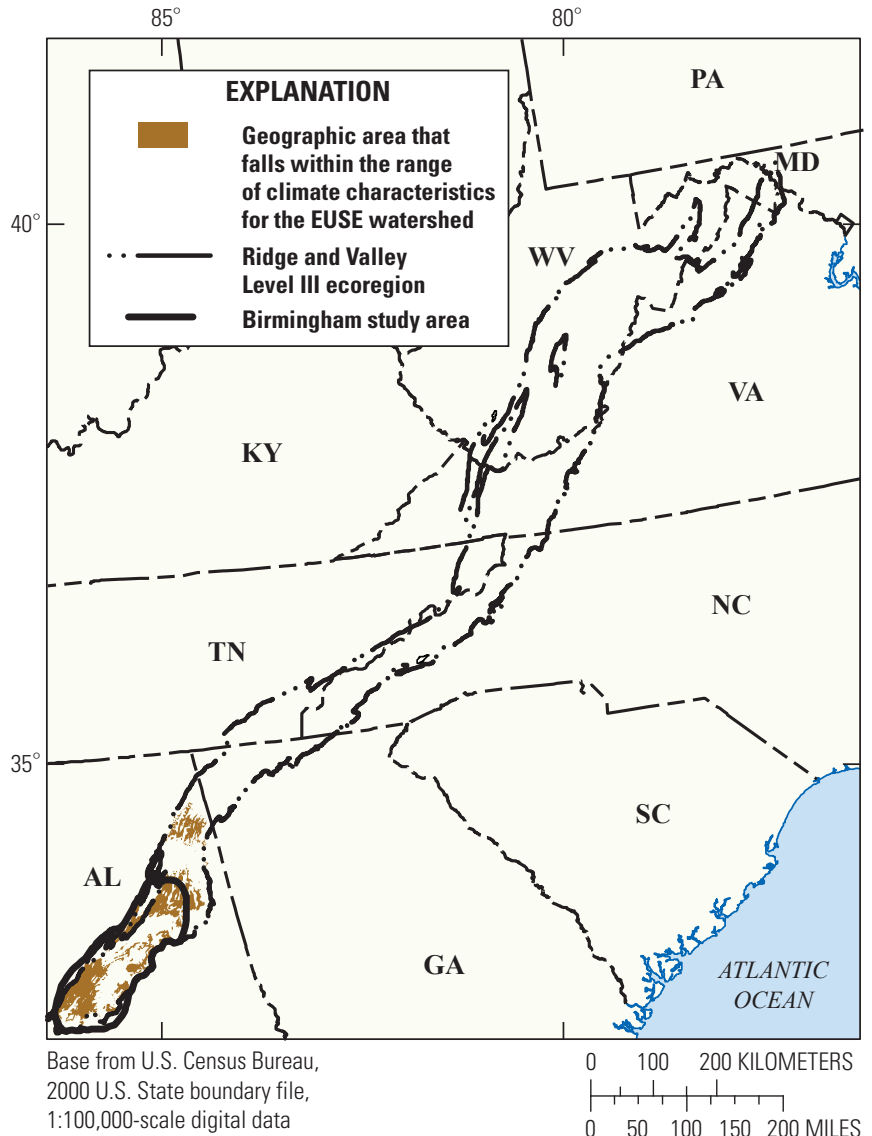

$\boldsymbol{E}$

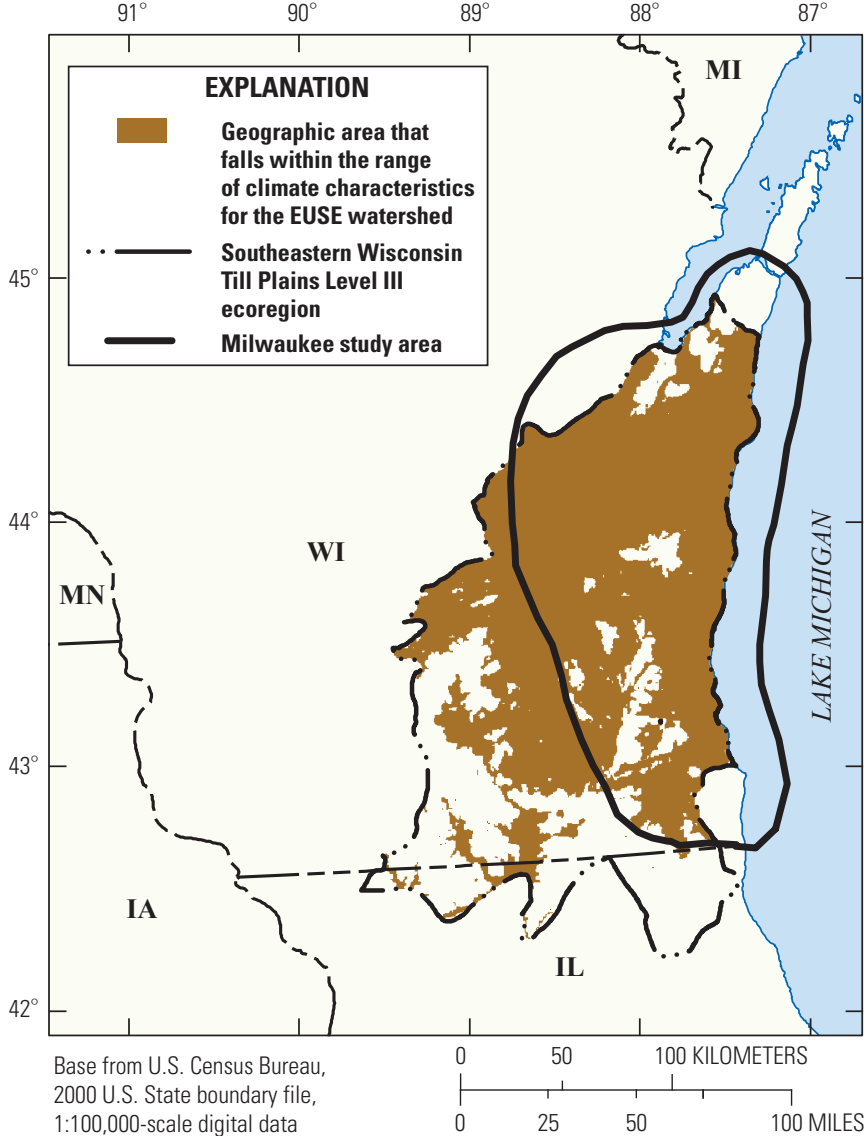

Figure 40-Continued. Climate zones within the range of precipitation and temperature values of the corresponding EUSE study watersheds. A, Portland. B, Salt Lake City. $C$, Denver. $D$, Dallas. E, Milwaukee. F, Birmingham. $G$, Atlanta. H, Raleigh. I, Boston. 
G

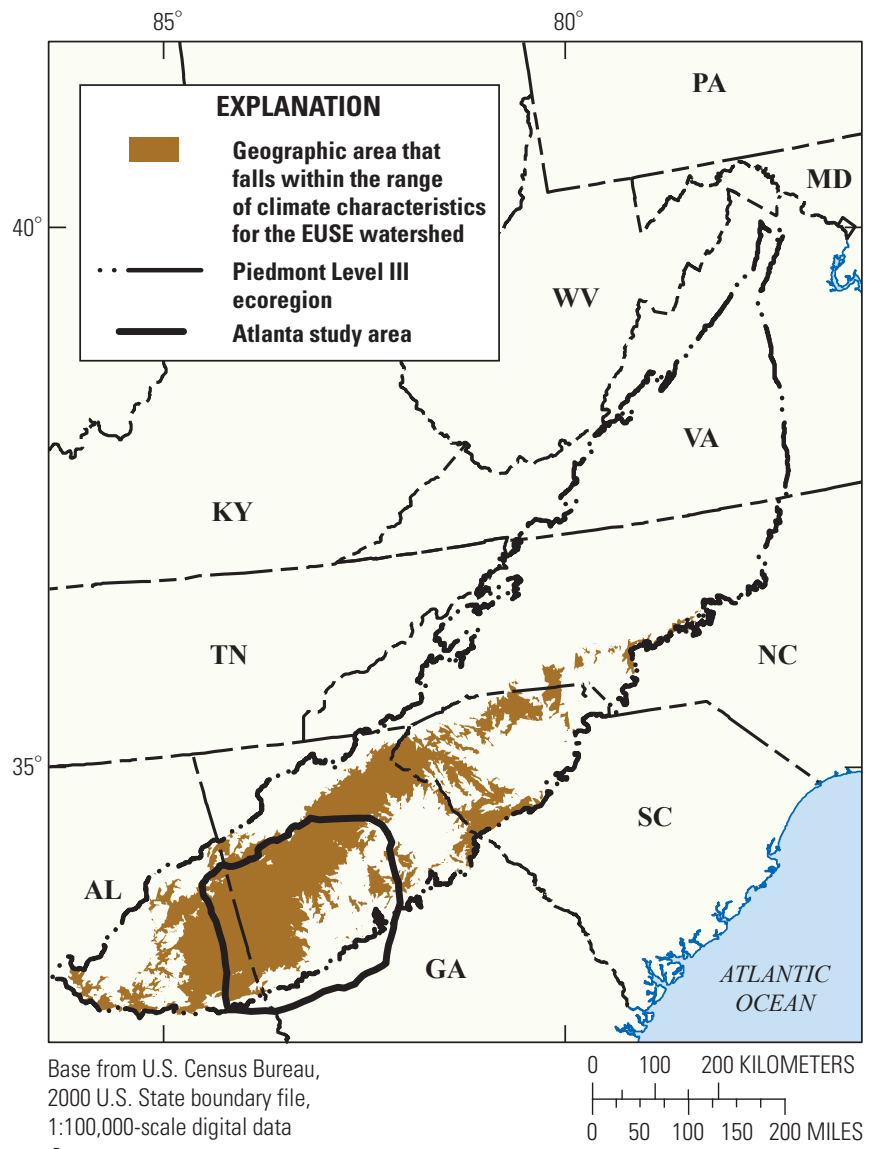

I

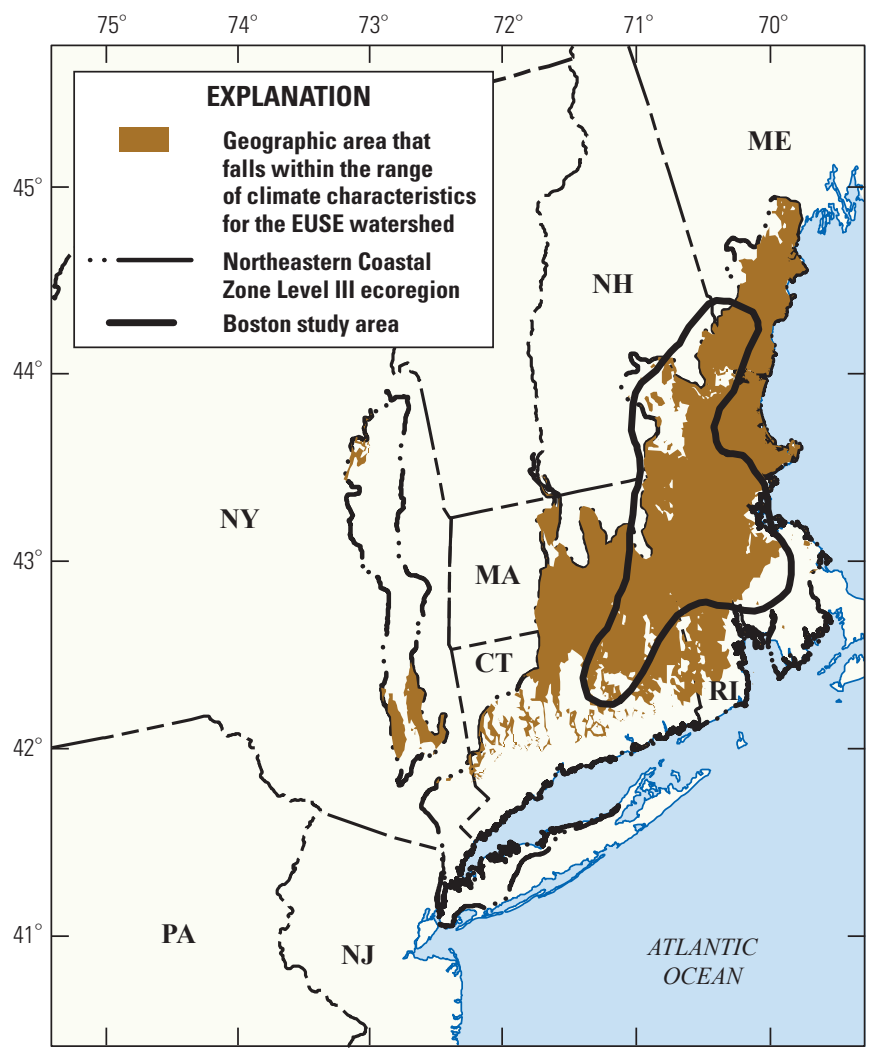

H

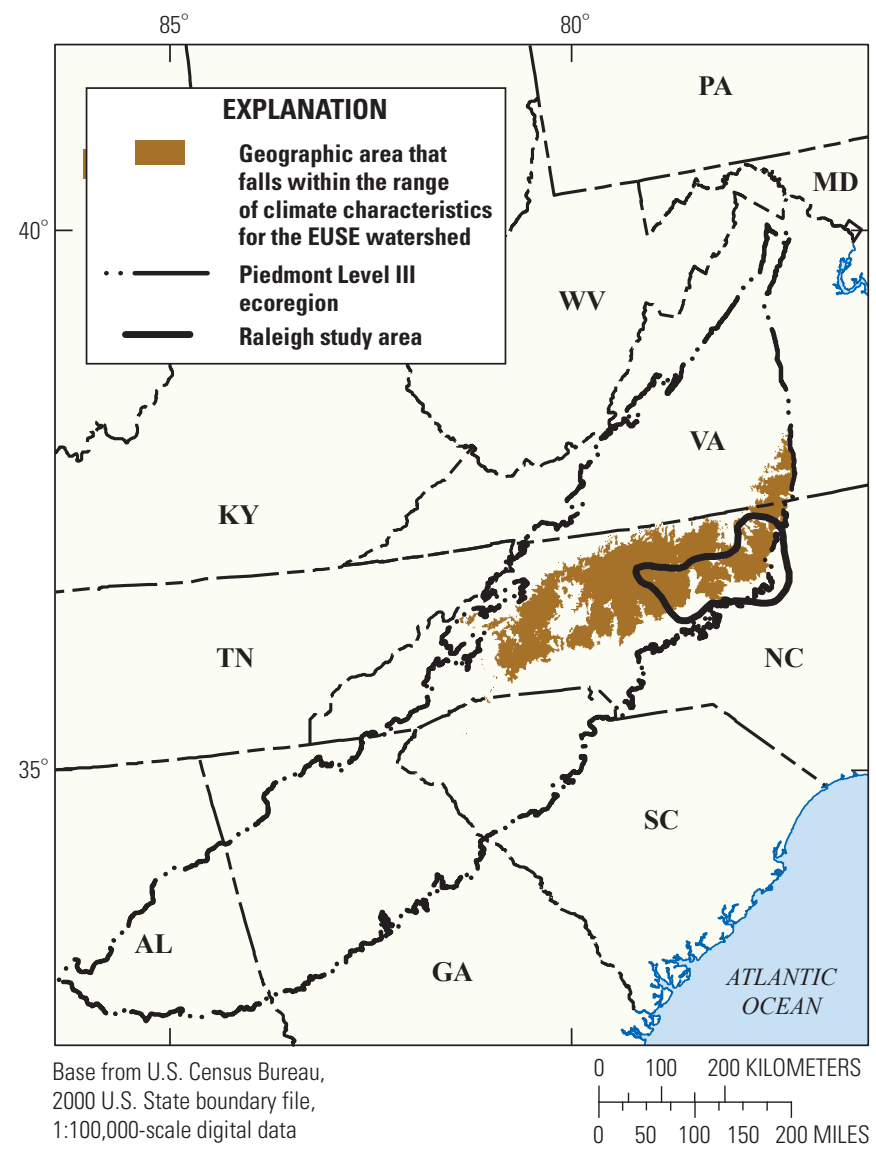

Figure 40-Continued. Climate zones within the range of precipitation and temperature values of the corresponding EUSE study watersheds. $A$, Portland. $B$, Salt Lake City. $C$, Denver. $D$, Dallas. E, Milwaukee. F, Birmingham. $G$, Atlanta. $H$, Raleigh. I, Boston.

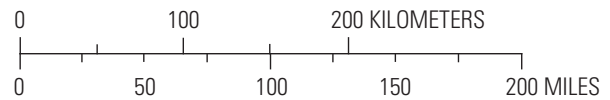




\section{Conclusions}

The nine metropolitan areas in the EUSE study-Boston, Massachusetts; Atlanta, Georgia; Birmingham, Alabama; Raleigh, North Carolina; Salt Lake City, Utah; Denver, Colorado; Dallas-Fort Worth, Texas; Portland, Oregon; and Milwaukee-Green Bay, Wisconsin - were assessed to determine if findings from each metropolitan area can be generalized across the Level III ecoregion within which the EUSE study watersheds are located. The degree to which seven characteristics of the EUSE watersheds that affect stream ecosystems - land cover (the percent developed, forest and shrubland, and herbaceous and cultivated, respectively), average annual temperature, average annual precipitation, average elevation, and average percent slope - are similar to the characteristics of the watersheds in the entire ecoregion were examined.

Three findings emerged from this comparison that have implications for the use of EUSE data in models used to predict stream ecosystem condition. The predominance of either forested or agricultural land as the "background" land cover in the EUSE watersheds that are at the lower, or undeveloped, end of the gradient was also the predominant background land-cover type for the ecoregion watersheds. The background land cover has been found to be an important variable in macroinvertebrates response to increasing urbanization. Another finding is the extent to which the distribution of developed land cover in each set of EUSE watersheds is similar to the distribution for the watersheds in the corresponding ecoregion. When looking at the distribution of development within an ecoregion, only two ecoregions have a quintile of development that were not sampled as part of the EUSE study. The highest quintile of development in the Northeastern Coastal Zone and the 40-60 percent development class in the Texas Blackland Prairie ecoregion were not represented by the Boston and Dallas EUSE studies, respectively. All other development classes were represented. Finally, with the exception of Raleigh and Portland, climate variables in the EUSE watersheds are different from the distribution for all watersheds in the corresponding ecoregion. Given the importance of climate variables in some modeling scenarios, caution may be exercised in generalizing EUSE results in Level III ecoregions corresponding to these seven metropolitan areas. Climate zones are proposed as a means of subsetting the ecoregion into areas that reflect the climate conditions of the watersheds that were sampled in the EUSE study areas.

\section{Acknowledgments}

The authors wish to thank the effects of urbanization on stream ecosystems (EUSE) teams and the work that went into developing the initial datasets associated with the EUSE study areas. Appreciation also is extended to James A. Falcone and Naomi Nakagaki of the U.S. Geological Survey for the thoughtful reviews of this report. 


\section{References}

Baskins, R.L., Waddell, K.M., Thiros, S.A., Giddings, E.M., Hadley, H.K., Stephens, D.W., and Gerner, S.J., 2002, Water-quality assessment of the Great Salt Lake Basins, Utah, Idaho, and Wyoming_-Environmental setting and study design: U.S. Geological Survey Water-Resources Investigations Report 02-4115, 47 p.

Brown, L.R., Gregory, M.B., and May, J.T., 2009, Relation of urbanization to stream fish assemblages and species traits in nine metropolitan areas of the United States: Urban Ecosystems, v. 12, no. 4, p. 391-416.

Couch, C.A., Hopkins, E.H., and Hardy, P.S., 1996, Influences of environmental settings on aquatic ecosystems in the Apalachicola-Chattahoochee-Flint River Basin: U.S. Geological Survey Water-Resources Investigations Report 95-4278, 58 p.

Cuffney, T.F., and Falcone, J.A., 2009, Derivation of nationally consistent indices representing urban intensity within and across nine metropolitan areas of the conterminous United States: U.S. Geological Survey Scientific Investigations Report 2008-5095, 36 p.

Daymet, 2005, Numerical Terradynamic Simulation Group: Missoula, Mont., University of Montana, accessed March 2011 at http://www.daymet.org.

Falcone, James, Stewart, Jana, Sobieszczyk, Steven, Dupree, Jean, McMahon, Gerard, and Buell, Gary, 2007, A comparison of natural and urban characteristics and the development of urban intensity indices across six geographic settings: U.S. Geological Survey Scientific Investigations Report 2007-5123, 43 p., 7 apps.

Flanagan, S.M., Nielsen, M.G., Robinson, K.W., and Coles, J.F., 1999, Water-quality assessment of the New England Coastal Basins in Maine, Massachusetts, New Hampshire, and Rhode Island - Environmental settings and implications for water quality and aquatic biota: U.S. Geological Survey Water-Resources Investigations Report 98-4249, 62 p.

Giddings, E.M.P., Bell, A.H., Beaulieu, K.M., Cuffney, T.F., Coles, J.F., Brown, L.R., Fitzpatrick, F.A., Falcone, James, Sprague, L.A., Bryant, W.L., Peppler, M.C., Stephens, Cory, and McMahon, Gerard, 2009, Selected physical, chemi$\mathrm{cal}$, and biological data used to study urbanizing streams in nine metropolitan areas of the United States, 1999-2004: U.S. Geological Survey Data Series 423, 11 p.
Helsel, D.R., and Hirsch, R.M., 2002, Statistical methods in water resources: U.S. Geological Survey Techniques of Water-Resources Investigations, book 4, chap. A3, 510 p.

Homer, C., Huang, C., Yang, L., Wylie, B., and Coan, M., 2004, Development of a 2001 National Landcover Database for the United States: Photogrammetric Engineering and Remote Sensing, v. 70, no. 7, p. 829-840.

Hurley, Ray, 1950, United States Census of Agriculture, accessed March 2011 at http://www.agcensus.usda.gov/ Publications/Historical_Publications/1950/vol1\%20 North\%20South\%20Carolina/41656297v1p16ch1.pdf.

Johnson, G.C., Kidd, R.E., Journey, C.A., Zappia, Humbert, and Atkins, J.B., 2002, Environmental setting and waterquality issues of the Mobile River Basin, Alabama, Georgia, Mississippi, and Tennessee: U.S. Geological Survey WaterResources Investigations Report 02-4162, 120 p.

Lambeth, T.W., 2006, Agriculture in North Carolina, Rural Data Bank: N.C. Rural Economic Development Center, accessed April 5, 2011, at http://www.ncruralcenter.org/ databank/trendpage_Agriculture.php.

McKnight, T.L., 2004, Regional geography of the United States and Canada (4th ed.): Upper Saddle River, N.J., Prentice Hall/Pearson Education, Inc., 514 p.

McMahon, Gerard, and Lloyd, O.B., 1995, Water-quality assessment of the Albermarle-Pamlico drainage basin, North Carolina and Virginia-Environmental setting and water-quality issues: U.S. Geological Survey Open-File Report 95-136, 73 p.

National Hydrography Dataset Plus, 2009, NHDPlus user guide, accessed January 2009, at ftp://ftp.horizon-systems. com/NHDPlus/documentation/NHDPLUS_UserGuide.pdf.

Omernik, J.M., 1995, Ecoregions-A spatial framework for environmental management, in Davis, W.S., and Simon, T.P., eds., Biological assessment and criteria-Tools for water resource planning and decision making: Boca Raton, Fla., Lewis Publishers, p. 49-62.

Peters, C.A., ed., 1997, Environmental setting and implications for water quality in the Western Lake Michigan Drainages, with sections by F.A. Fitzpatrick, D.W. Hall, C.A. Peters, S.J. Rheaume, D.M. Robertson, D.A. Saad, B.C. Scudder, and D.J. Sullivan: U.S. Geological Survey Water-Resources Investigations Report 97-4196, 79 p. 
Richards, K.D., Scudder, B.C., Fitzpatrick, F.A., Steuer, J.J., Bell, A.H., Peppler, M.C., Stewart, J.S., and Harris, M.A., 2010, Effects of urbanization on stream ecosystems along an agriculture-to-urban land-use gradient, Milwaukee to Green Bay, Wisconsin, 2003-2004: U.S. Geological Survey Scientific Investigations Report 2006-5101-E, 210 p.

Sprague, L.A., Zuellig, R.E., and Dupree, J.A., 2006, Effects of urbanization on stream ecosystems in the South Platte River Basin, Colorado and Wyoming: U.S. Geological Survey Scientific Investigations Report 2006-5101-A, 139 p.

Trimble, S.W., 1974, Man-induced soil erosion on the southern Piedmont, 1700-1970 (1st ed.): Ankeny, Iowa, Soil and Water Conservation Society, $180 \mathrm{p}$.
U.S. Census Bureau, 2009, Ranking tables for population of metropolitan statistical areas, micropolitan statistical areas, New England city and town areas, and combined New England city and town areas, 1990 and 2000 (June 6, 2003, ed.), Table 1a: Washington, D.C., Office of Management and Budget (PHC-T-29), accessed December 28, 2011, at http:// www.census.gov/population/www/cen2000/briefs/phc-t29/ index.html.

U.S. Geological Survey, 2005, National Elevation Dataset (NED): U.S. Geological Survey, accessed June 2009 at http://ned.usgs.gov/. 


\section{Appendix 1: Watersheds in nine metropolitan areas used in studying the effects of urbanization on stream ecosystems}

\section{Portland}

The Portland metropolitan study area is located in northwestern Oregon and southwestern Washington. The major drainage for the studied watersheds is the Willamette River, nestled between the Coast and Cascade Mountain Ranges. Most of the studied watersheds are located within the Willamette Valley ecoregion, characterized as a broad, lowland valley with a patchwork of land-use types that include evergreen forests, agriculture, urban areas, and wetlands. Landforms consist of terraces and flood plains that are interlaced and surrounded by rolling hills. Soil textures range from fine to medium-coarse. Slope and elevation in the area vary greatly from the lowland valleys to the foothills mountain range. The climate is mild with cool, wet winters and warm, dry summers.

The major metropolitan centers in the area are Portland, Vancouver, Beaverton, Salem, Corvallis, and Eugene with a combined 2000 population of 2.7 million, a 24 percent increase from 1990. Portland is the dominant commercial center of the study area with extensive port facilities on the Columbia and Willamette Rivers. The economy includes forestry and timber processing; fruit, wheat, and specialized farming; dairying; food processing; and tourism.

Table 1-1. Study watersheds located in the Portland, Oregon, metropolitan area.

\begin{tabular}{|c|c|c|c|}
\hline $\begin{array}{l}\text { Figure } \\
\text { number }\end{array}$ & $\begin{array}{l}\text { USGS station } \\
\text { identification }\end{array}$ & USGS station name & $\begin{array}{l}\text { Watershed drainage area } \\
\text { (square kilometers) }\end{array}$ \\
\hline 1 & 14199710 & Nate Creek near Colton, Oreg. & 28.75 \\
\hline 2 & 14205400 & East Fork Dairy Creek near Meacham Corner, Oreg. & 87.54 \\
\hline 4 & 14206435 & Beaverton Creek at SW 216th Ave, near Orenco, Oreg. & 95.62 \\
\hline 5 & 14206750 & Chicken Creek near Sherwood, Oreg. & 40.04 \\
\hline 8 & 434745123040200 & Silk Creek near Cottage Grove, Oreg. & 42.17 \\
\hline 9 & 435212122483300 & Lost Creek near Dexter, Oreg. & 83.42 \\
\hline 10 & 440257123103200 & Amazon Creek near Danebo Road at Eugene, Oreg. & 50.25 \\
\hline 11 & 443326123165200 & Oak Creek at Corvallis, Oreg. & 32.50 \\
\hline 12 & 445029122592600 & Battle Creek near Turner, Oreg. & 29.91 \\
\hline 16 & 451734122585400 & Chehalem Creek at Newberg, Oreg. & 97.85 \\
\hline 17 & 452149123194900 & North Yamhill Creek near Yamhill, Oreg. & 65.86 \\
\hline 18 & 452231122200000 & Deep Creek near Sandy, Oreg. & 31.36 \\
\hline 19 & 452337122243500 & North Fork Deep Creek at Barton, Oreg. & 37.01 \\
\hline 20 & 452414122213200 & Tickle Creek near Boring, Oreg. & 34.08 \\
\hline 21 & 452526122364400 & Kellogg Creek at Milwaukie, Oreg. & 34.11 \\
\hline 22 & 452912122291200 & Johnson Creek at Circle Ave, Oreg. & 55.63 \\
\hline 23 & 453506123125700 & Iler Creek near Forest Grove, Oreg. & 12.59 \\
\hline 24 & 454321122352300 & Curtin Creek near Vancouver, Wash. & 30.30 \\
\hline 25 & 454510122424900 & Whipple Creek near Salmon Creek, Wash. & 22.17 \\
\hline
\end{tabular}




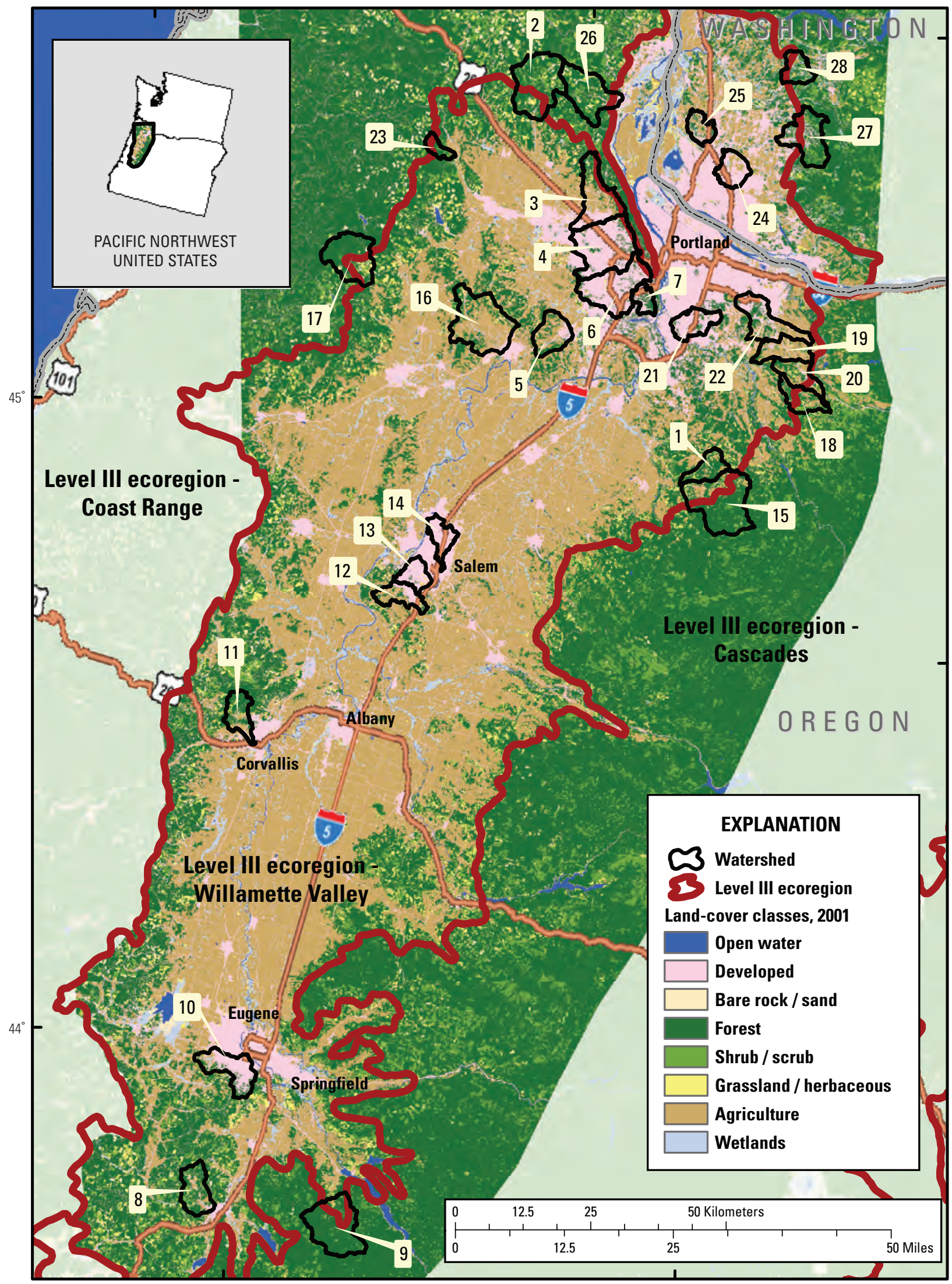

Figure 1-1. Locations of study watersheds in the Portland, Oregon, metropolitan area. 


\section{Salt Lake City}

The Salt Lake City study watersheds are located in three major river systems: the Bear, the Weber, and the Utah Lake/ Jordan River systems. These river basins, in turn, are located in the Great Basin between the Wasatch Range in the Rocky Mountains and the Sierra Nevada Mountains, a closed area that allows no outflow to other bodies of water such as rivers or oceans. The study area is characterized by cold desert basins, scattered low and high mountains, and salt flats. The climate of the study area is semiarid with most of the precipitation occurring as winter snows or occasional summer thunderstorms. The lowland valleys have moderate temperature shifts between winter and summer; whereas, the high mountains have long, cold winters and short, cool summers.
Streams in the study area arise in the Wasatch Range and flow westerly through the urban areas.

The Salt Lake City study area includes four main metropolitan areas, Salt Lake City, Logan, Ogden, and Provo. The combined 2000 population was 1.9 million, a 29 percent increase from 1990. Typical of semiarid urban areas in the western United States, an array of reservoirs, diversions, and canals alters the hydrologic regime of most Salt Lake City streams, and water rights is a continuous area of contention. Land use in the study area was historically grasslands, evergreen forests, and desert shrubs, some of which has been converted to irrigated agriculture and urban. The economy is the area is largely supported by mining, church, government, finance, education, research, high-technology industries, transportation, recreation, and tourism.

Table 1-2. Study watersheds located in the Salt Lake City, Utah, metropolitan area.

\begin{tabular}{|c|c|c|c|}
\hline $\begin{array}{l}\text { Figure } \\
\text { number }\end{array}$ & $\begin{array}{l}\text { USGS station } \\
\text { identification }\end{array}$ & USGS station name & $\begin{array}{l}\text { Watershed drainage area } \\
\text { (square kilometers) }\end{array}$ \\
\hline 1 & 10167800 & Little Cottonwood Creek at Crestwood Park at Salt Lake City, Utah & 9.87 \\
\hline 2 & 400927111354501 & Hobble Creek at 800 East at Springville, Utah & 9.64 \\
\hline 3 & 400959111363201 & Hobble Creek at Center Street at Springville, Utah & 10.63 \\
\hline 4 & 401442111402201 & Provo River at 800 North at Salt Lake City, Utah & 24.21 \\
\hline 5 & 401653111400301 & Provo River at 3700 North at Provo, Utah & 7.77 \\
\hline 8 & 403755111514201 & Little Cottonwood Creek at Wheeler Farm at Salt Lake City, Utah & 13.64 \\
\hline 9 & 403927111523601 & Little Cottonwood Creek at Murray Park at Salt Lake City, Utah & 28.91 \\
\hline 10 & 403945111501001 & Big Cottonwood Creek at Cottonwood Mall at Salt Lake City, Utah & 14.62 \\
\hline 11 & 404000111515801 & Big Cottonwood Creek at 900 East at Salt Lake City, Utah & 26.66 \\
\hline 12 & 404140111481601 & Mill Creek at 3060 East at Salt Lake City, Utah & 1.51 \\
\hline 16 & 404349111512201 & Emigration Creek at 1200 East at Salt Lake City, Utah & 4.26 \\
\hline 17 & 404430111495301 & Emigration Creek at 1300 South at Salt Lake City, Utah & 3.06 \\
\hline 18 & 405854111534801 & Farmington Creek at Frontage Road at Farmington, Utah & 3.23 \\
\hline 19 & 410041111581101 & Baer Creek at Frontage Road at Kaysville, Utah & 3.58 \\
\hline 20 & 410148111535301 & Baer Creek at Fruit Heights, Utah & 0.10 \\
\hline 21 & 410231111565001 & Holmes Creek at Main Street at Layton, Utah & 2.30 \\
\hline 22 & 410250111571501 & North Fork of Holmes Creek at Main Street at Layton, Utah & 6.91 \\
\hline 23 & 410342111574201 & Kays Creek at Layton, Utah & 14.32 \\
\hline 24 & 410453111570001 & Kays Creek at 1000 East at Layton, Utah & 10.22 \\
\hline 25 & 410501111555201 & South Fork of Kays Creek at Layton, Utah & 3.09 \\
\hline
\end{tabular}




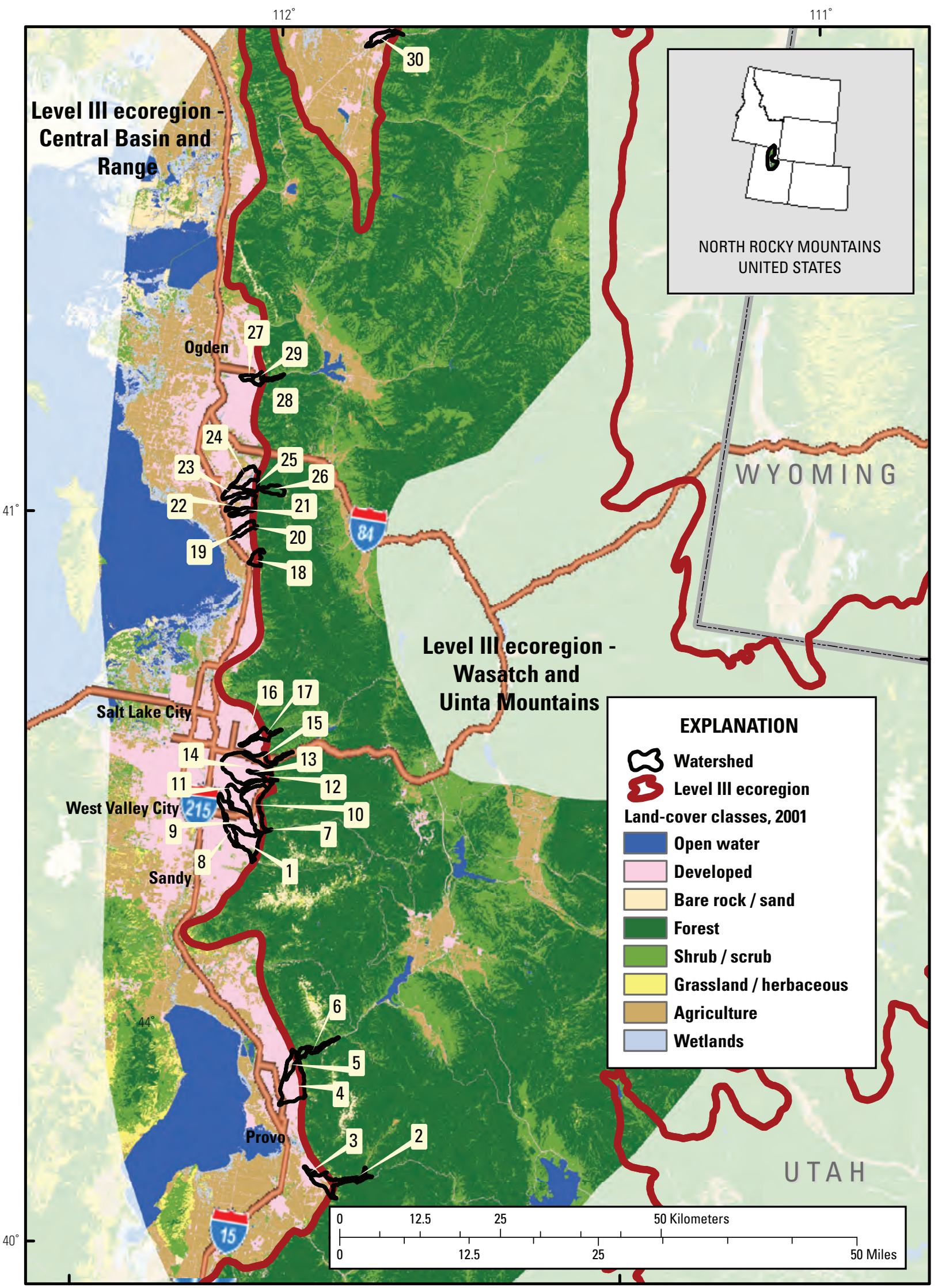

Figure 1-2. Locations of study watersheds in the Salt Lake City, Utah, metropolitan area. 


\section{Birmingham}

The Birmingham study watersheds are located in the Mobile River Basin in Georgia and Alabama in the southeastern United States, where mountain ridges typically are sandstone and valley floors primarily are limestone or shale. The climate is warm and humid with rainfall evenly distributed throughout the year, except for a dry period in August to October.
Major metropolitan centers in the study area include Birmingham, Anniston, and Gadsden, Alabama. The combined 2000 population for these three cities was 1.3 million, an 8percent increase from 1990. The dominant natural vegetative cover is Appalachian oak forest, and land use is predominantly cropland, pasture, and urban lands. Steel manufacturing is an important part of Birmingham's economy along with the medical, trade, finance, research and government fields.

Table 1-3. Study watersheds located in the Birmingham, Alabama, metropolitan area.

\begin{tabular}{|c|c|c|c|}
\hline $\begin{array}{l}\text { Figure } \\
\text { number }\end{array}$ & $\begin{array}{l}\text { USGS station } \\
\text { identification }\end{array}$ & USGS station name & $\begin{array}{l}\text { Watershed drainage area } \\
\text { (square kilometers) }\end{array}$ \\
\hline 1 & 02388518 & Little Dry Creek at US 27 at Rome, Ga. & 20.02 \\
\hline 2 & 02397939 & Chappel Creek at Long Branch Road near Trion, Ga. & 14.32 \\
\hline 3 & 02398001 & Town Branch near Summerville, Ga. & 4.70 \\
\hline 4 & 02400675 & Unnamed Tributary to Big Wills Creek at State Route 35 near Fort Payne, Ala. & 12.11 \\
\hline 5 & 02400725 & Mush Creek near Portersville, Ala. & 24.47 \\
\hline 6 & 02400800 & Little Wills Creek at Collins Chapel Road at Collinsville, Ala. & 27.88 \\
\hline 7 & 02401350 & Big Canoe Creek at Canoe Creek Road near Springville, Ala. & 54.37 \\
\hline 8 & 02401355 & Unnamed Tributary to Big Canoe Creek near Springville, Ala. & 10.50 \\
\hline 9 & 02401749 & Williams Branch near Jacksonville, Ala. & 23.92 \\
\hline 10 & 02401760 & Little Tallaseehatchee Creek near Weaver, Ala. & 38.12 \\
\hline 11 & 02403380 & Snow Creek below Anniston, Ala. & 44.72 \\
\hline 12 & 02406930 & Shirtee Creek near Odena, Ala. & 43.32 \\
\hline 13 & 02423120 & Cahaba River above Trussville, Ala. & 50.15 \\
\hline 14 & 0242339580 & Little Cahaba River near, Markeeta, Ala. & 15.70 \\
\hline 15 & 02423397 & Little Cahaba River below Leeds, Ala. & 43.95 \\
\hline 16 & 02423515 & Patton Creek near Bluff Park below Patton Chapel, Ala. & 28.77 \\
\hline 17 & 02423536 & Buck Creek at Buck Creek Road at Alabaster, Ala. & 38.70 \\
\hline 18 & 0242354650 & Cahaba Valley Creek at Indian Trail Road near Indian Springs, Ala. & 36.97 \\
\hline 19 & 0242354750 & Cahaba Valley Creek at Cross Creek Road at Pelham, Ala. & 66.07 \\
\hline 20 & 02423576 & Shades Creek at Lakeshore Drive near Mountain Brook, Ala. & 42.08 \\
\hline 21 & 02423581 & Shades Creek at Samford University at Homewood, Ala. & 56.30 \\
\hline 22 & 02423590 & Unnamed Tributary to Shades Creek near Oxmoor, Ala. & 5.99 \\
\hline 23 & 02423620 & Little Shades Creek at State Highway 150 near Bessemer, Ala. & 21.68 \\
\hline 24 & 02423729 & Dry Creek at Spring Creek Road near Montevallo, Ala. & 34.69 \\
\hline 25 & 0242372950 & Spring Creek at County Road 16 near Moores Crossroads, Ala. & 33.07 \\
\hline 26 & 02456900 & Fivemile Creek at Fivemile Road near Huffman, Ala. & 25.04 \\
\hline 27 & 02456980 & Fivemile Creek at Lawson Road near Tarrant City, Ala. & 48.66 \\
\hline 28 & 02458150 & Village Creek at East Lake in Birmingham, Ala. & 14.22 \\
\hline 29 & 02461200 & Valley Creek at Cleburn Avenue at Powderly, Ala. & 52.10 \\
\hline 30 & 02461670 & Five Mile Creek at Nevel Road near McCalla, Ala. & 33.90 \\
\hline
\end{tabular}




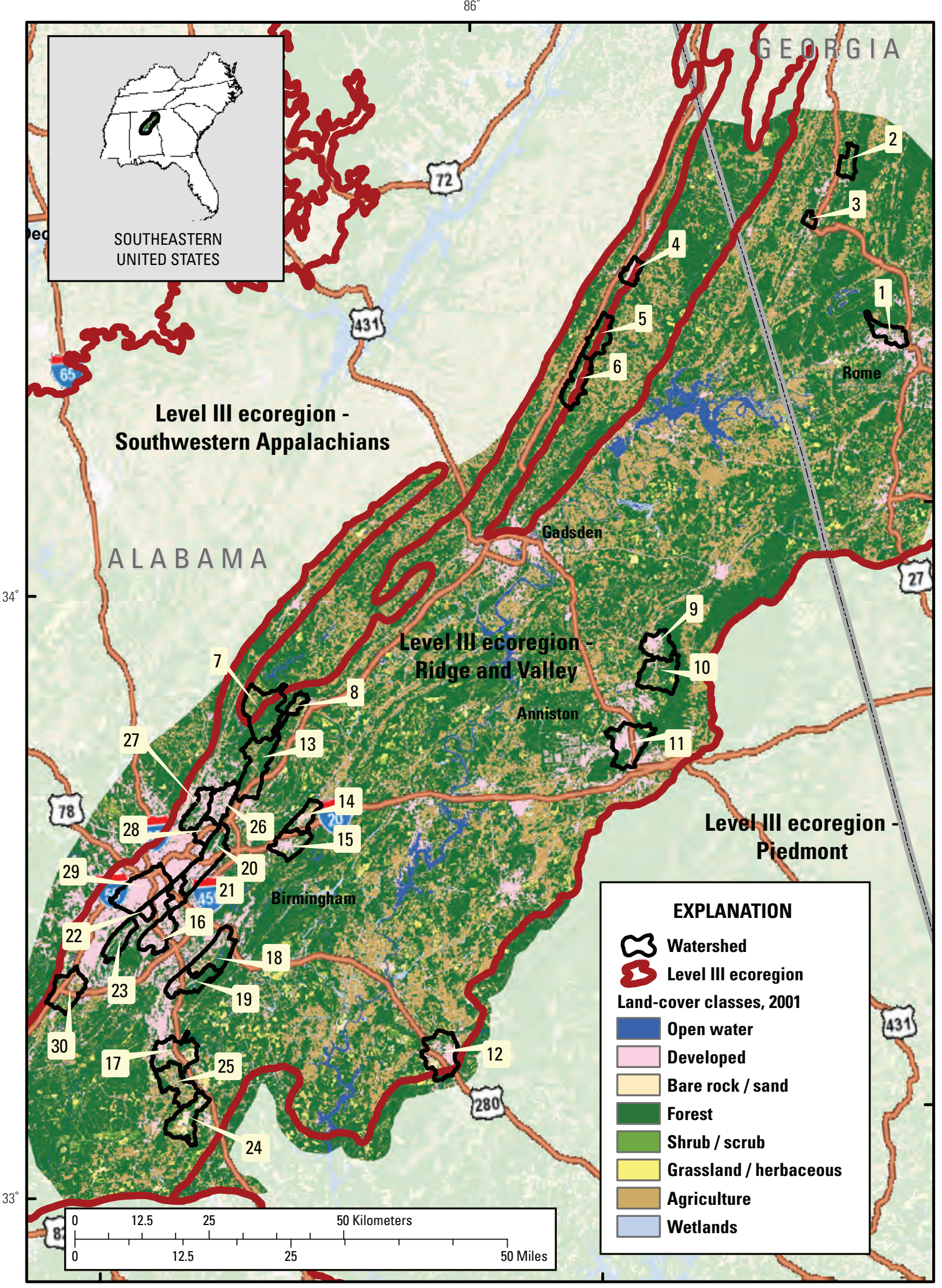

Figure 1-3. Locations of study watersheds in the Birmingham, Alabama, metropolitan area. 


\section{Atlanta}

The Atlanta study watersheds, located in northern Georgia, are characterized by gently rolling topography and dissected irregular plains. The soils are almost exclusively fine-grained sediments. The climate is warm and humid with precipitation relatively consistent throughout the year, typical of the southeastern United States. Streams in the area typically have low to moderate gradients with cobble, gravel, and sandy substrates.
Three major population centers of the area are Atlanta, Sandy Springs, and Marietta with a 2000 population of $4,247,981$, a 38.4 percent increase from 1990. Natural landcover in the Atlanta study area is oak-hickory-pine forest; however, current land use and land cover includes forested areas in silviculture and agricultural production of hay, cattle and poultry, and sprawling urban development. The economy is diversified and includes medical, industrial, commercial, and service sectors.

Table 1-4. Study watersheds located in the Atlanta, Georgia, metropolitan area.

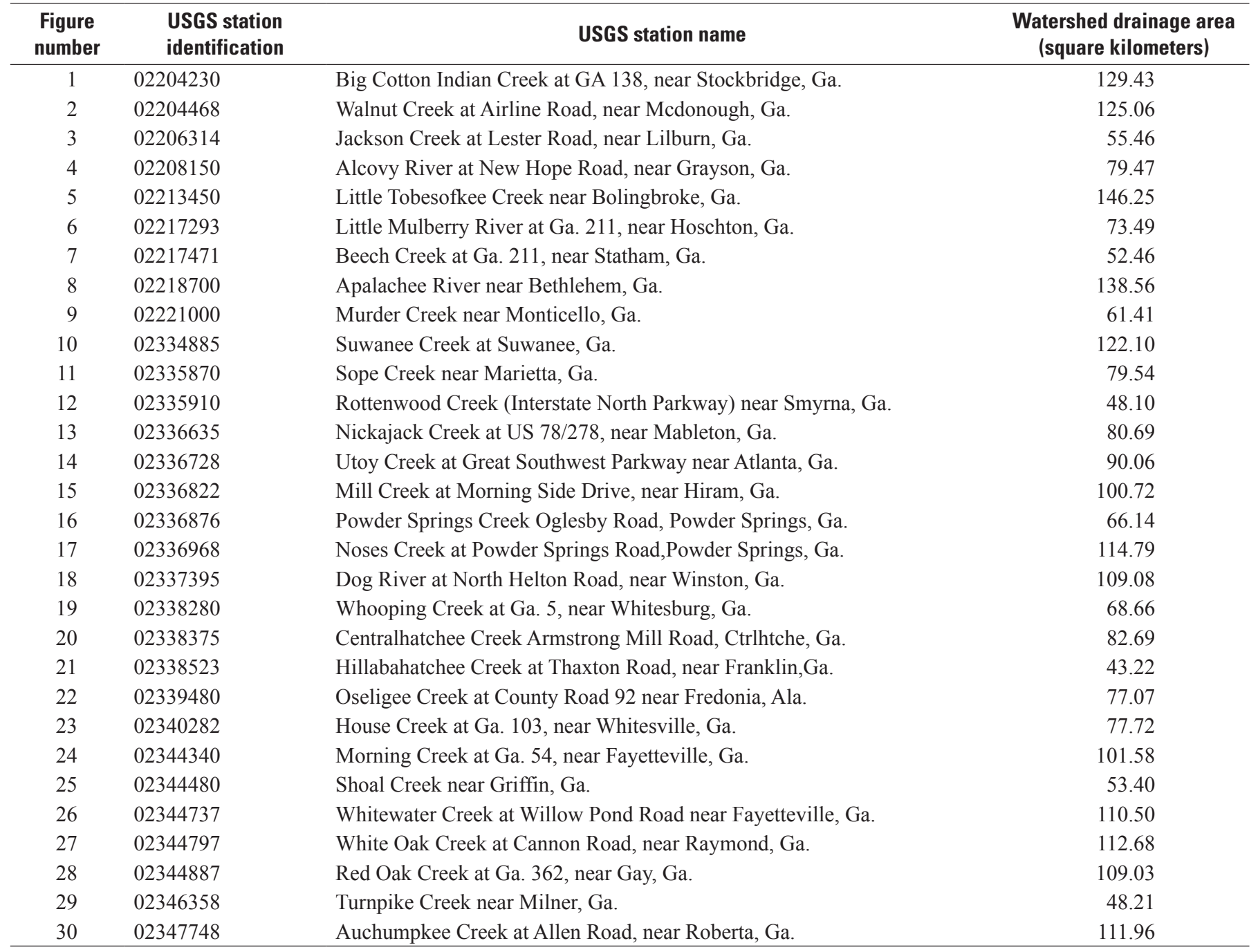




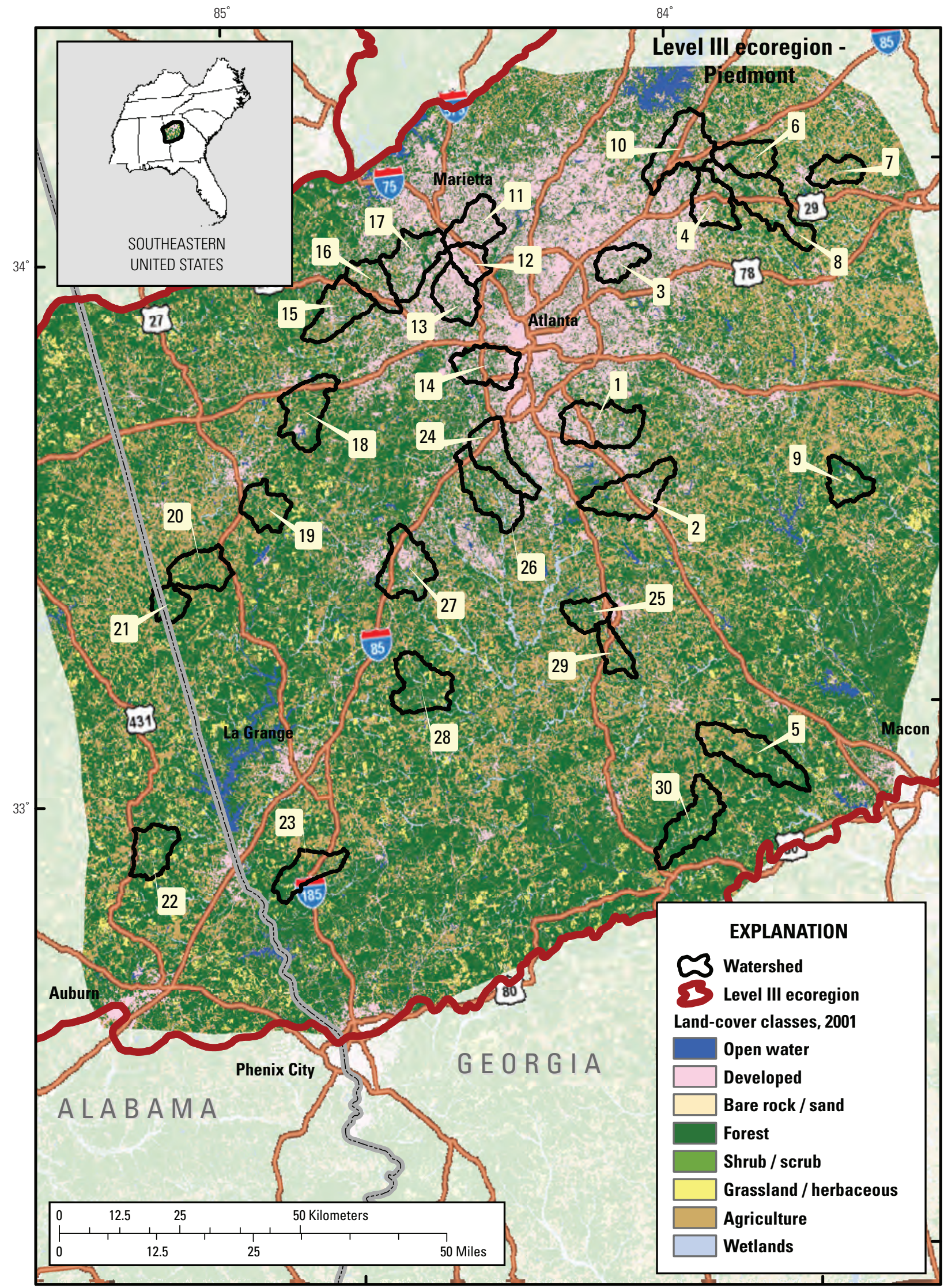

Figure 1-4. Locations of study watersheds in the Atlanta, Georgia, metropolitan area. 


\section{Raleigh}

The Raleigh study watersheds are located in central North Carolina with irregular plains and some hills. Soils in the area vary from fine to moderately fine textures in the Coastal Plain and Piedmont areas. The climate is warm and humid, with rainfall evenly distributed throughout the year. Streams in all three subecoregions have low to moderate gradients and typically have gravel to cobble substrate.

The Raleigh study area includes five population centers-Raleigh-Cary, Greensboro-High Point, Durham, Winston-Salem, and Burlington - with a combined 2000 population of 2.4 million, an increase of about 28 percent from
1990. The economy of the study area is diversified and has grown substantially in recent decades, in part as a result of the "Research Triangle" of Raleigh-Durham-Chapel Hill, a successful corporate research area associated with three nearby universities. Heavier industry, primarily textiles, tobacco, chemicals, and furniture, dominate in the western part of the study area near Winston-Salem and Greensboro. Land use in the area has undergone major transformations, from forests to agricultural lands, to forest again, and as of late, to urban and suburban lands. At one time, the region was heavily farmed in cotton, tobacco, corn, and wheat, and many areas underwent moderate to severe erosion of the silt/clay soils.

Table 1-5. Study watersheds located in the Raleigh, North Carolina, metropolitan area.

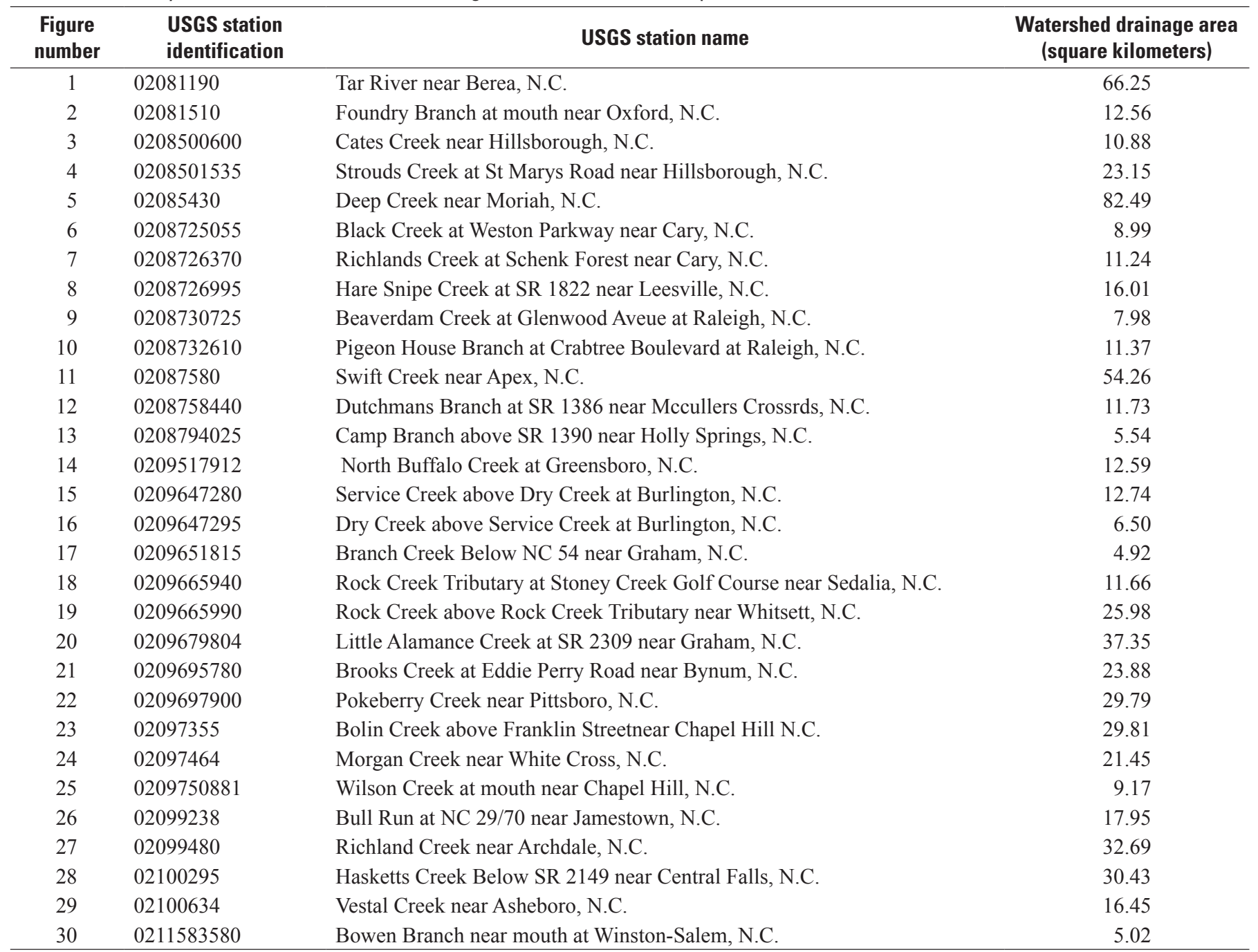




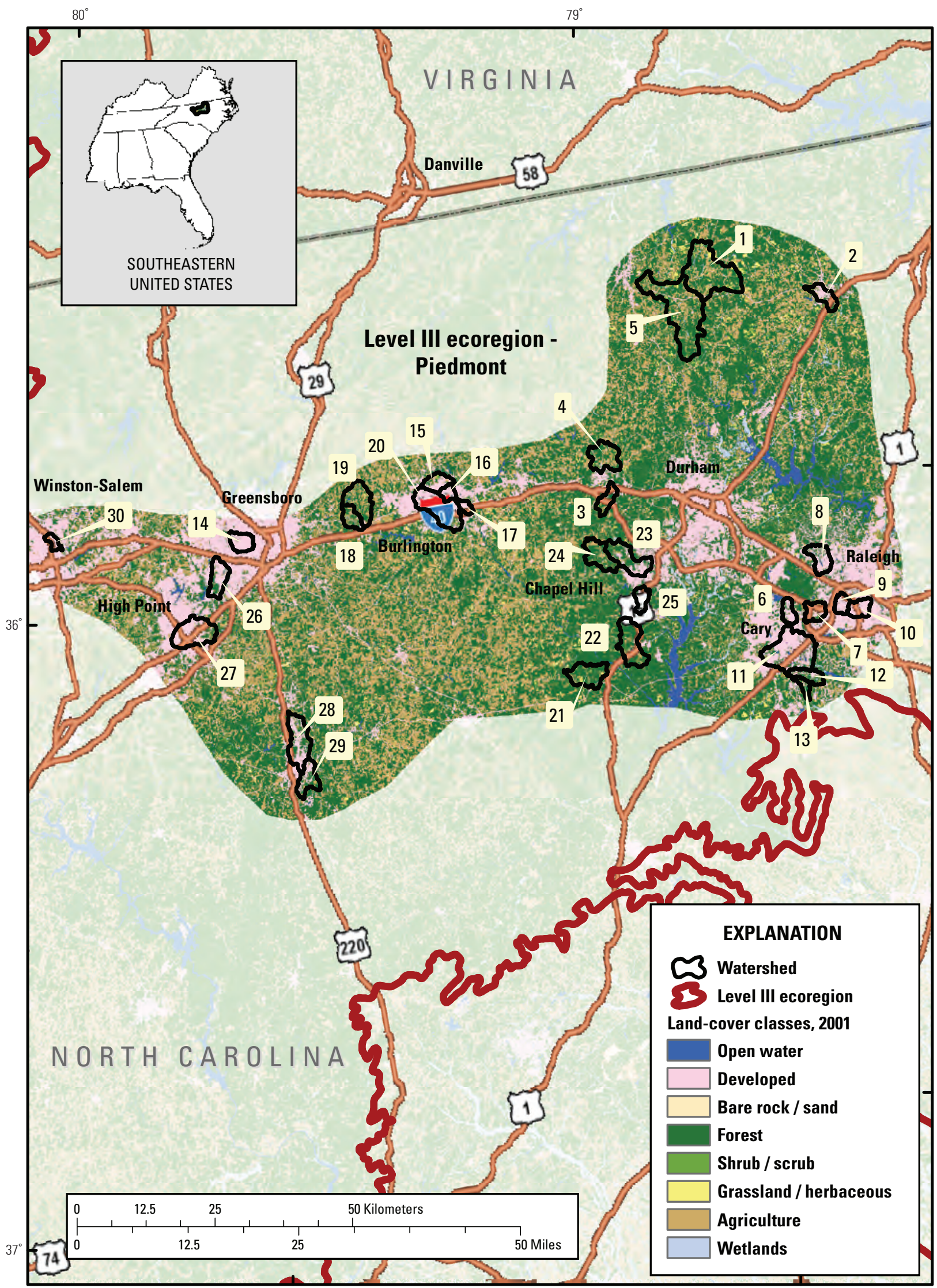

Figure 1-5. Locations of study watersheds in the Raleigh, North Carolina, metropolitan area. 


\section{Boston}

The Boston study area includes portions of Massachusetts, New Hampshire, Maine, and Connecticut. The area is characteristic of New England with moderately coarse to coarse textured soils, low hills, forests, cropland and pasture, and urban lands. The climate is cool and humid, and the area experiences frost periods and snow in winter months, although precipitation is evenly distributed throughout the year, with slightly higher amounts in the spring and fall.

The Boston study area includes portions of four cities, including Boston, Massachusetts; Worcester, Massachusetts; Concord, New Hampshire; and Manchester-Nashua, New
Hampshire. The combined 2000 population for these cities, 5.7 million, increased by about 7 percent from 1990 . The land cover currently (2011) is composed of a mix of forest, urban, and agriculture. This area was first colonized and developed in the early to mid 1600 s by immigrants from England for its location as an excellent port on the Atlantic Ocean. The natural land cover was mixed forest, but was cleared for lumber materials and the land was converted to agricultural uses. The area was allowed to revert back to forests as the industrial revolution encouraged families to abandon the farms for jobs in the cities. Many factories and mills were built along rivers, so that more than 1,600 dams in the area regulate flows in mid-sized to large rivers (basin areas greater than $250 \mathrm{~km}^{2}$ ).

Table 1-6. Study watersheds located in the Boston, Massachusetts, metropolitan area.

\begin{tabular}{|c|c|c|c|}
\hline $\begin{array}{l}\text { Figure } \\
\text { number }\end{array}$ & $\begin{array}{l}\text { USGS station } \\
\text { identification }\end{array}$ & USGS station name & $\begin{array}{l}\text { Watershed drainage area } \\
\text { (square kilometers) }\end{array}$ \\
\hline 1 & 01072540 & Little River near Lebanon, Maine & 45.85 \\
\hline 2 & 01072650 & Greatworks River near North Berwick, Maine & 60.16 \\
\hline 4 & 01072904 & Bellamy River at Bellamy Road near Dover, N.H. & 68.46 \\
\hline 5 & 01073260 & Lamprey River Cotton Road near Deerfield, N.H. & 83.09 \\
\hline 8 & 01089743 & Little Suncook River Blackhall Road at Epsom, N.H. & 101.35 \\
\hline 9 & 01090477 & Black Brook Dunbarton Road near Manchester, N.H. & 53.65 \\
\hline 10 & 01094005 & Baboosic River Bedford Road near Merrimack, N.H. & 73.00 \\
\hline 11 & 01095220 & Stillwater River near Sterling, Mass. & 78.70 \\
\hline 12 & 01096544 & Stony Brook at School Street at Chelmsford, Mass. & 107.67 \\
\hline 16 & 01097270 & Fort Pond Brook at River Road near South Acton, Mass. & 53.75 \\
\hline 17 & 01097476 & Sudbury River at Concord Street at Ashland, Mass. & 89.56 \\
\hline 18 & 01101500 & Ipswich River at South Middleton, Mass. & 115.30 \\
\hline 19 & 01102345 & Saugus River at Saugus Ironworks at Saugus, Mass. & 60.40 \\
\hline 20 & 01102500 & Aberjona River (head of Mystic River) at Winchester, Mass. & 58.20 \\
\hline 21 & 011032058 & Charles River at Maple Street at North Bellingham, Mass. & 54.20 \\
\hline 22 & 01105000 & Neponset River at Norwood, Mass. & 84.90 \\
\hline 23 & 01105500 & East Branch Neponset at Canton Junction, Mass. & 72.85 \\
\hline 24 & 01105581 & Monatiquot River at River Street at Braintree, Mass. & 71.22 \\
\hline 25 & 01106468 & Matfield River at North Central Street at East Bridgewater, Mass. & 79.75 \\
\hline
\end{tabular}




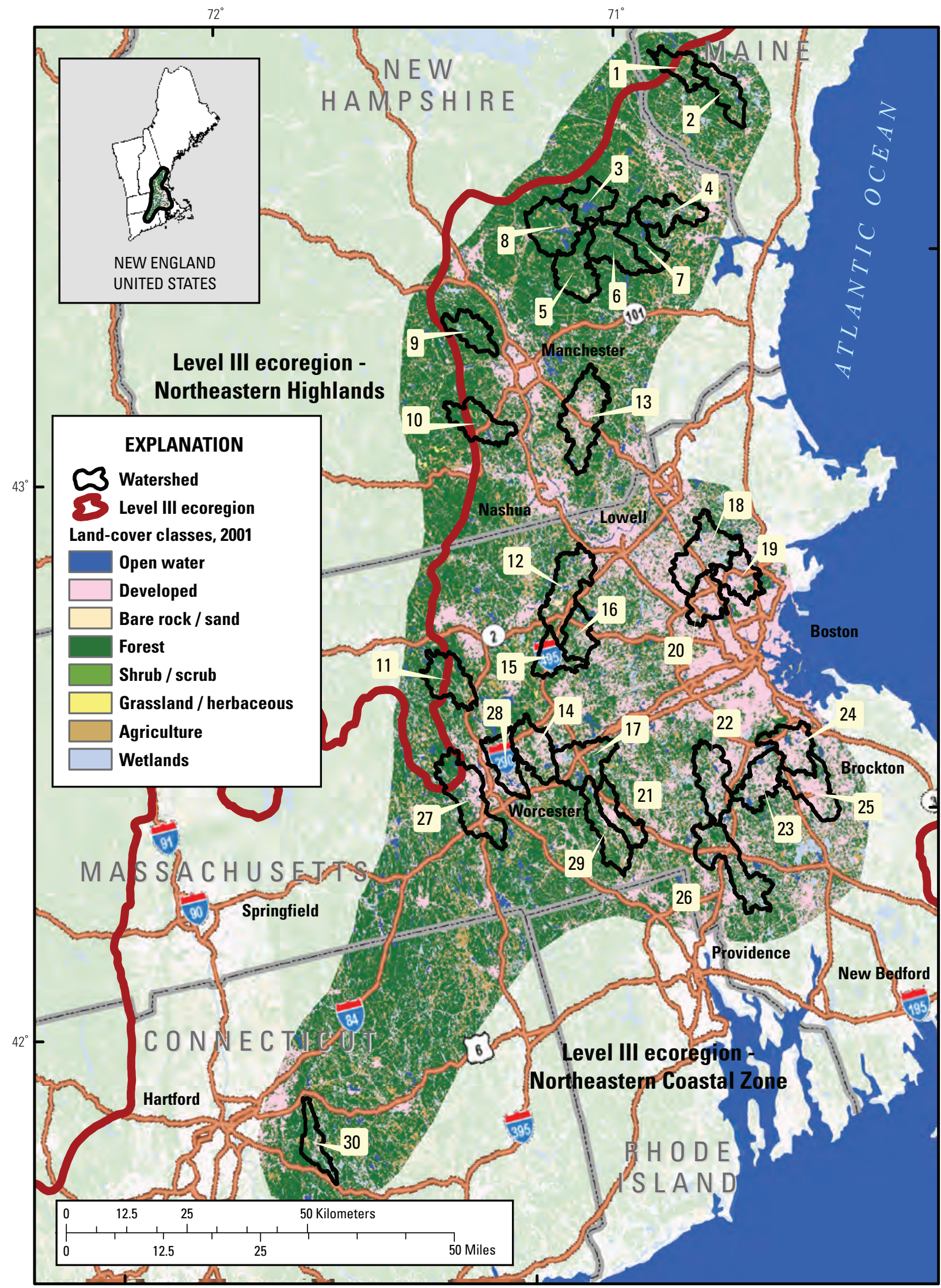

Figure 1-6. Locations of study watersheds in the Boston, Massachusetts, metropolitan area. 


\section{Denver}

The major drainage basin in the Denver study area is the South Platte River and includes portions of north-central Colorado and southeastern Wyoming. Elevation in the study area ranges from about 1,500 to 2,500 meters above NAVD 88, although the study area is bordered on the west by the Southern Rockies ecoregion, where elevations are considerably higher. The climate is semiarid, and precipitation in the study area is affected considerably by topography. Most of the precipitation on the plains results from rainfall, primarily between April and September; however, perennial streamflow also is fed by snowmelt from the mountains. Smaller streams are often ephemeral, and a complex network of ditches and pipes moves water between different areas for domestic water supply, agricultural irrigation, and power generation. Land cover in the study area is dominated by grassland and agriculture in the plains and coniferous forest in the western mountains.

The Denver study area includes four main city centers-Denver-Aurora, Boulder, and Fort Collins-Loveland, Colorado, and Cheyenne, Wyoming. The combined 2000 population for these four cities, 2.8 million, was a 30 percent increase from 1990. The economy is diversified and includes telecommunications, software, agriculture, mining, and heavy industry. Denver is a major regional center for U.S. Government offices, a transportation hub, and a tourist gateway to the mountain recreational areas of the southern Rockies.

Table 1-7. Study watersheds located in the Denver, Colorado, metropolitan area.

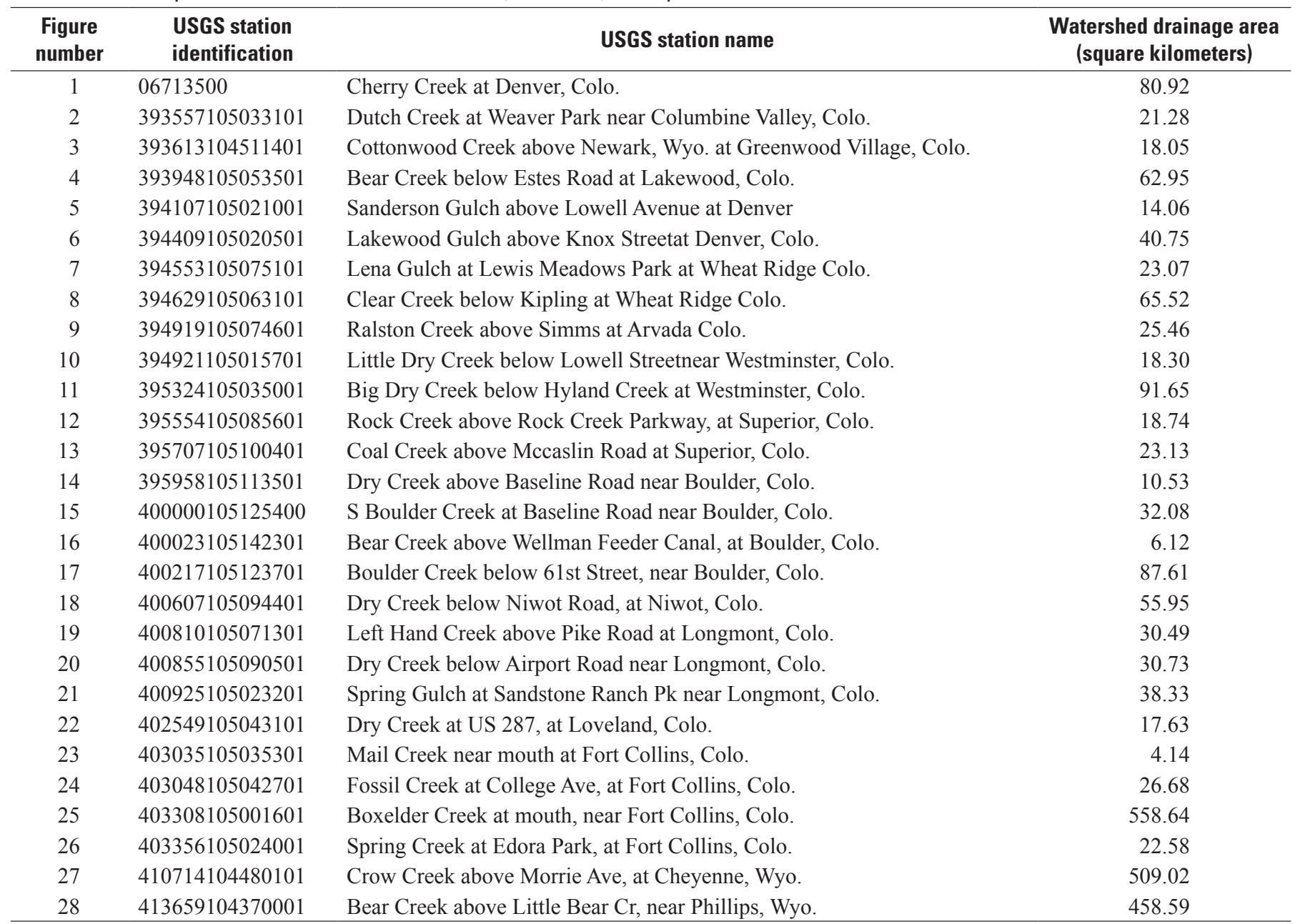




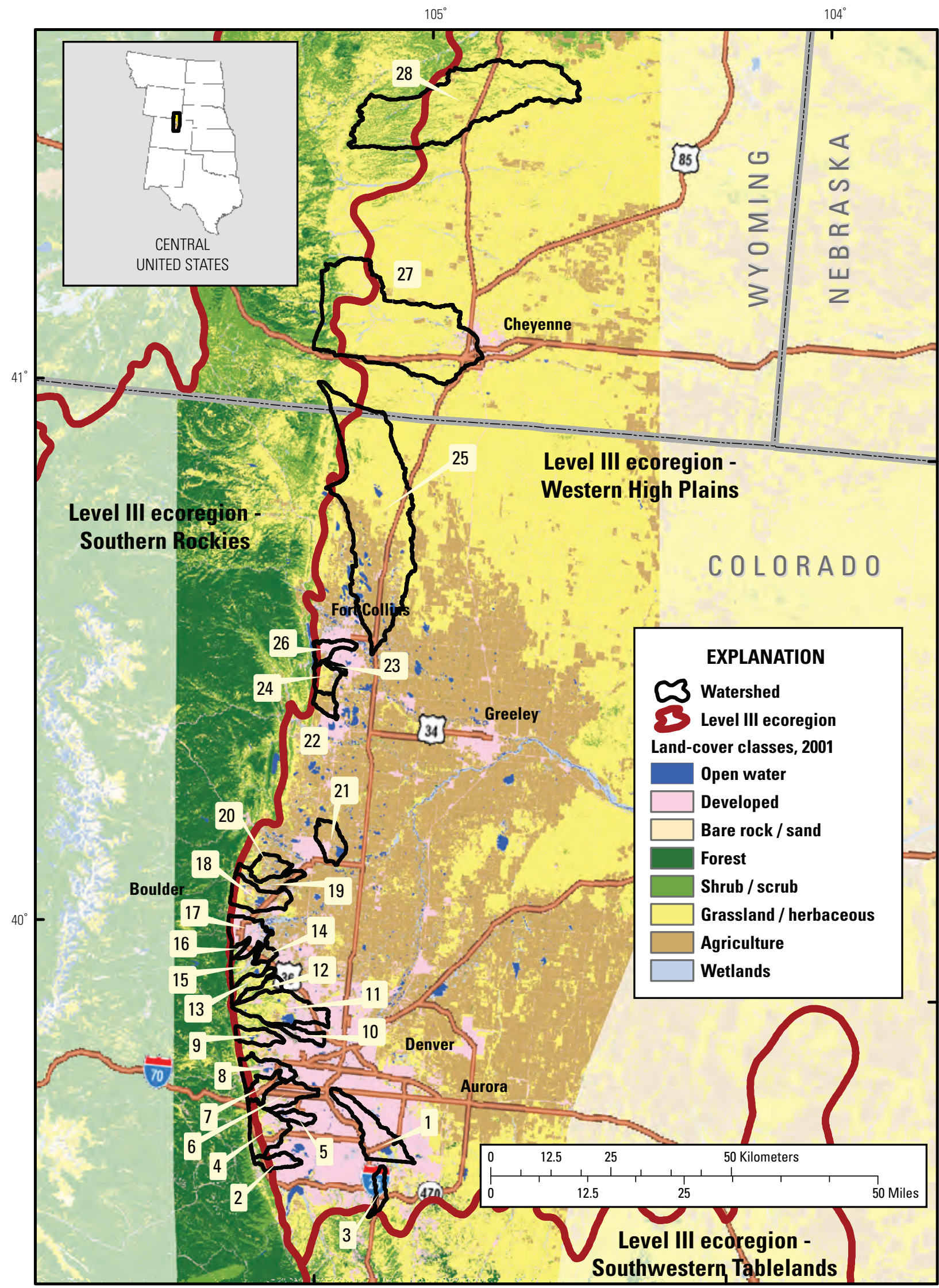

Figure 1-7. Locations of study watersheds in the Denver, Colorado, metropolitan area. 


\section{Dallas}

The Dallas study area is located in the upper drainage of the Trinity River watershed in north-central Texas, which is an area of generally rolling to level plains. The soil texture is primary fine to moderately fine. The climate is warm and semiarid, with precipitation occurring primarily in the spring and late summer. Surface water in the study area consists primarily of reservoirs, intrawatershed transfers, diversions of water to municipalities, and wastewater effluent. Small streams in the area are generally intermittent. Land cover includes grasslands, pastures, row crops, and developed land.

The predominant metropolitan area of the Dallas metropolitan study area is Dallas-Fort Worth-Arlington, with a population in 2000 of 5 million, a 29.4 percent increase since 1990. Dallas is a major regional center, and the economy includes finance, oil, transportation, aerospace, and electronics. Fort Worth, a twin city to Dallas, has an economic focus based on cattle, railways, and agricultural processing.

Table 1-8. Study watersheds located in the Dallas, Texas metropolitan area.

\begin{tabular}{|c|c|c|c|}
\hline $\begin{array}{l}\text { Figure } \\
\text { number }\end{array}$ & $\begin{array}{l}\text { USGS station } \\
\text { identification }\end{array}$ & USGS station name & $\begin{array}{l}\text { Watershed drainage area } \\
\text { (square kilometers) }\end{array}$ \\
\hline 1 & 08049490 & Johnson Creek near Duncan Perry Road, Grand Prairie, Tex. & 43.23 \\
\hline 2 & 08049580 & Mountain Creek near Venus, Tex. & 51.96 \\
\hline 3 & 08049955 & Fish Creek at Belt Line Road, Grand Prairie, Tex. & 58.27 \\
\hline 4 & 08052740 & Doe Branch at Fishtrap Road near Prosper, Tex. & 94.53 \\
\hline 5 & 08057200 & White Rock Creek at Greenville Ave, Dallas, Tex. & 173.01 \\
\hline 8 & 08059530 & Tickey Creek near CR 400 near Princeton, Tex. & 26.81 \\
\hline 9 & 08059571 & Wilson Creek near Gray Branch Road near Mckinney, Tex. & 80.96 \\
\hline 10 & 08061536 & Spring Creek at Naaman School Road near Garland, Tex. & 91.09 \\
\hline 11 & 08061740 & Duck Creek at Town East Boulevard near Mesquite, Tex. & 102.33 \\
\hline 12 & 08061780 & Buffalo Creek near Trinity Road at Forney, Tex. & 88.16 \\
\hline 16 & 08062090 & Red Oak Creek near Hampton Road near Red Oak, Tex. & 53.82 \\
\hline 17 & 08062525 & Walker Creek near Oil Field Road near Rosser, Tex. & 59.26 \\
\hline 18 & 08062550 & Bois D'Arc Creek near CR 4072 near Rosser, Tex. & 57.89 \\
\hline 19 & 08062600 & Grays Creek at CR 1603 near Rice, Tex. & 64.83 \\
\hline 20 & 08062805 & Williams Creek near FM 1836 near Kemp, Tex. & 68.04 \\
\hline 21 & 08063047 & Bynum Creek near FM 308 near Malone, Tex. & 52.78 \\
\hline 22 & 08063300 & Pin Oak Creek near FM 73 near Coolidge, Tex. & 101.68 \\
\hline 23 & 08063510 & Little Pin Oak Creek near Ih 45 near Richland, Tex. & 40.87 \\
\hline 24 & 08063555 & S Fk Chambers Creek near CR 102 near Maypearl, Tex. & 291.37 \\
\hline 25 & 08063565 & Mill Creek at Lowell Road near Milford, Tex. & 80.37 \\
\hline
\end{tabular}




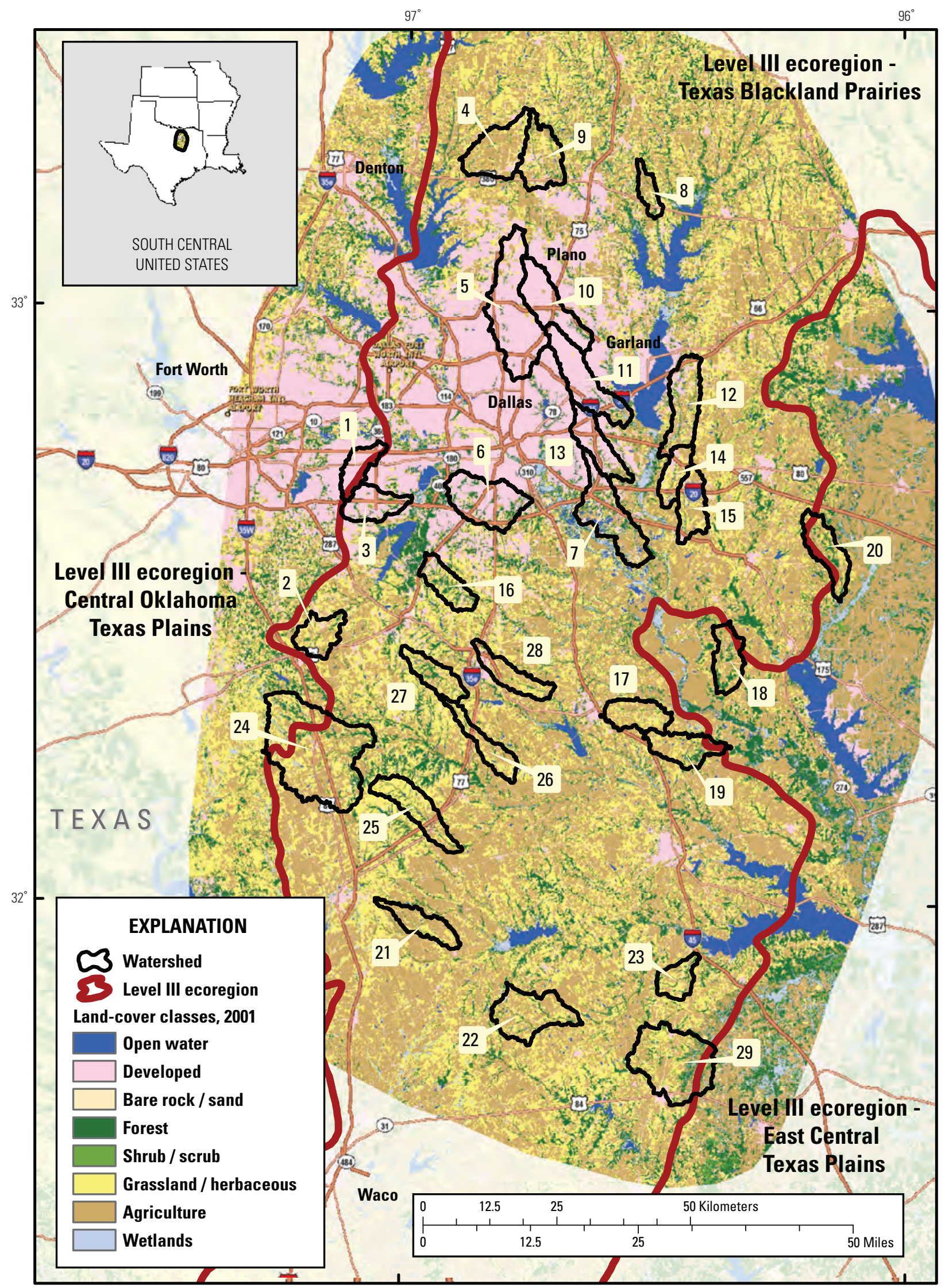

Figure 1-8. Locations of study watersheds in the Dallas, Texas, metropolitan area. 


\section{Milwaukee}

The Milwaukee study area is located in the southeastern United States along the Lake Michigan shoreline. Land surface is characterized by glacial outwash plains, lacustrine watersheds, level to rolling till plains, and extensive wetland areas. The climate is characterized by cold winters and moderate, wet summers, with most of the precipitation occurring between May and September. Highest streamflows usually occur in March through May as a result of snowmelt or a combination of rain and snow; however, summer thunderstorms can produce flood peaks that exceed snowmelt peaks. The presettlement land cover was a mixture of hardwood forests (north), oak savannas (west), and tall-grass prairies (south).
The Milwaukee metropolitan study area includes five main population centers-Milwaukee-Waukesha-West Allis, Green Bay, Appleton, Racine, and Oshkosh-Neenah. The combined 2000 population for these five areas, 2.3 million, was an 8 percent increase from 1990. Milwaukee and Green Bay offer the largest industrial, manufacturing, and commercial centers of the study area for their shipping ports. Milwaukee is has a reputation in the brewing industry; whereas, Green Bay is known for its meat packing industry. Dairy and livestock farming and associated corn and soybean production represent the dominant land use in the region.

Table 1-9. Study watersheds in the Milwaukee, Wisconsin, metropolitan area.

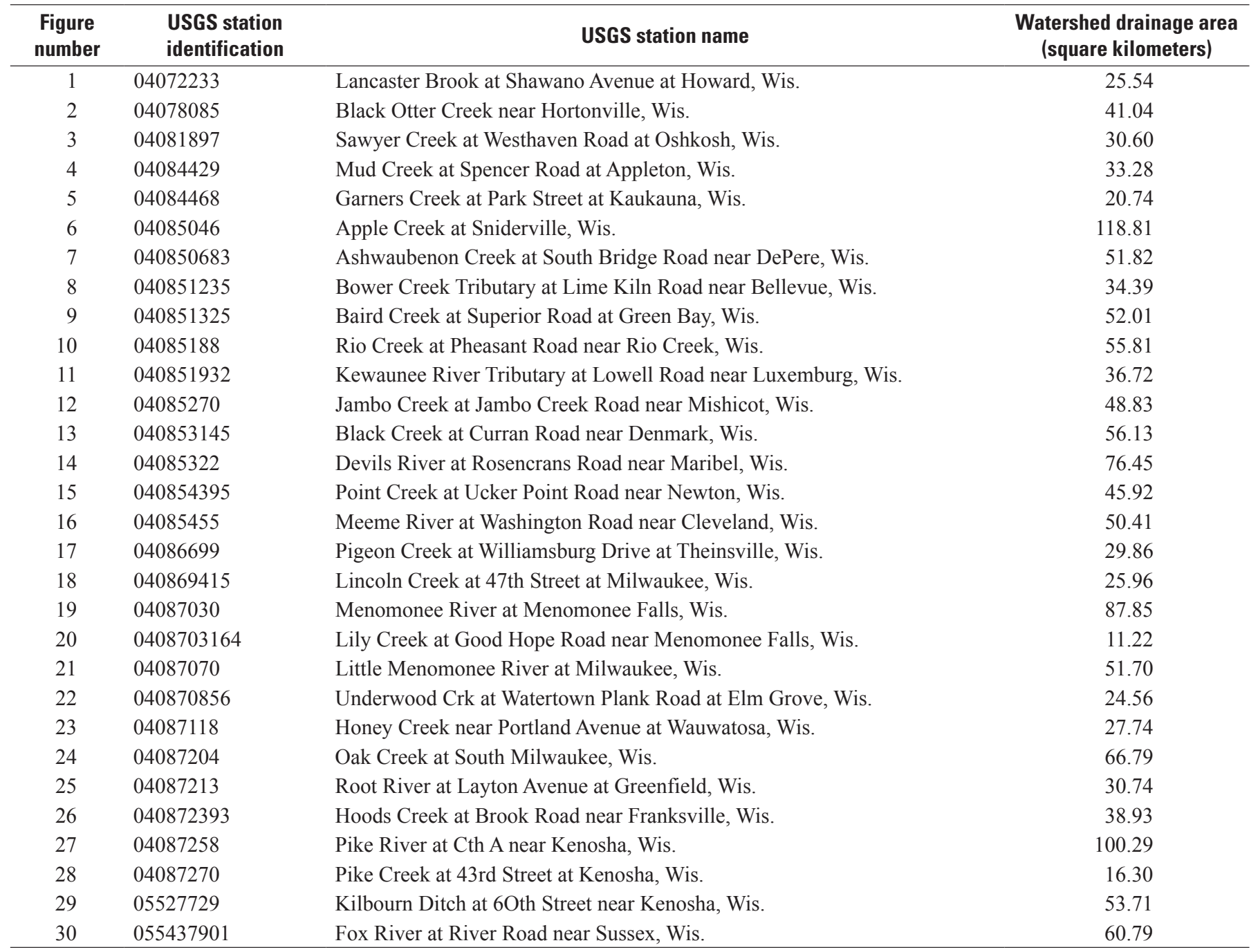




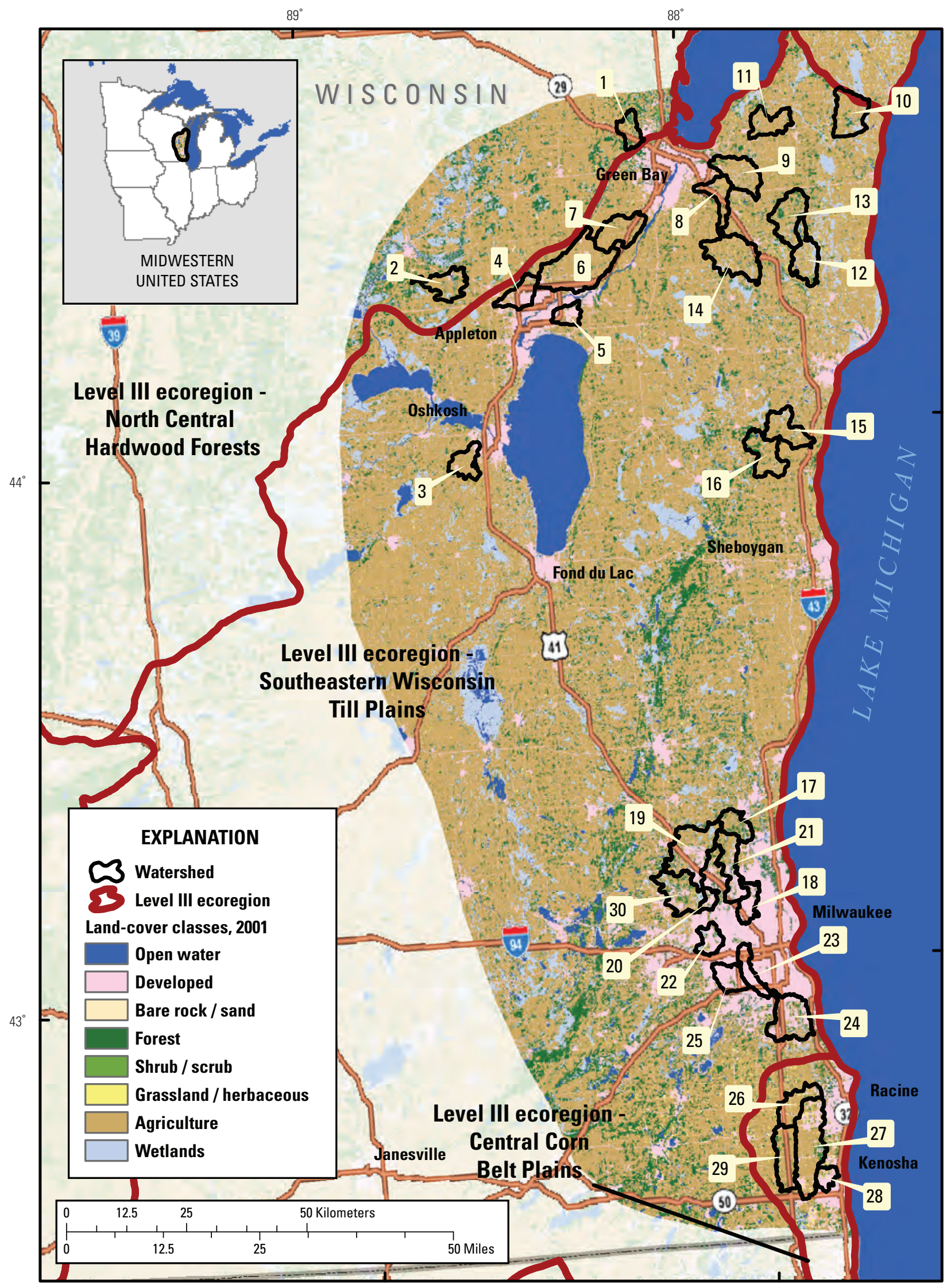

Figure 1-9. Locations of study watersheds in the Milwaukee, Wisconsin, metropolitan area. 

Manuscript was approved on April 10, 2012.

\section{Prepared by:}

USGS Scientific Publishing Network

Raleigh Publishing Service Center

3916 Sunset Ridge Road

Raleigh, NC 27607

For additional information regarding this publication, contact: Silvia Terziotti

U.S. Geological Survey

3916 Sunset Ridge Road

Raleigh, NC 27607

email: seterzio@usgs.gov

Or visit the NAWQA EUSE Web site at: http://water.usgs.gov/nawqa/urban/ 


$$
\text { 奇 }
$$

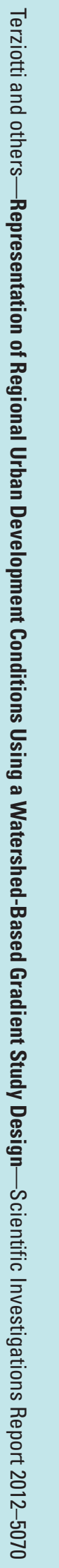

